STATE OF ALASKA

DEPARTMENT OF NATURAL RESOURCES

Alaska Geologic Materials Center Data Report No. 355

No. 355: Bristol Bay Native Corp Iron, Titanium, Platinum Kemuk Mountain Prospect; Data on 8,338' of Core from 14 Holes, Nushagak Basin in Southwest Alaska, Dillingham District, Alaska

Received September, 2008

$\mathrm{CD}$ available upon request from $\underline{\mathrm{DGGS}}$ or the $\underline{\mathrm{AOGCC}}$

All data reports may be downloaded free of charge from the DGGS website. 


\section{Kemuk Iron Titanuium-Platinum Prospect, Nushagax Basin, Southwest Alaska Inventory of Data on CD of 8338' of Core Donated to the Alaska GMC}

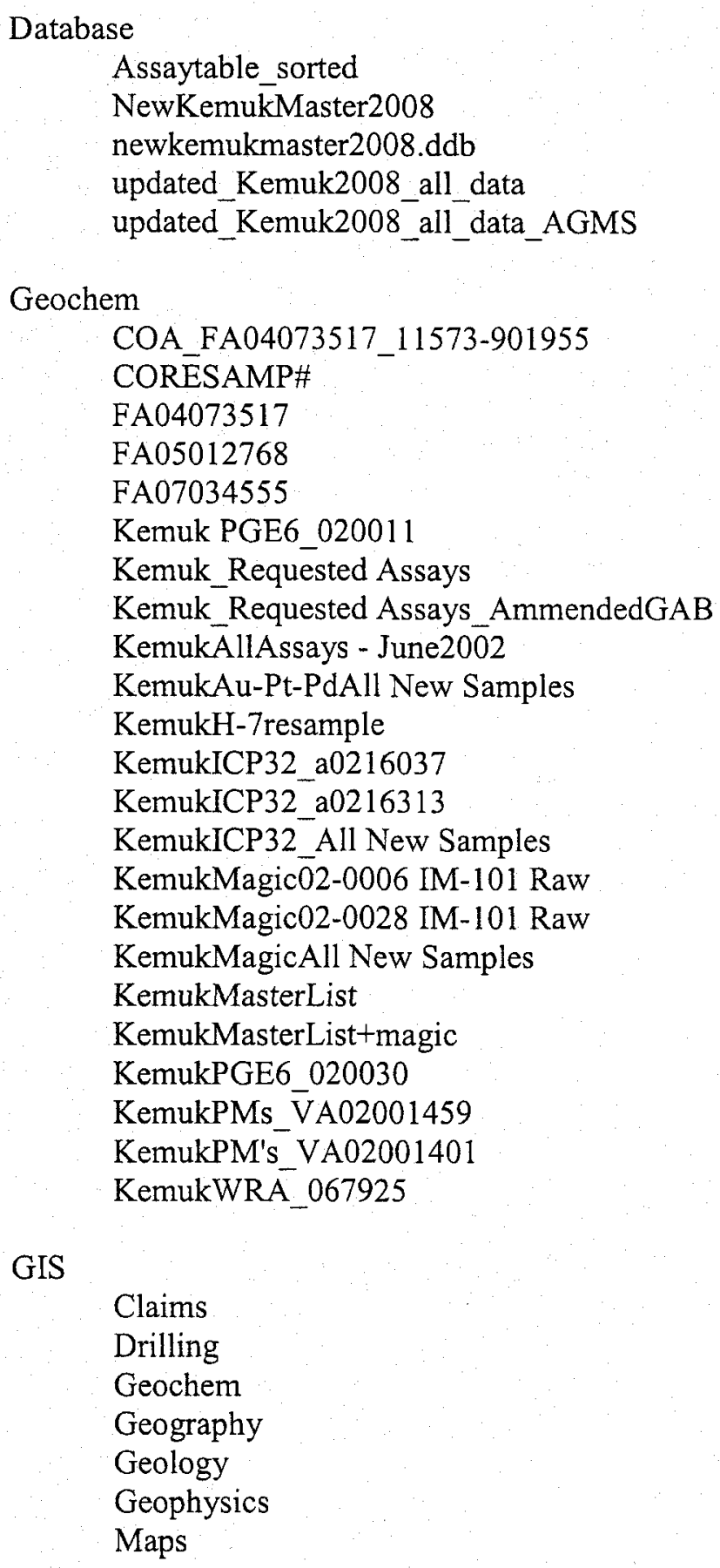


Kemuk Iron Titanuium-Platinum Prospect, Nushagax Basin, Southwest Alaska

Inventory of Data on CD of 8338' of Core Donated to the Alaska GMC (page 2)

Reports
Kemuk Pet Reports
scans
1 H-2 200
$2 \mathrm{H}-2269$
$3 \mathrm{H}-2320$
$4 \mathrm{H}-2355$
$5 \mathrm{H}-3656$
$6 \mathrm{H}-3663$
$7 \mathrm{H}-3782$
$8 \mathrm{H}-3983$
$9 \mathrm{H}-4322$
$10 \mathrm{H}-4361$
$11 \mathrm{H}-6291$
$12 \mathrm{H}-6291$
$13 \mathrm{H}-8228.5$
$14 \mathrm{H}-8387$
$15 \mathrm{H}-8572$
$16 \mathrm{H}-9273.5$
$17 \mathrm{H}-9300.5$
$18 \mathrm{H}-9860$
$19 \mathrm{H}-91267$
$20 \mathrm{H}-91378$
$21 \mathrm{H}-91977$
$22 \mathrm{H}-10445.6$
$23 \mathrm{H}-12375$
$24 \mathrm{H}-12585$
$25 \mathrm{H}-1499$
$26 \mathrm{H}-14338$
$27 \mathrm{H}-15578.5$
$28 \mathrm{H}-15630$
$29 \mathrm{H}-16303$
$30 \mathrm{H}-16559$
KemukWR

Sections

$\mathrm{Cu}$ eastwest

PGE_eastwest 
Drilling - The E. J. Longyear Company of Minneapolls, Minnesota, was again contracted to conduct the core drilling program. Longyear was responsible for furnishing two drill units and the personnel to operate them. In addition, an engineer-geologist was furnished to prepare the diamond drill core for analysis, complle the final assays and lithologic descriptions, and submit recomendations relative to the location of drill sites.

Longyear provided two hydraulic gasoline-powered rigs of its own design (see Plate III, Fig. 2). The smaller unt, the Juntor Straitline model, which had been beld over from the 1958 work, is capable of drilling to 1,200 feet. The Model 44 unit was designed for depths down to 3,000 feet. The Model $44 \mathrm{rig}$ was equipped with a wire-line core barrel which aided both core recovery and drilling progress.

Rock bits and drilling mud were used to drill through the glacial overburden. When ledge (bedrock beneath the fluvial-glacial f111) was encountered, casing was set, and a diamond core bit installed to core the bedrock. Fresh water replaced the drilling mud when cortng operations began.

The rigs operated on a 24 -hour-a-day, 7-day-a-week drilling schedule. Three 8-hour work shifts were used; each crew was comprised of a driller and a belper. Longrear provided one drill foreman to supervise the drilling personnel and to oversee the maintenance of the rigs.

\footnotetext{
Sample analysis - Core was subjected to a tbree-phase fleld

analysis: determination of magnetic polarity and intensity, visual examination, and measurement of specific gravity for estimation of magnetite content.
} 
Kemuk Drill Production (1959)

\begin{tabular}{|l|c|c|c|c|c|c|}
\hline \multicolumn{1}{|c|}{ Hole } & Depth & Overburden & Rig \# & Days Drilling & Move Days & Daily Production \\
\hline $\mathrm{H}-1$ & 57 & 57 & & & & \\
\hline $\mathrm{H}-2$ & 500 & 196 & & & & \\
\hline $\mathrm{H}-3$ & 1002 & 308 & & & & \\
\hline $\mathrm{H}-4$ & 500 & 292 & & & & \\
\hline $\mathrm{H}-5$ & 140 & 140 & & & & \\
\hline $\mathrm{H}-6$ & 821 & 278 & & & & \\
\hline $\mathrm{H}-7$ & 2000 & 138 & 1 & 22 & & 91 \\
\hline $\mathrm{H}-8$ & 577 & 222 & 2 & 17 & & 34 \\
\hline $\mathrm{H}-9$ & 2000 & 230 & 1 & 14 & 3 & 143 \\
\hline $\mathrm{H}-10$ & 532 & 200 & 2 & 8 & 3 & 67 \\
\hline $\mathrm{H}-11$ & 500 & 159 & 2 & 5 & 2 & 100 \\
\hline $\mathrm{H}-12$ & 600 & 254 & 2 & 8 & 2 & 75 \\
\hline $\mathrm{H}-13$ & 668 & 250 & 1 & 6 & 4 & 111 \\
\hline $\mathrm{H}-14$ & 500 & 91 & 2 & 12 & 4 & 42 \\
\hline $\mathrm{H}-15$ & 637 & 458 & 1 & 5 & 2 & 127 \\
\hline $\mathrm{H}-16$ & 601 & 256 & 2 & 9 & 2 & 67 \\
\hline $\mathrm{H}-17$ & 520 & 298 & 1 & 9 & 5 & 58 \\
\hline Total Hole & 12155 & 3827 & & Total Drill Days & Total Move days & Avg Footage/Day \\
\hline
\end{tabular}

Rig 1 thong 44

Rig 2 Junwistraitline 


\section{ALS Chemex}

AURORA LABORATORY SERVICES LTD.

212 Brookstank Ave, North Vancouver BC Canada V7J 2C1

Phone: 604-984-0221 Fax: 604-984-0218 Weksite: www.alschemex.com

\section{FAX DATA REPORT}

COMPANY : ALASKA EARTH SCIENCES

CONTACT : ATTN: BILL ELLIS

FAX NUMBER : 1-907-349-3557

\section{SENDER : DEAN}

NO OF PAGES : 7 INCL COVER

SUBJECT : Automated FAX data delivery

\section{DESCRIPTION :}

Results for workorder A0110008 - Project : KEMUK

62 samples received on 29-DEC-00 by our Vancouver office

This workorder has all data entered

FAX COPY ONLY - A certified copy will be sent through the mail

If there are any problems with this transmission, please call our office immediately at 6049840221

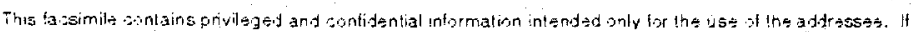




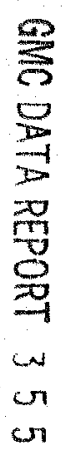

\section{ALS Chemex}

Chemex Labs, Inc.
Analytical Chemists - Geuchernsts " Registered Assayers
994 Glendale Ave., Unit 3,

$\begin{array}{rr}\text { Nevada, U.S.A. } & 88431 \\ \text { PHONE: } 775-356-5385 & \text { FAX: 775-355-0179 }\end{array}$

To: ALASKA EARTH SCIENCES

11401 OLIVE LANE

ANCHORAGE, ALASKA

99515. USA

Project: KEMU

Comments: ATTN: BILLL ELLIS
Page Number : 1-A

Tolalificases :2 muice No Da : L11000 P.O. Number Account KET

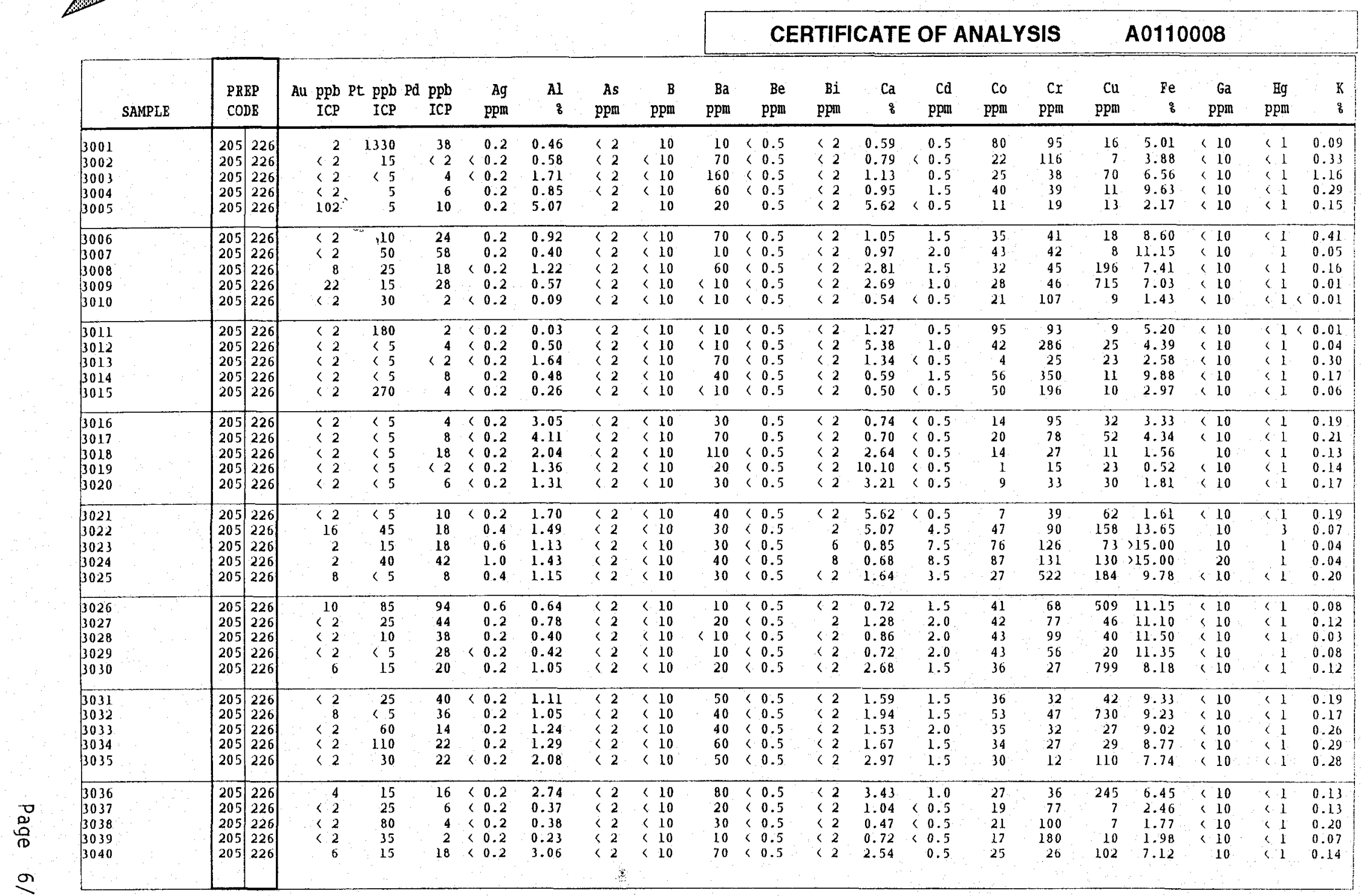




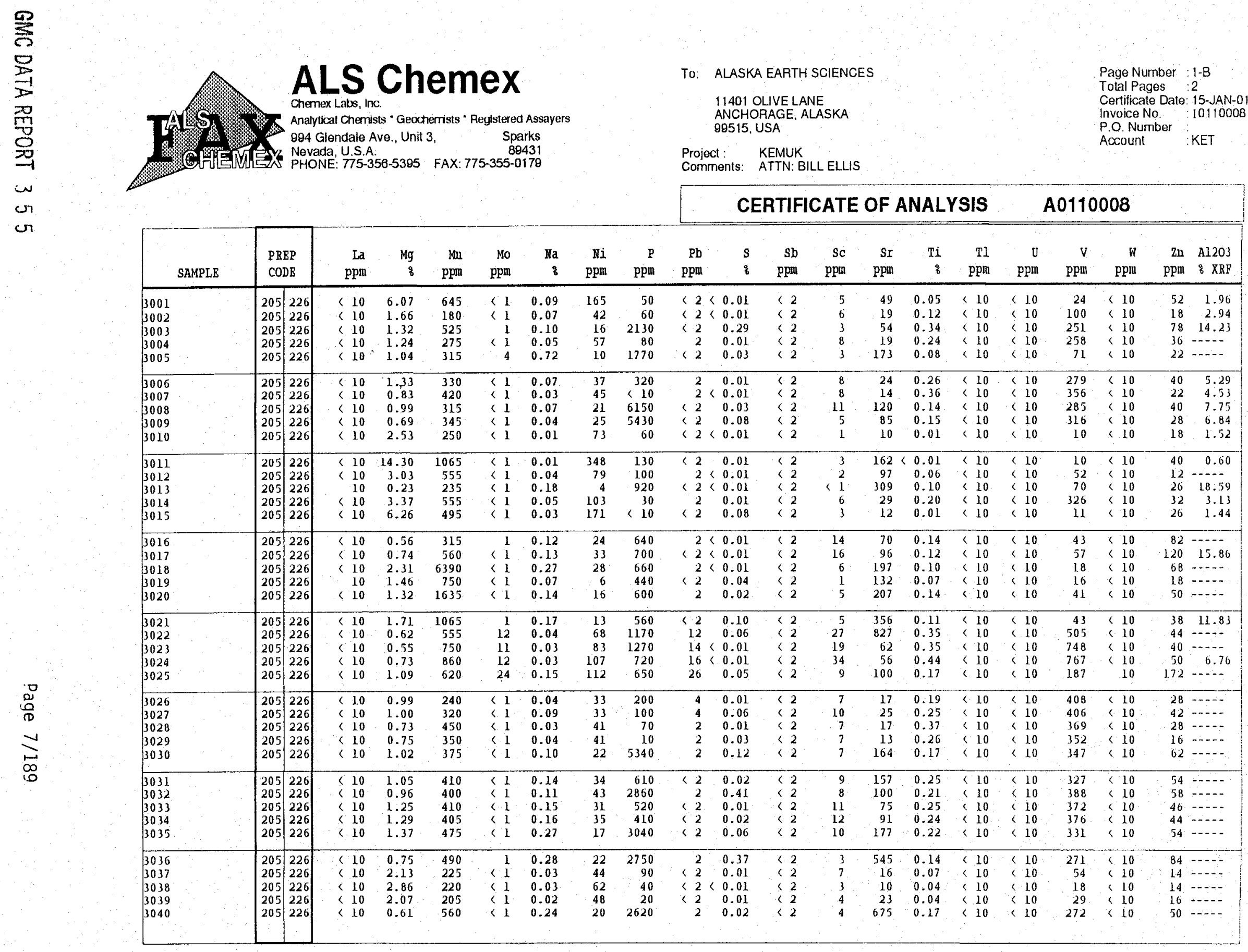




\section{ALS Chemex}

TASS

To: ALASKA EARTH SCIENCES

11401 OLIVE LANE

ANCHORAGE
99515, USA

Project: KEMUK

Comments: ATTN: BILL ELLIS
Page Number : i-C

Centificate Date: 15-JAN-0 Invoice No - 10110008 P. Number Account KET

\section{CERTIFICATE OF ANALYSIS A0110008}

\begin{tabular}{|c|c|c|c|c|c|c|c|c|c|c|c|c|c|c|c|c|c|c|c|c|}
\hline SAMPLE & $\begin{array}{l}\text { PRE } \\
\text { COD }\end{array}$ & IRP & $\begin{array}{r}\mathrm{CaO} \\
\& \quad \mathrm{XPF}\end{array}$ & $\begin{array}{l}\text { Cr203 } \\
8 \text { XRF }\end{array}$ & $\begin{array}{l}\text { Fe203 } \\
\text { \& XRP }\end{array}$ & $\begin{array}{r}\mathrm{K} 20 \\
8 \quad \mathrm{XRF}\end{array}$ & $\begin{array}{r}\text { Mg0 } \\
8 \quad \text { XRF }\end{array}$ & $\begin{array}{r}\mathrm{MnO} \\
\& \mathrm{XRF}\end{array}$ & $\begin{array}{r}\text { Na20 } \\
8 \text { XRF }\end{array}$ & $\begin{array}{r}\text { P205 } \\
8 \quad X R F\end{array}$ & $\begin{array}{r}5 i 02 \\
8 \text { XRF }\end{array}$ & $\begin{array}{r}\mathrm{Ti} 02 \\
\therefore \mathrm{XBF}\end{array}$ & $\begin{array}{r}\text { LOI } \\
\& \quad \mathrm{XRF}\end{array}$ & $\begin{array}{r}\text { TOTAL } \\
:\end{array}$ & $\begin{array}{r}\mathrm{Ba} \\
\mathrm{ppm}\end{array}$ & $\begin{array}{r}\mathrm{Rb} \\
\mathrm{ppm}\end{array}$ & $\begin{array}{r}\mathrm{Sr} \\
\mathrm{ppm}\end{array}$ & $\begin{array}{r}\mathrm{Nb} \\
\mathrm{ppm}\end{array}$ & $\begin{array}{r}\mathrm{zr} \\
\mathrm{ppm}\end{array}$ & $\begin{array}{r}Y \\
\text { ppm }\end{array}$ \\
\hline $\begin{array}{l}3001 \\
3002 \\
3003\end{array}$ & $\begin{array}{l}205 \\
205 \\
205\end{array}$ & $\begin{array}{l}226 \\
226 \\
226\end{array}$ & $\begin{array}{r}14.16 \\
20.52 \\
9.12\end{array}$ & $\begin{array}{l}0.02 \\
0.02 \\
<0.01\end{array}$ & $\begin{array}{l}11.09 \\
10.59 \\
13.04\end{array}$ & $\begin{array}{l}0.15 \\
0.49 \\
2.90\end{array}$ & $\begin{array}{r}19.17 \\
15.01 \\
5.20\end{array}$ & $\begin{array}{l}0.16 \\
0.12 \\
0.22\end{array}$ & $\begin{array}{l}0.22 \\
0.24 \\
3.24\end{array}$ & $\begin{array}{l}0.02 \\
0.04 \\
0.58\end{array}$ & $\begin{array}{l}46.81 \\
47.90 \\
47.79\end{array}$ & $\begin{array}{l}0.26 \\
0.60 \\
1.12\end{array}$ & $\begin{array}{l}5.57 \\
0.65 \\
0.82\end{array}$ & $\begin{array}{l}99.59 \\
99.12 \\
98.26\end{array}$ & $\begin{array}{r}40 \\
130 \\
630\end{array}$ & $\begin{array}{l}24 \\
34 \\
72\end{array}$ & $\begin{array}{r}86 \\
84 \\
1070\end{array}$ & $\begin{array}{r}4 \\
6 \\
10\end{array}$ & $\begin{array}{l}18 \\
24 \\
90\end{array}$ & $\begin{array}{r}8 \\
8 \\
24\end{array}$ \\
\hline 3004 & $\begin{array}{l}205 \\
205\end{array} \mid$ & $\begin{array}{l}226 \\
226\end{array}$ & - & 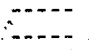 & 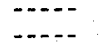 & 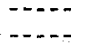 & 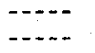 & $\cdots$ & & & 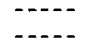 & & & & & & & & & \\
\hline $\begin{array}{l}3006 \\
3007 \\
3008 \\
3009 \\
3010\end{array}$ & \begin{tabular}{|l|}
205 \\
205 \\
205 \\
205 \\
205
\end{tabular} & $\begin{array}{l}226 \\
226 \\
226 \\
226 \\
226\end{array}$ & $\begin{array}{l}19.11 \\
19.32 \\
20.24 \\
22.34 \\
21.74\end{array}$ & $\begin{array}{l}0.01 \\
0.01 \\
0.01 \\
0.02 \\
0.07\end{array}$ & $\begin{array}{r}19.94 \\
23.61 \\
18.20 \\
18.88 \\
5.34\end{array}$ & $\begin{array}{l}0.64 \\
0.09 \\
0.40 \\
0.05 \\
0.04\end{array}$ & $\begin{array}{r}11.76 \\
11.16 \\
8.54 \\
9.39 \\
18.32\end{array}$ & $\begin{array}{l}0.17 \\
0.15 \\
0.17 \\
0.20 \\
0.10\end{array}$ & $\begin{array}{l}0.27 \\
0.05 \\
0.21 \\
0.19 \\
0.14\end{array}$ & $\begin{array}{l}0.10 \\
0.01 \\
1.64 \\
1.45 \\
0.03\end{array}$ & $\begin{array}{l}40.71 \\
39.43 \\
38.76 \\
38.39 \\
51.21\end{array}$ & $\begin{array}{l}1.54 \\
1.61 \\
1.76 \\
1.83 \\
0.22\end{array}$ & $\begin{array}{r}0.21 \\
-0.30 \\
1.93 \\
-0.12 \\
1.02\end{array}$ & $\begin{array}{l}99.75 \\
99.66 \\
99.60 \\
99.46 \\
99.75\end{array}$ & $\begin{array}{r}135 \\
50 \\
150 \\
25 \\
15\end{array}$ & $\begin{array}{l}38 \\
26 \\
30 \\
24 \\
14\end{array}$ & $\begin{array}{r}96 \\
66 \\
214 \\
148 \\
76\end{array}$ & $\begin{array}{l}6 \\
6 \\
4 \\
4 \\
6\end{array}$ & $\begin{array}{l}30 \\
24 \\
72 \\
60 \\
12\end{array}$ & $\begin{array}{r}10 \\
8 \\
18 \\
16 \\
8\end{array}$ \\
\hline $\begin{array}{l}013 \\
014 \\
015 \\
015\end{array}$ & $\begin{array}{l}205 \\
205 \\
205 \\
205 \\
205\end{array}$ & $\begin{array}{l}226 \\
226 \\
226 \\
226 \\
226\end{array}$ & \begin{tabular}{r}
7.96 \\
\hdashline 6.40 \\
6.40 \\
17.14
\end{tabular} & \begin{tabular}{c}
0.06 \\
\hdashline 0.01 \\
0.04 \\
0.13
\end{tabular} & $\begin{array}{r}10.99 \\
5.22 \\
21.88 \\
7.19\end{array}$ & \begin{tabular}{c}
0.04 \\
\hdashline 3.67 \\
0.27 \\
0.10
\end{tabular} & $\begin{array}{c}33.23 \\
1.68 \\
15.21 \\
21.20\end{array}$ & $\begin{array}{l}0.21 \\
0.13 \\
0.19 \\
0.13\end{array}$ & $\begin{array}{c}0.01 \\
-4.41 \\
0.20 \\
0.18\end{array}$ & $\begin{array}{c}0.05 \\
0.23 \\
0.03 \\
0.02\end{array}$ & \begin{tabular}{c}
41.04 \\
\hdashline 55.11 \\
40.16 \\
47.32
\end{tabular} & $\begin{array}{c}0.09 \\
0 . .57 \\
0.57 \\
0.16\end{array}$ & $\begin{array}{c}5.59 \\
-.-21 \\
2.21 \\
1.12 \\
3.54\end{array}$ & $\begin{array}{r}99.86 \\
998.22 \\
99.62 \\
98.55\end{array}$ & $\begin{array}{r}15 \\
1080 \\
100 \\
35\end{array}$ & $\begin{array}{l}20 \\
70 \\
28 \\
20\end{array}$ & $\begin{array}{r}204 \\
1110 \\
96 \\
62\end{array}$ & $\begin{array}{r}6 \\
-6 \\
18 \\
6 \\
4\end{array}$ & $\begin{array}{r}15 \\
-- \\
153 \\
18 \\
12\end{array}$ & $\begin{array}{r}24 \\
8 \\
4\end{array}$ \\
\hline $\begin{array}{c}3016 \\
3017 \\
3018 \\
3019 \\
3020\end{array}$ & $\begin{array}{l}205 \\
205 \\
205 \\
205 \\
205\end{array}$ & \begin{tabular}{|l|}
226 \\
226 \\
226 \\
226 \\
226
\end{tabular} & 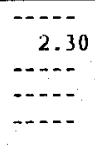 & $\begin{array}{c}0.01 \\
0\end{array}$ & \begin{tabular}{c}
0.05 \\
7.05 \\
\hdashline- \\
\hdashline$-\cdots$
\end{tabular} & $\begin{array}{c}1.47 \\
\cdots\end{array}$ & $\begin{array}{c}1.30 \\
\cdots \\
\cdots\end{array}$ & 0.10 & $\begin{array}{c}1.61 \\
\cdots \\
\cdots\end{array}$ & $\begin{array}{c}0.18 \\
\cdots \\
\cdots \cdots\end{array}$ & 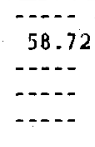 & $\begin{array}{c}0.82 \\
\cdots \\
\cdots\end{array}$ & 10.12 & $\begin{array}{c}99.53 \\
\cdots \\
\cdots\end{array}$ & 385 & $\begin{array}{l}42 \\
-- \\
--\end{array}$ & $\begin{array}{r}354 \\
354 \\
\cdots\end{array}$ & $\begin{array}{l}-- \\
10 \\
\therefore\end{array}$ & $\begin{array}{c}-144 \\
\cdots\end{array}$ & $\begin{array}{l}24 \\
- \\
-\end{array}$ \\
\hline $\begin{array}{l}3021 \\
3022 \\
3023 \\
3024 \\
3025\end{array}$ & \begin{tabular}{|l|}
205 \\
205 \\
205 \\
205 \\
205 \\
\end{tabular} & \begin{tabular}{|l|}
226 \\
226 \\
226 \\
226 \\
226
\end{tabular} & $\begin{array}{c}18.18 \\
9.86 \\
-9\end{array}$ & \begin{tabular}{c}
0.01 \\
\hdashline 0.01 \\
\hdashline-0
\end{tabular} & \begin{tabular}{c}
5.63 \\
\hdashline$\ldots .-$ \\
46.53 \\
$\cdots$
\end{tabular} & \begin{tabular}{c}
1.72 \\
0.19 \\
\hdashline
\end{tabular} & \begin{tabular}{c}
4.26 \\
\hdashline 5.74 \\
\hdashline-
\end{tabular} & $\begin{array}{c}0.33 \\
0.28 \\
0 .\end{array}$ & \begin{tabular}{c}
1.43 \\
\hdashline-0 \\
0.06 \\
\hdashline--
\end{tabular} & \begin{tabular}{c}
0.14 \\
\hdashline-1 \\
0.21 \\
$-\cdots$
\end{tabular} & $\begin{array}{c}49.93 \\
23.51 \\
\ldots . .\end{array}$ & $\begin{array}{r}2.78 \\
-\end{array}$ & \begin{tabular}{c}
5.49 \\
\hdashline 3.49 \\
.-
\end{tabular} & \begin{tabular}{c}
99.50 \\
999.41 \\
\hdashline-
\end{tabular} & $\begin{array}{r}10 \\
0\end{array}$ & 38 & $\begin{array}{c}518 \\
1.88 \\
\cdots\end{array}$ & 4 & $\begin{array}{l}87 \\
-- \\
-4 \\
42\end{array}$ & 20 \\
\hline $\begin{array}{l}3026 \\
3027 \\
3028 \\
3029 \\
3030\end{array}$ & $\begin{array}{l}205 \\
205 \\
205 \\
205 \\
205\end{array}$ & $\begin{array}{l}226 \\
226 \\
226 \\
226 \\
226\end{array}$ & \begin{tabular}{c}
$\cdots$ \\
$\cdots$ \\
$\cdots \cdots$ \\
\hdashline$\cdots$ \\
$\cdots \cdots$
\end{tabular} & $\begin{array}{l}\cdots \cdots \\
\cdots-\cdots \\
\cdots-\cdots \\
\cdots \cdots\end{array}$ & $\begin{array}{l}\cdots \\
\cdots \\
\cdots \\
\cdots\end{array}$ & 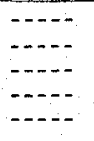 & \begin{tabular}{l}
$\cdots$ \\
\hdashline$\cdots$ \\
\hdashline$\cdots$
\end{tabular} & $\begin{array}{l}-\cdots \\
\cdots \\
-\cdots \\
-\cdots-\end{array}$ & $\begin{array}{l}-\cdots \\
-\cdots \\
-\cdots- \\
-\cdots \\
\cdots-\end{array}$ & $\begin{array}{l}\cdots- \\
\cdots-\cdots \\
\cdots \cdots \\
\cdots-\cdots\end{array}$ & \begin{tabular}{l}
$\cdots-1$ \\
\hdashline$-\cdots$ \\
$-\cdots-$ \\
$-\cdots-$
\end{tabular} & \begin{tabular}{l}
$\cdots$ \\
$\cdots \cdots$ \\
$\cdots \cdots$ \\
\hdashline$-\cdots$ \\
\hdashline$-\cdots$
\end{tabular} & 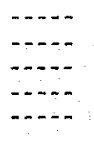 & \begin{tabular}{l}
$\cdots \cdots$ \\
$\cdots \cdots$ \\
\hdashline$-\cdots$ \\
$\cdots$
\end{tabular} & 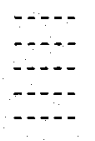 & $\begin{array}{l}-\cdots \\
--1 .-\end{array}$ & $\cdots$ & & & \\
\hline \begin{tabular}{|l}
3031 \\
3032 \\
3033 \\
3034 \\
3035
\end{tabular} & \begin{tabular}{|l|}
205 \\
205 \\
205 \\
205 \\
205
\end{tabular} & \begin{tabular}{|l|}
226 \\
226 \\
226 \\
226 \\
226
\end{tabular} & $\begin{array}{c}\cdots \cdots \\
\cdots \cdots \\
\cdots \cdots \\
\cdots \cdots\end{array}$ & $\begin{array}{l}\cdots- \\
\cdots- \\
\cdots \cdots\end{array}$ & $\begin{array}{l}\cdots \\
-\ldots \\
-\ldots\end{array}$ & \begin{tabular}{l}
$-\cdots$ \\
$-\cdots$ \\
\hdashline-1
\end{tabular} & $\begin{array}{l}\ldots \\
\cdots \cdots \\
\cdots \cdots \\
\cdots\end{array}$ & $\begin{array}{l}\cdots \cdots \\
\cdots \\
\cdots \\
-\cdots \\
\cdots \cdots\end{array}$ & $\begin{array}{l}\cdots-\cdots \\
\cdots-- \\
\cdots-\cdots \\
-\cdots\end{array}$ & $\begin{array}{l}\cdots \\
\cdots \\
\cdots\end{array}$ & $\begin{array}{c}\cdots \\
\cdots \\
\cdots \cdots \\
\cdots \cdots\end{array}$ & $\begin{array}{l}\cdots \\
\cdots \\
\cdots \\
\cdots\end{array}$ & $\begin{array}{l}\cdots \cdots \\
\cdots \\
\cdots \\
\cdots\end{array}$ & - & $\begin{array}{l}\cdots \cdots \\
\cdots \\
-\cdots \\
-\cdots\end{array}$ & $\begin{array}{l}\cdots \\
\cdots \\
\cdots \\
\cdots\end{array}$ & 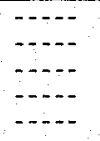 & 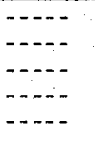 & , & $\therefore$ \\
\hline $\begin{array}{l}3036 \\
3037 \\
3038 \\
3039 \\
3040\end{array}$ & $\begin{array}{l}205 \\
205 \\
205\end{array}$ & $\begin{array}{l}226 \\
226 \\
226 \\
226 \\
226\end{array}$ & $\begin{array}{c}\cdots \\
\cdots \\
\cdots \\
\cdots\end{array}$ & $\begin{array}{l}\cdots \\
-\cdots \\
-\cdots \\
-\cdots\end{array}$ & $\begin{array}{c}\cdots \cdots \\
\cdots \cdots \\
\cdots \cdots \\
\cdots \cdots\end{array}$ & ב... & - & $\begin{array}{l}\cdots \\
\cdots \\
\cdots \\
\cdots-\cdots\end{array}$ & $\begin{array}{l}\cdots \cdots \\
\cdots \cdots \\
\cdots \cdots\end{array}$ & $\begin{array}{l}\cdots \\
\cdots \\
\cdots \\
\cdots \cdots \\
\cdots \cdots\end{array}$ & $\begin{array}{l}\ldots \\
\cdots \\
\cdots \\
\cdots \\
\cdots\end{array}$ & \begin{tabular}{l}
$\cdots \cdots$ \\
$\cdots \cdots$ \\
\hdashline$-\cdots$ \\
\hdashline$\cdots$
\end{tabular} & \begin{tabular}{l}
--- \\
$-\cdots$ \\
\hdashline$-\cdots$ \\
\hdashline$-\cdots$
\end{tabular} & $\begin{array}{l}-1- \\
\cdots \\
\cdots \\
\cdots\end{array}$ & $\begin{array}{l}\cdots \\
\cdots \\
\cdots\end{array}$ & $\begin{array}{l}\cdots- \\
\cdots \cdots \\
\cdots \cdots \\
\cdots \cdots\end{array}$ & $\begin{array}{l}-\cdots \\
\cdots \\
\cdots \cdots \\
\cdots-\end{array}$ & $\begin{array}{l}\ldots . . \\
\ldots y\end{array}$ & 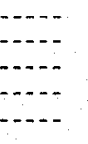 & \begin{tabular}{l}
$\cdots \cdots$ \\
$\cdots \cdots$ \\
\hdashline$-\cdots$
\end{tabular} \\
\hline
\end{tabular}




\section{ALS Chemex}

Analytical Chernists " Geocherrists ' Reglstered Assayers

994 Glendale Ave., Unit 3.

Sparks
89431

$\begin{array}{lr}\text { Nevada, U.S.A. } & 89431 \\ \text { PHONE: } 775-358-5395 & \text { FAX: 775-355-0178 }\end{array}$

TO: ALASKA EARTH SCIENCES

Page Number : 2-A

11401 OLIVE LANE

ANCHORAGE ALASKA

Certificate Date: 15-JAN-0 .

$\begin{array}{ll}\text { Project : } & \text { KEMUK } \\ \text { Comments: } & \text { ATTN: BILL ELLIS }\end{array}$

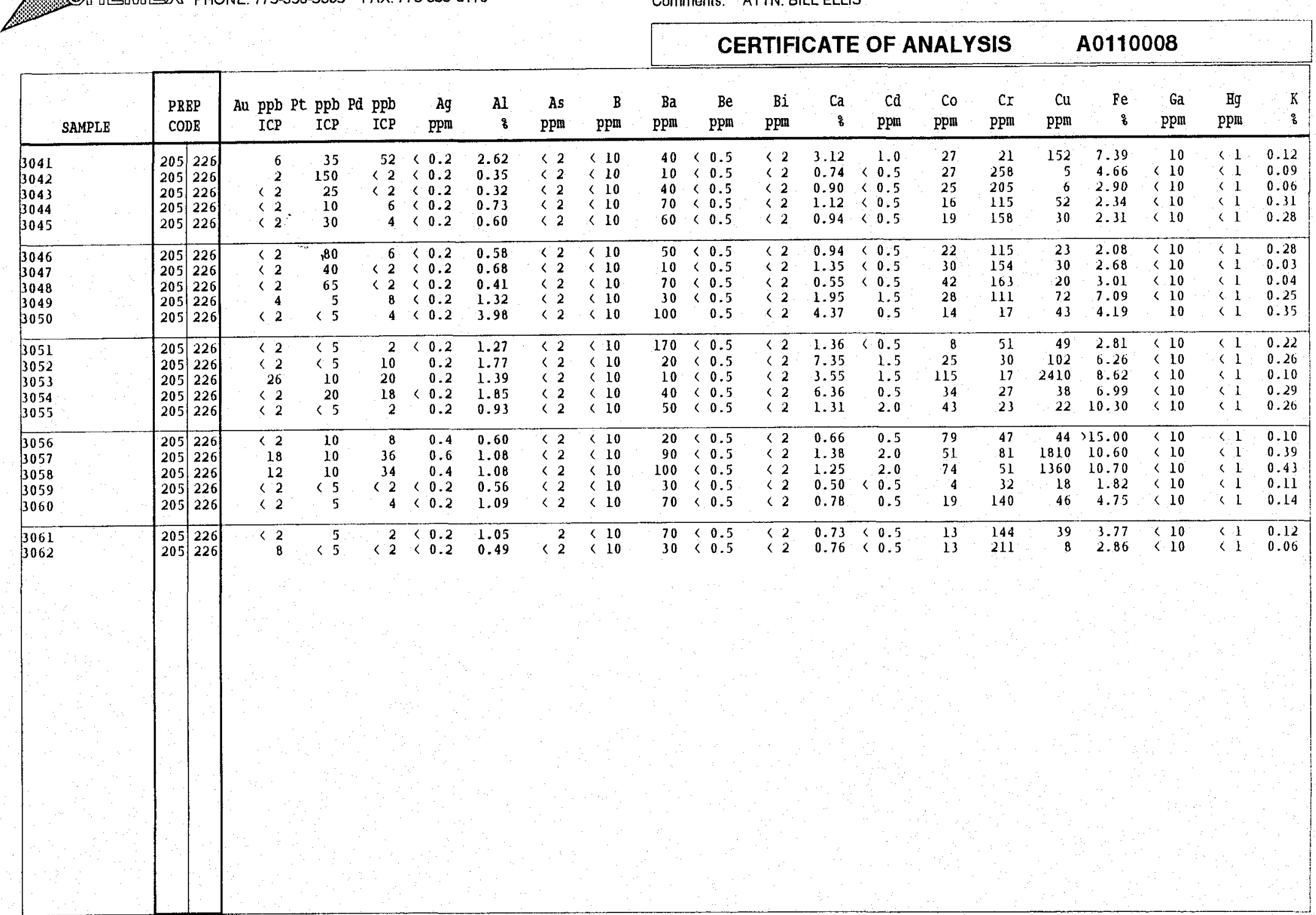




\section{ALS Chemex}

Analytical Chemists * Geochemlsts * Registered Assayers

To: ALASKA EARTH SCIENCES

Page Number : 2-B

11401 OLIVE LANE

Certificate Date: $15-J A N-0$

99515, USA

Invoica No Date: 0110008

994 Glendale Ave., Unit 3, Sparks

Project

KEMUK

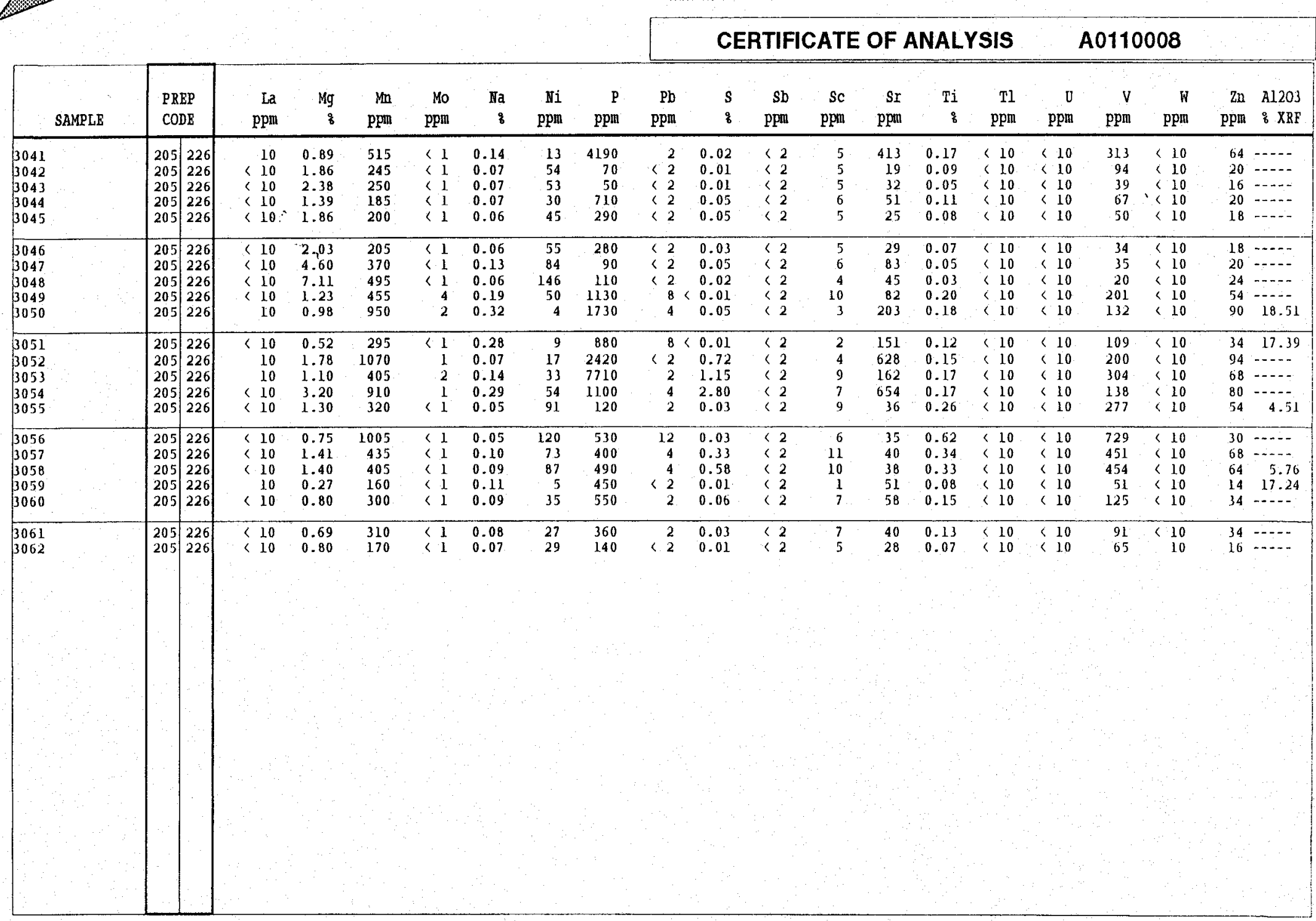




\section{ALS Chemex}

$7410 \%$ Analytical Chemists * Geocherrists * Registered Assayers

TO: ALASKA EARTH SCIENCES

11401 OLIVE LANE

AGE, ALASKA

89515, USA

Project: KEMUK

Comments: ATTN: BILL ELLIS
Page Number :2-C

Certificate Date: 15-JAN-01

Invoice No. : 10110008

Invoice No.

Aocount KET

\begin{tabular}{|c|c|c|c|c|c|c|c|c|c|c|c|c|c|c|c|c|c|c|c|c|}
\hline & & & & & & & & & & & \multicolumn{6}{|c|}{ CERTIFICATE OF ANALYSIS } & \multicolumn{3}{|c|}{ A0110008 } & \multirow[b]{2}{*}{$\begin{array}{r}\mathrm{Y} \\
\text { ppm }\end{array}$} \\
\hline SAMPLE & \multicolumn{2}{|c|}{$\begin{array}{l}\text { PREP } \\
\text { CODE }\end{array}$} & $\begin{array}{r}\mathrm{CaO} \\
8 \mathrm{XRF}\end{array}$ & $\begin{array}{l}\text { Cr203 } \\
8 \text { XRF }\end{array}$ & $\begin{array}{l}\mathrm{Fe} 203 \\
\& \mathrm{XRP}\end{array}$ & $\begin{array}{r}\mathrm{K} 20 \\
8 \mathrm{XRP}\end{array}$ & $\begin{array}{r}M g O \\
\& \quad X R P\end{array}$ & $\begin{array}{r}\text { Mno } \\
\& \text { XRF }\end{array}$ & $\begin{array}{r}\text { Ta20 } \\
\& \quad \mathrm{XRF}\end{array}$ & $\begin{array}{r}\text { P205 } \\
\& \quad X R F\end{array}$ & $\begin{array}{r}\mathrm{SiO2} \\
8 \mathrm{XRF}\end{array}$ & $\begin{array}{r}\text { TiO2 } \\
\& \quad \mathrm{XRP} \\
\end{array}$ & $\begin{array}{r}\text { LOI } \\
\& \mathrm{XRF} \\
\end{array}$ & $\begin{array}{r}\text { TOTAL } \\
8\end{array}$ & $\begin{array}{r}\text { Ba } \\
\text { ppin }\end{array}$ & $\begin{array}{r}\mathrm{Rb} \\
\mathrm{ppm}\end{array}$ & $\begin{array}{r}\text { sx } \\
\text { ppm }\end{array}$ & $\begin{array}{r}\mathrm{Mb} \\
\mathrm{ppm}\end{array}$ & $\begin{array}{r}\text { Zr } \\
\text { ppm }\end{array}$ & \\
\hline $\begin{array}{l}3041 \\
3042 \\
3043 \\
3044 \\
3045\end{array}$ & $\mid \begin{array}{l}205 \\
205 \\
205 \\
205 \\
205\end{array}$ & $\begin{array}{l}226 \\
226 \\
226 \\
226 \\
226\end{array}$ & $\begin{array}{l}\cdots \\
\cdots \\
\cdots \cdots \\
\cdots \cdots\end{array}$ & $\begin{array}{l}\cdots \\
\cdots \\
\cdots \cdots\end{array}$ & 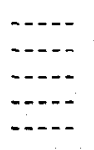 & 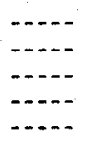 & 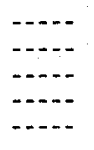 & 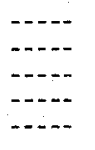 & $\begin{array}{l}\cdots \cdots \\
\cdots \cdots \\
\cdots \cdots \\
\cdots \cdots \\
\cdots-\cdots\end{array}$ & $\begin{array}{c}\cdots \\
\cdots \\
\cdots \cdots \\
\cdots \cdots \\
\cdots \cdots\end{array}$ & 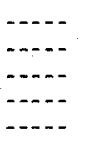 & $\begin{array}{l}-\cdots \\
-\cdots- \\
-\cdots- \\
-\cdots- \\
-\cdots-\end{array}$ & $\begin{array}{l}\cdots \cdots \\
\cdots \cdots \\
\cdots \cdots \\
\cdots \cdots\end{array}$ & 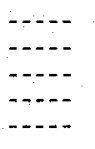 & \begin{tabular}{l}
$\cdots+\cdots$ \\
$\cdots-\cdots$ \\
\hdashline$-\cdots$ \\
\hdashline$-\cdots$
\end{tabular} & 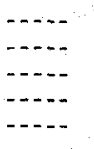 & 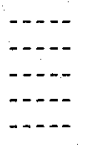 & - & - & $\begin{array}{l}\cdots \\
\cdots \\
\cdots- \\
\cdots\end{array}$ \\
\hline \begin{tabular}{|l}
3046 \\
3047 \\
3048 \\
3049 \\
3050
\end{tabular} & \begin{tabular}{|l|}
205 \\
205 \\
205 \\
205 \\
205
\end{tabular} & $\begin{array}{l}226 \\
226 \\
226 \\
226 \\
226\end{array}$ & \begin{tabular}{c}
$\ldots$ \\
\hdashline 10.96
\end{tabular} & \begin{tabular}{l}
0. \\
\hdashline 01 \\
\hdashline 0.0
\end{tabular} & \begin{tabular}{l}
0. \\
\hdashline .90 \\
\hdashline
\end{tabular} & \begin{tabular}{c}
$\cdots \cdot-$ \\
$\cdots \cdots$ \\
\hdashline-1. \\
\hdashline 1.20
\end{tabular} & \begin{tabular}{c}
$-\cdots$ \\
\hdashline$-\cdots$ \\
\hdashline$-\cdots$ \\
2.68
\end{tabular} & 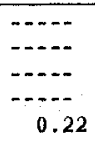 & $\begin{array}{c}4.18 \\
4.18\end{array}$ & $\begin{array}{c}\cdots \\
0.46\end{array}$ & $\begin{array}{c}--1 . \\
\cdots-1 \\
-1.9 \\
47.93\end{array}$ & $\begin{array}{c}0.90 \\
\cdots \\
\cdots\end{array}$ & $\begin{array}{c} \\
2.45 \\
\end{array}$ & \begin{tabular}{c}
$\ldots$ \\
90.39 \\
\hdashline
\end{tabular} & $\begin{array}{l}305 \\
30\end{array}$ & $\begin{array}{r}34 \\
\cdots\end{array}$ & $\begin{array}{l}\ldots \\
\cdots \\
\cdots \\
\cdots\end{array}$ & $\begin{array}{c}0 \\
14\end{array}$ & 111 & $\begin{array}{c}\cdots \\
\cdots \\
28\end{array}$ \\
\hline $\begin{array}{l}3051 \\
3052 \\
3053 \\
3054 \\
3055\end{array}$ & \begin{tabular}{|l|}
205 \\
205 \\
205 \\
205 \\
205
\end{tabular} & \begin{tabular}{l|}
226 \\
226 \\
226 \\
226 \\
226
\end{tabular} & \begin{tabular}{c}
4.56 \\
\hdashline 19.40 \\
19. \\
\end{tabular} & \begin{tabular}{c}
0.01 \\
00.01 \\
\hdashline 0.0
\end{tabular} & \begin{tabular}{r}
5.35 \\
\hdashline 20.76 \\
\hdashline-1. \\
\end{tabular} & $\begin{array}{c}2.64 \\
\ldots .6 \\
0.36\end{array}$ & \begin{tabular}{c}
1.91 \\
\hdashline 11.67 \\
\hdashline 1.2 \\
\end{tabular} & $\begin{array}{c}0.10 \\
0.14\end{array}$ & $\begin{array}{c}6.54 \\
0.19\end{array}$ & \begin{tabular}{c}
0.23 \\
\hdashline 0.06 \\
\end{tabular} & $\begin{array}{c}58.01 \\
-- \\
41.07\end{array}$ & \begin{tabular}{c}
0.54 \\
\hdashline \\
1.27
\end{tabular} & $\begin{array}{c}1.49 \\
0.39 \\
0 .\end{array}$ & \begin{tabular}{c}
98.77 \\
\hdashline 9 \\
99.82
\end{tabular} & \begin{tabular}{c}
1025 \\
\hdashline- \\
100
\end{tabular} & $\begin{array}{c}44 \\
\cdots \\
\cdots\end{array}$ & $\begin{array}{c}1035 \\
118\end{array}$ & $\begin{array}{c}10 \\
6\end{array}$ & \begin{tabular}{c}
9.9 \\
\hdashline- \\
27
\end{tabular} & $\begin{array}{c}16 \\
10\end{array}$ \\
\hline $\begin{array}{l}3056 \\
3057 \\
3058 \\
3059 \\
3060\end{array}$ & \begin{tabular}{|l|}
205 \\
205 \\
205 \\
205 \\
205
\end{tabular} & \begin{tabular}{l|}
226 \\
226 \\
226 \\
226 \\
226 \\
\end{tabular} & $\begin{array}{c}17.78 \\
2.78 \\
\cdots\end{array}$ & $\begin{array}{l}0.01 \\
0.01 \\
0\end{array}$ & $\begin{array}{r}23.68 \\
3.28 \\
\hdashline\end{array}$ & $\begin{array}{c}0 . . . \\
\cdots \cdots \\
0.65 \\
4.81 \\
\cdots\end{array}$ & $\begin{array}{r}10.62 \\
1.00 \\
0\end{array}$ & $\begin{array}{c}0.21 \\
0.07 \\
\cdots\end{array}$ & $\begin{array}{c}0.27 \\
4.81 \\
-\end{array}$ & $\begin{array}{c}0.14 \\
0.12 \\
\ldots \ldots\end{array}$ & $\begin{array}{c}\cdots . . . \\
38.44 \\
64.34 \\
\cdots \cdots\end{array}$ & $\begin{array}{l}1.90 \\
0.38 \\
-\end{array}$ & $\begin{array}{r}0.24 \\
0.67 \\
\cdots\end{array}$ & $\begin{array}{r}99.69 \\
99.50 \\
\end{array}$ & $\begin{array}{r}175 \\
595 \\
-\end{array}$ & $\begin{array}{r}44 \\
124 \\
\hdashline-. .0\end{array}$ & $\begin{array}{r}106 \\
446\end{array}$ & $\begin{array}{r}2 \\
24 \\
24\end{array}$ & $\begin{array}{r}30 \\
192 \\
-\end{array}$ & $\begin{array}{l}12 \\
26 \\
\cdots\end{array}$ \\
\hline $\begin{array}{l}3061 \\
3062\end{array}$ & $\begin{array}{l}205 \\
205\end{array}$ & \begin{tabular}{|l|}
226 \\
226
\end{tabular} & 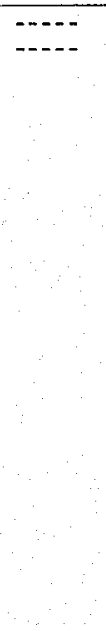 & $\cdots$ & 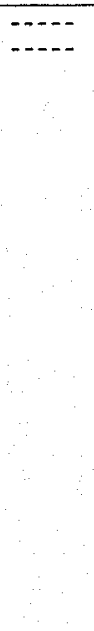 & $\cdots$ & (n... & $\bar{c}$ & $\cdots$ & $\cdots$ & - & $\cdots$ & $\ldots$ & $\cdots$ & $\cdots$ & - & $\cdots$ & $\cdots$ & $\cdots$ & $\cdots$ \\
\hline
\end{tabular}




\begin{tabular}{|c|c|c|c|c|c|}
\hline Hole & Depth & Overburden & \# samples-footage & Mineralization & Comments \\
\hline $\mathrm{H}-1$ & 57 & 57 & 0 & $?$ & Lost Hole \\
\hline $\mathrm{H}-2$ & 500 & 196 & $15-67.5^{2}$ & 5 samples $>100 \mathrm{ppb} \mathrm{Pt}$ high $1330 \mathrm{ppb} 4-+5 \% \mathrm{Mg}$ & Ulitramafic to $-350^{\prime}$ then Clinopyroxenite to $\mathrm{EOH}$ \\
\hline $\mathrm{H}-3$ & 1002 & 308 & 14-47" & High $108 \mathrm{ppb} \mathrm{Pt}+\mathrm{Pd}$ also high $102 \mathrm{ppb} \mathrm{Au}$ & Magnetite Pyroxenite some cumulate layering \\
\hline $\mathrm{H}-4$ & 500 & 292 & 4-26' & $715 \mathrm{ppm} \mathrm{Cu}+125$ ppb Pt+Pd Highest $7860 \mathrm{ppm} P$ & Fine-grained Pyroxenite \\
\hline $\mathrm{H}-5$ & 140 & 140 & 0 & ? & Lost Hole \\
\hline H.6 & 821 & 278 & $23-119^{\prime}$ & 4 samples $>50 \mathrm{ppb} \mathrm{Pt}+\mathrm{Pd}$, high $270 \mathrm{ppb} \mathrm{Pt}, 8-+5 \% \mathrm{Mg}$ & Magnetite Clinopyroxinite, Wehr-Cpxt $\mathrm{Brx}$ and Peridotite cut by Monzonite \\
\hline $\mathrm{H}-7$ & 2000 & 138 & 0 & not sampled & Magnetite Pyroxenite cut by Andesite dikes \\
\hline $\mathrm{H}-8$ & 577 & 222 & $13-67.5^{\prime}$ & 7 samples $>50 \mathrm{ppb} \mathrm{Pt}+\mathrm{Pd}$ high $179 \mathrm{ppb} ; 10>10 \% \mathrm{Fe}$ & Magnetite Pyroxenite and Gabbro some K-spar veins \\
\hline $\mathrm{H}-9$ & 2000 & 230 & $27-93.5^{\prime}$ & $\begin{array}{l}6 \text { samples }>50 \mathrm{ppb} \mathrm{Pt}+\mathrm{Pd} \text { high } 245 \mathrm{ppb} \text { highest Cu } 5 \\
\text { from } 700-2400 \mathrm{ppm} \& \mathrm{P} \text { to } 7710 \mathrm{ppm}, 10>10 \% \mathrm{fe}\end{array}$ & Gabbro and Magnetite Pyroxenite local sulfides $>5 \% \mathrm{~K}$-spar veins \\
\hline $\mathrm{H}-10$ & 532 & 200 & $15-60.5$ & 7 samples $>50 \mathrm{ppb} \mathrm{Pt}+\mathrm{Pd}$ high $176 \mathrm{ppb}, 5>10 \% \mathrm{Fe}$ & Pyroxenite cut by Andesite and Gabbro dikes \\
\hline $\mathrm{H}-11$ & 500 & 159 & 14-54' & 9 samples $>50 \mathrm{ppb} \mathrm{Pt}+\mathrm{Pd}$ high $100 \mathrm{ppb}$ & Magnetite Pyroxenite to 164 then nonmagnetic Pyroxenite to $\mathrm{EOH}$ \\
\hline $\mathrm{H}-12$ & 600 & 254 & $15-72$ & $\begin{array}{c}9 \text { samples }>50 \mathrm{ppb} \mathrm{Pt}+\mathrm{Pd} \text { high } 159 \mathrm{ppb} \text {, Hi P \& mod } \\
\mathrm{FE}, 14+5 \% \mathrm{Fe}\end{array}$ & Magnetic Gabbro cut by Andesite dikes with mafic Pyroxenite inclusions \\
\hline $\mathrm{H}-13$ & 668 & 250 & $20-100^{\prime}$ & 3 samples $>50 \mathrm{ppb} \mathrm{Pt}+\mathrm{Pd}$ high $150 \mathrm{ppb}$ & Pyroxenite cut by Monzonite dikes \\
\hline $\mathrm{H}-14$ & 500 & 91 & $19-91^{\prime}$ & 9 samples $>50 \mathrm{ppb} P t+P d$ high $110 \mathrm{ppb}$ & Black Amphibolite and clinopyroxenite \\
\hline $\mathrm{H}-15$ & 637 & 458 & $21-131^{\prime}$ & 9 samples $>50 \mathrm{ppb} \mathrm{Pt}+\mathrm{Pd}$ high $595 \mathrm{ppb}, 10>5 \% \mathrm{Mg}$ & Serpentenized Dunite/Wehrlite and Olivine Pyroxenite \\
\hline $\mathrm{H}-16$ & 601 & 256 & $6-31.5^{1}$ & Trace sulfides noted & Moderate to pervasively silicified and argillized Sediments \\
\hline $\mathrm{H}-17$ & 520 & 298 & $8-35^{\prime}$ & 2 samples $>50 \mathrm{Pt}+\mathrm{Pd}$ high $82 \mathrm{ppb}, 6+10 \% \mathrm{Fe}$ & Lake Sediments to 385 then oxidized Pyroxenite \\
\hline Total Hole & 12155 & 3827 & Overburden & & \\
\hline Total Core & 8328 & & & & \\
\hline \multicolumn{4}{|c|}{$\begin{array}{l}\text { Total Composite Sample Intervals } \\
\text { Total Core Intervals Sampled }\end{array}$} & $\begin{array}{l}20 \text { representing } 1032 \text { feet of core }(12 \%) \\
191 \text { samples representing } 995 \text { feet of core (12\%) }\end{array}$ & $\begin{array}{l}8 \text { anomalous intervals with }>50 \mathrm{ppb} P t+\mathrm{Pd} \\
29 \text { anomalous intervals }(15 \%) \text { with }+100 \mathrm{ppb} \mathrm{Pt}+\mathrm{Pd} \text { (high @ } 1330 \mathrm{ppb} \mathrm{Pt})\end{array}$ \\
\hline
\end{tabular}

Only $12 \%$ of the core has been re-sampled to date - of those samples $38 \%$ had anomalous PGE (>50ppb)

\section{Geochemical Notes:}

1) Two distinct populations of PGE's (Pt>PPd and $\mathrm{Pt} \sim=\mathrm{Pd}$ )

2) Magnetite pyroxenites tend to have $\mathrm{Pt} \sim=\mathrm{Pd}$

3) Olivine bearing units ( $\mathrm{hi} \mathrm{Mg}$ ) tend to have the highest $\mathrm{Pt}$ which is $>>\mathrm{Pd}$ and very low (depleted) $\mathrm{Ni}$

4) Anomalous PGE generally has elevated $\mathrm{Mg} \%$ ( +5 to $33 \% \mathrm{MgO}$ )

5) No correlation of anomalous $\mathrm{Cu}$ and $\mathrm{PGE}$

6) Anomalous $\mathrm{Cu}(>100 \mathrm{ppm}$ ) averages over $0.25 \%$ Phosphorus

7) High Cu and P + elevated Au generally has low $\mathrm{Mg}(<2 \%)$ 
Vancouver Petrographics, Attn: J. Vinnell, 8080 Glover Road, Langley B. C. Canada, V1M 3 S3

Enclosed are 30 core samples for preparation of standard thin sections

please stain for K-spar the plugs for samples H9-300.5 and H15-578.5

Thin Section shipping list

\begin{tabular}{|c|c|c|c|}
\hline Hole & Depth & $\mathrm{T} / \mathrm{S}$ & Note \\
\hline $\mathrm{H}-2$ & 200 & $\mathrm{X}$ & Serpetinite after OCT? \\
\hline $\mathrm{H}-2$ & 269 & $\mathrm{X}$ & Coarse grained hbld? Gabbro \\
\hline $\mathrm{H}-2$ & 320 & $\mathrm{X}$ & Fine-grained biotite-rich unit, dike? \\
\hline $\mathrm{H}-2$ & 355 & $\mathrm{X}$ & Representative coarse-grained clinopyroxenite, med. mag \\
\hline $\mathrm{H}-3$ & 656 & $\mathrm{X}$ & Mgt cpxt, banded, cumulate? Mgt. \\
\hline $\mathrm{H}-3$ & 663 & $\mathrm{X}$ & Calc-epidote alt in mgt pxt. Tr. Py? \\
\hline $\mathrm{H}-3$ & 782 & $\mathrm{X}$ & Bt-rich mgt cpxt \\
\hline $\mathrm{H}-3$ & 983 & $\mathrm{X}$ & Layered $\mathrm{mgt}$ and $\mathrm{Bt}$. \\
\hline $\mathrm{H}-4$ & 322 & $\mathrm{X}$ & Fine grained rock, minor $f s$, gabbro? \\
\hline $\mathrm{H}-4$ & 361 & $\mathrm{X}$ & $\mathrm{Gb} A \mathrm{~A}$, lighter weathering clots with tiny red min \\
\hline $\mathrm{H}-6$ & 291 & $\mathrm{X}$ & weherlite $0.5 \mathrm{~cm} \mathrm{cpx}$ xtalls in a srpd oliv matrix \\
\hline $\mathrm{H}-6$ & 570 & $\mathrm{X}$ & Mgt-rich rock, black min with cleavage, hbld? blebby mgt; It green stuff with no cleavage, after cpx?, biotite \\
\hline $\mathrm{H}-8$ & 228.5 & $\mathrm{X}$ & Rep fine grained host \\
\hline $\mathrm{H}-8$ & 387 & $\mathrm{X}$ & F gr mag-bearing unit, Rep Sample \\
\hline $\mathrm{H}-8$ & 572 & $\mathrm{X}$ & Rep fine grained high mag gabbro from near $\mathrm{EOH}$ \\
\hline $\mathrm{H}-9$ & 273.5 & $\mathrm{X}$ & wk por Trach?-andesite wt hrnb lath \\
\hline $\mathrm{H}-9$ & 300.5 & X Stain & K-spar vein $+\tan \min \&$ dis mag \\
\hline $\mathrm{H}-\mathrm{9}$ & 860 & $\mathrm{X}$ & mag pxnt abundant mag \& bio \\
\hline $\mathrm{H}-9$ & 1267 & $\mathrm{X}$ & amphbole + py Sph?? Replacments \\
\hline $\mathrm{H}-9$ & 1378 & $\mathrm{X}$ & Mag pyxnt $+20 \%$ euhedral mag \\
\hline $\mathrm{H}-9$ & 1977 & $\mathrm{X}$ & f/g pyxnt wt varible bio $+5 \%$ dis \& fract py/cpy \\
\hline $\mathrm{H}-10$ & 445.6 & $X$ & Gabbro \\
\hline $\mathrm{H}-12$ & 375 & $x$ & Gabbro \\
\hline $\mathrm{H}-12$ & 585 & $\mathrm{X}$ & Gabbro \\
\hline $\mathrm{H}-14$ & 99 & $x$ & vfg black amphibolite \\
\hline $\mathrm{H}-14$ & 338 & $\mathrm{X}$ & dis sulfide + muscovite? \\
\hline $\mathrm{H}-15$ & 578.5 & X Stain & Ksp Qtz Chl dike \\
\hline $\mathrm{H}-15$ & 630 & $\mathrm{X}$ & Olivine Cpxt \\
\hline $\mathrm{H}-16$ & 303 & $\mathrm{X}$ & Perv Sil around K-spar quartz vein \\
\hline $\mathrm{H}-16$ & 559 & $\mathrm{X}$ & Sericite + Quartz veins $=$ cpy \\
\hline
\end{tabular}

Please send the invoice to Alaska Earth Science, Attn: Bill Ellis, 11401 Olive Lane, Anchorage, Ak. 99515

GMC DATA REPORT 355 


\begin{tabular}{|c|c|c|c|c|c|c|c|c|c|c|c|}
\hline Sample & Hole & Depth & Note & $\mathrm{Pt}(\mathrm{ppb})$ & $\mathbf{P d}(\mathbf{p p b})$ & $A u(p p b)$ & $\mathrm{Cu}(\mathrm{ppm})$ & $\mathrm{Ni}(\mathrm{ppm})$ & Co(ppm) & $\mathrm{Cr}(\mathrm{ppm})$ & $\mathrm{Mg}(\%)$ \\
\hline 3001 & $\mathrm{~A}-2$ & $250.5-251.5$ & Serpentenized dunite pyroxenite breccla & 1330 & 38. & 2 & 16 & 165 & 80 & 95. & 6.07 \\
\hline 3002 & $\mathrm{H}-2$ & $354-55$ & C/g clinopyroxenite, mod. magnetite & 15 & $<2$ & $<2$ & 7 & 42 & 22 & 116 & 1.66 \\
\hline 3003 & $\mathrm{H}-2$ & $451.5-452.5$ & F/g biotite granodiorite & $<5$ & 4 & $<2$ & 70 & 16 & 25 & 38 & 1.32 \\
\hline 3004 & $\mathrm{H}-3$ & $661-663$ & C/g magnetite pyroxenite & 5 & 6 & $<2$ & 11 & 57 & 40 & 39 & 1.24 \\
\hline 3005 & $\mathrm{H}-3$ & 738-39 & Py bearing intermediate andesite dike & 5 & 10 & 102 & 13 & 10 & 11 & 19 & 1.04 \\
\hline 3006 & $\mathrm{H}-3$ & $782-83$ & Biotite-rich magnetite clinopyroxenite & 10 & 24 & $<2$ & 18 & 37 & 35 & 41 & 1.33 \\
\hline 3007 & $\mathrm{H}-3$ & $981-983$ & Layered magnetite pyroxenite with Biotite. & 50 & 58 & $<2$ & 8 & 45 & 43 & 42 & 0.83 \\
\hline 3008 & $\mathrm{H}-4$ & $292-305$ & F/g Pyroxenite & 25 & 18 & 8 & 196 & 21 & 32 & 45 & 0.99 \\
\hline 3009 & $\mathrm{H}-4$ & $442-447$ & F/g Pyroxenite + trace native $\mathrm{Cu}$ & 15 & 28 & 22 & 925 & 25 & 28 & 46 & 0.69 \\
\hline 3010 & $\mathrm{H}-6$ & $284-85$ & Weathered olivine clinopyroxenite & 30 & 2 & $<2$ & 9 & 73 & 21 & 107 & 2.53 \\
\hline 3011 & H-6 & $291-92$ & Peridotite (wehrlite) & 180 & 2 & $<2$ & 9 & 348 & 95 & 93 & 14.3 \\
\hline 3012 & $\mathrm{H}-6$ & $329-31$ & Talc altered weherlite clinopyroxenite breccia & $<5$ & 4 & $<2$ & 25 & 79 & 42 & 286 & 3.03 \\
\hline 3013 & $\mathrm{H}-6$ & $395-96$ & Monzonite dike & $<5$ & $<2$ & $<2$ & 23 & 4 & 4 & 25 & 0.23 \\
\hline 3014 & $\mathrm{H}-6$ & $625-30$ & V. c/g magnetite olivine clinopyroxenite & $<5$ & 8 & $<2$ & 11 & 103 & 56 & 350 & 3.37 \\
\hline 3015 & H-6 & $797-98$ & Interlayered olivine clinopyroxenite and dunite & 270 & 4 & $<2$ & 10 & 171 & 50 & 196 & 6.26 \\
\hline 3016 & $\mathrm{H}-16$ & $266-76$ & Pervasive argillic altered leached intruxive & $<5$ & 4 & $<2$ & 32 & 24 & 14 & 95 & 0.56 \\
\hline 3017 & $\mathrm{H}-16$ & $276-86$ & Pervasive argillic altered leached intruxive & $<5$ & 8 & $<2$ & 52 & 33 & 20 & 78 & 0.74 \\
\hline 3018 & $\mathrm{H}-16$ & $305-307$ & Silicified and quartz vein altered sediments & $<5$ & 18 & $<2$ & 11 & 28 & 14 & 27 & 2.31 \\
\hline 3019 & $\mathrm{H}-16$ & $309-311.5$ & Ouartz/K-spar/Biotite vein cutting altered sediments & $<5$ & $<2$ & $<2$ & 23 & 6 & 1 & 15 & 1.46 \\
\hline 3020 & $\mathrm{H}-16$ & $512-515$ & Silicified and hornfelsed sediments +-sericite + trace $\mathrm{Cu}$ & $<5$ & 6 & $<2$ & 30 & 16 & 9 & 33 & 1.32 \\
\hline 3021 & $\mathrm{H}-16$ & $555-59$ & Hornfelsed and veined sediments +- sericite + trace $\mathrm{Cu}$ & $<5$ & 10 & $<2$ & 62 & 13 & 7 & 39 & 1.71 \\
\hline 3022 & $11=17$ & $385-390$ & Oxidized pyoxenite cutings & 45 & 18 & 16 & 158 & 68 & 47 & 90] & 0.62 \\
\hline 3023 & $\mathrm{H}-17$ & $395-400$ & Oxidized pyoxenite cuttings & 15 & 18 & 2 & 73 & 83 & 76 & 126 & 0.55 \\
\hline 3024 & 11917 & $405-10$ & Oxdized pyoxente cuttings & 40 & 42 & 2 & 130 & 107 & 87 & 131 & 0.73 \\
\hline 3025 & $\mathrm{H}-17$ & $460-65$ & Weathered pyroxenite sand cuttings & $<5$ & 8 & 8 & 184 & 112 & 27 & 522 & 1.09 \\
\hline 3026 & H-8 & $228-235$ & \#226 coarse rejects & 85 & 94 & 10 & 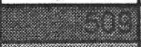 & 33 & 41 & 68 & 0.99 \\
\hline 3027 & 19-8 & $338.5 \cdot 340$ & H253 fire reject or bull & 25 & 44 & $<2$ & 46 & 33 & 42 & 77 & 1 \\
\hline 3028 & $\mathrm{H}-8$ & $305-310$ & \#244 pulp & 10 & 38 & $<2$ & 40 & 41 & 43 & 99 & 0.73 \\
\hline 3029 & $\mathrm{H}-8$ & $535-538$ & $\# 300$ & $<5$ & 28 & $<2$ & 20 & 41 & 43 & 56 & 0.75 \\
\hline 3030 & $\mathrm{H}-9$ & $748-802$ & C-75 composite rejects - Cu noted & 15 & 20 & 6 & 80 & 22 & 36 & 27 & 1.02 \\
\hline 3031 & $1-9$ & $1250-1301$ & C-85 composile relects & 25 & 40 & 2 & 12 & 34 & 86 & 32 & 1.05 \\
\hline 3032 & $\mathrm{H}-9$ & $1949-2000$ & C-99 composite rejects -20 mesh - Cu noted & $<5$ & 36 & 8 & 30 & 43 & 53 & 47 & 0.96 \\
\hline 3088 & 11-10 & 201250 & C.47 compesine rojects & 60 & 14 & 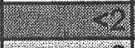 & 27 & 31 & 35 & 32 & 125 \\
\hline 3034 & H-10 & $350-396$ & C-50 composite rejects & 110 & 22 & $<2$ & 29 & 35 & 34 & 27 & 1.29 \\
\hline 3036 & 11.10 & 495.532 & C.53 composite rejects: & 30 & 22 & 22 & 110 & 17 & 30 & 12. & 1.37 \\
\hline 3036 & $\mathrm{H}-9$ & $299-350.5$ & C-63 composite rejects & 15 & 16 & 4 & 245 & 22 & 27 & 36 & 0.75 \\
\hline 3037 & $\mathrm{H}-11$ & $159-199.5$ & C-54 composite rejects & 25 & 6 & $<2$ & 7 & 44 & 19 & 77 & 2.13 \\
\hline 3038 & 11.11: & $303-347$ & C 57 composile rojects & 80 & 4. & 52 & 7 & 62 & 21 & 100 & 2.86 \\
\hline 3039 & $\mathrm{H}-11$ & $447-500$ & C-60 composite rejects & 35 & 2 & $<2$ & 10 & 48 & 17 & 180 & 2.07 \\
\hline 3040 & $\mathrm{H}-12$ & $254-301$ & C-71 composite rejects & 15 & 18 & 6 & 102 & 20 & 25 & 26 & 0.61 \\
\hline
\end{tabular}




\begin{tabular}{|c|c|c|c|c|c|c|c|c|c|c|c|}
\hline Sample & Hole & Depth & Note & Pt(ppb) & $\mathbf{P d}(\mathbf{p p b})$ & $\mathrm{Au}(\mathrm{ppb})$ & Cu(ppm) & Ni(ppm) & Co(ppm) & $\mathrm{Cr}(\mathrm{ppm})$ & $\mathbf{M g}(\%)$ \\
\hline 3041 & $11-12$ & 340.401 & C.73 composile relects & 35 & 52 & 6 & 152 & 13 & 27 & 24 & 0.89 \\
\hline 3042 & H-13 & $449-497.5$ & C-107 composite rejects & 150 & $<2$ & 2 & 5 & 54 & 27 & 258 & 1.86 \\
\hline 3043 & $\mathrm{H}-13$ & $604-668$ & C-110 composite rejects & 25 & $<2$ & $<2$ & 6 & 53 & 25 & 205 & 2.38 \\
\hline 3044 & $\mathrm{H}-14$ & $91-151$ & C-112 composite rejects & 10 & 6 & $<2$ & 52 & 30 & 16 & 115 & 1.39 \\
\hline 3045 & $\mathrm{H}-14$ & $205-251$ & C-114 composite rejects & 30 & 4 & $<2$ & 30 & 45 & 19 & 158 & 1.86 \\
\hline 3046 & 1.-14 & $350-400.5$ & C. 117 composite rejects & 80 & 6 & -2 & 23 & 53 & 22 & 115 & 203 \\
\hline 3047 & $\mathrm{H}-15$ & $470-500$ & C-120 composite rejects & 40 & $<2$ & $<2$ & 30 & 84 & 30 & 154 & 4.6 \\
\hline 3048 & 11.15 & 549637 & C-122 composite rejects & 65 & 22 & 2 & 20 & 146 & 42 & 163 & 7911 \\
\hline 3049 & $\mathrm{H}-17$ & $460-530$ & C-111 composite rejects or cuttings & 5 & 8 & 4 & 72 & 50 & 28 & 111 & 1.23 \\
\hline 3050 & $\mathrm{H}-9$ & $272.5-273.5$ & Porphyritic trachytic andesite with hrnblend lath & $<5$ & 4 & $<2$ & 43 & 4 & 14 & 17 & 0.98 \\
\hline 3051 & $\mathrm{H}-9$ & $300-301$ & K-spar vein with diseminated magnetite & $<5$ & 2 & $<2$ & 49 & 9 & 8 & 51 & 0.52 \\
\hline 3052 & $\mathrm{H}-9$ & $332-335$ & Propylitic altered gabbro + sulfides & $<5$ & 10 & $<2$ & 102 & 17 & 25 & 30 & 1.78 \\
\hline 3053 & $\mathrm{H}-9$ & $735-736.5$ & F/g pyroxenite $+5 \%$ sulfides & 10 & 20 & 26 & 210 & 33 & 115 & 17 & 1.1 \\
\hline 3054 & $\mathrm{H}-9$ & $848.5-850$ & Propylitic altered pyroxenite + sulfides & 20 & 18 & $<2$ & 38 & 54 & 34 & 27 & 3.2 \\
\hline 3055 & $\mathrm{H}-9$ & $858-860$ & Magnetite pyroxenite abundant magnetite \& biotite & $<5$ & 2 & $<2$ & 22 & 91 & 43 & 23 & 1.3 \\
\hline 3056 & $\mathrm{H}-9$ & $1376-1379$ & Magnetite pyroxenite $+20 \%$ euhedral magnetite & 10 & 8 & $<2$ & 44 & 120 & 79 & 47 & 0.75 \\
\hline 3057 & $\mathrm{H}-9$ & $1971-1975$ & F/g pyoxenite with strong biotite and $+5 \%$ sulfides & 10 & 36 & 18 & 80 & 73 & 51 & 81 & 1.41 \\
\hline 3058 & $\mathrm{H}-9$ & $1975-1979$ & F/g pyoxenite with variable biotite and $+5 \%$ sulfides & 10 & 34 & 12 & 360 & 87 & 74 & 51 & 1.4 \\
\hline 3059 & $\mathrm{H}-13$ & 335 & $\mathrm{M} / \mathrm{g}$ monzonite or quartz diorite dike & $<5$ & $<2$ & $<2$ & 18 & 5 & 4 & 32 & 0.27 \\
\hline 3060 & $\mathrm{H}-13$ & $270-280$ & Weathered pyroxenite cuttings & 5 & 4 & $<2$ & 46 & 35 & 19 & 140 & 0.8 \\
\hline 3061 & $\mathrm{H}-13$ & $300-310$ & \begin{tabular}{|l} 
Weathered pyroxenite cuttings \\
\end{tabular} & 5 & 2 & $<2$ & 39 & 27 & 13 & 144 & 0.69 \\
\hline 3062 & $\mathrm{H}-13$ & $320-330$ & \begin{tabular}{|l} 
Weathered pyroxenite cuttings \\
\end{tabular} & $<5$ & $<2$ & 8 & 8 & 29 & 13 & 211 & 0.8 \\
\hline
\end{tabular}

GMC DATA REPORT 355 


\begin{tabular}{|c|c|c|c|c|c|c|c|c|c|}
\hline Sample \# & Hole & Depth & T/S & W/R & RECOMMENDATIONS & Note & $\mathrm{Au}(\mathrm{ppb})$ & $P t(p p b)$ & $\overline{P d}(\mathrm{ppb})$ \\
\hline \begin{tabular}{l|l}
3063 & $H$ \\
\end{tabular} & +-2 & $192-196$ & & & & VCG CPX Srpd Dunite intrusive?? $(-30 \%$ rec $)$ & of & 45 & 24 \\
\hline $3064 \mathrm{H}$ & +2 & $196-204$ & H-2-200 & & & VCG Srpd OLV CPXT $(-15 \%$ r $\theta C)$ & 0 & 110 & 32. \\
\hline $3065 \mathrm{H}$ & +-2 & $246-250.5$ & & & MAGIC-PULP & VCG Srpd Dun Cpx Brx (very poor recovery or lost cort & of & 135 & 10 \\
\hline $3001 \mathrm{H}$ & $\mathrm{H}-2$ & $250.5-25+.5$ & & WR & & VCG Srpd Dun Cpx Bix & 2 & 1330 & 38 \\
\hline & $4-2$ & 269 & $\$-2-269$ (missing) & & & Coarse grained hbld? Gabbro dike & & & \\
\hline & $\mathrm{H}-2$ & 320 & $\mathrm{H}-2-320$ & & & Fine-grained biotite-rich unit, dike? & & & \\
\hline $3182 \mathrm{H}$ & $-1-2$ & $350-354$ & & & NEW SAMPLE & VCG CPXT srpd ollw + bio \& mag & & & \\
\hline $3002 \mathrm{H}$ & +2 & $354-355$ & $\mathrm{H}-2-355$ & WR & MAGIC-PULP & Representative coarse-grained clinopyroxenite, med. n & of & 15 & 요 \\
\hline $3183 \quad 4$ & +2 & $355-360$ & & & NEW SAMPLE & VCG CPXT black olv + bio \& mag & & & \\
\hline $3066 \mathrm{H}$ & $+4-2$ & $375-380$ & & & & VCG it green cpx + amph \& patches Bio & of & 20 & 0 \\
\hline $3067 \mathrm{H}$ & $4-2$ & $380-385$ & & & & VCG it green cox + amph \& patches Bio & of & 0. & 0 \\
\hline 3068 & $4-2$ & $416-421$ & & & & CG CPX/Amph pyroxenite & 0 & of & 0 \\
\hline $3003 \mathrm{H}$ & $\mathrm{H}-2$ & $451.5-452.5$ & & WR & & ffg Bio granodiorite & of & of & (4) \\
\hline $3+84 \mathrm{H}$ & H.2 & $476-482$ & & & NEW SAMPLE & VCG ollv $\mathrm{cpx}$ wehr clots of bio $\& \mathrm{mag}$ & & & \\
\hline $3185 \quad H$ & $\mathrm{H}=2$ & $482-488$ & & & NEW SAMPLE & VCG oliv cpx wehr clots of bio \& mag & & & \\
\hline $3069 \mathrm{H}$ & $\mathrm{H}-2$ & $488-495$ & & & & CG CPX/Amph pyroxenite BrX? & of & 120 & 0 \\
\hline $3186 \quad \mathrm{H}$ & $\mathrm{H}-2$ & $495-500$ & & & NEW SAMPLE & VCG oliv cox wehr clots of bio $\&$ mag & & & \\
\hline $3070 \mathrm{H}$ & $4-3$ & $525-530$ & & & & $\mathrm{~m}-\mathrm{c} / \mathrm{g}$ mag pyroxenite cut by and $\&$ gab dikes & of & of & 20 \\
\hline $3071 \mathrm{H}$ & $\mathrm{H}-3$ & $530-535$ & & & & $\mathrm{~m}$-c/g mag pyroxenite cut by and $\&$ gab dikes & of & 5) & 24 \\
\hline 3072 & $4+3$ & $577-583$ & & & & Im/g mottled mag pyroxenite with minor gab diking & of & of & 6 \\
\hline & $\mathrm{H}-3$ & 656 & $\mathrm{H}-3-656$ & & & Mgt cpxt, banded, cumulate? & & & \\
\hline $3004 \mathrm{H}$ & $\mathrm{H}-3$ & $661-663$ & $\mathrm{H}-3-663$ & & & c/g mag pyxt epd-carb alt + py & 0 & 5. & 6 \\
\hline 3005 & $+3-3$ & $738-39$ & & & & Py bearing int And? dike & 102 & 5 & 10 \\
\hline 3006 & $\mathrm{H}+3$ & $782-783$ & $\mathrm{H}-3-782$ & WR & & Bt-rich mgt cpxt & of & 10 & 24 \\
\hline $3073 \mathrm{H}$ & $\mathrm{H}-3$ & $955-960$ & & & & $f-m / g$ mag pyroxenite with it grn cox with large mag clo & of & 5 & 56 \\
\hline $3074 \quad H$ & $\mathrm{H}-3$ & $960-965$ & & & & f $-m / g$ mag pyroxenite with il grn cpx with large black ar & 0 & 0 & 22 \\
\hline $3075 \mathrm{H}$ & $\mathrm{H} 3$ & $965-970$ & & & & same mag pyroxenite with cpx mag rich zones & of & of & 20 \\
\hline 3076 & $\mathrm{H}-3$ & $970-975$ & & & & same mag pyroxenite with cpx mag rich zones & of & of & 6 \\
\hline 3077 & $\mathrm{H}-3$ & $975-982$ & & & & mostly $\mathrm{f} / \mathrm{g}$ mag proxenito similar to anomalous sample & 0 & of & 28 \\
\hline 3007 & $\mathrm{H}-3$ & $982-983$ & $\mathrm{H}-3-983$ & WA & MAGIC-PULP & Layered mgt and $\mathrm{Bt}+\mathrm{apt}$ & of & 50 & 58 \\
\hline 3078 & $\mathrm{H}-3$ & $983-992$ & & & & mostly f/g mag pyroxenite similar to anomalous sample & of & 10 & 32 \\
\hline 3079 & H-3 & $992-997$ & & & & f-m/g mag pyroxenite with it grn $c p x$ with $I^{\prime}$ and dike at & of & 0 & 8 \\
\hline 3008 & $H-4$ & $292-305$ & & WR & MAGIC-PULP & F/g Pyxt high apatite & 8 & 25 & 18 \\
\hline 3187 & H. 4 & $315-320$ & & & NEW SAMPLE & Fine to med grained mag cpxt $+5 \%$ feld, mag \& apt & & & \\
\hline & $\mathrm{H}=4$ & 322 & $H-4-322$ & & & Fine grained cpxt + mag $\&$ apt & & & \\
\hline 3188 & H-4 & $320-325$ & & & NEW SAMPLE & Fine to med grained mag cpxt $+5 \%$ feld, mag $\&$ apt & & & \\
\hline & $\mathrm{H}-4$ & 361 & H-4-361 & & & mag-apt cpxt & & & \\
\hline 3009 & $\mathrm{H}-4$ & $442-447$ & & $\overline{\text { WR }}$ & & F/g Pyxt + tr native $C u$ & 22 & 15 & 28 \\
\hline 3010 & $H-6$ & $284-85$ & & WR & & Woathered oct? & 0 & 30 & 2 \\
\hline \begin{tabular}{l|l}
3080 & $\mathrm{H}$ \\
30
\end{tabular} & $H-6$ & $285-91$ & & & & c/g it green clinopyroxenite with srpd spots & 0 & 15 & 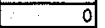 \\
\hline $3011 \mathrm{H}$ & $H-6$ & $291-92$ & H-6-291 & WR & MAGIC-PULP & srpo olv $+\operatorname{cg} x$ wehrlite & of & 180 & 2 \\
\hline 3081 & $\mathrm{H}-6$ & $292-300$ & & & & Wehrite with $15-20 \%$ euhedreal $x$ talls in a Sip matrix & 句 & 30 & 의 \\
\hline 3082 & $H-6$ & $300-305$ & & & & Wehrlite Clinopyroxenite $\mathrm{Brx}$ ? $\mathrm{VC} / \mathrm{g} \mathrm{Cp} x$ around srpd & 0 & 30 & 0 \\
\hline $3083 \mathrm{t}$ & $\mathrm{H} \cdot 6$ & $305-310$ & & & & Wehrifite Clinopyroxenite $\mathrm{Br} x$ ? VC/g Cpxt around srpd & of & 0 & 0 \\
\hline 3084 & $\mathrm{H}-6$ & $310-318$ & & & & Wehrilite Clinopyroxenite $\mathrm{Br}$ ? VC/g Cpxt around srpd & of & of & 요 \\
\hline 3012 it & $\mathrm{H}-6$ & $329-31$ & & & & Talc alteration & a & o & 4 \\
\hline 3013 & $\mathrm{H}-6$ & $395-96$ & & WR & & Monzonite-Dike? & of & of & 0 \\
\hline $3189 \mathrm{di}$ & $H-6$ & $425-4,30$ & & & NEW SAMPLE & VCG srpd dun/cox brx intercum oliv cum $c p \times$ to $2^{\prime \prime}$ & & & \\
\hline 3190 & $H \cdot 6$ & $430-435$ & & & NEW SAMPLE & VCG sppd dun cpx brx intercum oliv cum cpx $102^{*}$ & & & \\
\hline 3199 th & $\mathrm{H}-6$ & $435-440$ & & & NEW SAMPLE & VCG cpx cumulate wh fresh intercum olv cpx to $2^{n}$ & & & \\
\hline 3085 & H.6 & $440-446$ & & & & Oliv Cpx cumulate with patches of massive black olivin & of & 75 & : \\
\hline 3086 & $\mathrm{H}-6$ & $446-452$ & & & & Oliv Cpx cumulate with patches of massive black olivin & of & 50 & 0 \\
\hline 3192 & $\mathrm{H}-6$ & $560-570$ & $\mathrm{H}-6-570$ & & NEW SAMAPLE & $V C / G$ cpxt to $2^{\prime \prime}+$ black ofiv bio mag + hmb & & & \\
\hline 3193 th & $\mathrm{H}-6$ & $570-580$ & & & NEW SAMPLE & $\mathrm{VC} / \mathrm{G}$ cpxt to $2^{\mathrm{a}}+$ black oliv bio mag + hmb & & & \\
\hline $3014 \mathrm{ft}$ & $\mathrm{H}-6$ & $625-30$ & & WR & & $\mathrm{vc/g}$ mag otv coxt? & of & of & 8 \\
\hline $\begin{array}{ll}3087 \\
301\end{array}$ & H-6 & $790-797$ & & & MAGIC-PULP & mostly $\mathrm{c} / \mathrm{g}$ ckinapyroxenite with $4^{4}$ patches of wherlite $\mathrm{W}$ & of & 10 & 0 \\
\hline 3015 & H.6 & $797-98$ & & WR & & lay on cpxt wi dun layers & of & 270 & 4 \\
\hline 3088 & $H-6$ & $798-804$ & & & & mostly a/g tf groen olinopyroxenite with srpd olivine pat & of & of & 여 \\
\hline 3089 & $H-6$ & $804-810$ & & & & mostly $\mathrm{c} / \mathrm{g}$ it green clinopyroxenite with srpd olivine pat & 0 & of & 의 \\
\hline 3090 & $\mathrm{H}-6$ & $810-815$ & & & & mostly c/g it green clinopyroxenite with more srpd olivir & of & 5 & 4 \\
\hline 3091 & $\mathrm{H}-6$ & $815-821$ & & & & cig clinopyroxenite with some black srpd olivine patche & 0 & of & 0 \\
\hline $\mathrm{H}-7 \mathrm{C}-1$ & H-7 & 151.200 & & & & C-1 composite rejects Humble & & & \\
\hline $\mathrm{H}-7 \mathrm{C}-2$ & $H .7$ & $200-250$ & & & & C-2 composite rejects Humble & & & \\
\hline $\mathrm{H}-7 \mathrm{C}-3$ & $\mathrm{H}-7$ & $250-296.5$ & & & & C-3 composite rejects Humble & & & \\
\hline $\mathrm{H}-7 \mathrm{C}-4$ & H-7 & $296.5-336$ & & & & C-4 composite rejects Humble & & & \\
\hline $\mathrm{H}-7 \mathrm{C}-5$ & H-7. & $336-370$ & & & & c-5 composite rejecis Humble & & & \\
\hline $\mathrm{H}-7 \mathrm{C}-6$ & $\mathrm{H}-7$ & $370-406.25$ & & & & C-6 composite rejects Humble & & & \\
\hline $\mathrm{H}-7 \mathrm{C}-7$ & $H+7$ & $406.25-449$ & & & & C-7 composite rejects Humble & & & \\
\hline H.7C-8 & $\mathrm{H}-7$ & $449-500$ & & & & C- 8 composite rejects Humble & & & \\
\hline $\mathrm{H}-7 \mathrm{C}-9$ & $\mathrm{H}-7$ & $500-548.7$ & & & & C-9 composite rejects Humble & & & \\
\hline $\mathrm{H}-7 \mathrm{C}-10$ & H.7.7 & $548.7-600$ & & & & C-10 composite rojects Humble & & & \\
\hline $\mathrm{H}-7 \mathrm{C}-11$ & H-7 & $600-650$ & & & & C- 11 composite rejects Humble & & & \\
\hline $\mathrm{H}-7 \mathrm{C}-12$ & $\mathrm{H}-7$ & $650-699$ & & & & C- 12 composite rejects Humble & & & \\
\hline $\mathrm{H}-7 \mathrm{C}-13$ & $H+7$ & $699-747$ & & & & C-13 composite rejects Humble & & & \\
\hline $\mathrm{H}-7 \mathrm{C}-14$ & H-7 & 747.799 & & & & C-14 composite rejects Humble & & & \\
\hline $\mathrm{H}-7 \mathrm{C}-15$ & $\mathrm{H}-7$ & $799-849$ & & & & C-15 composile rejects Humble & & & \\
\hline $\mathrm{H}-7 \mathrm{C}-16$ & $H-7$ & $849-899$ & & & & C-16 composite rejects Humble & & & \\
\hline $\mathrm{H}-7 \mathrm{C}-17$ & H-7 & $899-950$ & & & & C- 17 composite rejects Humble & & & \\
\hline H-7C-18 & H-7 & $950-1001$ & & & & C-18 composite rejects Humble & & & \\
\hline $\mathrm{H}-7 \mathrm{C}-27$ & $\mathrm{H}-7$ & $1001-1050.5$ & & & & C-27 composite reiects Humble & & & \\
\hline $\mathrm{H}-7 \mathrm{C}-28$ & $H-7$ & $1050.5 \times 1102$ & & & & C. 28 composite rejects Humblo & & & \\
\hline $\mathrm{H}-7 \mathrm{C}-29$ & H-7 & $1102-1154$ & & & & C. 29 composite rejects Humble & & & \\
\hline $\mathrm{H}-7 \mathrm{C}-30$ & H-7 & $1154-1200.5$ & & & & C-30 composite rejects Humble & & & \\
\hline $\mathrm{H}-7 \mathrm{C}-31$ & H-7 & $1200.5-1251$ & & & & C-31 composite rejects Humble & & & \\
\hline H-7C-32 & $\mathrm{H}-7$ & $1251-1302$ & & & & C-32 composite rejects Humble & & & \\
\hline $\mathrm{H}-7 \mathrm{C}-33$ & H.7 & $1302-1354$ & & & & C-33 composite rejects Humble & & & \\
\hline
\end{tabular}




\begin{tabular}{|c|c|c|c|c|c|c|c|c|c|}
\hline Sample \# & Hole & Depth & $T / S$ & W/R & RECOMMENDATIONS & Note & $\mathrm{Au}(\mathrm{ppb})$ & $P t(p p b)$ & $\mathrm{Pd}(\mathrm{ppb})$ \\
\hline $\mathrm{H}-7 \mathrm{C}-34 \mathrm{I}$ & $\mathrm{H}-7$ & $1354-1401$ & & & & C-34 composite rejects Humble & & & \\
\hline $\mathrm{H}-7 \mathrm{C}-35 \mathrm{H}$ & $\mathrm{H}-7$ & $1404-1451.5$ & & & & C-35 composite rejects Humble & & & \\
\hline $\mathrm{H}-7 \mathrm{C}-36 \mathrm{G}$ & $\mathrm{H}-7$ & $1451.5-1502$ & & & & C-36 composite rejects Humble & & & \\
\hline $\mathrm{H}-7 \mathrm{C}-37 \mathrm{~F}$ & $H-7$ & $1502-1551$ & & & & C-37 composite rejects Humble & & & \\
\hline $\mathrm{H}-7 \mathrm{C}-38 \mathrm{H}$ & $\mathrm{H}-7$ & $1551-1602$ & & & & C-38 composite rejects Humble & & & \\
\hline H-7C-39) & $\mathrm{H}-7$ & $1602-1652.5$ & & & & C-39 composite rejects Humble & & & \\
\hline $\mathrm{H}-7 \mathrm{C}-40 \mathrm{H}$ & $\mathrm{H}-7$ & $1652.5-1701$ & & & & C-40 composite rejacts Humble & & & \\
\hline $\mathrm{H}-7 \mathrm{C}-41$ & $4-7$ & $1701-15750$ & & & $\therefore$ & C-41 composite rejects Humble & & & \\
\hline $\mathrm{H}-7 \mathrm{C}-42 \mathrm{H}$ & $\mathrm{H}-7$ & $1750-1799$ & & & & C-42 composite rejects Humble & & & \\
\hline $\mathrm{H}-7 \mathrm{C}-43$ & $\mathrm{H}-\mathrm{7}$ & $1799-1851.5$ & & & & C-43 composite rejects thumble & & & \\
\hline $\mathrm{H}-7 \mathrm{C}-44$ & $H-7$ & $1851.5-1900.5$ & & & & C-44 composite rejects Humble & & & \\
\hline $\mathrm{H}-7 \mathrm{C}-45$ & $\mathrm{H}-7$ & $1900.5-1950$ & & & & C-45 composite rejects Humblo & & & \\
\hline $\mathrm{H}-7 \mathrm{C}-46$ & $\mathrm{H}-7$ & $1950-2000$ & & & & C-46 composite rejects Humble & & & \\
\hline $3221+1$ & $\mathrm{H}-7$ & $1950-2000$ & & & & -200 mesh pulp fm Humble $\mathrm{Fe}$ anahysis & & & \\
\hline $\mathrm{H}-8 \mathrm{C}-19 \mathrm{~F}$ & $\mathrm{H}-\mathrm{g}$ & $222-251$ & & & & C-19 composite rejects Humble & & & \\
\hline 3092 & $\mathrm{H}-8$ & $222-228$ & & & & t-m/g dark gray magnetite pyroxenite some feox stain e & 14 & 30 & 44. \\
\hline $3026 \quad$ H & $\mathrm{H}-8$ & 228-235 & & & & \#226 coarse reject & $10 \mid$ & 85 & 94 \\
\hline 3093 & $\mathrm{H}-\mathrm{B}$ & $228-235$ & $H-8-228.5$ & & MAGIC-PLLP & $f-m / g$ dark gray magnelite pyroxenite & . & 40 & 56 \\
\hline 3094 & $\mathrm{H}-\mathrm{B}$ & $235-240$ & & & & f-m g dark gray magnetite pyroxenite cut by homblend & of & of & 12 \\
\hline 3095 & $\mathrm{H}-8$ & $240-246$ & & & & fin/g magnetite pyroxenite & of & 15 & 48 \\
\hline $\mathrm{H}-8 \mathrm{C}-20$ & $\mathrm{H}-8$ & $251-300$ & & & & C-20 composite rejects Humble & & & \\
\hline$H-8 \mathrm{C}-21$ & $\mathrm{H}-8$ & $300-350$ & & & & C-21 composite rejects Humble & & & \\
\hline 3028 & $\mid+1+8$ & $305-310$ & & & & \#244 Pulp? & of & 10 & 38 \\
\hline 3194 & $\mathrm{H}-8$ & $310-315$ & & & NEW SAMPLE & m-c/g mag pyroxenile + bio cut by of veins & & & \\
\hline 3195 & $\mathrm{H}-8$ & $315-320$ & & & NEW SAMPLE & m-c/g mag pyroxenite cut by $2^{\prime}$ QF dike & & & \\
\hline 3096 & $\mathrm{H}-8$ & $320-325$ & & & MAGIC-PULP & f-m/g dark gray magnetite pyroxenite with irregular mad & 2 & 100 & 48 \\
\hline 3097 & $\mathrm{H}-\mathrm{B}$ & $325-329$ & & & & f-m/g dark gray magnetite pyroxenite with irregutar mas & - & 0 & 22 \\
\hline 3027 & $\mathrm{H}-8$ & $338.5-340$ & & & & \#253fine rejectpulp? & of & 25 & 44 \\
\hline $\mathrm{H}-8 \mathrm{C}-22$ & $\mathrm{H}-8$ & $350-402$ & & & & C-22 composite tejects Humble & & & \\
\hline & $\mathrm{H}-\mathrm{8}$ & 387 & $\mathrm{H}-8-387$ & & & F gr mag-bearing unit, Rep Sample & & & \\
\hline \begin{tabular}{|l|}
$H-8 C-23$ \\
\end{tabular} & $\mathrm{H}-8$ & $402-454$ & & & & C-23 composite rejects Humble & & & \\
\hline \begin{tabular}{|l|}
$\mathrm{H}-8 \mathrm{C}-24$ \\
\end{tabular} & $\mathrm{H}-\mathrm{B}$ & $454-500$ & & & & C-24 composite rejects Humble & & & \\
\hline H-8C-25 & $\mathrm{H}-8$ & $500-550$ & & & & C-25 composite rejects Humble & & & \\
\hline \begin{tabular}{|l|l}
3029 \\
\end{tabular} & $H-8$ & $535-538$ & & & & \#300 coarse reject & of & of & 28 \\
\hline $\mathrm{H}-8 \mathrm{C}-26$ & $\mathrm{H}-8$ & $550-576.5$ & & & & C-26 composite rejects Humble & & & \\
\hline 3196 & $\mathrm{H}-8$ & $559-566$ & & & NEW SAMPLE & m-c/g mag pyroxenite $+3^{*}$ mas mag + brn/cpy & & & \\
\hline & $\mathrm{H}-8$ & 572 & $\mathrm{H}-8-572$ & & & Rep fine grained mag cpxt from near $\mathrm{EOH}$ & & & \\
\hline 3050 & $\mathrm{H}-\mathrm{g}$ & $272.5-273.5$ & $H-9-273.5$ & WA & & wk por Trach?-andesite wt hrnb lath & of & of & 4 \\
\hline 3036 & $\mathrm{H}-9$ & $299-350.5$ & & & & C- 63 composit rejocts & 4 & 15 & 16 \\
\hline 3051 & Hing & $300-301$ & $\mathrm{H}-9-300.5$ & WR & MAGIC-PULP & K-spar vein $+\tan$ min \& dis mag & of & of & 2 \\
\hline 3052 & $\mathrm{H}-\mathrm{g}$ & $332-335$ & & & MAGIC-PULP & Carb/Epd/chl - Prop Alt + py \& tr Cpy & 0) & 요 & 10 \\
\hline 3053 & $\mathrm{H}-9$ & $735-736.5$ & & & MAGIC-PULP & t/g pyxnt $+5 \%$ py + tr Cpy & 26 & 10 & 20 \\
\hline 3030 & H-9 & $748-802$ & & & & C-75 composiz rejects - Cu noted & 6. & 15 & 20 \\
\hline 3054 & $\mathrm{H}-9$ & $848.5-850$ & & & & Prop alt ChV/Carb/Srp + py \& ir Cpy & of & 20 & 18 \\
\hline 3055 & $\mathrm{H}-\mathrm{9}$ & $858-860$ & $\mathrm{H}-9-860$ & WR & & mag pxnt abundant mag \& bio & of & 이 & 2 \\
\hline 3198 & H-9 & $1240-1245$ & & & NEW SAMPLE & $\mathrm{m} / \mathrm{g}$ mag pxnt + some bio \& teld & & & \\
\hline 3197 & $H-9$ & $1245-1250$ & & & NEW SAMPLE & mag pxnt + abundant bio mod mag & & & \\
\hline 3098 & H-8 & $1250-1255$ & & & & Drk gray-green med/gr magnetite pyroxenite & 2 & 145. & 100 \\
\hline 3031 & $\mathrm{H}-\mathrm{S}$ & $1250-1301$ & & & & C-85 composit rejects & t & 25 & 40 \\
\hline 3099 & $\mathrm{H}-\mathrm{9}$ & $1255-1260$ & & & & Drk gray-green med/gr magnelite pyroxenite larger ma & of & 요 & 30 \\
\hline 3101 & $\sqrt{\mathrm{H}-9}$ & $1260-1265$ & & & & Drk gray-green med/gr magnetite pyroxenite & of & 20 & 40 \\
\hline 3102 & $\mathrm{H}-9$ & $1265-1270$ & $\mathrm{H}-\mathrm{9}-1267$ & & MAGIC-PULP & $\mathrm{m} / \mathrm{g}-\mathrm{clg}$ mag hrnb $\mathrm{cpxt}$ with minor sulfides intergrown a & of & of & 4 \\
\hline 3103 & $\mathrm{H}-\mathrm{g}$ & $1270-1275$ & & & & Drk gray-green $\mathrm{m} / \mathrm{g}$ to $\mathrm{d} / \mathrm{gr}$ magnetite pyroxenite more & of & of & 4 . \\
\hline 3104 & $\mathrm{H}-\mathrm{9}$ & $1275-1280$ & & & & Drk gray-green m/g to c/gr magnetite pyroxenite more & of & of & 4. \\
\hline 3105 & H-9 & $1280-1285$ & & & & Drk gray-green m/g to c/gr magnetile pyroxenite more & of & of & 4 \\
\hline 3106 & $\mathrm{H}-9$ & $1285-1290$ & & & & finer grained drk gray-green magnetite pyroxenite trace & of & 20. & 54 \\
\hline 3107 & H-9 & $1290-1295$ & & & MAGIC-PULP & finer grained drk gray-green magnetite pyroxenite biotit & 8) & 85 & 76 \\
\hline 3108 & $\mathrm{H}-9$ & $1295-1301$ & & & & finer grained drk gray-green magnetite pyroxenite prop & 6 & of & 46 \\
\hline 3199 & $\mathrm{H}-\mathrm{g}$ & $1301-1305$ & & & NEW SAMPLE & fine grained green clinopyroxenite & & & \\
\hline 3200 & $\mathrm{H}-\mathrm{g}$ & $1305-1310$ & & & NEW SAMPLE & $\mathrm{m} / \mathrm{g}$ mag pxnt abundant mag \& bio $1 "$ feld vein & & & \\
\hline 3056 & $\mathrm{H}-\mathrm{9}$ & $1376-1379$ & $H-9-1378$ & & & Mag pyxnt $+20 \%$ euhedral mag & of & 10 & 8 \\
\hline 3032 & $\mathrm{H}-\mathrm{9}$ & $1949-2000$ & & & & C-99 composit reject -20 mesh - Cu noted & 8 & 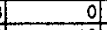 & 36 \\
\hline 3057 & $\mathrm{H}-\mathrm{O}$ & $1971-1975$ & & & & f/g pyxnt str bio $+5 \%$ py/cpy Highest Humble Cu assay & 18 & 10 & 36 \\
\hline 3058 & H-9 & $1975-1979$ & $\mathrm{H}-9-1977$ & WR & MAGIC-PULP & fi/g pyxnt wt varible bio $+5 \%$ dis \& fract py/cpy & 12 & 10 & 34 \\
\hline 3033 & $\mathrm{H}-10$ & $201-250$ & & & & C-47 composit rejects & of & 60 & 14 \\
\hline 3119 & $\mathrm{H}-10$ & $203-208$ & & & & t/g dark gray-green magnettie pyroxenite with rusty spd & of & 30 & 8 \\
\hline 3109 & $\mathrm{H}-10$ & $350-355$ & & & & tig to m/g dark gray-green magnetite pyroxenite 1 ' prof & of & 45 & 18 \\
\hline 3034 & $H-10$ & $350-396$ & & & & C-50 composit rejects & 0 & 110 & 22 \\
\hline 3110 & $\mathrm{H}-10$ & $355-360$ & & & & f/g to $\mathrm{m} / \mathrm{g}$ dark gray-green magnetite pyroxenite increa & of & 0 & 6 \\
\hline 3111 & $H-10$ & $360-365$ & & & & fig to $\mathrm{m} / \mathrm{g}$ dark gray-green magnetite pyroxenite increa & of & 25 & 12 \\
\hline 3112 & $H-10$ & $365-370$ & & & & fig to $\mathrm{m} / \mathrm{g}$ dark gray-green magnetite pyroxenite increa & 0 & 20 & 10 \\
\hline 3113 & $\mathrm{H}-10$ & $375-375$ & & & & c/g with larger cpX and euhedral mag xtalls to $1 \mathrm{~cm}$ & of & 15 & 10 \\
\hline 3114 & $\mathrm{H}-10$ & $375-380$ & & & & $\mathrm{c} / \mathrm{g}$ with larger $\mathrm{cpx}$ and euhedral mag $x$ alls to $1 \mathrm{~cm}$ & of & 15 & 10 \\
\hline 3115 & $H-10$ & $380-385$ & & & & flg to $\mathrm{m} / \mathrm{g}$ dark gray-green magnetite pyroxeniteprop al & 0 & 145 & 22 \\
\hline 3116 & $\mathrm{H}-10$ & $385-390$ & & & MAGIC-PULP & t/g to $\mathrm{m} / \mathrm{g}$ dark grav-green magnetite pyroxeniteprop all & of & 160 & 16 \\
\hline 3117 & $\mathrm{H}-10$ & 390.395 & & & & $\mathrm{f} / \mathrm{g}$ to $\mathrm{m} / \mathrm{g}$ dark gray-green magnetite pyroxenite $/ \mathrm{g}$ gat & of & 45 & 24 \\
\hline 3118 & $\mathrm{H}-10$ & $395-400$ & & & & $\mathrm{~m} / \mathrm{g}$ to $\mathrm{c} / \mathrm{g}$ dark gray-green magnetite pyroxenite f/g ga & 0 & 25 & 18 \\
\hline & $\mathrm{H}-10$ & 445.6 & $H-10-445.6$ & & & clay/ser att Gabbro wt apatite & & & \\
\hline 3201 & H-10 & $444.5 \cdot 450$ & & & NEW SAMPLE & drk gin pyrox amph feld gabbro & & & \\
\hline 3035 & $H-10$ & $495-532$ & & & & C-53 composit rejects & of & 30 & 22 \\
\hline 3037 & $H-11$ & $159-199.5$ & & & & C-54 composit rejects & 0 & 25 & 6 \\
\hline 3120 & $\mathrm{H}-11$ & $303-308$ & & & & c/g med to it green clinopyroxenite $~ 90 \%$ not magnetic & of & 50 & 2 \\
\hline 3038 & $\mathrm{H}-14$ & $303-347$ & & & & C.57 composit rejacts & of & 80 & 4 \\
\hline 3121 & $\mathrm{H}-11$ & $308-313$ & & & & e/g med to $1 \mathrm{~g}$ green clinopyroxenite $-90 \%$ not magnetic & of & 65 & 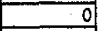 \\
\hline 3122 & $\mathrm{H}=11$ & $313-318$ & & & & dg med to li green clinopyroxenite $-90 \%$ not magnetic & of & 100 & 0 \\
\hline 3123 & H-11 & $318-323$ & & & & c/g med to lt green clinopyroxenite $\sim 90 \%$ not magnetic & of & 501 & 이 \\
\hline
\end{tabular}




\begin{tabular}{|c|c|c|c|c|c|c|c|c|c|}
\hline Sample \# & Hole & Depth & $\mathrm{T} / \mathrm{S}$ & W/A & IRECOMMENDATIONS & Note & \begin{tabular}{|l|l|}
$\mathrm{Au}(\mathrm{ppb})$ \\
\end{tabular} & Pt(ppb) & $\mathrm{Pd}(\mathrm{ppb})$ \\
\hline 3124 & $\mathrm{H}-11$ & $323-328$ & & & & c/g med to tt green clinopyroxenite $-90 \%$ not magnetic & 0 & 20 & 0 \\
\hline 3125 & $\mathrm{H}-11$ & $328-333$ & & & & c/g med to lt green clinopyroxenite $-90 \%$ not magnetic & of & 20 & 0 \\
\hline 3126 & $H-11$ & $333-338$ & & & & c/g med to ll green clinopyroxenite $-90 \%$ not magnetic & 0 & 60 & 0 \\
\hline 3127 & $\mathrm{H}-11$ & $338-343$ & & & & c/g med to fi green clinopyroxenite $-90 \%$ not magnetic & 10. & 100 & 0 \\
\hline 3128 & $\mathrm{H}-11$ & $343-347$ & & & & c/g med to it green clinopyroxenite $-90 \%$ not magnetic & of & 45 & 0 \\
\hline 3202 & Hit-11. & $347-352$ & & & NEW SAMPLE & dik gin m/g pyroxenite + some bio \& feld & & & \\
\hline 3203 & $\mathrm{H}-11$ & $352-357$ & & & NEW SAMPLE & drk gin m/g pyroxenite + some bio \& feld & & & \\
\hline 3039 & $\mathrm{H}=11$ & 447.500 & & & & C-60 composit rejects & 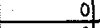 & 35 & 2 \\
\hline 3040 & $\mathrm{H}-12$ & $254-301$ & & & & C-71 composit rejects & 6 & 15 & 18 \\
\hline 3129 & $\mathrm{H}-12$ & $349-355$ & & & & $\mathrm{~m} / \mathrm{g}$ magnetic hornblend gabbro $\mathrm{Cl}-60 \%$ with patches & 4 & 10. & 26 \\
\hline 3041 & $\mathrm{H}-12$ & $349-401$ & & & & C-73 composit rejects & 6 & 35 & 52 \\
\hline 3130 & $H-12$ & $355-360$ & & & & t/g propalyic allered andesite dike & of & 60 & 80 \\
\hline 3131 & H-12 & $360-365$ & & & & mafic homblend gabbro with minor epidote carbonate & of & 15 & 62 \\
\hline 3132 & $\mathrm{H}-12$ & $365-370$ & & & & m/g magnetic hornbiend gabbro with increasing mafic & 12 & 10 & 54 \\
\hline 3133 & $\mathrm{H}-12$ & $370-375$ & & & & $\mathrm{~m} / \mathrm{g}$ magnetic homblend gabbro with mafic inclusions & 4 & of & 58. \\
\hline 3134 & $H+12$ & $375-380$ & $\mathrm{H}-12-375$ & & MAGIC-PULP & Im/g magnetic homblend gabbro with increasing mafic & of & 10 & 32 \\
\hline 3135 & $\mathrm{H}-12$ & $380-385$ & & & & ing magnetic homblend gabbro with mafic inclusions & 0 & 10 & 40 \\
\hline 3136 & $H-12$ & $385-390$ & & & & m/g magnetic homblend gabbio with mafic inclusions & 0 & 5 & 24 \\
\hline 3137 & $\mathrm{H}-12$ & $390-395$ & & & & $\mathrm{~m} / \mathrm{g}$ magnetic hornblend gabbro with mafic inclusions $\mathrm{e}$ & 16 & 0 & 22 \\
\hline 3138 & H.12 & $395-401$ & & & & Imafic hornblend gabbro with minor epidote on fractures & 2 & 115 & 44 \\
\hline 3204 & $\mathrm{H}=12$ & $401-406$ & & & NEW SAMPLE & hom gabbro epd on fract + CPY \& mag clots & & & \\
\hline 3205 & $\mathrm{H}-12$ & $406-411$ & & & NEW SAMPLE & horn gabbro mod mag & & & \\
\hline 3206 & $\mathrm{H}-12$ & $580-585$ & & & NEW SAMPLE & Imafic gabbro mod to str magnetic clots of $c p x$ & & & \\
\hline & $H-12$ & 585 & $\mathrm{H}-12-585$ & & & Att Gabbro & & & \\
\hline 3207 & $\mathrm{H}-12$ & $585-590$ & & & NEW SAMPLE & mafic gabbro moo to str magnetic clots of cpX & & & \\
\hline 3060 & $\mathrm{H}-13$ & $270-280$ & & & & cuttings of weathered pyroxenite & 0 & 5 & 4 \\
\hline 3061 & H-13 & $300-310$ & & & & cuttings of weathered pyroxenite & 0 & 5 & 2 \\
\hline 3062 & $\mathrm{H}-13$ & $320-330$ & & & & cuttings of weathered pyroxenite & 8 & of & 0 \\
\hline 3059 & H.13 & 335 & & WR & MAGIC-PULP & m/g monz or qtz dir dike & of & of & 0 \\
\hline 3139 & $\mathrm{H}-13$ & $448-453$ & & & & c/g med to tt green magnetite clinopyroxenite with $\mathrm{f} / \mathrm{g}$ if & of & 35 & 4 \\
\hline 3042 & $\mathrm{H}-13$ & $449-497.5$ & & & & C-107 composit rejacts & 2 & 150 & 은 \\
\hline 3140 & $\mathrm{H}-13$ & $453-458$ & & & & c/g med to H green magnetite clinopyroxenite with $\mathrm{f} / \mathrm{g}$ if & 苟 & 0 & 4 \\
\hline 3141 & $H-13$ & $458-463$ & & & & c/g med to It green magnetite clinopyroxenite with $\mathrm{t} / \mathrm{g}$ if & 0 & of & 0 \\
\hline 3142 & $\mathrm{H}-13$ & $463-468$ & & & & m/g to c/g clinopyroxenite varible magnetite sparce srp & 아 & 5) & 요 \\
\hline 3143 & $\mathrm{H}-13$ & $468-473$ & & & & $\mathrm{~m} / \mathrm{g}$ to c/g clinopyroxenite increasing magnetite sparce & 0 & of & 0 \\
\hline 3144 & $\mathrm{H}-13$ & $473-478$ & & & & d/g med to lt green magnetite clinopyroxenite minor bid & of & 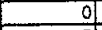 & 요 \\
\hline 3145 & $H-13$ & $478-483$ & & & & c/g to volg magnetite clinopyroxenite xtalls to $2^{\circ}$ less $m$ & 可 & 5 & 0 \\
\hline 3146 & $\mathrm{H}=13$ & $483-488$ & & & & c/g clinoppyroxenite with talc altered fractures at $485 \$$ & of & 40 & 0 \\
\hline 3147 & $\mathrm{H}-13$ & $488-493$ & & & & c/g clinoppyroxenite with biotite + talc altered fractures & 0 & 의 & 0 \\
\hline 3148 & $\mathrm{H}-13$ & $493-498$ & & & & c/g clinoppyroxenite with talc aitered fractures, $I^{\prime} \mathrm{t} / \mathrm{g}$ dif & 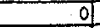 & 20 & 0 \\
\hline 3149 & $H-13$ & $498-503$ & & & & $\mathrm{vc} / \mathrm{g}$ to pegmatoidal magnetite clinopyroxenite xtalls to & of & 65 & 0 \\
\hline 3150 & $4-13$ & $503-508$ & & & MAGIC-PULP & 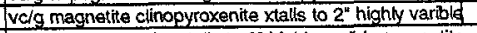 & of & 135 & 0 \\
\hline 3208 & $\mathrm{H}-13$ & $508-513$ & & & NEW SAMPLE & ve/g clinopyroxenite xtalls to $2^{n}$ highly varible magnetite & & & \\
\hline 3209 & $\mathrm{H}-13$ & $513-518$ & & & NEW SAMPLE & $\mathrm{vc} / \mathrm{g}$ clinopyroxenite xtalls to $2^{4}$ highly varble magnetite & & & \\
\hline 3043 & $\mathrm{H}-13$ & $604-668$ & & & & C-110 composit rejects & of & 25 & 0 \\
\hline 3044 & $\mathrm{H}-14$ & $91-151$ & & & & C-112 composit rejects & 요 & 10 & 6 . \\
\hline 3216 & $\mathrm{H}-14$ & $97-103$ & $\mathrm{H}-14-99$ & & NEW SAMPLE & fi-m/g black hmb bio cpxt + srpd oliv & & & \\
\hline 3045 & $\mathrm{H}-14$ & $205-251$ & & & & $\mathrm{C}$-114 composit rejects & of & 30. & 4 \\
\hline 3151 & $\mathrm{H}-14$ & $326-336$ & & & & $\mathrm{vc} / \mathrm{g}$ clinopyroxenite with zones of black $0.5 \mathrm{~cm}$ Aamph & o & 95 & 8 \\
\hline 3152 & $\mathrm{H}-14$ & $336-341$ & $\mathrm{H}-14-338$ & & MAGIC-PULP & $\mathrm{m} / \mathrm{g}$ to $\mathrm{vc} / \mathrm{g} \mathrm{cpxt}$ with patches of sipd olivine ( + tr sulfid & of & 65 & 10 \\
\hline 3153 & $\mathrm{H}-14$ & $341-346$ & & & & $\mathrm{~m} / \mathrm{g}$ to a/g clinopyroxenite biotite common plus smod pa & 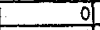 & 60 & 0 \\
\hline 3154 & H-14 & $346-351$ & & & & $\mathrm{~m} / \mathrm{g}$ to $\mathrm{c} / \mathrm{g}$ clinopyroxenite biotite common plus $3 \mathrm{~cm}$ fre & 4 & 100 & 10 \\
\hline 3046 & $\mathrm{H}-14$ & $350-400.5$ & & & & C-117 composit rejects & of & 80. & 6 \\
\hline 3155 & $\mathrm{H}-14$ & $351-357$ & & & MAGIC-PULP & $\mathrm{m} / \mathrm{g}$ to $\mathrm{c} / \mathrm{g}$ clinopyroxenite $(\mathrm{vc} / \mathrm{g}$ at 354$)$ srpd olivine $\mathrm{pa}$ & of $12-12 \cdot 0$ & 105 & 6 \\
\hline 3156 & H-14 & $357-362$ & & & & varible from $t / g$ to $\mathrm{c} / \mathrm{g} \mathrm{cpxt}$ with fe stained srpd olivine $\mathrm{f}$ & of & 65 & 10 \\
\hline 3157 & $\mathrm{H}-14$ & $362=367$ & & & & varible from $\mathrm{yg}$ to $\mathrm{d} / \mathrm{g}$ cpxt with fe stained srpd olivine & of & 901 & 8 \\
\hline 3158 & H $H=14$ & $367-372$ & & & & varible from $1 / \mathrm{g}$ to $\mathrm{c} / \mathrm{g}$ cpxt with fe stained srpd olivine & of & 55 & 6 \\
\hline 3159 & $\mathrm{H}-14$ & $372-377$ & & & & varible from $t / g$ to $c / g$ cpxt with fe stained srpd olivine of & 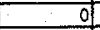 & 50 & 0 \\
\hline 3160 & $\mathrm{H}-14$ & $377-382$ & & & & varible from $t \mathrm{~g}$ to $\mathrm{c} / \mathrm{g}$ cpxt with fe stained srpd olvine of & of & 30 & 0 \\
\hline 3161 & $\mathrm{H}-14$ & $382-387$ & & & & varible from $\mathrm{f} / \mathrm{g}$ to $\mathrm{c} / \mathrm{g}$ cpxt with fo stained sipd olivine & of & 30 & 0 \\
\hline 3162 & $\mathrm{H}-14$ & $387-392$ & & & & ve/g cpxt with sparce fo stained srpd olivine patches p & 0 & 10 & 0 \\
\hline 3163 & $H=14$ & $392-398$ & & & & vc/g cpxt with sparce fo stained srpd olivine patches of & 0 & 0 & 0 \\
\hline 3164 & $\mathrm{H}=14$ & $398-403$ & & & & vc/g cpxt with sparce fe stained sipd olivine patches pf & of & 25 & 0 \\
\hline 3165 & $\mathrm{H}-14$ & $403-411$ & & & & ig to $\mathrm{m} / \mathrm{g}$ amphiobolized pyroxenite f/g sulfide diss in $\mathrm{f}$ & 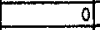 & 10 & 8 \\
\hline 3047 & $\mathrm{H}-15$ & $470-500$ & & & & C-120 composit rejects & of & 40 & 0 \\
\hline 3166 & $\mathrm{H}-15$ & $479-490$ & & & & black to greenish vc/g duniteto wher lite varibly sipd of & of & 5 & 0 \\
\hline 3167 & $\mathrm{H}-15$ & $490-500$ & & & & black to greenish vcig duniteto wherlite varibly srpd of & 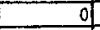 & 30 & 0 \\
\hline 3168. & $\mathrm{H}-15$ & $500-510$ & & & & black to greenish ve/g duniteto wherlite varibly sipd of & of & of & 0 \\
\hline 3210 & $H-15$ & $539-549$ & & & NEW SAMPLE & m-c/g srpd talk altered clinopyroxenite & & & \\
\hline 3169 & $\mathrm{H}-15$ & $549-555.5$ & & & & varible t/g to vc/g clinopyroxenite sheared and crushe, & of & 10 & 0 \\
\hline 3048 & $\mathrm{H}-15$ & $549-637$ & & & & C-122 composit rejects & of & 65 & 0 \\
\hline 3171 & $\mathrm{H}-15$ & $555.5-565$ & & & & varible f/g to ve/g clinopyroxenite sheared and crushef & 0 & 25 & 0 \\
\hline 3170 & $\mathrm{H}-15$ & $565-570$ & & & & varible f/g to ve/g clinopyroxenite sheared and crushes & 0 & 5 & 0 \\
\hline 3172 & $\mathrm{H}-15$ & $570-575$ & & & & t/g dunite layer $\mathrm{tm} 570-575+90 \%$ brn-blk ofivine + fing & of & 65 & 0 \\
\hline 3173 & H-15 & $575-581$ & & & MAGKC-PULP & $\mathrm{v} / \mathrm{c} / \mathrm{g}$ clinopyroxente xtalls to $+1^{\prime \prime} 3^{\prime}$ feldspar dike at 57 & 0 & 70 & 6 \\
\hline & $H-15$ & 578.5 & $\mathrm{H}-15-578.5$ & & & Ksp Qtz Chl dike & & & \\
\hline 3174 & $\mathrm{H}-15$ & $583-588$ & & & & $\mathrm{c} / \mathrm{g}$ to $\mathrm{v} / \mathrm{c} / \mathrm{g}$ wherlite brn olivine xtalls + green cps stalls & of & 15 & 0 \\
\hline 3214 & $\mathrm{H}-15$ & $588-594.5$ & & & NEW SAMPLE & wehrlite cpx/oliv mix varible amts $\mathrm{m}$-c/g hi mag & & & \\
\hline 3211 & $H=15$ & $594.5-599$ & & & NEW SAMPLE & magnetite wehrlite to cpxt wt dnt layer. & & & \\
\hline 3212 & $H-15$ & $599-604$ & & & NEW SAMPLE & Dunite to c/g cpxt low mag & & & \\
\hline 3175 & $\mathrm{H}-15$ & $604-614$ & & & & c/g dunite to wher hite with patches of v/c/g cpx with $2^{n}$ & 0 & 245 & 의 \\
\hline 3213 & $\mathrm{H}-15$ & $614-618$ & & & NEW SAMPLE & c/g clinopyroxenite low mag & & & \\
\hline 3176 & $\mathrm{H}-15$ & $618-622$ & & & & $\mathrm{v} / \mathrm{c} / \mathrm{g}$ green clinopyroxenite xtalls to $+1^{4}$ & of & 60 & 0 \\
\hline 3177 & $H+15$ & $622-627$ & & & MAGIC-PULP & $\mathrm{v} / \mathrm{c} / \mathrm{g}$ wherlite to $\mathrm{m} / \mathrm{g}$ brn-black olivine rich dunite & of & 595 & 4 \\
\hline 3178 & $H=15$ & $627-632$ & $H-15-630$ & & & o/g dunite to wherlite wi fresh brn-bik olivine + varble a & 0 & 120 & 0 \\
\hline 3215 & $H+15$ & $632-637$ & & & NEW SAMPLE & $f-m / g$ wehnrite to dunite varibly magneticgray dike at 633 - & $3-634.5$ & & \\
\hline
\end{tabular}




\begin{tabular}{|c|c|c|c|c|c|c|c|c|c|}
\hline Sample\# & Hole & Depth & $T / S$ & W/R & RECOMMENDATIONS & Note & $A u(p p b)$ & $P t(p p b)$ & Pd $(p p b)$ \\
\hline 6625521 & $\mathrm{H}+15$ & $632-637$ & & & Assmt ck sample & v/cg cpxt + oliv cut by and diks & $<0.001$ & 0.074 & 0.005 \\
\hline 3016 & $\mathrm{H}-16$ & $266-76$ & & & & perv arg alt leached and bleached int? & 0 & 0 & 4 \\
\hline 3017 & $\mathrm{H}-16$ & $276-86$ & & WR & MAGIC-PULP & perv arg ait leached and bleached int? & 0 & 0 & 8 \\
\hline & $\mathrm{H}-16$ & 303 & $\mathrm{H}-15-303$ & & & Pery sil around $k$-spar quartz vein & & & \\
\hline 3018 & $\mathrm{H}-16$ & $305-307$ & & & MAGIC-PULP & str alt sil ti mn stained arg alt seds & 0 & 0 & 18 \\
\hline 3019 & $\mathrm{H}-16$ & $309-311.5$ & & & & OQ/K-sp/Bio vn in perv sil seds & 0 & 0 & 0 \\
\hline 3020 & $\mathrm{H}-16$ & $512-515$ & & & & varib sil \& hrn $+=$ ser + tr Cpy & 0 & 0 & 6 \\
\hline 3021 & H-16 & $555-59$ & $H-16-559$ & WR & & varib sil $\& \mathrm{hrn}+=s e r+$ hrin otz tr Cpy & 0 & 0 & 10 \\
\hline 3022 & $\mathrm{H}-17$ & $385-390$ & & & & oxidized pyx cuttings & 16. & 45 & 18 \\
\hline 3179 & $H=17$ & $390-395$ & & & & oxidized pyx cuttings & 0 & 10 & 18 \\
\hline 3023 & $\mathrm{H}=17$ & $395-400$ & & & & oxidized pyx cuttings & 2 & 15 & 18 \\
\hline 3180 & $\mathrm{H}-17$ & $400-405$ & & & & oxidized pyx cuttings & 0 & 10 & 12 \\
\hline 3024 & $\mathrm{H}-17$ & $405 \cdot 410$ & & WR & & oxidizad pyx cuttings & 2 & 40 & 42 \\
\hline 3181 & $\mathrm{H}-17$ & $410-415$ & & & & oxidized pyx cuttings & 0 & 15 & 6 \\
\hline 3049 & $H-17$ & $460-530$ & & & & C-111 composit reject of Cuttings?? & 4 & 5 & 8 \\
\hline 3025 & H-17 & $460-65$ & & & & weathered py $x$ sand cuttings & 8 & 0 & 8 \\
\hline
\end{tabular}




\title{
KEMUK MOUNTAIN IRON ORE PROSPECT DILLINGHAM DISTRICT, ALASKA
}

\author{
By William J. Whaley, Jr. \\ Richard A. Bray
}

November, 1959

Report for Humble Oil and Refining Co. 
$\varepsilon P R * 7393$

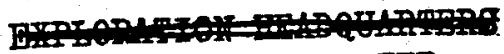

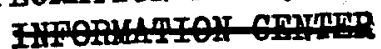 \\ Poox mage}

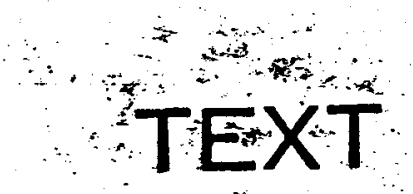

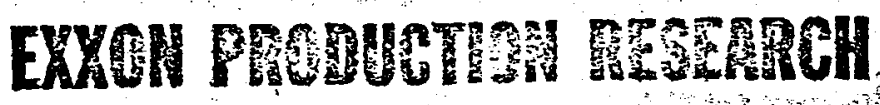 REFORTS SECHOH}
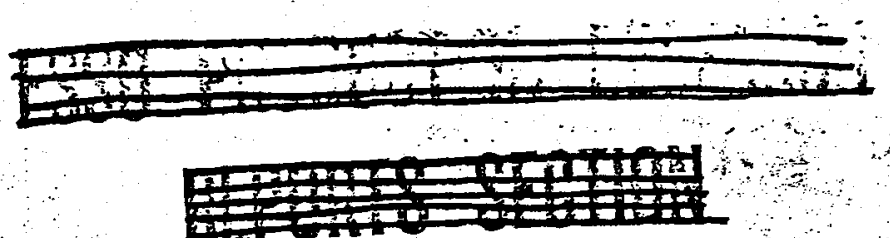

,

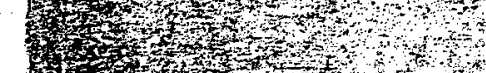


EXON COMPANY, U.S.A.

MEMORANDUM

TO: P. S. DAVIDSON

FROM: $\quad$ M. N. SLATER

SUBJECT: $\quad$ KEMUK MOUNTAIN PROPERTY SOUTHWESTERN ALASKA

DATE: $\quad$ SEPTEMBER 27,1977

At the request of Tom Barrow during our review on $8 / 3 / 77$, I contacted Edward T. Miller and Richard A. Bray who were project geologists at Kemuk Mountain. I then located and obtained the report entitled "Kemuk Mountain iron ore prospect, Dillingham district, Alaska" by W. J. Whaley and R. A. Bray. B. E. Kilpatrick has reviewed this report and his sumary and recommendations are attached.

Bruce recommends no further work on this prospect because of the low grade magnetite mineralization and the paucity of base metal sulfide potential. The core was scrutinized very carefully and any trace amounts of copper mineralization noted were assayed for copper. The highest copper assay was $0.17 \% \mathrm{Cu}$. The core was not assayed for nickel, chromite or platinum group metals which characterize wel1-layered cratonic mafic-ultramafic bodies and are common in alpine ultramafic complexes. The fact that the careful examination of the core revealed no significant sulfide accumulations suggests that little potential exists for the above metals even if the sulfide type was misidentified. Several other magnetite rich, alpine ultramafic complexes are known in southern Alaska and these are also characterized by very low base metal content. Finally Turam and AFMag surveys were conducted over the Kemuk Mountain property in an attempt to locate sulfide concentrations. The results of these surveys were negative but it should be pointed out that the thickness of the overburden $\left(+200^{\prime}\right)$ probably rendered these techniques useless.

The attitude of the ultramafic complex remains a point of conjecture but I tend to subscribe to Bruce's interpretation that the layering is steeply west dipping. This layering may be more apparent than real, however, because the Kemuk complex is a Cretaceous alpine type and the "layering" may be the result of tectonics and intrusive episodes rather than true magmatic layering characteristic of the large, Precambrian, cratonic ultramafic complexes (e.g. Bushveld complex, Duluth gabbro, and Stillwater complex).

The potential remaining at Kemuk Mountain is finding base metal sulfide accumulations at the base of the ultramafic complex. We consider this a long shot at best because of the low sulfide content drilled to date, the Cretaceous age (rather than Precambrian), the alpine nature (rather than cratonic) and the 
MNS SEPTEMBER 27, 1977 P. 2

absence of significant sulfides in other similar ultramafic complexes in southwestern Alaska. We recommend no additional work at Kemuk Mountain.

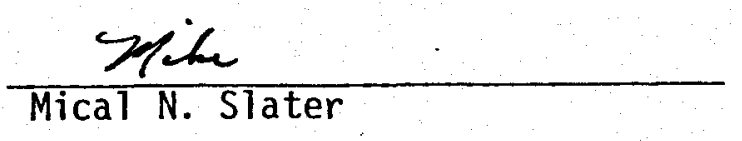

MNS :rc

Enclosures 

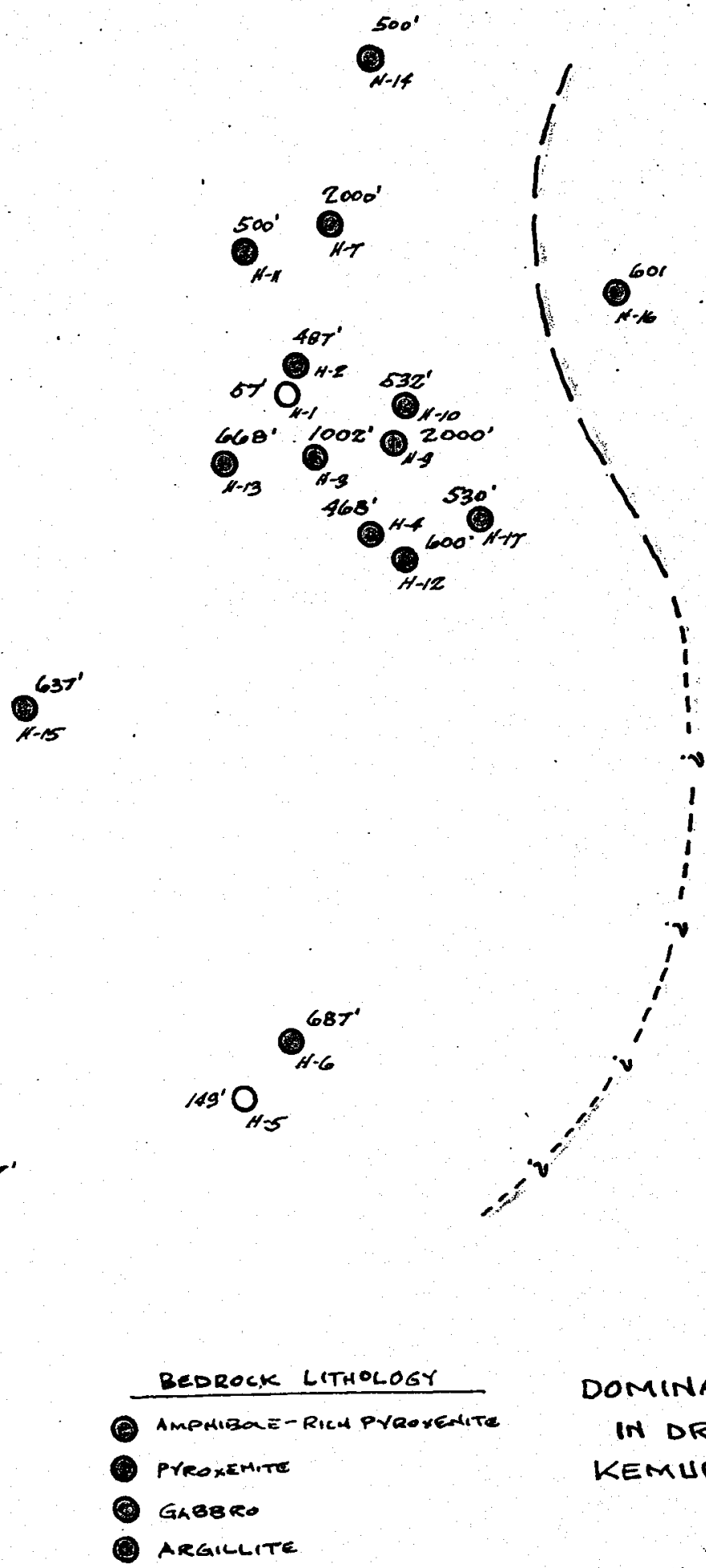

DOMINANT ROCK TYPE

IN DRILL HOLES KEMUK MOUNTAIN

ALASKA

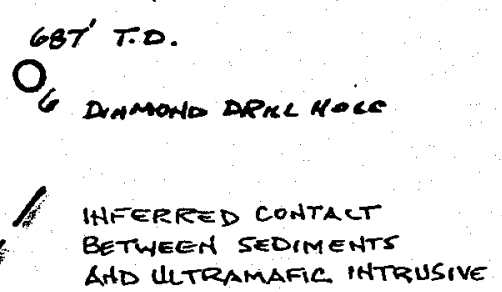

SCALE: 1 IM. $=5000 \mathrm{FT}$. 


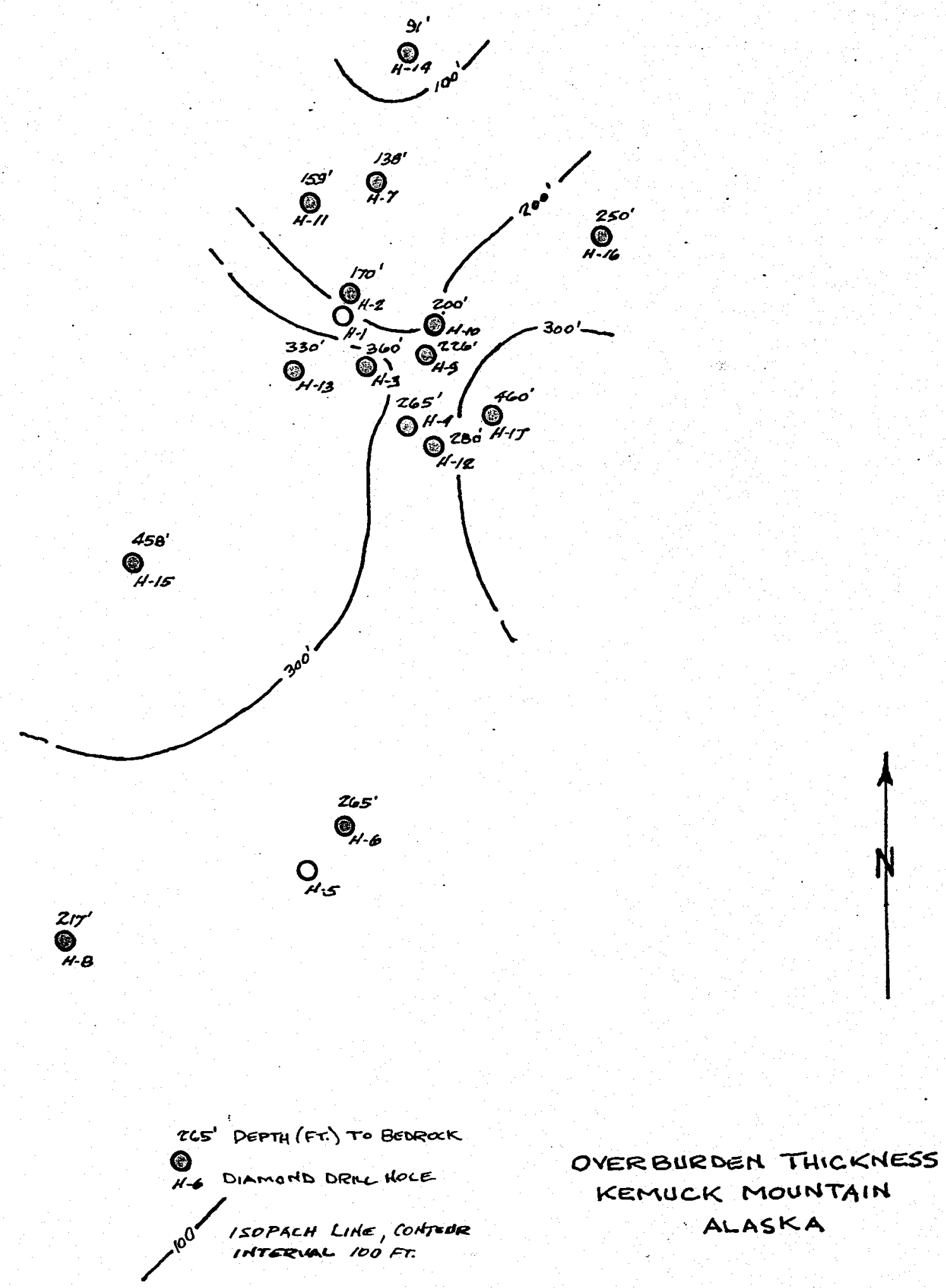

SCALE: $1 \mathrm{HH}=5000 \mathrm{FT}$. 

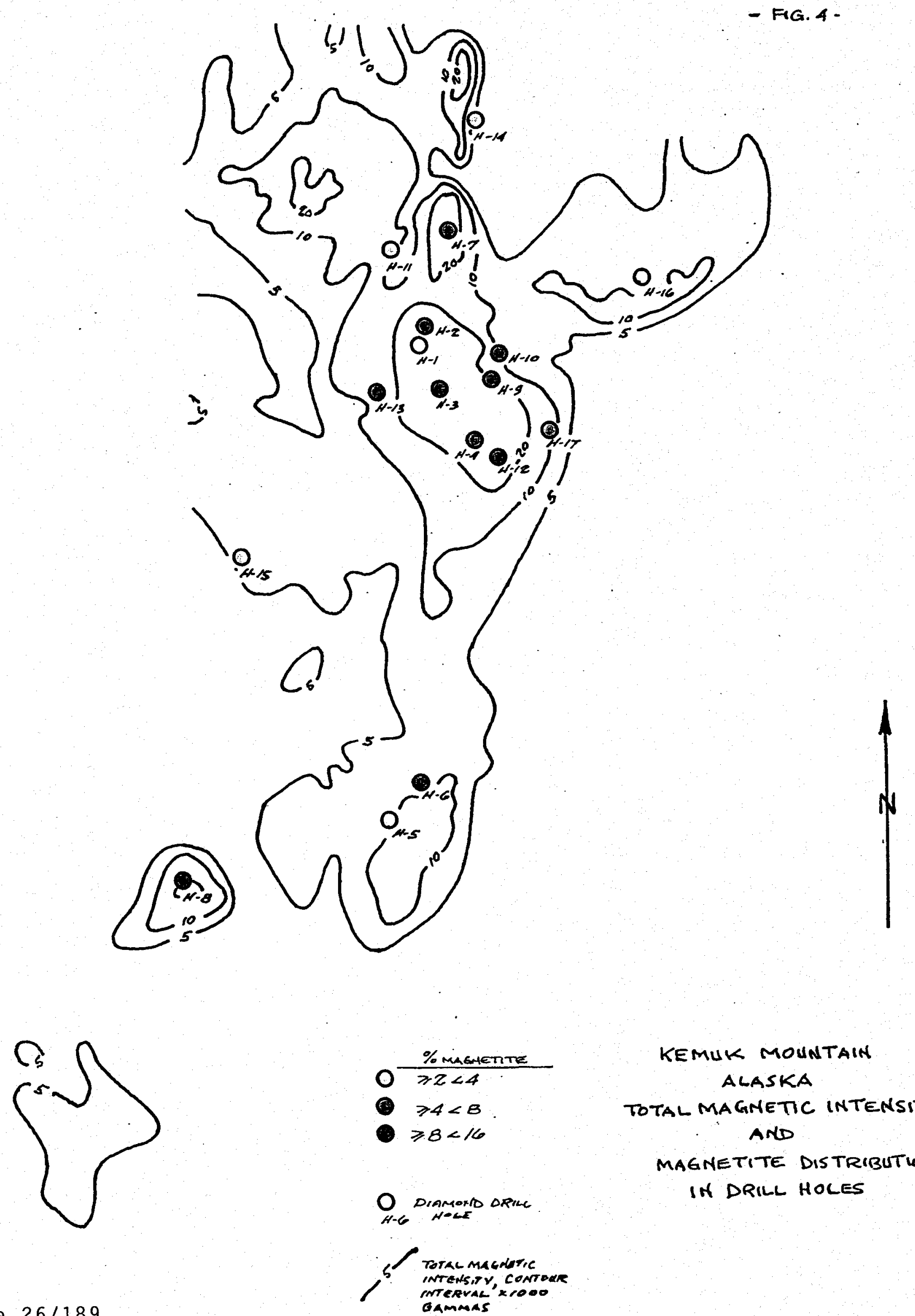

KEMUK MOUNTAIN ALASKA

TOTAL MAGNETIC INTENSITY AND

MAGNETITE DISTRIBUTION IN DRILL HOLES

Page $26 / 189$

SLALE: $1 \mathrm{HN}=5000 \mathrm{FT}$.

- GMC DATA REPORT 355 RE.K. $9 / 77$ 


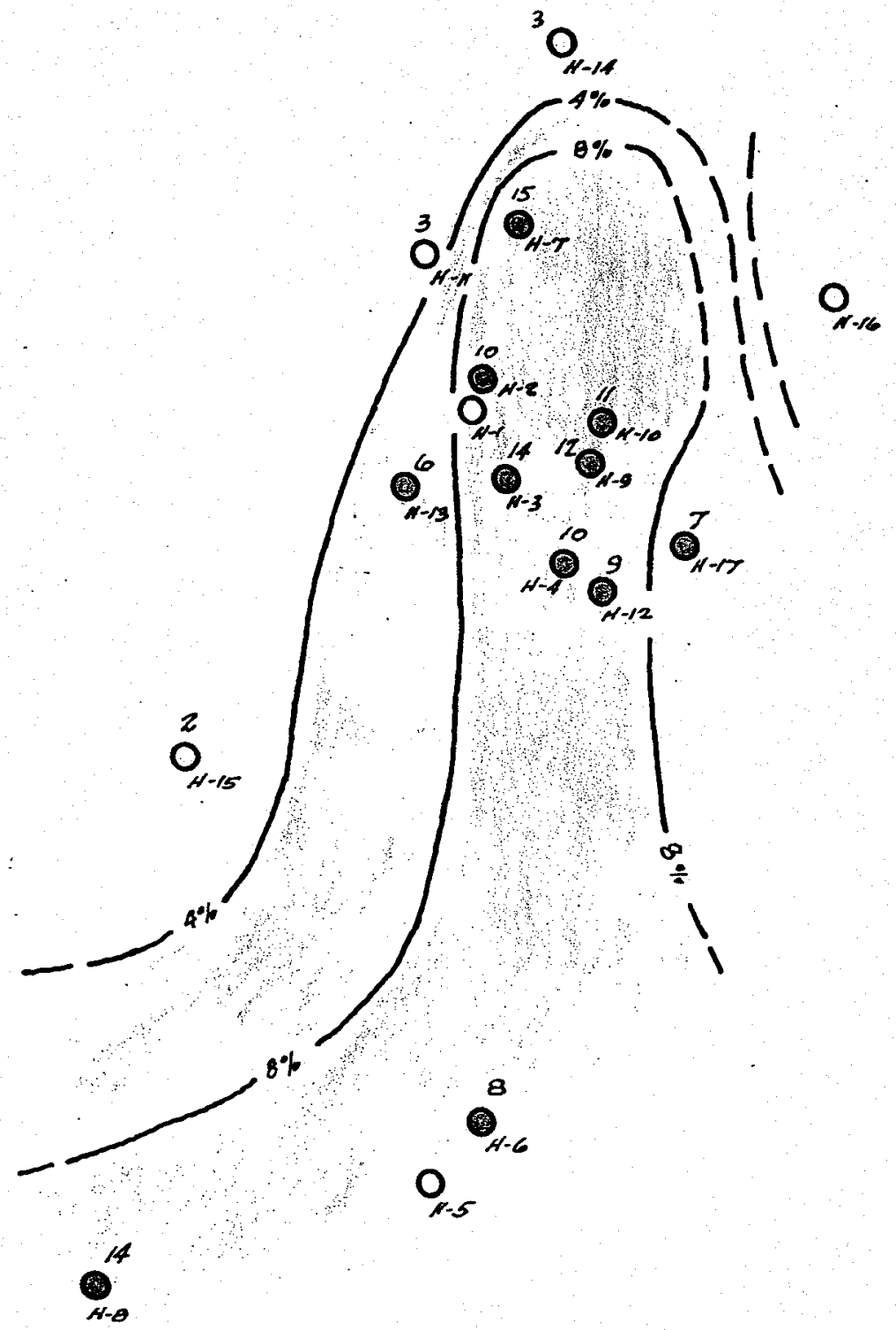

\% magnetite

$0 \geqslant 2<4$

(i) $\geqslant 4<8$

(2) $\geqslant 8<16$

MAGNETITE DISTRIBUTION

IN DRLL HOLES

O \% MAGNETITA
H-6 DIAMOND DRILC
HOLE

KEMUK MOUNTAIN

ALASKA

SCALE: I IH.= S000 Fr. 

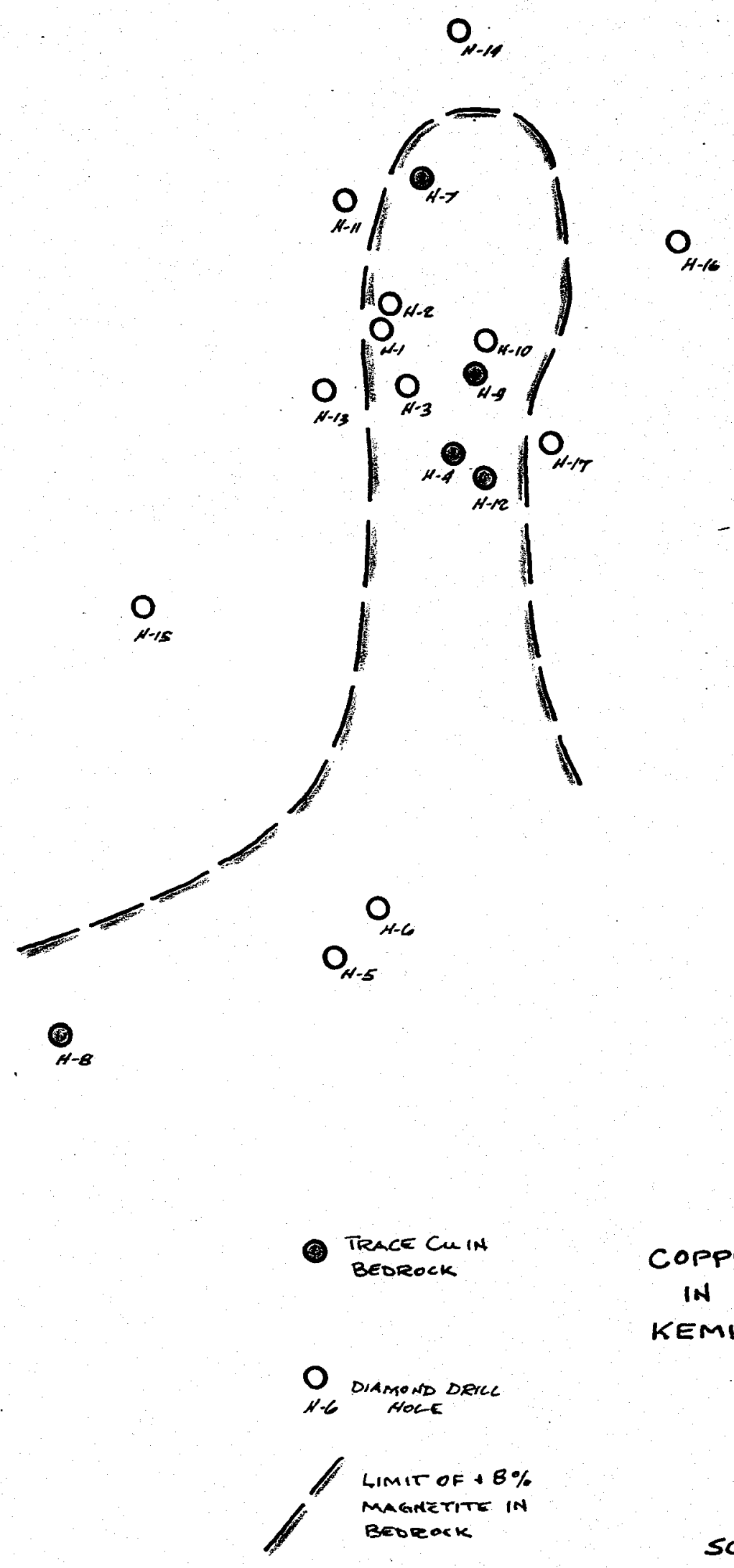

COPPER OCCURREACE IN BEDROCK KEMUK MOUNTAIN ALASKA

SCALE: $1 \mathrm{lH} .=5000 \mathrm{FT}$. 
Page

ABSTRACT .

Iv

INTRODUCTION

Location of Area and Geologic Setting ........... 1

Project Histary or Background . . . . . . . . . . 2

1957 Discovery

Tumary of 1958 Work $\ldots \ldots \ldots . . . . . .2$

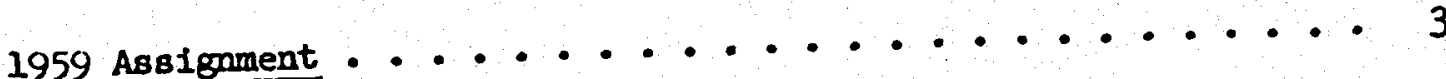

REPORT ON 1959 EXPLORATION . . . . . . . . . . . . . 4 Methods of Operation ................. 4

Logistics

Technical Organization and Equipment .......... 7 Geophysics .............. 7 8

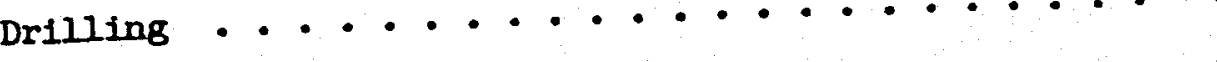
Sample analysis ............... 8 Electric logging ....................... 10 Ceophysical 10 .... 10 $\ldots \ldots \ldots 11$ Refraction seismograph ........... 13 $\ldots \ldots \ldots 13$ Drilling . 


\section{IILUSTRATIONS}

TABLE

Following

Page

I Assayed and calculated iron content of significant

drill hole intercepts . . . . . . . . . . . 14

PLATES

I Location Map of the Humble Clatm Area $\ldots \ldots \ldots \ldots$

II Geologle Map of the Nushagak RIver Basin . . . . . . I

III Photographs . . . . . . . . . . . . . 4

Figure 1 Photograph of the 1959 fleld camp . . . . . . 4

Figure 2 Photograph of Longrear's Model 44 drill ris. on location at the H-13 site ........ 4

IV-A Drill Hole Location Map . . . . . . . . . 13

IV-B Pre-glacial Topographic Map ............. 13

IV-C Magnetic Intensity Anomaly Map ............ 13

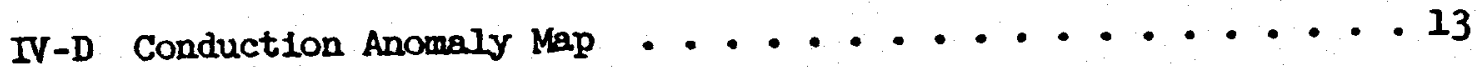

IV-E Magnetite and Copper Occurrence Map . . . . . . . . 13

v Typical Resistivity-Specific Gravity Logs . . . . . . 17

Figure 1 Drill Hole 11 . . . . . . . . 17

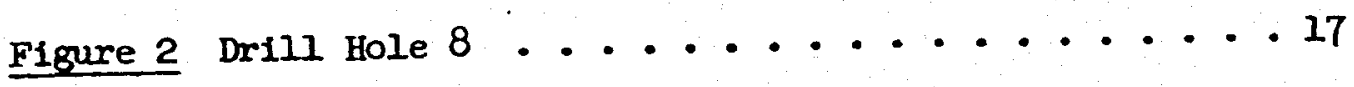

VI East-West Geologic Cross Section (Foldout) . . . . . 23

VII North-South Geologic Cross Section (Foldout) . . . . 23

VIII Claims Recommended for Patenting . . . . . . . . 26

IX Map of Pre-glacial Geology with Significant Drill

Hole Intercepts ............. (In Pocket)

PACKET

Widco Electric Logs ........... (In Pocket) 
ABSTRACT

The Kemuk Mountain Iron ore ancmaly was discovered in 1957 by aerial mognetometer surveys conducted over the Nushagak Basin in soutbwestern Alaska. Th1s magnetic anomaly 18 caused by an ultrabasic igneous complex, not unlike several intrusive bodies discovered along the southeastern cosst of Alaska, some of which due to their ready accessibillty are being developed by a subsidiary of U.S. Steel Company.

In 1958, 815 lode and placer claims were staked over the anomaly by Humble and ground magnetometer surveys were completed. During the sumer months of 1958 and 1959, fourteen of a total of seventeen core tests that were drilled encountered the intrusive. The intrusive is overlain by glacial fill material to depths varying from 90 feet to 460 feet. Magnetite was discovered in percentages of 2 to 35 percent with the greatest concentration in a phase of the intrusive which 18 classified as magnetite pyroxenite. The mogetite content averages 14.5 to 16.5 percent in the western part of the magnetite pyroxenite mass, and 10.5 to 12 percent in the eastern part. Traces of native copper, chalcopyrite, and sphalerite were noted; however, extensive electromagnetic surveys completed in 1959 falled to detect anomalles which might suggest comercial deposits of copper or other base sulfides.

Laboratory analyses indicated that the relatively low content of magnetite in the ore body would require high concentration ratios that would preclude a commercially competitive mining operation at this time. It is recommended, therefore, that Humble conduct no further exploration work for its own account in the prospect area. There remains one untested possibility of magnetite enrichment, however, along the western margin of the intrusive. Since several Iron-ore mining firms have expressed interest in the prospect, every effort should be made to retaln the claims until it is learned whether or not the property can be farmed out for additional exploration. 


\section{KEMUK MOUNTAIN IRON ORE PROSPECT \\ DILCINGHAM DISTRICT, ALASKA}

\section{INTRODUCTION}

\section{Location of Area and Geologic Setting}

The Humble Claim area is located about 55 airline miles northeast of Dillingham, Alaska, at approximately $59^{\circ} 45^{\prime}$ north latitude and $158^{\circ} 15^{\prime}$ we st longitude (Plate 1 ).

The area lles on a lowland plain of unconsolldated fluvial-glacial sediments deposited as outwash from the quaternary glaciation of the Tikchik and Wood River Mountains west of the lowland. The ultrabasic Intrusive which is the prime concern of this report is burled beneath 90 to 460 feet of these sediments.

The glacial-sculptured Tikchik and Wood River Mountains are formed primarily of Cretaceous sediments, with one area of Mississippian (?) Bediments and Permian (?) greenstone in their northern portion, one small patch of Triassic limestone on the south shore of Nuyakuk Lake (Bertie, 1938) and scattered granitic to monzonitic batholiths and stocks which are probably late Cretaceous to early Tertiary in age (Plate II). Cretaceous sediments also crop out nortbeast of the claim area in Ketok Mountain and in the low, rounded Nushagak Hills. East of the Nushagak and Mulchatna Rivers is an area of Quaternary-Tertiary lavas and tuffs whlch probably interfinger westward into the lower part of the fluvial-glacial deposits (Geophoto's Alaska Report No. 17, 1957). The nearest outcrops to the claim area are the granitic prominence 


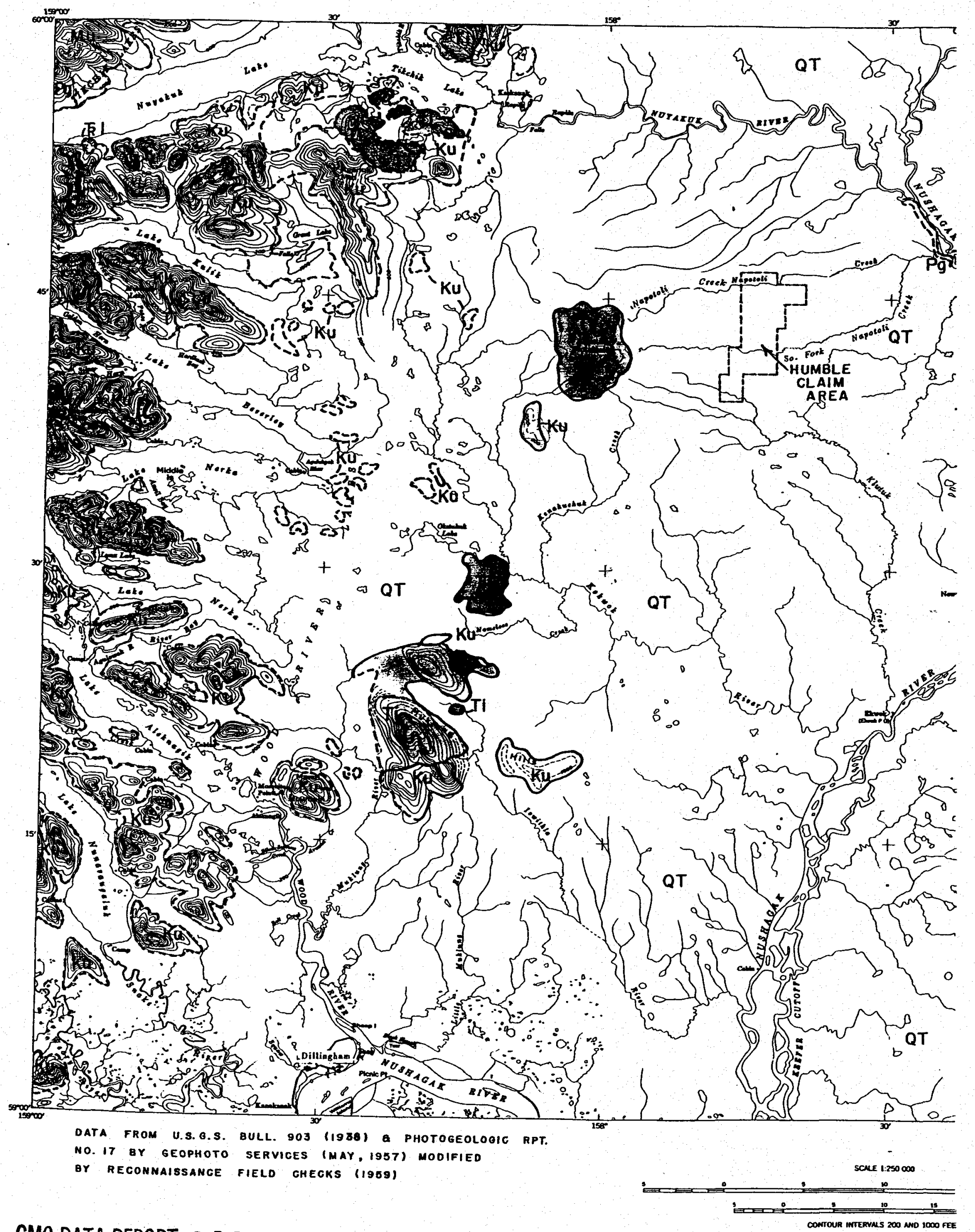




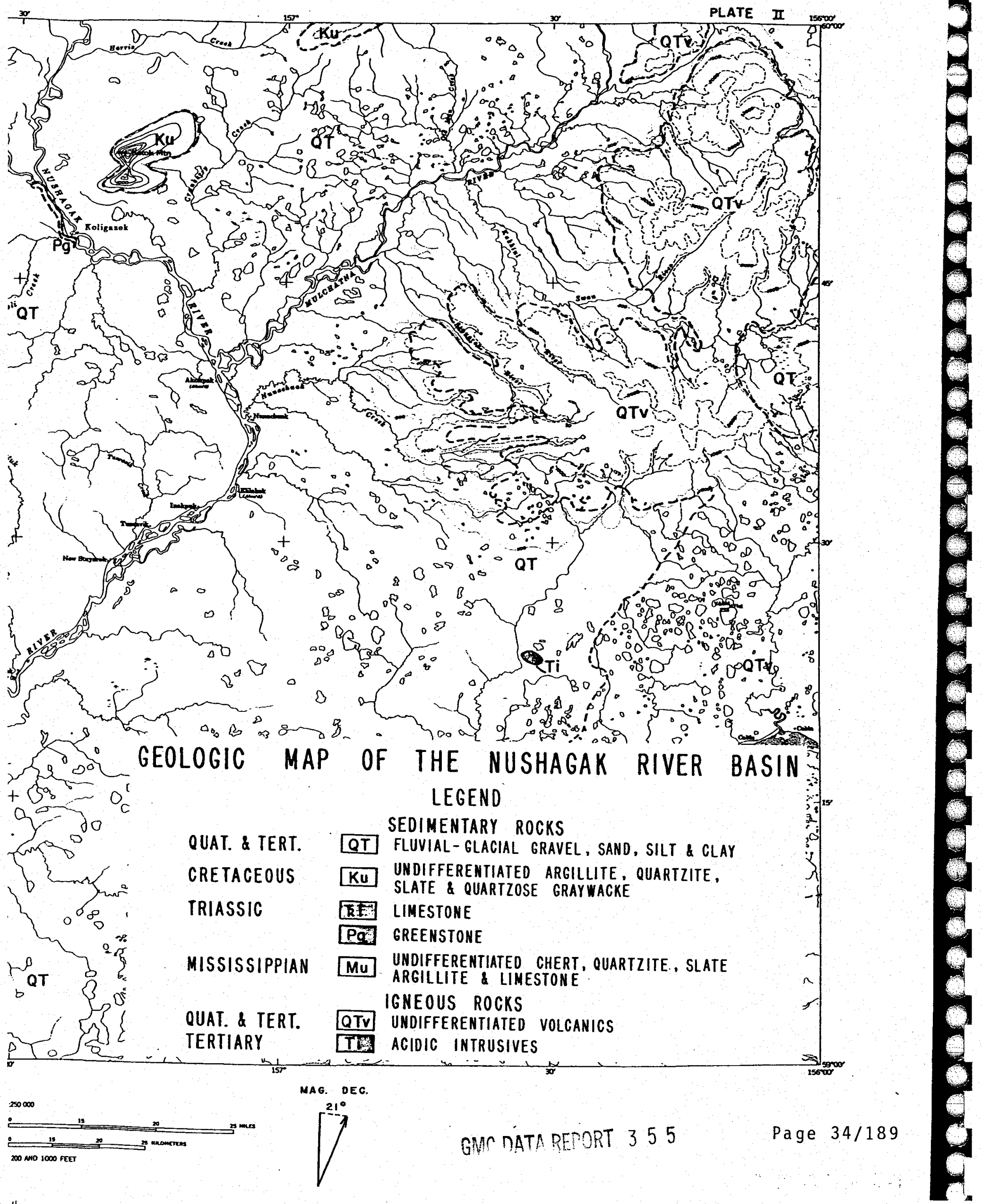


which forms Kemuk Mountain, and scattered patches of Permian (?) greenstone along the west bank of the Nushagak River about 12 miles east of the claim area.

The investigated intrusive is a complex of the following genetically related rock types: pyroxenite, mognetite pyroxenite, gabbro, and andesite (see pagel7 for definitions). Economic interest centers on the magnetite pyroxenite.

\section{Project History or Background}

\section{Discovery}

The Aero Service Corporation of Philadelphia, Pennsylvania, conducted an aerial magnetometer survey of the liuskagak Essin for Humble in 1957. As a result of this survey, a large magnetic anomaly was discovered near Kemuk Mountain. Preliminary interpretation of this anomaly postulated that a rather extensive magnetite deposit was present and further investigation warranted.

Sumary of 1958 Work

In June, 1953, Humble conducted a series of ground magnetometer surveys over, and adjacent to, the main magnetic anomaly. This work confirmed the general outline and intensity of the airborne anomaly and resulted in the decision to initiate a core drill program. In July, 1958 , a small crew of civil engineers staked approximately 75 claims over the main magnetic feature. At the same time, a small seismic shot hole $\mathrm{rig}$ was flown into the area for the purpose of drilling a core hole. Unfortunately, this rig was unable to penetrate the glacial gravels that were encountered. After this preliminary failure, the project was suspended and all evidence of claim staking was removed. 
with electromagnetic equipment was arranged for the purposes of detecting base sulfides, primarily copper, and of implementing the search for more concentrated sources of magnetite.

Initially, three core tests were to be drilled while the geophysical date vere belng acquired. These tests were located on magnetic anomalies which had not been tested the previous year. Two of these locations, $H-7$ and $H-9$, were to be drilled to 2,000 feet to determine if magnetite percentages increased with deptb. The electromagnetic results were to be utilized in selecting any subsequent drill locations.

REPORT ON 1959 EXPLORATION

Methods of Operation

Carme

The basic camp equipment was flown by hellcopter to the claim area. on May 23, 1959, and actual erection of the camp facilities began on that date. The camp was ready to accomodate the 21 drilling and geophysical personnel when they arrived on May 31. The camp was located on a high bluff overlooking the south fork of Napatoll Creek, a tributary of the Nushagak River (see Plate III, Fig. 1). This site was adjacent to the east-central part of the claim block, affording rapid access to any portion of the claim area by helicopter. Living quarters consisted of seventeen $10^{\prime} \times 10^{\prime}$ PortaKamp units capable of housing 34 men. Two 10' $X 20^{\prime}$ Porta-Kanp units, pleced back to back, formed a $10^{\prime} \times 40^{\circ}$ kitchen and dining room facility. Insulated cots and sleeping bags furnished comfortable sleeping arrangements. Coleman Heatmssters were adequate for providing warmth within 
PIATE III.

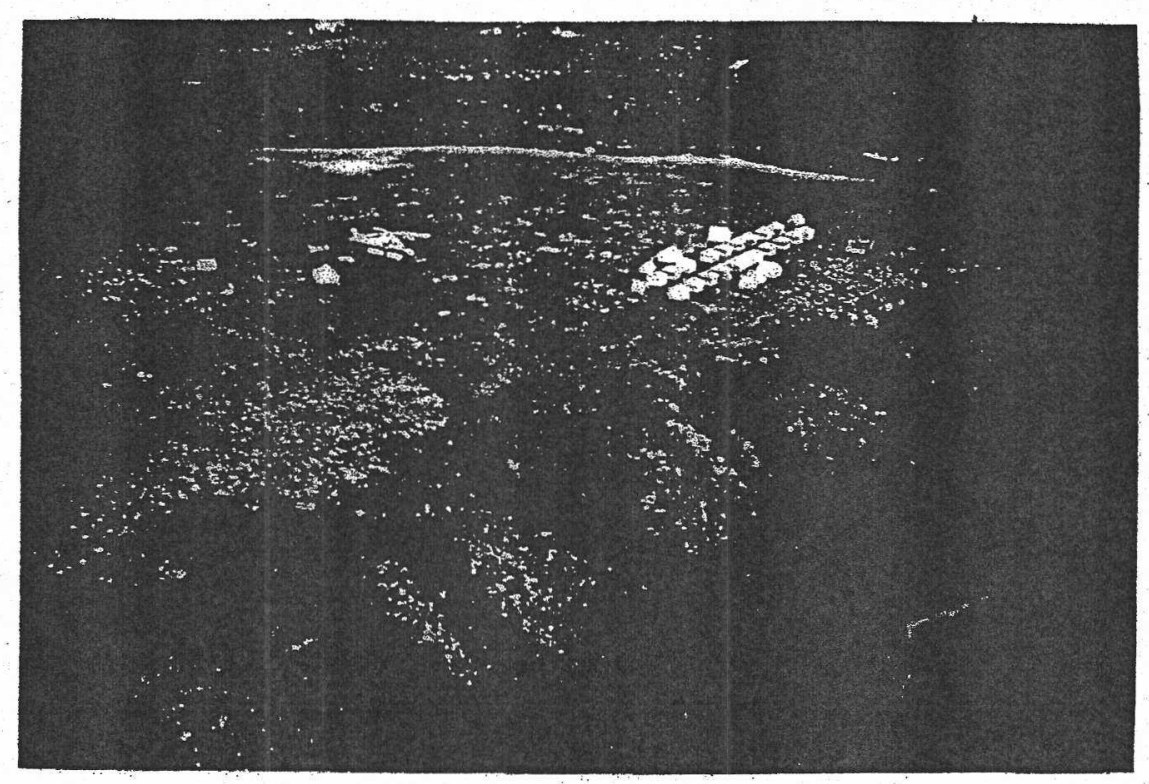

Figure 1. Photograph of the 1959 fleld camp

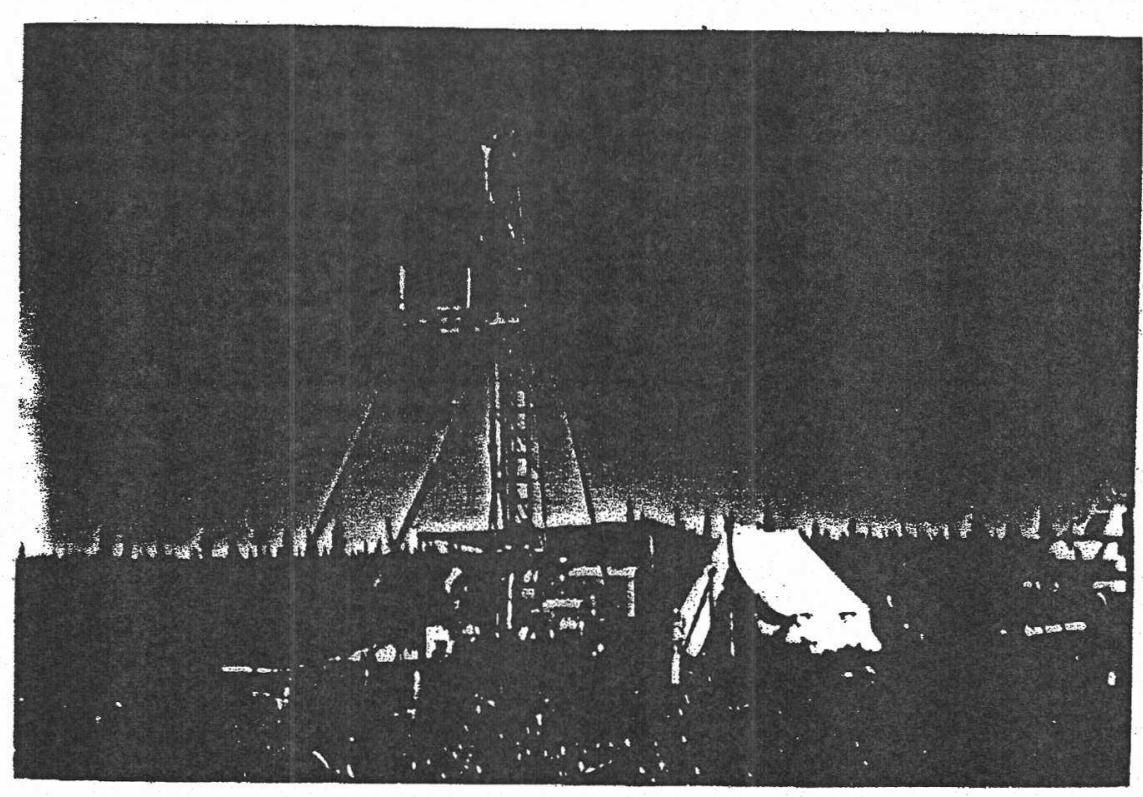

Figure 2. Photograph of Longyear's Model 44 Drill rig on location at the $\mathrm{H}-13$ site. 
the tents and for beating water in the shower and kitchen units. Fifteen canvas tents of varlous dimensions were utilized for general storage, washroom, tollet, core processing, and generator installations.

Camp personnel consisted of the following men:

1). E. J. Longyear Campany (16)

6 drillers

6 belpers

1 drill foreman

I Sr. counsel (2 veeks in camp)

1 engineer - geologist

1 core splitter

2). Hunting Technical \& Exploration Sexvices, Ltd. (6)

$3 \mathrm{Jr}$. operator technicians

1 Sr. operator

1 Jr. geophysicist

$1 \mathrm{Sr}$. geophysicist (2 weeks in camp)

3). Rotor Alds (6)

3 pilots

3 mechantcs

4). Universal Services (5)

1 cook

1 essistant cook

3 camp belpers

5). Humble (2)

1 geologist

1 coordinator and project supervisor

Universal Services of Seattle, Washington, furnished the cooks and camp helpers who performed the housekeeping and maintenance dutles around the camp. 
Outside radio communication was maintained by means of a 100-watt Northern radio-telephone that was leased for the summer. Radio contact between the camp and the drill rigs was accomplished by Motorola FM sets furnished by Humble's Geophysics Research Section. Two gasoline Onan generators of $3 \mathrm{kw}$ capacity furnished electric power for the camp.

\section{Logistics}

The major portion of the material and equipment assigned to this project was assembled at Seattle, Washington, and shipped from there to Naknek, Alaska, by an Alaska Frelght Lines barge. At Naknek, the cargo was transferred to river barges and shipped up the Nushagak River to the village of Ekwok, located 25 miles south of the campaite. The material was then . ferried to the camp area by two Company-owned $5-58$ helicopters.

The town of Dillingham was the nearest point with scheduled commercial afrline service. Incoming passengers, mall and supplies were transported from Anchorage to Dillinghom by Northern Consolidated Alrlines. They were then transferred to float or amphibian aircraft and flown to a amall lake situated 10 miles northeast of the clasm area, from which they were brought to the camp by helicopter. The helicopters served as the sole means of transport of personnel and equipment around the claim block. Upon the completion of the project, the equipment and remaining supplies were loaded aboard a river barge at the village of Kollganek and shipped down the Nushagak River to DIllingham. There the material was received by the Alaska Steamship Company which transported a portion of the cargo to Seward and the remainder to seattle. 
Technical Organtzation and Equipment

Geophysics - The Hunting Technical and Exploration Services, Ltd., of Toronto, Cansda, was contracted to conduct a serles of electrical conductivity surveys utilizing the Afmag and Turam methods. Briefly, the Afmas Instrument measures the plane of polarization of the audio frequency component of the earth's magnetic fleld. This varying fleld is thought to be generated by distant thumderstorms. These audio frequency components are normally polarized in a horizontal plane but are distorted in the presence of a conducting body, such as magnetite, graphite, a base sulfide, or a water course along a fault zone. By measuring such distortions, the Afmag is able to determine the position and size of the conducting body. The Afmag method is generally utilized in a reconnalssance survey.

The Turam unit measures a magnetic fleld created by passing an alternating current through a large horizontal loop or a grounded cable. A amall portable generator is employed to produce the current. The magnetic field $1 \mathrm{~s}$ distorted in the presence of a conducting body and components of this distortion are measured by the Turam instrument. This method is used in a detalled survey, since readings must be made at rather small intervals.

In addition to this primary function, Hunting provided a Sharpe A-2 magnetometer and a small Ronka direct-reading refraction selsmograph unit for use where varranted.

Hunting's organization consisted of two fleld crews of two men each and one party chief. The party chief was responsible for interpreting the fleld observations, planning field procedure and recommending anomalous features for drill locations. One fleld crew member was classed as a senior operator and was responsible for equipment malntenance and field supervision. 
Drilling - The E. J. Longyear Company of Minneapolls, Minnesota, was again contracted to conduct the core driling program. Longyear was responsible for furnishing two drill units and the personnel to operate them. In addition, an engineer-geologist was furnished to prepare the diamond drill core for analysis, compile the final assays and lithologic descriptions, and submit recommendations relative to the location of drill sites.

Longyear provided two hydraulic gasoline-powered rigs of its own design (see Plate III, F1g. 2). The smaller untt, the Junior Straitline model, which had been beld over from the 1958 work, is capable of drilling to 1,200 leet. The Model 44 unit was designed for depths down to 3,000 feet. The Model 44 rig was equipped ifth a wire-line core barrel which alded both core recovery and drilling progress.

Rock bits and drilling mud were used to drill through the glacial overburden. When ledge (bedrock beneath the fluvial-glacial f1ll) was encountered, casing was set, and a diamond core bit installed to core the bedrock. Fresh water replaced the drilling mud when coring operations began.

The rigs operated on a 24-hour-a-day, 7-day-a-week drlliling schedule. Three 8-hour work shifts vere used; each crew was comprised of a driller and a belper. Longyear provided one drill foreman to supervise the drilling personnel and to oversee the maintenance of the rigs.

Sample analysis - Core was subjected to a three-phase fleld analysis: determination of magnetic polarity and Intensity, visual exam1nation, and measurement of specific gravity for estimation of magnetite content. 
Magnetic polarity and intensity were readily determined with a Brunton compass. Visual examination was by hand-lens, and the observed mineralogic, textural, and structural features were complled in lithologic loge (Appendix A). Speciflc gravities were measured by means of a beam balance and graduated cylinder.

Visual estimation of magnetite content was found to be impractical, and fleld estimates were based on the specifle gravity of the core. Curves. for determination of magnetite content from specific gravity were progressively corrected as assay data were received. The later, most accurate curves assumed a specific gravity of 5.1 for magnetite and 3.3 for the average gangue.

After fleld examination and description, the core was split lengthwise. One-half was shipped to Humble's Research Center in Houston and the remaining portion was sacked according to drill "runs" and shipped to the H. T. Caddy laboratories. Caddy prepared composite samples of 50-foot Intervals and assayed them for total iron content. Selected composites and Individual samples were subjected to magnetic iron-concentration tests with a Davls magnetic tube. Samples for selected intervals vere also assayed for copper, zinc, titania, and cobalt.

A cursory petrographlc study was made by Richard Bray of each of the rock types encountered in the intrusive. J. D. Martinez and Alex Frasch of Humble's Research Section measured the magnetic properties of selected samples, and Vernon Porter, also of the Research Section, conducted spectrographic tests on six core samples. 
Electric logging - a portion of all the drill holes, wth the exception of $\mathrm{B}-15$ and $\mathrm{B}-17$, was logged electrically by means of a Widco logging unit. This unit, built by the Well Instriment Developwent Corporation of Houston, Texas, was designed for depths to a thousand feet. For our purpose, the instrument was modified so that depths to 2,000 feet could be logged. The Widco untt furnished both a resistivity and self-potential curve. (See electric logs in Pocket).

\section{$\underline{\text { Results }}$}

Geophysical

Magnetics - The magnetic anomaly over the investigated intrusive. is one of the world's most intense. As measured by both aerial and ground surveys it ranges over 35,000 gammas above regional values.

The observed anomaly 18 the resultant of two components: an Induced magnetiam and a remanent magnetism. The induced magnetism is drectly dependent on the magnetite content of the intrusive and its direction is that of the earth's field. The intensity and direction of the remanent magnetism is dependent on the consolldation and post-consolidation history of the intrusive. It 18 important to consider both the intensity and the direction of the remanent magnetism, for if its contribution to the total magnetism is negligible, the anomaly cannot be explained by the mognetite concentration thus far observed and richer grade ore must be present.

By field determination, the polarity of the remanent magnetism was found to be homogeneous with the north-seeking pole downard, and with no reversals. Laboratory measurements on samples from both the 1958 and 
1959 drilling indicate that the remanent magnetiom is four to five times as strong as the induced, and the dip of the remanent vector is nearly parallel to that of the Induced. There is a possibility, however, that some of the measured samples fram the 1958 drilling may have been re-magnetized by a hand-mognet used in logging magnetite content. In addition, J. D. Martinez of Humble's Research section found that elght samples from drill bole H-9 were axdally magnetized, apparently by the drilling. Elther of the se events would, of course, render the measurements of remanent mognetism unrellable. Even as tempered by these latter f1ndings, the average of the earlier measurements probably should be accepted as falily accurate in view of their relative consistency. Under the deplcted conditions, therefore, a mass containing about 15 percent mogetite could well be accepted as having caused tbe observed anomaly. The data cannot, however, categorically rule out the possibility of richer ore at depth, or laterally.

\section{Electromagnetics - Two Afmag unlts, designed for rapid reconnais-} sance coverage, were employed at the beginning of the project. However, the olgmal strength of the earth's mogetic fleld was too weak in the project area for accurate messurement. An attempt was then made to use the Afmas instruments to measure the direction of the artificial field generated in the Turam loop arrangement. Thls method was not successful due, in part, to the presence of the large magnetic intrusive which distorted the fleld in such a manner as to make detection of amaller conducting bodies 1mpossible. Approximately thirtysix miles of line vere surveyed with the Afmag units in the northern portion of the claim area before this method was abandoned. 
One Turam unit was inftially furnlshed by Hunting for the purpose of detalling any promising anomalies detected by the reconnaissance Afmag equipment. When the Afmas method proved unsuccessful, an additional Turam Instrument was acquired in order to expedite the electromsenetic coverage of the clatm area. The Turam method required rather close and accurately placed intervals of measurement along a grounded cable or rectangular loop arrangement. Therefore, more time was required than originally anticipated to complete tbe coverage of the project area by the Turam units.

Elghteen anomalies were detected by Turam on the claim block, none of which were graded higher than "weak" or "doubtrul" by the Hunting interpreters. It is significant that none of the anomalles were interpreted as belng caused by base sulfides.

The probable causes of the "weak" to "loubtful" anomalies were classified into four categories by the Hunting report (1959).

1). Anomalles due to the conductivity of the major magnet1c bodles.

2). Anomalies caused by electrolytic action along fault or shear zones.

3). Anomalies caused by conductivity of magetite bearing "black" sands, deposited off the maln magnet1te bodies.

4). Anomalies due to the effects of an increase in the thickness of the overburden.

Drill holes $\mathrm{H}-10$ thru H-16 were located wholly, or in part, on the Turam anomalies. Two grounded cable reconnalssance surveys were extended beyond the western and eastern margins of the claim block for a distance of 
three miles. Th1s was done in an effort to locate a minerallzed contact zone between the intrusive and the country rock. No anomalies were detected on these surveys.

Refraction selsmograph - As the drilling program developed, it became apparent that the boundary of the intrusive could not be definitely established by interpretation of the magnetic or electromagnetic results. A refraction selsmograph survey was therefore attempted in the hope that, if distinct velocity contrasts existed between the intrusive and the surrounding country rocks, this method could detect them, and a determination of the intrusive boundary could be made. Unfortunately, the small Ronka Instrument was designed for single layer, shallow refraction work and was not suitable for the multiple layer problems which were encountered in the project area. This approach was therefore abandoned.

\section{Drilling}

Eleven holes, ranging in depth from 500 to 2000 feet, were drilled during the 1959 program. The total footage was 9144.5 feet, 6335.5 feet of which were drilled below the fluvial-glacial overburden. Core recovery was good, averaging more than 75 percent. Depth to bedrock ranged from 90 to 460 feet. A map of the pre-glacial, bedrock surface wh1ch 18 presented in Plate IV-B shows that the magnetite pyroxente phase of the intrusive tends to form topographic "h1ghs". Elevations shown on the map are sub-datum (zero datum 18 the collar of drill bole H-2). Significant drill hole intercepts are shown on Plate IX (In pocket) and in Table I. 


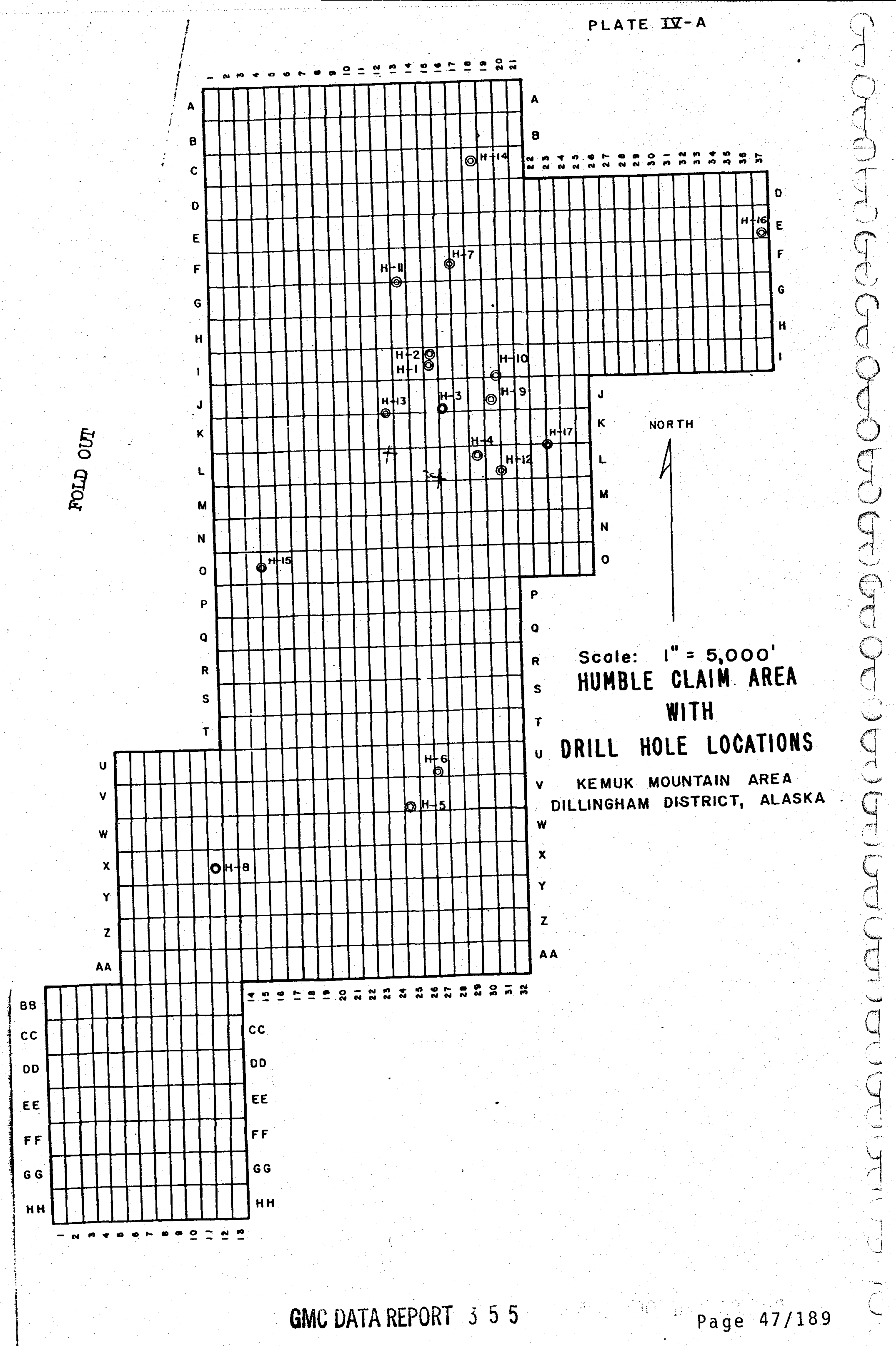




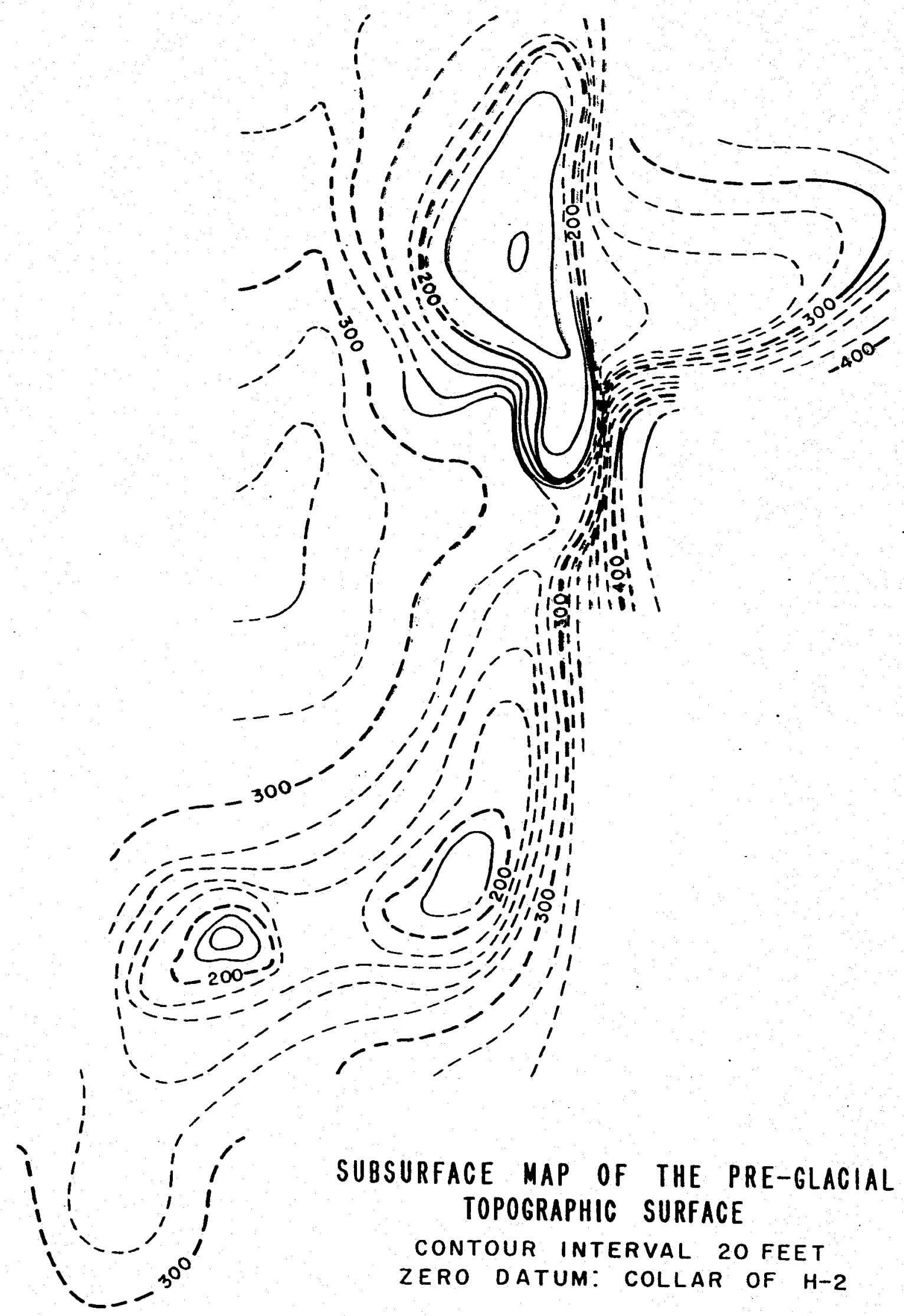



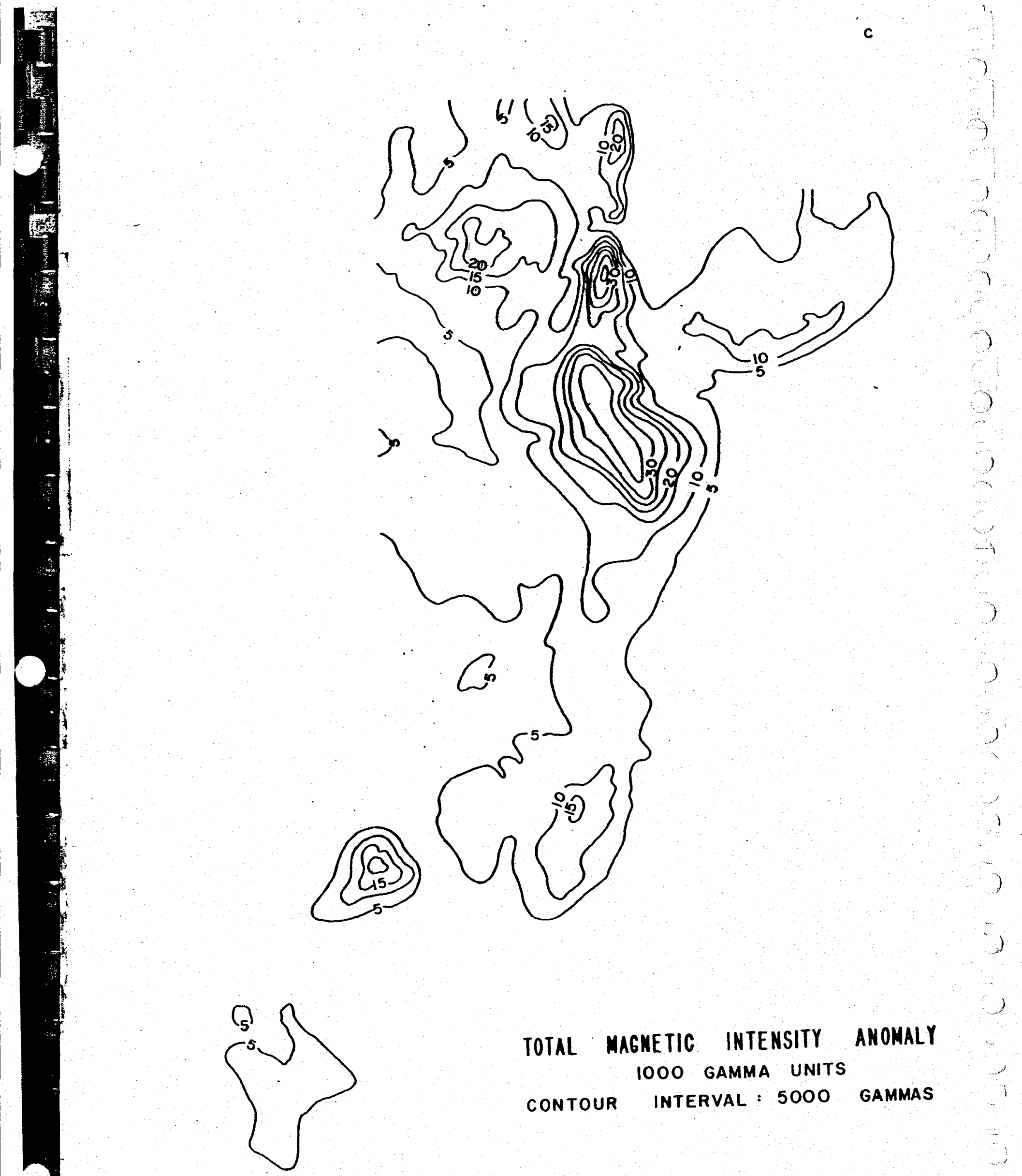

TOTAL MAGMETIC INTENSITY AMOMALY 1000 GAMMA UNITS CONTOUR INTERVAL: 5000 GAMMAS 


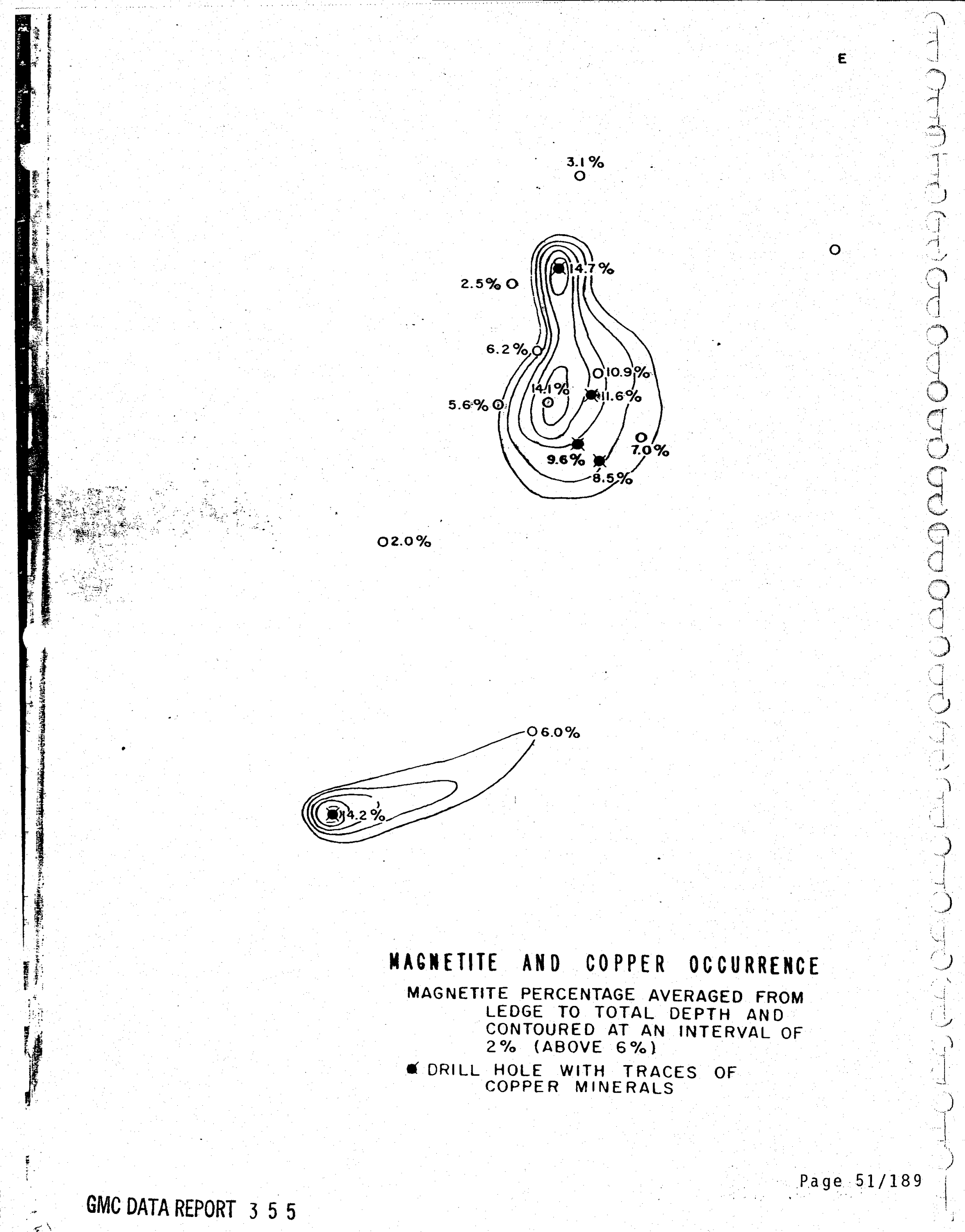


Table I.

\begin{tabular}{|c|c|c|c|c|c|c|}
\hline $\begin{array}{l}\text { DRILLING } \\
\text { INTERVAL } \\
\text { (FEET) } \\
\end{array}$ & $\begin{array}{c}\text { FEET } \\
\text { SAMPLED }\end{array}$ & $\begin{array}{l}\text { PERCENT } \\
\text { TOTAL } \\
\text { IRON } \\
\end{array}$ & $\begin{array}{l}\text { PERCINI } \\
\text { MAGNETIC } \\
\text { IRON }\end{array}$ & $\begin{array}{c}\text { PBRCENT OF TOTAL } \\
\text { IRON AS MAGNETIC } \\
\text { IRON }\end{array}$ & $\begin{array}{l}\text { PERCEANT } \\
\text { MAGNETTTE }\end{array}$ & LTTROLOGY OR CHARACTER OF INTERVAL \\
\hline $375-400$ & 25 & 6.89 & 2.28 & 33 & 3.2 & Pyroxente \\
\hline $375-487$ & 112 & 11.80 & 7.30 & 62 & 10.1 & Pyroxente and magnetite pyroxenite \\
\hline $390-1002$ & 612 & 15.23 & 10.16 & 67 & 14.1 & $\begin{array}{l}\text { Magnetite pyroxenite } \\
\text { (Total bole below overburden) }\end{array}$ \\
\hline $315-468$ & 153 & 13.37 & 6.95 & 52 & 9.6 & $\begin{array}{l}\text { Magnetite pyroxenite } \\
\text { (Anphibole - rich) }\end{array}$ \\
\hline $583-687$ & 104 & 10.22 & $(5.6)^{*}$ & $(55)$ & $(7.8)$ & Pyroxenite \& magnetite pyroxenite \\
\hline $151-2000$ & 1849 & 15.56 & $(10.6)$ & $(68)$ & $(14.7)$ & $\begin{array}{l}\text { Magnetite pyroxenlte } \\
\text { (Total hole below overburden) } \\
\end{array}$ \\
\hline $222-402$ & 180 & 16.36 & $(11.5)$ & $(70)$ & $(15.9)$ & Magnetite pyroxenite \\
\hline $402-500$ & 98 & 12.57 & $(6.3)$ & $(50)$ & $(8.7)$ & Gabbro \\
\hline $550-576.5$ & 26.5 & 19.37 & $(13.9)$ & $(72)$ & $(19.4)$ & Mopnetite pyroxenite \\
\hline $222-576.5$ & 354.5 & 15.76 & $(10.2)$ & $(65)$ & $(14.2)$ & Total hole below overburden \\
\hline $230-454.5$ & 224.5 & 11.64 & $(6.1)$ & $(52)$ & $(8.4)$ & Gabbro \\
\hline $454.5-1751$ & 1296.5 & 15.90 & $(9.9)$ & $(62)$ & $(13.7)$ & $\begin{array}{l}\text { Magnetite pyroxenite } \\
\text { (with amphibole-rich zones) }\end{array}$ \\
\hline $1373-1380$ & 7 & 29.65 & 25.43 & 86 & 35.4 & $\begin{array}{l}\text { Magnetite pyroxentte } \\
\text { (Magnet1 te-rich zone) }\end{array}$ \\
\hline $1751-1949$ & 198 & 13.45 & $(7.0)$ & $(52)$ & $(9.7)$ & Gabbro with some pyroxenite \\
\hline $1949-2000$ & 51 & 16.15 & 10.19 & 63 & 14.2 & Magnetite pyroxenite \\
\hline $230-2000$ & 1770 & 14.17 & $(8.4)$ & $(59)$ & $(11.6)$ & Total bole below overburden \\
\hline $201-532$ & 331 & 14.24 & $(7.9)$ & $(55)$ & $(10.9)$ & $\begin{array}{l}\text { Magnetite pyroxenite } \\
\text { (Amphlbole-rich) }\end{array}$ \\
\hline $159-500$ & 341 & 5.21 & $(1.8)$ & $(35)$ & $(2.5)$ & $\begin{array}{l}\text { Pyroxenite } \\
\text { (Total hole below overburden) }\end{array}$ \\
\hline $254-600$ & 346 & 12.20 & $(6.1)$ & $(50)$ & $(8.5)$ & $\begin{array}{l}\text { Gabbro } \\
\text { (Total hole below overburden) }\end{array}$ \\
\hline $350-668$ & 318 & 7.59 & $(4.0)$ & (53) & $(5.6)$ & $\begin{array}{l}\text { Pyroxenite and magnetite pyroxenite } \\
\text { (Total hole below overburden) }\end{array}$ \\
\hline $91-500$ & 409 & 6.32 & $(2.2)$ & (35) & $(3.1)$ & $\begin{array}{l}\text { Pyroxenite } \\
\text { (Total hole below overburden) }\end{array}$ \\
\hline $470-637$ & 167 & 5.38 & $(1.4)$ & (25) & $(2.0)$ & $\begin{array}{l}\text { Pyroxenite } \\
\text { (Total hole below overburden) }\end{array}$ \\
\hline $460-530$ & 70 & 11.99 & 5.01 & 42 & 7.0 & $\begin{array}{l}\text { Magnetite pyroxenite } \\
\text { (Amphibole rich) }\end{array}$ \\
\hline
\end{tabular}

I: Assayed and calculated iron content of algalficant drill-hole intercepts.

:ntages in parentheses are not directly assay determined but are calculated (see page IH $_{\text {). }}$.

TAREPORT 355 
Sample Analyois

Field examination - Detalled logs for each drill bole, tabulating drilling data, core recovery, sludge character, core lithology, and structural data, were prepared in the fleld (Appendix A). Field estimates of magnetite content based on the specific gravity of the core were found to be more reliable than those based on visual examination. The initial field estimates were visual, and thus were stated as percent by volume. Though the specific gravity method later replaced the visual, estimates continued to be stated as percent by volume for consistency. Assays are, of course, weight determined, and are stated as percent by weight. The mogetite percentages listed in the IIthologic logs are, therefore, less than the assay results, as percent magnetite by volume is equal to percent magnetite by weight times a factor of about 0.7 .

Assgys - The complete assiy results for the 1959 drilling are presented in Appendix B. In Table I, the Iron assay results from both the 1953 and 1959 drilling are grouped and averaged for significant drill hole intercepts. Percentages in parentheses are not directly assay determined, but are calculated from the assayed average total iron content of the intercept in the following manner: 1). All assays for magnetic Iron are classifled and grouped according to lithology or rock type. 2). An average ratio of magnetic iron content to total iron content 18 calculated for each lithology. 3). From these ratios, a ratio is calculated for each of the Intercepts chosen for Table I according to the 1 thologies represented in the intercepts. 4). Percent magnetic iron is calculated as this ratio times the average percent total iron in the intercept, and is divided by 0.72 to obtain the percent 
magnetite (magnetite is 72 percent iron). The table shows the early, pyroxenite phase of the intrusive, which occupies the bulk of the clatm block (see Plate IX), to average only 5 to 6 percent total Iron with 1 to 1.5 percent magnetic iron or 2 to 2.5 percent magnetite. As described later (page 18), the pyroxenite is cut by a sheet-like mass of magnetite pyroxenite. The sheet of magnetite pyroxente is the most magnitiferous phase of the 1gneous complex, and its western portion is richer in magnetite than its eastern. Short intercepts of relatively pure magnetite pyroxenite in the vestern portion of the sheet average 18 to 20 percent total 1ron, with 13.5 to 15 percent magnetic iron or 19 to 21 percent magnetite. In mineable thicknesses of 50 feet or more, dilution by later dikelets of gabbro and andesite lowers the averages to 15 to 17 percent total iron, with 10.5 to 12 percent magnetic Iron or 14.5 to 16.5 percent magnetite. The eastern portion of the magnetite pyroxenite sheet averages 13.5 to 15 percent total 1 ron, with 7.5 to 8.5 percent magnetic iron or 10.5 to 12 percent magnetite. The gabbro averages $\mathcal{L}$ to 13 percent total iron, with 5.5 percent to 6.5 percent magnetic 1ron or 7.5 to 9 percent magnetite. The richest drill hole intercept, at 1,373 to 1,330 feet in $8-9$, averages 35.4 percent magnetite. Even though diluted by late dikelets, the 26-foot zone at the bottom of $\mathrm{H}-8$ averages 19.4 percent magnetite.

Traces of copper minerals were noted in drill bole $\mathrm{H}-4$ during the 1958 drilling and in drill holes $\mathrm{H}-7, \mathrm{H}-8, \mathrm{H}-9$, and $\mathrm{H}-12$ during the 1959 drilling. All zones with vistble copper minerals were assayed for copper. The best sample from each of these holes assayed as follows: 
1). $\mathrm{H}-4,439$ to 464 feet - $0.05 \%$ copper

2). $\mathrm{H}-7,1744$ to 1759 feet - less than $0.01 \%$ copper

3). $\mathrm{H}-8,228$ to 235 feet $-0.04 \%$ copper

4). H-9, 1971 to 1975 feet - 0.17\% copper

5). $\mathrm{H}-12,254$ to 401 feet - less than $0.1 \%$ copper

All the copper assays are too low to be of economic interest. Samples from drill hole $H-9$ with visible sphalerite assayed only 0.01 to 0.025 percent zinc.

Concentration tests - Stipulating that a marketable concentrate of the ore should contain at least 65 percent iron and assuming that only 90 percent of the magnetite is recoverable in the concentrates, sampled portions of the magnetite pyroxente intrusive would require the following concentration ratios:

1). Average mineable thicknesses in the vestern part of the intrusive (samples from $H-3, H-7$, and $H-8$ ) would yleld an "ore" requiring 6.3 tons of crude to produce one ton of concentrates.

2). The 26 -foot zone at the bottom of $\mathrm{H}-8$ would require a 5 to 1 concentration ratio.

3). The seven-foot, magnetite-rich zone at 1373 to 1380 feet in H-9 would require a 2.8 to 1 ratio.

4). "Ore" from the eastern portion of the intrusive (samples from $H-4, H-10, H-17$, and part of $H-9)$ would require a 9 to 1 concentration ratio.

Representative concentrates from the 1958 arilling (Longyear Report March 1959) were found to contain acceptably low quantities of silica ( 2 to 3 percent) and phosphorus oxide ( 0.005 to 0.016 percent), but an objectionable emount of titania ( 2 to 3 percent). 


\section{Electric Logging}

An examination of the Widco electric logs obtained from the drill holes revealed the following data:

1). A good correlation existed between the resistivity curves and the magnetite percentages found in the intrusive. Similarly, a close correlation was found between the resistivity curves and the specific gravity of the cores as determined in the field. (See Plate V, Fig. 2).

2). In drill holes where shear zones were encountered, the resistivity curve correlated well with the lithologic 108 and the specific gravity curve in depicting these zones. (See Plate V, FIg. I).

\section{Geology and Petrogenesis}

The investigated intrusive is a composite of lithologic units ili in have apparently been derived from a siogle ultrabasic magma source. Pyroxenite (a coarse-grained igneous rock consisting primarily of the mineral pyroxene with minor magnetite, amphibole, biotite and apatite) is the first Intrusive phase and forms the bulk of the intrusive. It is succeeded by magnetite pyroxentte (coarse-grained, consisting primarily of pyroxene and magnetite with minor amphibole, biotite, apatite, and rarely some plagioclase feldspar), gabbro (coarse-grained, consisting primarlly of pyroxene and plagioclase feldspar with minor magnetite, ampibole and biotite), and andesite (fine-gralned, consisting primarily of plagioclase feldspar, pyroxene and amphibole with minor magnetite). Only the magnetite pyroxenite merits consideration as a possible source of Iron ore. Minor traces of copper minerals were noted in all of the rock types but the early pyroxenite. 
Figure 1: DRILL HOLE II

(Pyroxenite with little magnetite) Resistivity lows opposed by specific gravity lows are zones of shearing \& crushing.
Figure 2: DRILL HOLE 8

(Magnetite pyroxenfte with gabbro dikes) Resistivity Iows with specific gravity highs are magnetitẹ-enriched zones. Resistivity highs with specific gravity lows are dikes of gabbro or andesite.

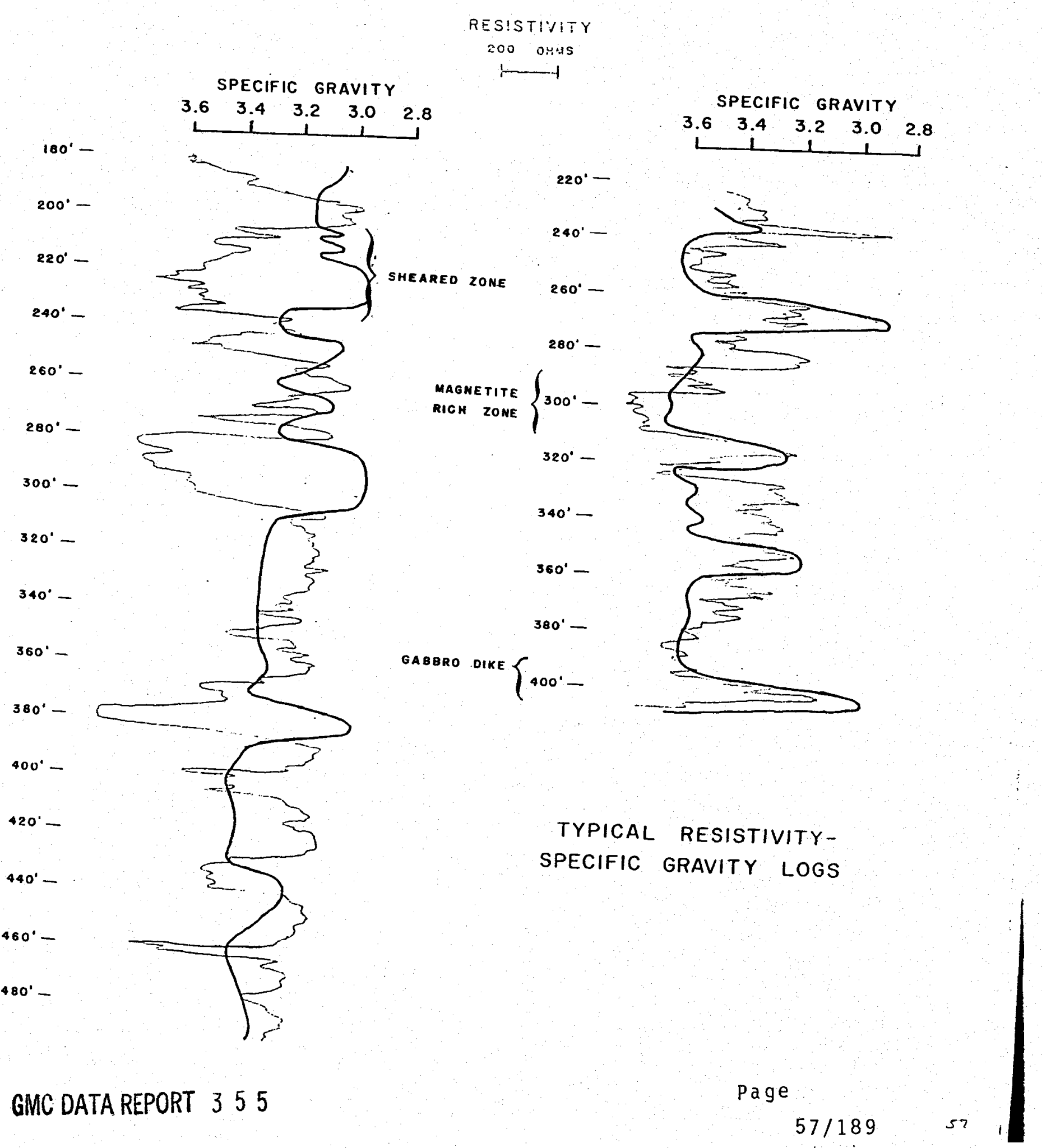


Feologic History

ihe intrusion of the igneous complex, probably in late Cretaceolis to early Fertiary, was at considerable depth into siliceous sediments wioh closely resemble the Cretaceous sediments bordering the Iushagak lowland to tire rest and to the northeast. The magnetite pyroxenite, which may refiect the habit of intrusion of the whole igneous complex, was probably injected ai a nearly horizontal, sheet-like mass. Post-intrusion regional tectonism uplifted, tilted and faulted the mass. It was stripped of its cover of sediments and bared to erosion by late Tertiary. Fluvial sorting of pyroxenite debris nay have formed a few sinuous magnitiferous sand deposits on and near the exposed intrusive. Thin patches of very fine-grained sediments encountered in $\mathrm{drill}$ holes $\mathrm{H}-4, \mathrm{H}-7$, and $\mathrm{H}-17$ bear some resemblance to the tuffs interbedded in the Quaternary-Tertiary volcanic series east of the Mushagak SIVer (Plate II), but may be of loess-type, deposited with the quaternary fuvial-glacial sediments which have innundated the area.

\section{Size and Structure of the Intrusive}

The pyroxentte pinase of the intrusive has an areel extent of at least 25 square miles, and occupies the major portion of the clajm block. Data are insufficient to delineate its northern, western, or southern iinits. The magnetite pyroxente is intrusive into the earlier pyxoxenite. It is a sheet-like mass which dips steeply to the east or southeast at an angle of at least $45^{\circ}$ and possibly more than $60^{\circ}$. The east dip was suggested by $D r$. Paterson in his interpretation of the magnetics (February, 1959), and is substantiated by the distribution of hydrous silicates or water-containing 
sillcates (amphibole, blotite, etc.) In the mass. The hydrous sillcates, whlch tend to form in the upper portion of an Intrusive, show a gradual increase in concentration toward the east. The top of the sheet mist, therefure, be its eastern margin, and its dip must be to the east (see Plate VI). Across the main magnet1c high, the magnetite pyroxenite sheet is at leitut 4,000 feet thick and extends to undetermined depths. It underlics an area of at least four square miles.

Gabloro Intrudes both the pyroxenite and the magnetite pyroxenite as steeply dipping dikes as thick as 500 feet. Dikes of andesite are of random attitude and are only a few inches to a few feet in thickness. Both the magnet1c and the electromagnetic data deplet a set of parallel faults trending northwest through the claim block. Where intersected by tile drill holes, the faults are steeply dipping (average $70^{\circ}-75^{\circ}$ ) with essentially horlzontal, rlght-lateral displacement (the north block has moved eastward relative to the south block).

Petrogenesis.

Crystallization of the magna - The first magma phase (normal pyroxenite) is characterized by a relatively low total iron content (av. 5 ti 5 percent) and by crystallization under reducing conditions which iniviolted precipltation of Iron oxides (megnetite). Its magmatic crystallization was almost entirely of two types of pyroxene minerals: an early pyroxene which contalned one to two percent excess iron and titanium in solid solution and a Later, diopsidic or calcium-rich pyroxene. An exsolution or unmixing of the excess iron and titanium from the early pyroxene formed sooty-black 
patches of an intergrowth of pyroxene and magnetite-ilmenite. The exsiution probably took place during the precipltation of the second, diopsidic pyroxene. This second pyroxene is found in all of the phaneritlc or coarsegrained rucks of the igneous complex, confirming their common origin. The second magma phase (magnetite pyroxenite) probably intruded before the earlier pyroxentte had completely solidified, in a manner similar to that suggested by Ruckmick and Noole (1959) for the Union Bay ultrabasic comolex near Ketchikan. Pre-Intrusion differentiation Increased the total. Iron content of the magnetite pyroxenite magma to 18 to 20 percent and produce: 1 iryitallization environment that was sufficiently oxidizing to tu precipitate an average of 20 percent magnetite (see page 15 ) in the lower portion 01 the intrusive sheet. The magnetite was apparently later than most of the pyroxene as 1 t occurs in the interstices between the pyroxene crystals. on the other hand, much of it was earlier than the bydrous silicates (amphibole, biotite, etc.) as its concentration decreases with the incrcasIng animant of hyarous silicates in the upper portion of the intrusive. A change in the differentiation trend of the magna from ironenrichment to sillca-enrichment can be traced through a sequence of rock typos transitional from magnetite pyroxenite to gabbro. The transitional sequence shuws that the magnetite pyroxentte and gabbro are genetically. related, and contact relationships show that the gabbro is the later of the two. The last intrusive phase, andesite, was relatively late, probably aiter removal of a large part of the cover of sedinents. Dikelets of andesite are ubiquitous and effectively lower the average magnetite content of mineable intervals of the magnetite pyroxenite.

\section{GMC DAIA REPORT 355}


Concentration of magnetite - Magnetite content Increases toward tise westers or lower portion of the magnetite pyroxenite intrusive (see page 25$)$. Though the total imn content is high in the castern portion, almos: 50 percent of it is tied up in silicate minerals and is nonrecuverable. Ais stated abcve, magnetite crystallized late, in the interstices of a network nesn of earlier crystals. Magnetite-rich zones such as at 1,375 feet In drill hole H-9 are probably lens-like and represent injections of the late, Sron-rich residue of the magma along shears in the semi-rigid crystal network. Gravity settling of this iron-rich residue through the crystal mesa nuy jartly explain the concentration of magnetite toward the base of the intrusive.

Several of the drill holes encountered possible magnitiferous sants directly overlying the intrusive. Estimates of the magnetite content of these sands are as higin as 70 percent, but they are based on drilling sluogres only and their validity is very questionable. These "black sands" may be sufficiently conductive to cause some of the electromagnetic anomalies, out they are considered as too deep and too thin to be of economic interest.

\section{Distribution of copper minerals - Copper minerals were found}

asisuciated only with the last three phases of the intrusion (magnetite pyroxenite, gabbro, and andesite). Chalcopyrite (sulfide of copper and iron)

is botis primary, deposited by medium to high temperature hydrothermal solutions, and secondary, deposited by circulating ground water. Native copper is secondary, deposited by cold water under reducing conditions. Unfortunately, there 1 s little tendency for the copper minerals to concentrate. They are finely disseminated in quantities that are far from economic.

GMC DATA REPORT 355 
Graphic Representation of the Intrusive

The authors' interpretation of the geology of the intrusive is presented in two cross-section views (Plates VI and VII) and one plan view (Plate IX). Since this is an interpretation, its validity shoula be judged in the light of the data on which it is based. It embodies the foliowing hypotheses, which are listed slong with their substantiating data:

\section{1). The intrusive is cut by a parallel set of faults which} Strike northwest, dip steeply to the south, and have nearly horizontal, rigit--lateral displacement. The fault locations, trends, and relative displacements are suggested by Dr. Paterson in his interpretation of the uagnetici:. The indicated dip of the faults and the direction of movement ar. ossea on the average attitude of shear planes and striations in core samples from the fault zones. The south dip is indicated by the shape of tise eiectromagnetic fault ansmalies.

2). The magnetite pyroxenite is intrusive into the earlier Miranite. This is indicated by the contact relationships. The pyroxenite is out by jffshoot dikes from the main magnetite pyroxenite mass.

j). The magnetite pyroxenite intrusive is a sheet-like mass Which dips steeply to the east or southeast. This is indicated by the distruation of hydrous silicates and magnetite in the intrustve, and by Dr. Paierson's interpretation of the magnetics.

4). The conflguration of the magnetic anomaly is a valid reflection of the lithology of the intrusive and may be used to locate approximately thie contact between the pyroxentte and the magnetste pyroxenite. This is 
indicated by the fleld and laboratory tests of the magnetic properties of the core samples. Though remanent magnetism contributes substantially to the observed total magnetic anomaly, its polarity and direction are fairiy homogeneous, and the configuration of the anomaly is directly dependent on the magnetite content of the intrusive and on the depth of the overburden.

5). The main gabbro dike encountered in $\mathrm{H}-10, \mathrm{H}-9$, and $\mathrm{H}-12$ (Plate VI) strikes slightly west of north and dips steeply to the east. The attitude of the dike was measured in portions of the core that were in and adjacent to fault zones. The core was oriented by aligning shear planes parailel to the strike of the fault as indicated by the magnetic and electromagnetic data.

6). The gabbro dike encountered in H-8 (Plate VII) strikes northwest and dips steeply to the west. Orientation was determined by the. technique described above.

7). The set of dikes encountered in H-13 (Plate VI) strike north and dip at a low angle to the west. The dip measured in the core is in the opposite direction to that of the dikes of magnetite pyroxenite which are assumed to dip back toward the main parental mass of magnetite pyroxenite.

8). Magnitiferous sands overlie the intrusive as stnuous, lenslike bodies which trend north-south (Plate IX). The sands were encountered in several of the drill boles. The extent and trend of the deposits is shown by the electromagnetic data. 


\section{Economic Considerations}

Economic Evaluation

Economic evaluation of the Humble prospect involves the following considerations :

1). As a basis for comparison, the combined cost of underground mining and beneficiation of Minnesota iron ore averaged $\$ 7.08$ per ton in 1957, and the cost of open-pit mining and ore beneficlation averaged $\$ 3.68$ per ton (Longyear Report, October 1959). As the Investigated intrusive lies beneath 90 to 460 feet of overburden, its mining probably would be by underground methods. Ore requiring a concentration ratio of 2 to 1 to produce a marketable concentrate containing 65 percent iron would cost $\$ 24.16$ per ton of concentrates at Minnesota's underground mining rates. Costs in Alaska, however, could be up to 50 percent higher than those in Minnesota. Although involving higher capital outlay, handling of large tonnages by intense mechanization could appreclably lower the mining and milling costs. Through a mechanization program in the Iron mines at Kiruna, Sweden, underground mining is economically replacing open-pit mining.

2). The cost of transporting concentrates from the mill site to the market would be on the order of $\$ 2.28$ per ton to San Francisco and $\$ 4.05$ per ton to Tokyo (based upon data from Humble Traffic Department).

3). The selling price of Bessemer-grade concentrates (low phosphorous content, 65 percent iron) is $\$ 14.64$ per ton at Lake Erle. A somewhat higher price might be expected for similar concentrates from buyers in the Paciflc Reglon. Concentrates from the Investigated prospect would command a price premium for their low phosphorous content, but would incur some price penalty for high titanium content. 
In the light of the above data, ore from the investigated prospect should contain at least 36 percent magnetic iron (require no more than two tons of crude to produce one ton of concentrates) to be mined profitably at this time. As stated earlier, mineable thicknesses of magnetite prroxente in the western portion of the intrusive average 10.5 to 12 percent magnetic iron (require a 6.3-to-1 concentration ratio), but the mogetite content of the intrusive appears to increase westward. The magnetite enrichment may not be sufficient to produce ore of 2-to-1 concentration grade, but it could well produce an ore zone of 3- or 4-to-1 concentration grade along the entire western margin of the intrusive sheet. A long-term view of the Iron ore economics of the Pacific Reglon suggests that such an ore might be mineable at a profit at some time in the future. (i.e. 20 years). The western Unfted States and Japan provide a large and steadily increasing demand for iron ore. To meet this demand, deposits are being developed in Chfle, Western Canada, and Southeastern Alaska (the Alaskan deposits are ultrabasic intrusives that are strikingly similar to the investigated Igneous complex, but they are well exposed and located near tidewater). The estimated total reserves in iron ore deposits which are tributary to the Pacific Region, however, are relatively low. This combination of dwindling reserves and increasing market demands, along with cost-reducing technological advances in minting and milling of iron ore could substantially improve the competitive position of the investigated prospect.

Claim Retention

The money expended in two seasons' work in the prospect area should be applled toward the retention of those claims staked over the ares 
of greatest interest. This action will protect the Company's investment If an outside $11 \mathrm{rm}$ shows an interest in further development of the area. There are two methods by which these claims can be retalned:

1). The fulfillment of the work assessment requirement of the Mining Law.

\section{2). Claim patenting.}

To fulf1ll the work assessment requirement, a minimum of $\$ 100$ mast be expended in labor or improvements per claim per year. The Mining Law allows the expenditure for labor or improvements on one claim to apply to the contiguous claims, 1.e. those having a common boundary (not a conmon corner), as long as the expenditure 18 equal to $\$ 100$ for each of the claims 1nvolved. It mist be shown that such expenditure will benefit all claims Involved and that they will be developed as a group. Recent changes in the Mining Laws permit geophysical work to be considered as labor and improvements to fulfill the annual work assessment requirement. The alternative, or claim patent procedure, requires that $\$ 500$ in labor and improvements be expended per claim in order to obtain a patent. According to the strictest interpretation of patent regulations, only those claims which have been drilled and thelr contiguous claims can be patented (see plate vIII). If geophysical work 18 considered as valid claim development, its cost may be included in the expenditure necessary for patenting, and any or all of Humble's 815 claims could be patented. The authors, however, would recommend patenting of only 133 claims in the area of greatest interest (Plate VIII). Based on our Interpretation of the Mining law (Charles C. Keeble, personal comminication), the first assessment year for fumble's claims 


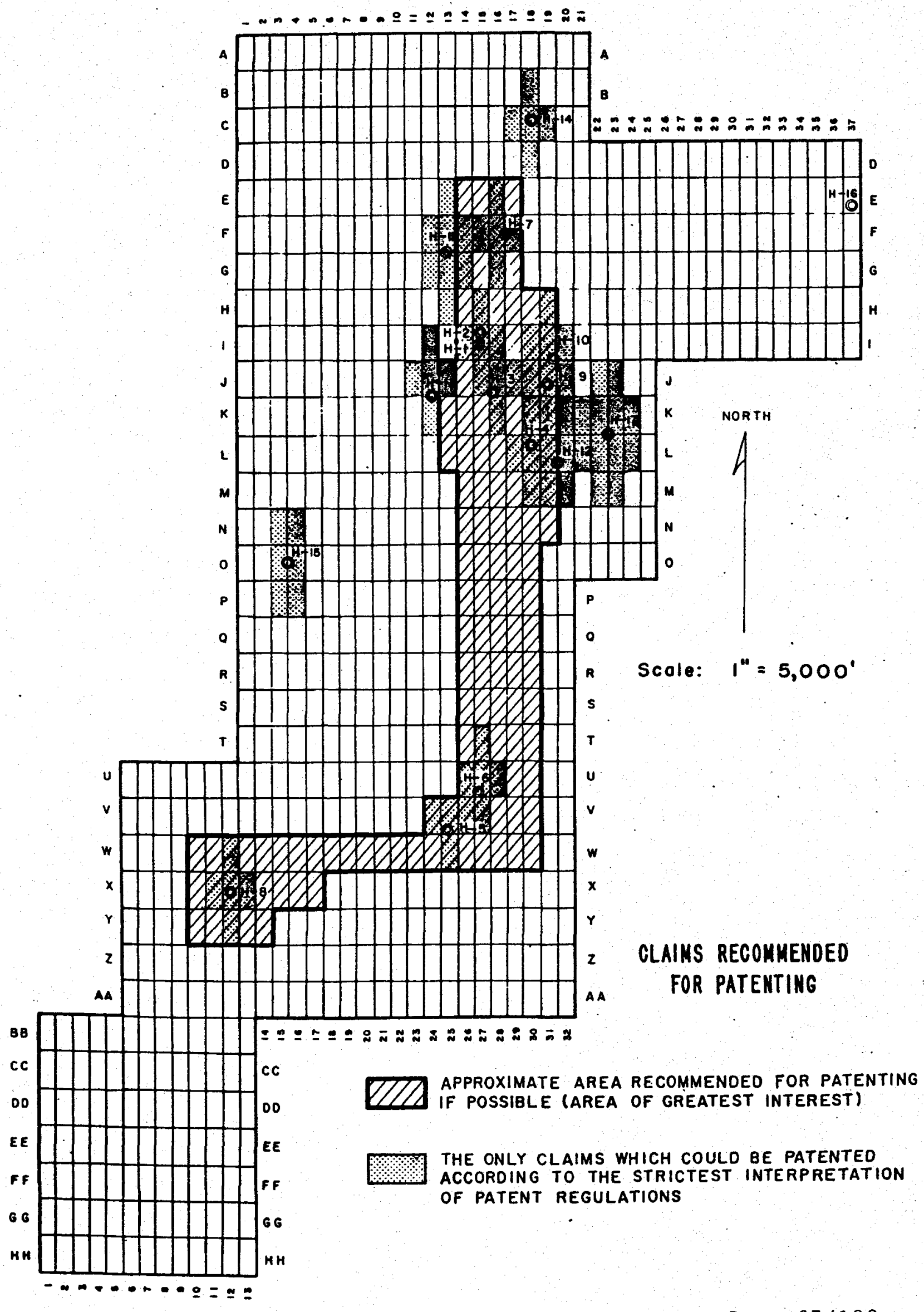


began on September 1, 1959, and the Company has unt1l August 31, 1960, to exercise either the work assessment or claim patent option.

\section{SUMMARY}

The magnetic anomaly which initiated interest in this project is caused by an 1gneous mass of magnetite pyroxentte which lies burled beneath 90 to 460 feet of overburden. Though the magnetite pyraxentte is only one phase of a larger leneous complex, it 1s the only phase that possesses any economic possibilities. The areal extent of the igneous complex is at least 30 square miles, about four square miles of which is magnetite pyroxentte. In two summers of fleld work, the Intrusive has been surveyed by magnetic and electromafnetic methods and sampled by 14 of a total of 17 core dr111 holes. No sampled portion contained a sufficient concentration of magnetite to be mined economically at this time. Although minor intercepts of the magnetite pyroxenite contain as much as 35 percent magnetite, or 25 percent magnetic 1ron, mineable thlcknesses average only 14.5 percent to 16.5 percent magnetite, or 10.5 to 12 percent magnetic Iron. Such an ore would require 6.3 tons of crude to produce one ton of marketable concentrates. Ore of a twoto-one concentration grade is suggested as the minimum that could be profitably mined at this time at a location such as that of the investigated prospect.

Though the magnetite pyroxenite was probably intruded as a relatively horizontal, sheet-like mass, it has been uplifted and tilted by regional tectonism. The mass now dips steeply to the east or southeast, and what had been 1ts bottom is now 1ts restern margin. There 18 apparently some tendency for magnetite enrichment in the lower or western portion of 
the intrusive. The bottom has not been reached by the drilling, and a possibility of appreclable magnetite enrichment near the bottom 1s untested. The enrlchment may not be sufficlent to produce ore of the recomended twoto-one concentration grade, but it could well produce an ore zone of three or four-to-one concentration grade along the entire western margin of the intrusive sheet. Though not of economic grade at this time, a long-term view of the iron ore economics of the Paciflc Reglon suggests that such an ore might be mineable at a profit at some time in the future. There is little evidence for economic occurrences of minerals other than magnetite.

\section{RECOMMENDATIONS}

It is recomended that muble do no further exploration work in the prospect area. The untested possibllity of an economic concentration of magnetite near the bottam of the magnetite pyroxenite intrusive may encourage a mining $1 \mathrm{Irm}$ to obtain the property for further exploration. It is recommended that any possible future drilling program include at least one 1,000-foot to 2,000-foot arill hole about 500 feet west of H-3 and another deep test about 500 feet west of H-8. Unless the property 18 turned to another company by August 1960, the money that has been spent on the project should be applied toward the retention of those claims located over the areas of greatest interest. The cladms may be held until August 31 , 1961, by applying the woney to furflliment of the work assesament requtrement or they may be held indefinitely through patenting. 
E. J. Longyear Company, March 1959, The Exploration of the Kemuk Mountain Magnet1c H1ghs, Dillingham District, Southwest Alaska: Report to Humble 011 and Refining Company.

E. J. Longyear Company, October 1959, The Exploration of the Kemuk Mountain Magnetic H1ghs, Dillingham District, Southwest Alaska: Report to Bumble 011 and Refining Company.

Ceophoto Services, May 1957, Photogeologic Evaluation of the West Briatol Bay Area, Alaska: Memorandum Report No. 17 to Humble 011 and Refining Company.

Hunting Technical and Exploration Services Limited, September 1959, Geophysical Ground Investigatlons, Kemuk Mountain Claim Block, Alaska: Report to Humble 011 and Refining Company.

Nert1e, J. B., Jr:, 1938, The Nushagak D1strict, Alaska: U.S. Geologlcal Survey Bulletin 903, $\overline{96}$ pp.

Ruckmick, Jobn C. and Noble, James A., 1959, Origin of the Ultramafic Complex at Union Bay, Southeastern Alaska:- Geological Society of America Bulletin, v. 70, p.981-1018.

Walston, V. A., February 1959, Core Dr1ll Project, Kemuk Mounta1n Area, Alaska: Humble 011 and Refining Company, Exploration and Production Departments, Civ1l Englneering Section Report. 


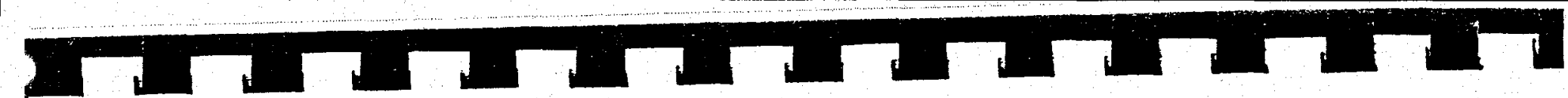

$$
\text { A P P E N D I X A }
$$

IITHOLOGIC LOGS FOR DRIIL HOLES H-7 THRU H-I7

GMC DATA REPORT 355 
Started: June 8, 1959

Completed: June 30, 1959

Mlevation (collar reference $\mathrm{H}-2$ ) $=-11 / 2$

Located in Claim 16F, 724 feet south of northeest cormer and thence 5 feet west.

From To Distance Core \% Rec. 0 Magn.

Character of Material

(Zero collar taken on top of platform 2 feet above ground. Used 4-1/4" rock bit to $120^{\prime}$, thence $3-3 / 4^{\prime \prime}$ bit to 151'.)

Wind-blown sand and silt (no sample)

Sand mostly 1/16" size or less, minor magnetite. Sand mostly 1/16" size or less, minor magnetite. Sand mostly 1/16" size or less, minor magnetite. Sand mostly 1/16" size or less, minor magnetite. Sand mostly 1/16" size or less, minor magnetite. Sand mostly 1/16" size or less, minor magnetlte. Coarse gravel, but mostly fine sand

Sand, fine, gray, few pebbles, mirror magnetite. Gravelly sand, minor magetite

Gravelly sand, minor magnetite

Send, fine, minor magnetite

Sand, fine, minor magnetite

Sand, fine to silt, gray; minor magnetite

138-151 Probably pyroxenite. Rock hard. high magnetite content in sludges, over $50 \%$ in panned cuttings (?) (Set $\mathrm{NX}$ casing $151^{\prime}$ and began corting $\mathrm{NX}$ size.)

$151 \quad 156$

5

$3.5 \quad 70 \quad 10-15$

151-156 Pyroxenite. Fine grained, dark green, broken. Contains 10-15\% magnetite by vol. (Set BX casing to $156^{\prime}$ will start wlre Ine barrel).

$156 \quad 158$

2

$2 \quad 100$

$11-23$

156-157 Pyraxentte, coarse; some green amphibole; I" sand at $157^{\prime}$ ' $20^{\circ}$ to core of gray green andesite with small cavities and some epldote crystals to $\frac{1 "}{4}$ 
DRILI HOLE H-7 Cont'd

\begin{tabular}{llllll} 
Fram & To & Distance & Core & $\begin{array}{c}\text { \% Core } \\
\text { Rec. }\end{array}$ & \& Magn. \\
\cline { 5 - 6 } & & & & & \\
& & & & & \\
158 & 160 & 2.0 & 2.0 & 100 & $10-15$ \\
160 & 160.5 & 0.5 & 0.5 & 100 & $10-15$ \\
160.5 & 161.5 & 1 & 0.75 & 75 & $10-15$ \\
161.5 & 167 & 5.5 & 5.5 & 100 & $10-15$ \\
167 & 169 & 2.0 & 2.0 & 100 & $10-15$ \\
169 & 181.5 & 12.5 & 10.5 & 85 & $10-15$ \\
181.5 & 184 & 2.5 & 2.5 & 100 & $10-15$ \\
184 & 194 & 10.0 & 10.0 & 100 & $10-15$ \\
194 & 200.5 & 6.5 & 6.5 & 100 & $10-15$
\end{tabular}

$\begin{array}{llllll}194 & 200.5 & 6.5 & 6.5 & 100 & 10-15 \\ 200.5 & 205.8 & 5.3 & 5.3 & 100 & 10-15 \\ 205.8 & 210.5 & 4.7 & 4.5 & 95 & 10-15 \\ 210.5 & 215 & 4.5 & 4.5 & 100 & 10-15 \\ 215 & 220 & 5.0 & 5.0 & 100 & 10-15 \\ 220 & 225.5 & 5.5 & 5.3 & 95 & 10-15 \\ 225.5 & 235.5 & 10.0 & 10.0 & 100 & 10\end{array}$

long; magnet1te av. 11-13 percent by vol.; some apat1te in white prisms and streaks.

157-180 Pyroxenite, gray-green, fine, with bands to 9" thick; of coarse pyroxentte; several inches of gray andesite (\&) $167^{\prime}$ with some epidote, cutting core \& $0^{\circ}$ $20^{\circ}$; at $171^{\prime}$ and $172^{\prime}$ are two white bands, each $1 / 2^{\prime \prime}$ thlak, of felsic minerals with minor chalcopyrite and pyrite, cutting core (s) $80^{\circ}$. 180-181.5 Andesite banded, cutting core (s) $0^{\circ}-20^{\circ}$; minor megnetite.

181.5-192 Pyroxentte, coarse; princlpally diopside and magetette (10 - 15\% by vol.); some bronze mica and some feldspar (late) in small prisms and seams.

192-235 Pyroxente, fine-medium, with bands of coarse up to two feet thlck, cutting core @ $0^{\circ}-300$; a few small apatite prisms and seams; few thin calcite velnlets largely along joints and fractures ( $90^{\circ}-45^{\circ}$ to core), locally with chlorite flakes and minor pyrite; at 226 ' $1 / 2$ " steep, irregular band of fels1cs and dark green homblende; principal minerals: diopside and magnetite (10 - 15\%) in 1rregular masses $1 / 16^{\prime \prime}$, or less, to $I^{\prime \prime}$, or more, in the coarser bands of pyroxentte.

$\begin{array}{llllrl}235.5 & 238.5 & 3.0 & 3.0 & 100 & 10 \\ 238.5 & 240 & 1.5 & 1.5 & 100 & 10 \\ 240 & 240.5 & 0.5 & 0.4 & 90 & 10 \\ 240.5 & 241 & 0.5 & 0.5 & 100 & 10 \\ 241 & 242.5 & 1.5 & 1.3 & 87 & 10 \\ 242.5 & 243 & 0.5 & 0.4 & 90 & 10 \\ 243 & 246.5 & 3.5 & 2.1 & 60 & 10 \\ 246.5 & 248 & 1.5 & 0.5 & 33 & 10 \\ 248 & 249 & 1.0 & 0.9 & 90 & 10 \\ 249 & 249.5 & 0.5 & 0.45 & 90 & 10 \\ 249.5 & 250 & 0.5 & 0.5 & 100 & 10\end{array}$

235-255 As above, but generally broken due to greater number of calcite-chlorite-talc-coated joints and fractures; 10 - $15 \%$ magaetite in 1rreg. grains \& masses to I" or less. 
DRIIL HOLE H-7 Cont'd

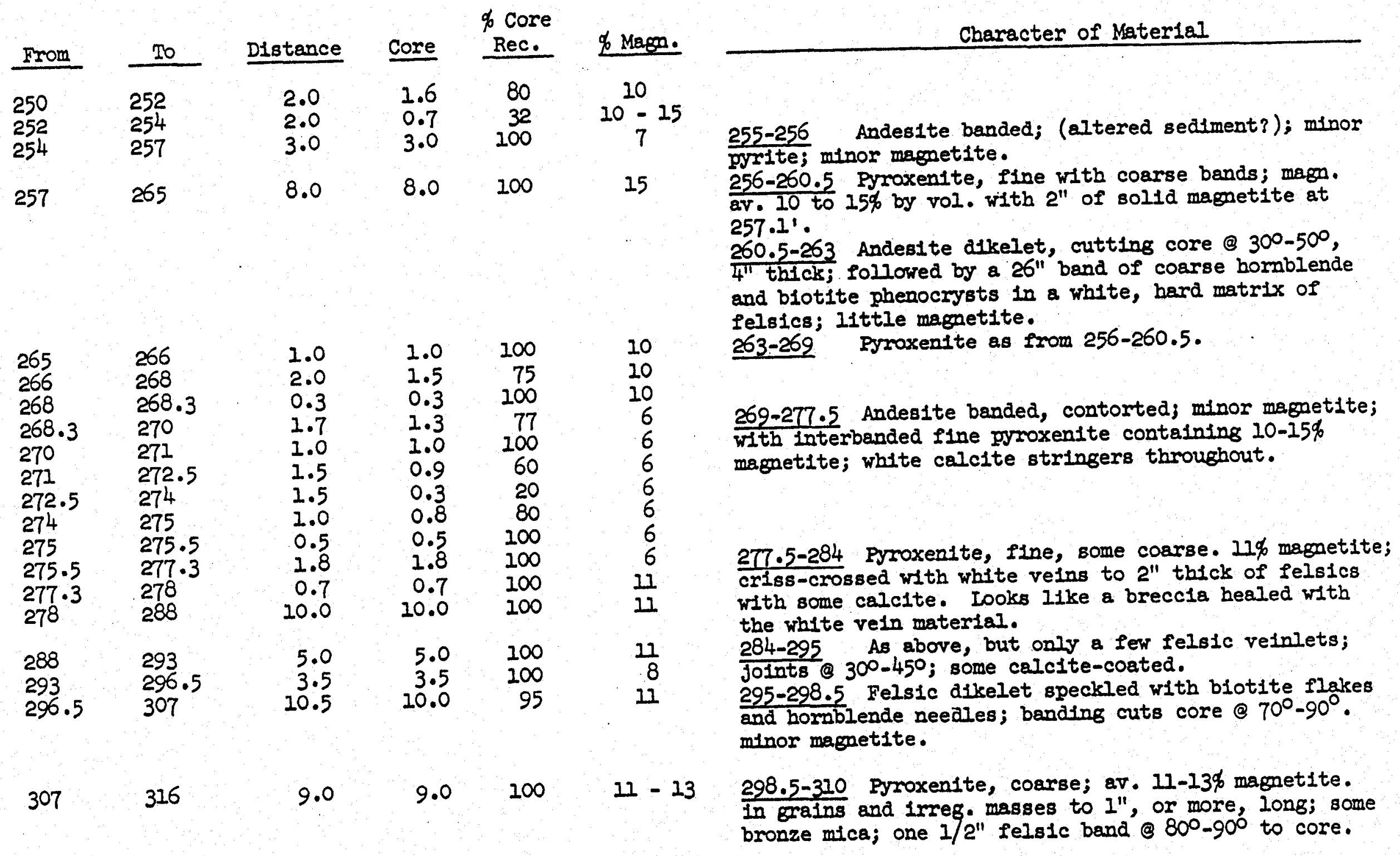


DRITL HOLE H-7 Cont'd

\begin{tabular}{|c|c|c|c|c|c|}
\hline From & To & D1stance & Core & $\begin{array}{l}\text { \% Core } \\
\text { Rec. }\end{array}$ & o Mogen \\
\hline $\begin{array}{l}316 \\
326 \\
336 \\
340.5 \\
350.5 \\
352 \\
356 \\
358\end{array}$ & $\begin{array}{l}326 \\
336 \\
340.5 \\
350.5 \\
352 \\
356 \\
358 \\
364\end{array}$ & $\begin{array}{r}10.0 \\
10.0 \\
4.5 \\
10.0 \\
1.5 \\
4.0 \\
2.0 \\
8.0\end{array}$ & $\begin{array}{r}10.0 \\
10.0 \\
4.5 \\
9.0 \\
1.5 \\
4.0 \\
1.2 \\
6.0\end{array}$ & $\begin{array}{r}100 \\
100 \\
100 \\
90 \\
100 \\
100 \\
60 \\
75\end{array}$ & $\begin{array}{l}12 \\
10 \\
11 \\
11 \\
11 \\
11 \\
11 \\
11\end{array}$ \\
\hline $\begin{array}{l}364 \\
368 \\
370\end{array}$ & $\begin{array}{l}368 \\
370 \\
375\end{array}$ & $\begin{array}{l}2.0 \\
2.0 \\
5.0\end{array}$ & $\begin{array}{l}2.0 \\
1.4 \\
4.5\end{array}$ & $\begin{array}{r}100 \\
70 \\
90\end{array}$ & $10-10$ \\
\hline $\begin{array}{l}375 \\
380 \\
381 \\
387 \\
389 \\
392 \\
395 \cdot 5 \\
399 \cdot 5 \\
403 \cdot 5 \\
405 \cdot 5 \\
406 \cdot 5 \\
410.0 \\
412 \\
416 \\
421.5 \\
423 \\
424 \\
425\end{array}$ & $\begin{array}{l}380 \\
381 \\
387 \\
389 \\
392 \\
395 \cdot 5 \\
399 \cdot 5 \\
403 \cdot 5 \\
405 \cdot 5 \\
406 \cdot 5 \\
410 \cdot 0 \\
412.0 \\
416 \\
421.5 \\
423 \\
424 \\
425 \\
435\end{array}$ & $\begin{array}{l}5.0 \\
1.0 \\
6.0 \\
2.0 \\
3.0 \\
3.5 \\
4.0 \\
4.0 \\
2.0 \\
1.0 \\
3.5 \\
2.0 \\
4.0 \\
5.5 \\
1.5 \\
1.0 \\
1.0 \\
10.0\end{array}$ & $\begin{array}{l}5.0 \\
1.0 \\
5.0 \\
1.0 \\
2.0 \\
2.1 \\
2.3 \\
0.9 \\
2.0 \\
1.0 \\
3.5 \\
2.0 \\
4.0 \\
5.5 \\
1.5 \\
1.0 \\
1.0 \\
10.0\end{array}$ & $\begin{array}{r}100 \\
100 \\
83 \\
50 \\
67 \\
60 \\
58 \\
23 \\
100 \\
100 \\
100 \\
100 \\
100 \\
100 \\
100 \\
100 \\
100 . \\
100\end{array}$ & $\begin{array}{c}10 \\
10 \\
10 \\
10 \\
10 \\
10-15 \\
10=15 \\
12 \\
12 \\
12 \\
12 \\
12 \\
12 \\
12 \\
12 \\
12 \\
6 \\
9\end{array}$ \\
\hline
\end{tabular}

Character of Material.

310-318 Pyroxenite, fine-medium, banding \& $30^{\circ}$ to core; av. $12 \%$ magnetite.

318-363 Pyroxenite, coarse, pegmatitic; diopside, 11\% mametite, some bronze mlca; 8" with $50 \%$ magn. at 331'; 1/2" streak of fine pyrite (a) 349' dipping 45\%; few thin calcite veins; felsics, locally with hormblende in Irreg. patches from 320-328 and in $I$ " bands dipping $45^{\circ}$ at $328^{\prime}$ and $342^{\prime}$.

363-366 Felsic band w1th mica \& nornblende, fine, dense; minor pyrite; rude banding \& 45 -900 to core. 366-370 Pyroxenite, coarse; 10-12\% magnetite; 4"band of andesite dipping $45^{\circ}$.

370-374 Felsic band, dense, minor magnetite \& pyrite, dipping $45^{\circ}$.

374-393 Pyroxenite, coarse, broken $10 \%$ metite

393-400 Pyroxentte, sugary, friable, brecclated; 10-15\% magnet1te; fault zone; $1 / 2^{\prime \prime}$ band at $396^{\circ}$ of graphitic material, slickensided, shears @ $30^{\circ}$ to core. 400-424.7 Pyraxenite, Iine-medium, . 12\% magnetite; $30^{\circ}-500$ joints coated with talc-chlorite and some calcite; ting apatite crystals at $423^{\prime}$.

424.7-425.3 Andesite banded (45 ); minor magnetite. 425.3-430 Pyroxenite as between 400-424. $430-433$ $433-435$ Andesite, flne, dark gray-green, dense. Dike, medium-grained, green gabbro; cuts core 
DRIIL HOLE E-7 Cont'd

\begin{tabular}{|c|c|c|c|c|c|c|}
\hline From & To & Distance & Core & $\begin{array}{l}6 \text { Core } \\
\text { Rec. }\end{array}$ & of Magn. & Character of Mater1al \\
\hline 435 & 437 & 2.0 & 2.0 & 100 & 11 & 435-437.5 Pyroxenite as between $400-424^{\prime}$. \\
\hline 437 & 440.5 & $3 \cdot 5$ & 3.0 & 85 & 8 & $\begin{array}{l}437.5-439 \text { Inclualon of sediment (?) hIghly altered to } \\
\text { coarse epldote crystals; some Iimey (?) ground mass, and } \\
\text { also some areas to } 1 / 4 " \text { of dark, soft serpentine; talc } \\
\text { along jolnts and shears. }\end{array}$ \\
\hline 440.5 & 449.0 & 8.5 & 8.5 & 100 & $10-15$ & $\begin{array}{l}\text { 439-452.5 Pyroxenite, medum-grained to fine; diopside } \\
\text { minor apatite, few small books mica, 10-15\% magnetite; } \\
\text { 1-foot band of coarse magnetite-free pyroxenite with } \\
\text { irregular grains and relns of felsics @ } 500 \text { to core at } \\
447 \text {; trace pyrite. }\end{array}$ \\
\hline $\begin{array}{l}449 \\
459 \\
463 \\
468 \\
474\end{array}$ & $\begin{array}{l}459 \\
463 \\
468 \\
474 \\
484\end{array}$ & $\begin{array}{r}10.0 \\
4.0 \\
5.0 \\
6.0 \\
10.0\end{array}$ & $\begin{array}{r}10.0 \\
4.0 \\
5.0 \\
6.0 \\
10.0\end{array}$ & $\begin{array}{l}100 \\
100 \\
100 \\
100 \\
100\end{array}$ & $\begin{array}{l}10-15 \\
\frac{12}{12} \\
12 \\
12\end{array}$ & 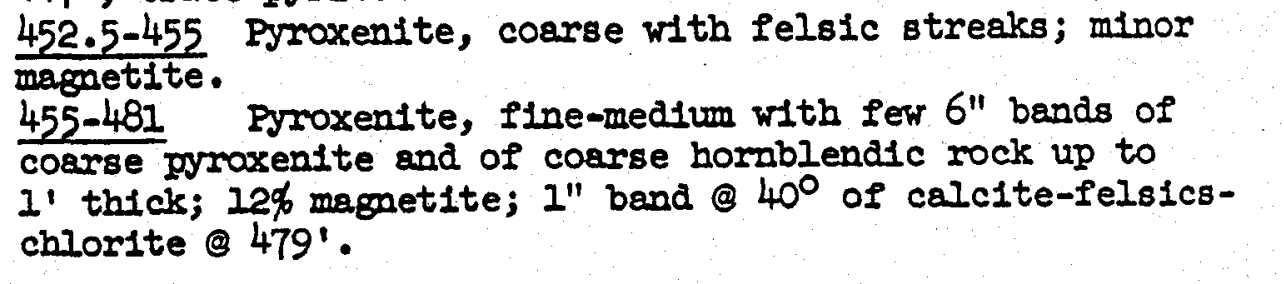 \\
\hline 484 & 494 & 10.0 & 10.0 & 100 & 10 & $\begin{array}{l}\text { 481-492 Pyroxentte, coarse-grained, darker green, horn- } \\
\text { blendic; 6" band of laminated andesite @ 483' @ 90 to core. }\end{array}$ \\
\hline $\begin{array}{l}494 \\
500 \\
501 \\
510 \\
513 \\
522 \\
526 \\
528 \\
538 \\
540.7 \\
548.7\end{array}$ & $\begin{array}{l}500 \\
501 \\
510 \\
513 \\
522 \\
526 \\
528 \\
538 \\
540.7 \\
548.7 \\
551.5\end{array}$ & $\begin{array}{r}6.0 \\
1.0 \\
9.0 \\
3.0 \\
9.0 \\
4.0 \\
2.0 \\
10.0 \\
2.7 \\
8.0 \\
2.8\end{array}$ & $\begin{array}{r}5.5 \\
0.8 \\
9.0 \\
3.0 \\
9.0 \\
4.0 \\
2.0 \\
10.0 \\
2.7 \\
8.0 \\
2.8\end{array}$ & $\begin{array}{l}90 \\
80 \\
100 \\
100 \\
100 \\
100 \\
100 \\
100 \\
100 \\
100 \\
100\end{array}$ & $\begin{array}{c}10-15 \\
10-15 \\
10-15 \\
10-15 \\
10=15 \\
15 \\
15 \\
10-15 \\
10-15 \\
10=15 \\
13\end{array}$ & $\begin{array}{l}492-551.5 \text { Pyrox. fine, gray, massive 10-15\% magnetite; } \\
4^{\prime \prime} \text { to } 8^{\prime \prime} \text { bands } 945^{\circ}-80^{\circ} \text { to core of banded andesite @ } 497^{\prime} \\
536^{\prime}, 540,544,547 \text {; few coarse bands to } 2^{\prime} \text { thick; few } \\
\text { calcite veinlets; few thin streaks of hormblende (9 } 45^{\circ} \text { dip; } \\
\text { in rare sections such as the } 6^{\prime \prime} \text { section @ } 526 \text {; magnetite } \\
\text { increases to about } 17 \% \text {. }\end{array}$ \\
\hline 551.5 & 554 & 2.5 & 2.5 & 100 & $10-15$ & $\frac{551.5-554}{\text { patches. }}$ Pyroxentte, coarse, hornblendic with felsic \\
\hline
\end{tabular}


DRIIC HOLE H-7 Cont'd

\begin{tabular}{|c|c|c|c|c|c|c|}
\hline From & To & Distance & Core & Rec. & o Magn. & Character of Material \\
\hline $\begin{array}{l}554 \\
556.5 \\
559 \\
563\end{array}$ & $\begin{array}{l}556.5 \\
559 \\
563 \\
565\end{array}$ & $\begin{array}{l}1.5 \\
2.5 \\
4.0 \\
2.0\end{array}$ & $\begin{array}{l}1.5 \\
2.5 \\
4.0 \\
2.0\end{array}$ & $\begin{array}{l}100 \\
100 \\
100 \\
100\end{array}$ & $\begin{array}{c}10-15 \\
10-15 \\
10-15 \\
6\end{array}$ & $\begin{array}{l}\text { 554-562 Pyroxenite, Ilne-medium 10-12\% magnetite. } \\
\frac{562-564}{\text { pyrite; A Adesite, } 45^{\circ}-60^{\circ} \text { to core; one thin calcite veln. }}\end{array}$ \\
\hline $\begin{array}{l}565 \\
568 \\
571.5\end{array}$ & $\begin{array}{l}568 \\
571.5 \\
581.5\end{array}$ & $\begin{array}{r}3.0 \\
3.5 \\
10.0\end{array}$ & $\begin{array}{r}3.0 \\
3.5 \\
10.0\end{array}$ & $\begin{array}{l}100 \\
100 \\
100\end{array}$ & $\frac{12}{12}$ & $\begin{array}{l}\text { 564-574 Pyroxentte, fine-medium; with } 12 \% \text { magnetite, and } \\
\text { some bronze mica; few coarger bands. } \\
574-583 \text { cabbro dike, @ } 15^{\circ}-30^{\circ} \text { to core; light gray-green, } \\
\text { flne-medium grained; made up of feldspar, bornblende \& } \\
\text { scme biotite. }\end{array}$ \\
\hline 581.5 & 586.5 & 5.0 & 5.0 & 100 & 10 & $\begin{array}{l}\text { 583-584 Interlayered, pyroxenite and andesite. } \\
584-586.5 \text { Pyroxentte, coarse, } 10 \% \text { magnetite. }\end{array}$ \\
\hline $\begin{array}{l}586.5 \\
589 \\
592 \\
595\end{array}$ & $\begin{array}{l}589 \\
592 \\
595 \\
600\end{array}$ & $\begin{array}{l}2.5 \\
3.0 \\
3.0 \\
5.0\end{array}$ & $\begin{array}{l}2.5 \\
3.0 \\
3.0 \\
5.0\end{array}$ & $\begin{array}{l}100 \\
100 \\
100 \\
100\end{array}$ & $\begin{array}{r}8 \\
12 \\
12 \\
7\end{array}$ & $\begin{array}{l}\frac{586.5-587}{587-596} \text { Andesite, banded @ } 200 \text { to core, chloritic. } \\
\text { Pyroxenite, fine-medium 12\% magnet1te. } \\
596-599 \text { Andesite as between } 586-587 \text {, flnely banded, } \\
\text { contorted, @ } 00-45^{\circ} \text { to core; trace pyrite. } \\
599-600 \text { Pyrox., coarse, 10\% mage.; some irregular areas } \\
\text { of felsics; some large hormblende crystals. }\end{array}$ \\
\hline 600 & 610 & 10.0 & 10.0 & 100 & 8 & 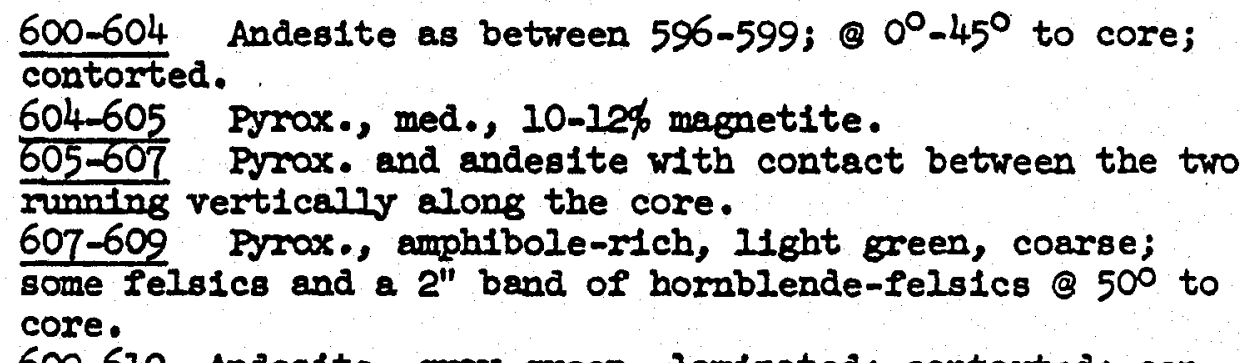 \\
\hline 610 & 616 & 6.0 & 6.0 & 100 & 10 & $\begin{array}{l}\text { 609-612 Andesite, gray-green, laminated; contorted; con- } \\
\text { tact w1th pyrax. (3 600-900 to core. } \\
612-616 \text { Pyroxentte, med-fine, 12\% magnet1te. }\end{array}$ \\
\hline 616 & 620 & 4.0 & 4.0 & 100 & 8 & $\begin{array}{l}\text { 616-618 Andesite, gray-green, banded (a 400; 1rreg. con- } \\
\text { tact w1th pyroxenfte; felsic bands. }\end{array}$ \\
\hline
\end{tabular}


DRIII HOLE H-7 Cont'd

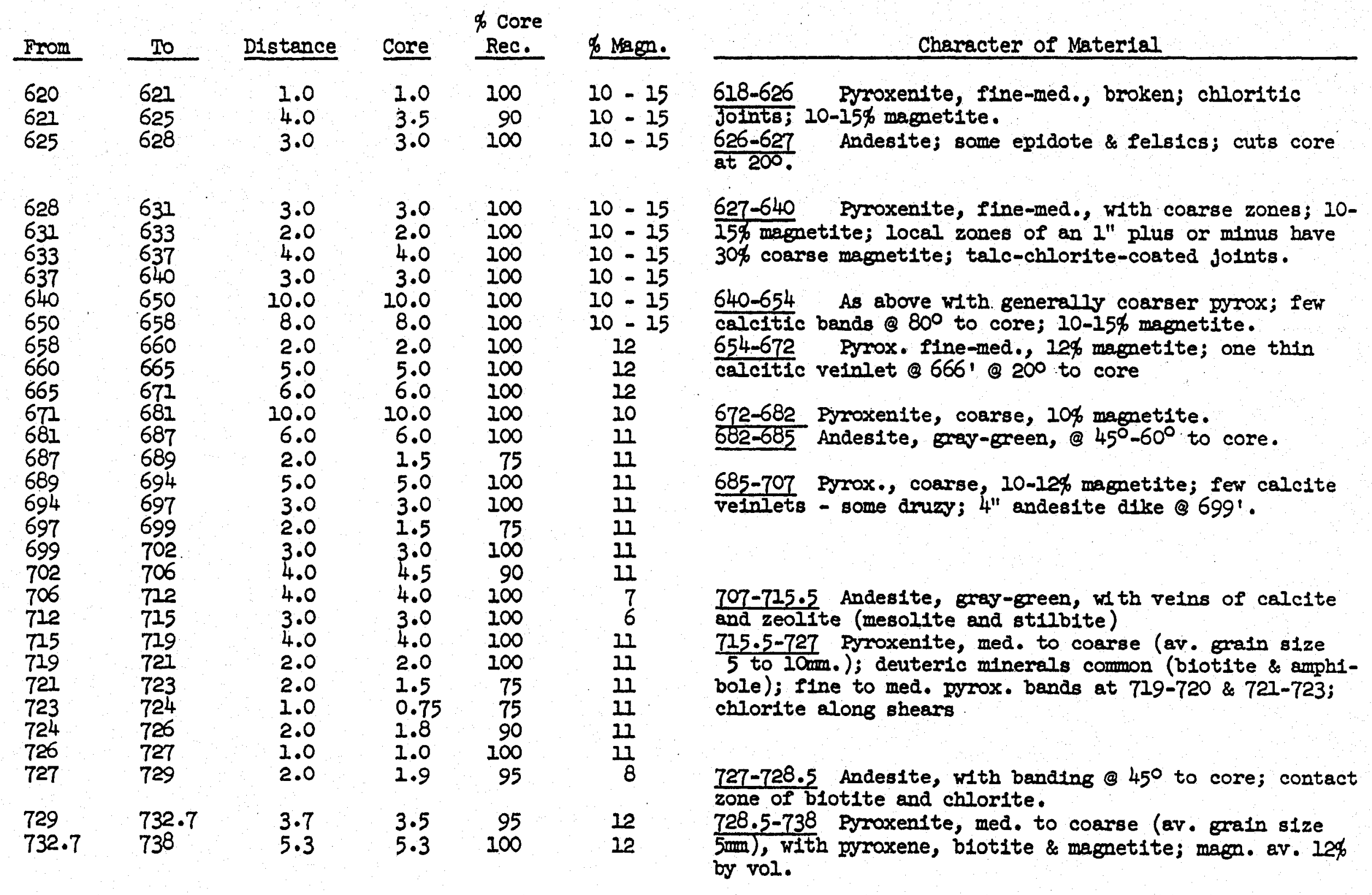


DRIIL HOLE H-7 Cont'd

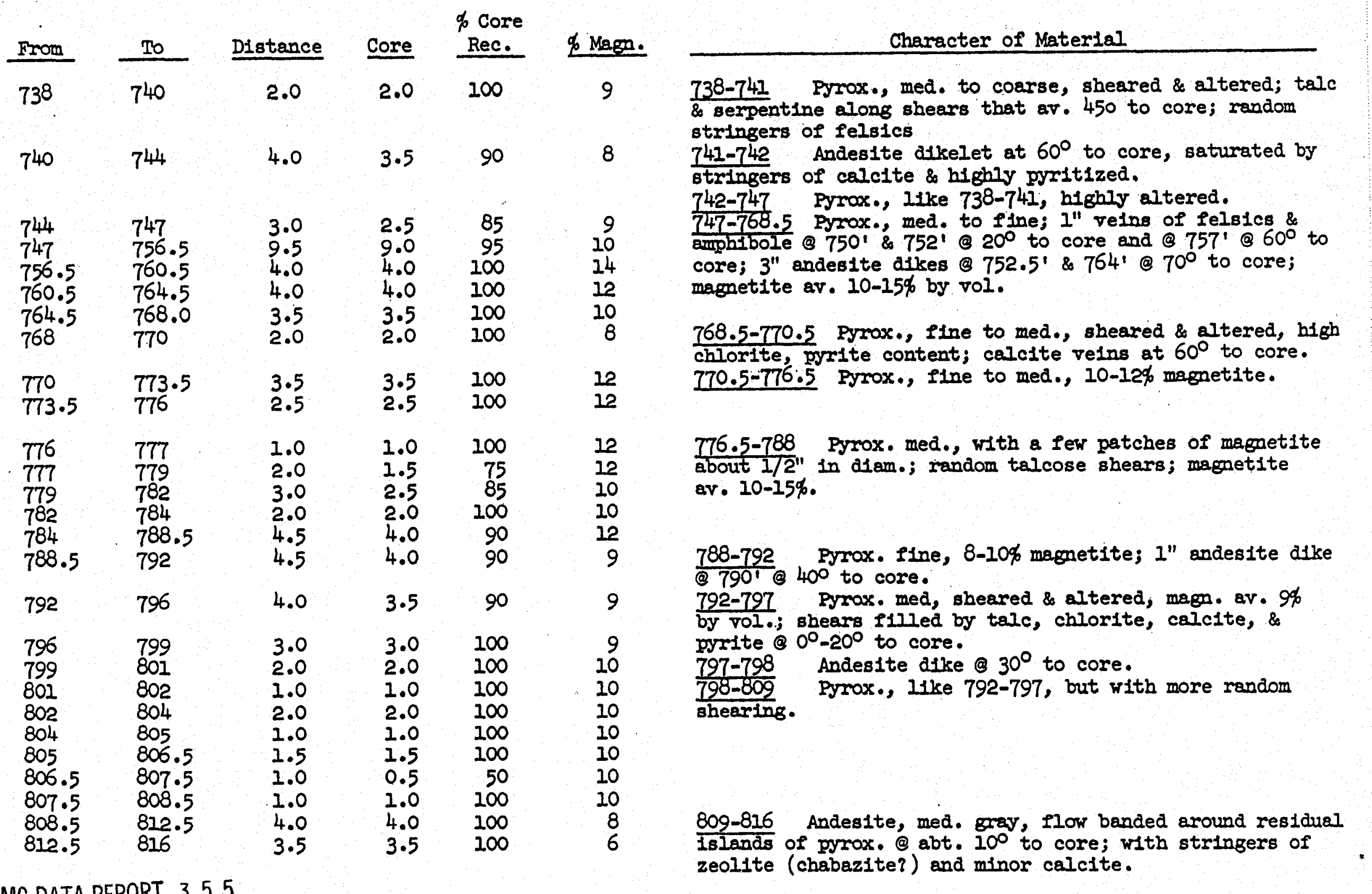




\begin{tabular}{|c|c|c|c|c|c|}
\hline From & To & Distance & Core & $\begin{array}{c}\$ \text { Core } \\
\text { Rec. }\end{array}$ & \% Magn. \\
\hline $\begin{array}{l}816 \\
818 \\
821.5 \\
824 \\
825 \cdot 5 \\
827 \cdot 5 \\
830 \\
833\end{array}$ & $\begin{array}{l}818 \\
821 \cdot 5 \\
824 \\
825 \cdot 5 \\
827 \cdot 5 \\
830 \\
833 \\
837.5\end{array}$ & $\begin{array}{l}2.0 \\
3.5 \\
2.5 \\
1.5 \\
2.0 \\
2.5 \\
3.0 \\
4.5\end{array}$ & $\begin{array}{l}2.0 \\
3.0 \\
2.0 \\
1.5 \\
1.5 \\
2.0 \\
3.0 \\
4.5\end{array}$ & $\begin{array}{r}100 \\
90 \\
80 \\
100 \\
75 \\
80 \\
100 \\
100\end{array}$ & $\begin{array}{r}9 \\
10 \\
10 \\
10 \\
12 \\
12 \\
12 \\
7\end{array}$ \\
\hline $\begin{array}{l}837 \cdot 5 \\
839\end{array}$ & $\begin{array}{l}839 \\
849\end{array}$ & $\begin{array}{r}2.5 \\
10.0\end{array}$ & $\begin{array}{l}0.5 \\
2.0\end{array}$ & $\begin{array}{l}33 \\
20\end{array}$ & $\begin{array}{r}10 \\
9\end{array}$ \\
\hline $\begin{array}{l}849 \\
852.5\end{array}$ & $\begin{array}{l}852.5 \\
856.5\end{array}$ & $\begin{array}{l}3.5 \\
4.0\end{array}$ & $\begin{array}{l}3.0 \\
4.0\end{array}$ & $\begin{array}{r}90 \\
100\end{array}$ & $\begin{array}{l}6 \\
7\end{array}$ \\
\hline
\end{tabular}

$\begin{array}{llllll}856.5 & 857.5 & 1.0 & 1.0 & 100 & 12 \\ 857.5 & 858.5 & 1.0 & 1.0 & 100 & 12 \\ 858.5 & 861 & 2.5 & 2.5 & 100 & 12 \\ 861 & 862.5 & 1.5 & 1.0 & 66 & 11 \\ 862.5 & 864.5 & 2.0 & 2.0 & 100 & 9 \\ 864.5 & 866.5 & 2.0 & 2.0 & 100 & 10 \\ 866.5 & 870 & 3.5 & 3.5 & 100 & 12 \\ 870 & 879 & 9.0 & 9.0 & 100 & 12 \\ 879 & 889 & 10.0 & 10.0 & 100 & 13\end{array}$

GMC DATA REPORT 355

825.5-834 Pyrox., I1ne to med.; chlorite-pyrite-11]led av. $12 \%$ by vol. 834-837 Andest

(3) 200 to core; contect al med. gray, no llow banding; (a) upper contact only

$\frac{837-847}{3 y}$ Pyrox., fine to med., (broken and rounded by tumbling in core barrel); av. 10-12\% magnetite by 847-854 Andesite like 834-837'; Irregurar, digitate contect with the pyrox.

854-855.5 Fyrox:, fine, highly fractured with no Geralization along tractures.

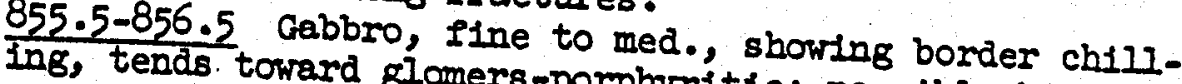
metamorphosed sed. with porphyritic; possibly bigbly

856.5-865 Pyrox., fine to med., highly fractured is (8) $10^{8}$ to core.

$865-890$ andesite alke \& $86{ }^{\prime}$ ' 6 , relatively unfractured; $I^{\prime \prime}$ velnlet 8870 \& $30^{\circ}$ to $60^{\circ}$ to core; amphibole-filled abundant apatite \& to core; $2 "$ dike of andesite with Fine grained pyrox. av $10-15 \%$ (3) $10^{\circ}$ to core. zones of coarser av. 10-15\% magn. by vol.; a few (8) $877^{\prime}$ (a) 100 to core. 
DRIIC HOLE H-7 Cont'd

\begin{tabular}{llllll} 
From & To & Distance & Core & $\begin{array}{c}\text { \% Core } \\
\text { Rec. }\end{array}$ & \% Magn. \\
\cline { 4 - 6 } 889 & 899 & 10.0 & 10.0 & 100 & 10 \\
& & & & & \\
899 & 905 & 6.0 & 6.0 & 100 & 11 \\
905 & 907 & 2.0 & 2.0 & 100 & 10 \\
907 & 911.5 & 4.5 & 4.0 & 90 & 12 \\
911.5 & 921 & 9.5 & 9.5 & 100 & 11 \\
921 & 924 & 3.0 & 3.0 & 100 & 13
\end{tabular}

$\begin{array}{llllll}924 & 931 & 7.0 & 7.0 & 100 & 12 \\ 931 & 933 & 2.0 & 2.0 & 100 & 11 \\ 933 & 934.5 & 1.5 & 1.0 & 66 & 11 \\ 934.5 & 939 & 4.5 & 4.5 & 100 & 12 \\ 939 & 940.5 & 1.5 & 1.0 & 66 & 12 \\ 940.5 & 943 & 2.5 & 2.0 & 80 & 12 \\ 943 & 946 & 3.0 & 3.0 & 100 & 12 \\ 946 & 950 & 4.0 & 4.0 & 100 & 11 \\ 950 & 952.5 & 2.5 & 2.5 & 100 & 11 \\ 952.5 & 956 & 3.5 & 3.0 & 85 & 11 \\ 956 & 961.5 & 5.5 & 5.5 & 100 & 10 \\ 961.5 & 964 & 2.5 & 2.5 & 100 & 11 \\ & & & & & \\ 964 & 968 & 4.0 & 4.0 & 100 & 12 \\ 968 & 978 & 10.0 & 10.0 & 100 & 11 \\ 978 & 985.5 & 7.5 & 7.5 & 100 & 11\end{array}$
$\frac{923-941}{11}$ Pyrox., fine, av $10-14 \%$ magnetfte; talc-
$\frac{12}{11}$ chiorite Pliled shears @ $0^{\circ}-10^{\circ}$ \& $@ 30-50$ to core.
941-944 Pyrox., med., randomly sheared, av. 10-12\% magnetite with veinlets of blotite.
244-964 Pyrox., IIne, av. 11\% magn.; talc-chlorite- filled fractures @ 30-45 to core \& chlorite-calcite- pyrite filled fractures \& 60-80 to core; 6" fine grained dike (8) 956.5 andesite dike (B) 955.5' @ $65^{\circ}$ to core; $I^{\prime \prime}$ dike (3) 956.5' (9) $75^{\circ}$ to core, 6" dike (s) $957.5^{\prime}$ () $50^{\circ}$ to $55^{\circ}$ to core.
964-985 Pyrox., fine, av. 12\% magnetite, relatively crystals, av. 8-10\% of coarse pyrox. whth large apatite

890-892 Pyrox., med., Grain size av. 2-3 m.; fresh and unfractured, Bradational contact with fine grained pyrox. ( $45^{\circ}$ to core, av. $10 \%$ magnetite. 892-920 Pyrox. IIne, minor fracturing, av. 12-15\% magnetite by VOL.; zones of med. to coarse pyrox. \& 905'-906.5', 907.5-908', \& 914'-915'; av. 8-12\% magn. Bhow increase in $\%$ of biotite \& amphibole (in veinlets dark abray $40^{\circ}$ to core. Andesfte dikes, fine, flow-banded, to core. 220-923 Pyrox., med. to coarse, av. $12 \%$ magnetite; 1/2 magnetite seam \& $2^{\prime \prime}$ amphibole seam at 921 ' (3) $35^{\circ}$ to core; $2^{\prime \prime}$ zone of coarse pyrox. av. $25 \%$ magnetite a 922' \& $25^{\circ}$ to core. 


\begin{tabular}{|c|c|c|c|c|c|}
\hline From & To & Distance & Core & $\begin{array}{c}\text { \% Core } \\
\text { Rec. }\end{array}$ & o Magn. \\
\hline $\begin{array}{c}985.5 \\
994 \\
999 \\
1001 \\
1005\end{array}$ & $\begin{array}{l}994.0 \\
999 \\
1001 \\
1005 \\
1009\end{array}$ & $\begin{array}{l}8.5 \\
5.0 \\
2.0 \\
4.0 \\
4.0\end{array}$ & $\begin{array}{l}8.5 \\
5.0 \\
2.0 \\
4.0 \\
4.0\end{array}$ & $\begin{array}{l}100 \\
100 \\
100 \\
100 \\
100\end{array}$ & $\begin{array}{l}11 \\
12 \\
12 \\
12 \\
10\end{array}$ \\
\hline $\begin{array}{l}1009 \\
1011 \\
1014 \\
1024 \\
1028\end{array}$ & $\begin{array}{l}1011 \\
1014 \\
1024 \\
1028 \\
1032.5\end{array}$ & $\begin{array}{r}2.0 \\
3.0 \\
10.0 \\
4.0 \\
4.5\end{array}$ & $\begin{array}{c}1.75 \\
3.0 \\
10.0 \\
4.0 \\
4.5\end{array}$ & $\begin{array}{l}85 \\
100 \\
100 \\
100 \\
100\end{array}$ & $\begin{array}{l}9 \\
10 \\
10 \\
10 \\
11\end{array}$ \\
\hline $\begin{array}{l}1032 \cdot 5 \\
1036 \\
1041 \\
1045 \\
1048 \\
1049.5 \\
1050.5 \\
1054 \\
1055 \\
1065 \\
1069 \\
1071 \\
1074 \\
1075 \cdot 5 \\
1082 \\
1089 \\
1094 \\
1102 \\
1110 \\
1111\end{array}$ & $\begin{array}{l}1036 \\
1041 \\
1045 \\
1048 \\
1049.5 \\
1050.5 \\
1054 \\
1055 \\
1065 \\
1069 \\
1071 \\
1074 \\
1075.5 \\
1082 \\
1089 \\
1094 \\
1102 \\
1110 \\
1111 \\
1115.5\end{array}$ & $\begin{array}{r}3.5 \\
5.0 \\
4.0 \\
3.0 \\
1.5 \\
1.0 \\
3.5 \\
1.0 \\
10.0 \\
4.0 \\
2.0 \\
3.0 \\
1.5 \\
6.5 \\
7.0 \\
5.0 \\
8.0 \\
8.0 \\
1.0 \\
4.5\end{array}$ & $\begin{array}{l}3.5 \\
5.0 \\
4.0 \\
3.0 \\
1.5 \\
1.0 \\
3.5 \\
1.0 \\
10.0 \\
4.0 \\
2.0 \\
3.0 \\
1.5 \\
6.0 \\
7.0 \\
5.0 \\
7.5 \\
8.0 \\
1.0 \\
4.0\end{array}$ & $\begin{array}{l}100 \\
100 \\
100 \\
100 \\
100 \\
100 \\
100 \\
100 \\
100 \\
100 \\
100 \\
100 \\
100 \\
95 \\
100 \\
100 \\
95 \\
100 \\
100 \\
90\end{array}$ & $\begin{array}{l}10 \\
11 \\
11 \\
11 \\
11 \\
11 \\
11 \\
11 \\
12 \\
12 \\
12 \\
10 \\
12 \\
11 \\
11 \\
12 \\
12 \\
12 \\
12 \\
12\end{array}$ \\
\hline
\end{tabular}


DRIIL HOLE H-7 Cont'd

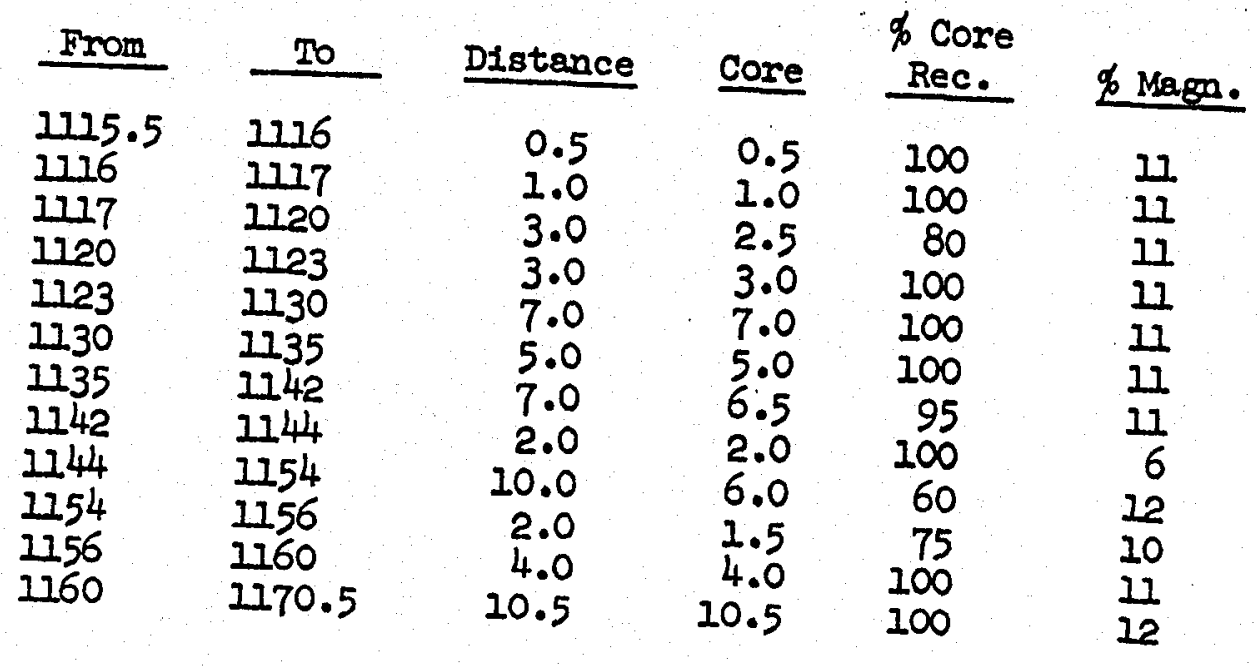

$\begin{array}{llrrrr}1170.5 & 1172 & 1.5 & 1.5 & 100 & 12 \\ 1172 & 1173 & 1.0 & 1.0 & 100 & 12 \\ 1173 & 1175 & 2.0 & 1.5 & 75 & 10 \\ 1175 & 1176 & 1.0 & 1.0 & 100 & 10 \\ 1176 & 1177 & 1.0 & 1.0 & 100 & 12 \\ 1177 & 1179 & 2.0 & 1.5 & 75 & 12 \\ 1179 & 1180 & 1.0 & 12 & 50 & 12 \\ 1180 & 1191 & 11.0 & 2.0 & 20 & 12 \\ 1191 & 1197 & 6.0 & 6.0 & 100 & 12 \\ 1197 & 1200.5 & 3.5 & 3.5 & 100 & 12 \\ 1200.5 & 1202.5 & 2.0 & 1.5 & 75 & 12 \\ 1202.5 & 1205 & 2.5 & 2.5 & 100 & 10 \\ 1205 & 1215 & 10.0 & 10.0 & 100 & 10 \\ 1215 & 1222 & & & & 10\end{array}$

GMC DATA REPORT 355

1115-1143 Pyrox. fine to med., av. 11\% magnetite by coated and (3) $45^{\circ}-80^{\circ}$ to pyxite filled.

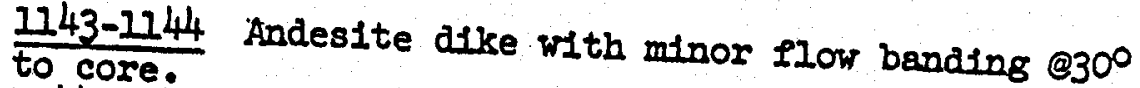

$1744-1146$

1146-1148 Pyrox., I1ne, av. 12\% magnetite.

by vol. Pyrox., coarse, (av. 5-10 m.); av. $11 \%$ magn.

1148-1168

magnetite by vol.; sheared, relatively unfractured, av. 11\% (8) 1154'-1155'; 4"' sheared, chlont1zed \& serpentinized oreenish gray ( 11161.5 a 200 to grained diorite dike $1168-1170$ Pymox

patches; $2^{\prime \prime}$ seam of mase with a few Interstitial felsic 1170-1173.5 gym il69'.

av. $13 \%$ manetite. $1773.5-1176$ Pyra.

abundant sheartox., coarse, Iike 1168-1170', but w1th

1176-1192 Pyrax, fine, highly sheared (chlorite-

serpentine-coated); av. 12\% masnetite.

1192-1211 Pyrax,, IIne, with minor fracturing; ar. 12\% (9) 1204 (3) $75^{\circ}$ to core; \& 2" dike (2) $1207^{\prime \prime} 1203^{\prime} ; I^{\prime \prime}$ dike 1211-1214.5 Pyroxe; \& dike (8) 1207' (3) $70^{\circ}$ to core. blotite.

1214.5-1218 Pyrox., coarse, w1th crystals as large 1218-1001 felsic patches \& velnlets; av. $10 \%$ magn. IIo magnetIte, wrox., med, relatively unfractured, av. bole crystals. 
DRIIC HOLE H-7 Cont'd

\begin{tabular}{lllllll} 
From & To & Distance & Core & \% Core & Rec. & \% Nagn. \\
\cline { 1 - 2 } 1222 & 1223.5 & 1.5 & 1.5 & 100 & 12 \\
1223.5 & 1225 & 1.5 & 1.5 & 100 & 12 \\
1225 & 1226 & 1.0 & 1.0 & 100 & 12 \\
1226 & 1227 & 1.0 & 1.0 & 100 & 12 \\
1227 & 1228 & 1.0 & 1.0 & 100 & 12 \\
1228 & 1230.5 & 2.5 & 2.5 & 100 & 12 \\
1230.5 & 1232.5 & 2.0 & 1.5 & 75 & 12 \\
1232.5 & 1240 & 7.5 & 7.5 & 100 & 5
\end{tabular}

$\begin{array}{llllll}1240 & 1242 & 2.0 & 2.0 & 100 & 12 \\ 1242 & 1244.5 & 2.5 & 2.5 & 100 & 6 \\ 1244.5 & 1251 & 6.5 & 6.5 & 100 & 5 \\ 1251 & 1256 & 5.0 & 5.0 & 100 & 6 \\ 1256 & 1257.5 & 1.5 & 1.0 & 70 & 12 \\ 1257.5 & 1261.5 & 4.0 & 4.0 & 100 & 12 \\ 1261.5 & 1263 & 1.5 & 1.5 & 100 & 6 \\ 1263 & 1267 & 4.0 & 4.0 & 100 & 6\end{array}$

1232.5-1238 Dlorite to monzonite, light gray, fine to medium greined; consists of plagioclase \& alkall feldspar, amphibole (occasionally in large crystals--10m... and crystal clots) biotite, minor magnetite and quartz; plagloclase \& amphibole crystals show some flow alignment (s) 300-400 to core; dike cuts pyrox. (c) $15^{\circ}$. 1238-1242.5 Pyrox., fine to med., highly fractured; av. $12 \%$ masnetite.

1242.5-1244 Andesite, dark gray, flow banded; intrudes both the pyrox. \& the diorite to monzonite.

1244-1255 Diorite to monzonite, like 1232.5'-1238', but with some chlorite \& pyrite along rare fractures.

1255-1260 Pyroxenite, fIne, with abundant chloriteanalcite-filled fractures; av. 12\% magnetite by vol. 1260-1261 Diorite to monzonite, IIne, cuts pyrax. (9) $25^{\circ}$. 1261-1263 Pyrox., fine, highly fractured. 1263-1267 Andesite, dark greenish gray, 1low banded; velins of amphibole-chlorite-epldote-pyrite-carbonate are cut by velns of mesolite-carbonate.

$\begin{array}{llllll}1267 & 1268 & 1.0 & 1.0 & 100 & 12 \\ 1268 & 1269.5 & 1.5 & 1.5 & 100 & 11 \\ 1269.5 & 1271 & 1.5 & 1.5 & 100 & 12 \\ 1271 & 1272.5 & 1.5 & 0.5 & 30 & 12 \\ 1272.5 & 1273 & 0.5 & 0.5 & 100 & 12 \\ 1273 & 1274 & 1.0 & 1.0 & 100 & 12 \\ 1274 & 1276 & 2.0 & 1.0 & 50 & 12 \\ 1276 & 1276.5 & 0.5 & 0.5 & 100 & 12 \\ 1276.5 & 1279 & 2.5 & 2.5 & 100 & 11 \\ 1279 & 1280.5 & 1.5 & 1.5 & 100 & 12\end{array}$

1267-1287 Pyrox., Ifne to med., with abundant, random shears; ar. 12\% magnetite; coarse phase (a) 1268'-1269' \& () $1277^{\prime}$; sheared \& chloritized @ $1283.5^{\prime}-1284.5^{\prime}$.

GIVIL UAIA REPORT $355 \quad$ Page $84 / 189$ 
DRTH HOLE H-7 COnt'd

\begin{tabular}{|c|c|c|c|c|c|}
\hline From & To & Distance & Core & $\begin{array}{c}\% \text { Core } \\
\text { Rec. }\end{array}$ & of Magn. \\
\hline $\begin{array}{l}1280.5 \\
1282 \\
1284.5 \\
1285.5 \\
1287\end{array}$ & $\begin{array}{l}1282 \\
1284.5 \\
1285.5 \\
1287 \\
1291.5\end{array}$ & $\begin{array}{l}1.5 \\
2.5 \\
1.0 \\
1.5 \\
4.5\end{array}$ & $\begin{array}{l}1.5 \\
2.0 \\
1.0 \\
1.5 \\
4.0\end{array}$ & $\begin{array}{r}100 \\
80 \\
100 \\
100 \\
90\end{array}$ & $\begin{array}{c}\frac{12}{11} \\
\frac{12}{12} \\
6\end{array}$ \\
\hline $\begin{array}{l}1291.5 \\
1293.5 \\
1296 \\
1298\end{array}$ & $\begin{array}{l}1293 \cdot 5 \\
1296 \\
1298 \\
1302\end{array}$ & $\begin{array}{l}2.0 \\
2.5 \\
2.0 \\
4.0\end{array}$ & $\begin{array}{l}2.0 \\
2.5 \\
2.0 \\
3.5\end{array}$ & $\begin{array}{r}100 \\
100 \\
100 \\
90\end{array}$ & $\frac{11}{11}$ \\
\hline 1302 & 1312 & 10.0 & 10.0 & 100 & 8 \\
\hline
\end{tabular}

1287-1290. Andesite, dark gray, distinctly flow banded, bordered by $2^{\prime \prime}$ felsic band at upper contact \& $I^{\prime}$ band at lower contact (1289'-1290'). 1290-1302.5 Pyrox., fine, with abundant fractures (8) $200-450$ to core \& some chlorite-calcite filled shears (3) 700-80 to core; $3^{\prime \prime}$ andesite dike (c) 1299 (\&) $75^{\circ}$ to core; av. 11\% magnet1te by rol.

1302.5-1304 Andes1te, Iike 1287-1290, \& $20^{\circ}$ to core. 1304-1306.5 Pyrox., fine to med.; unfractured; av. 11\% magnetite; $1 "$ felsic band (B 1305.5 \& $25^{\circ}$ to core \& another (a) $1306^{\prime}$ \& $35^{\circ}$ to core.

1306.5-1308 Andes1te, Iike 1302.5-1304', \& $45^{\circ}$ to core. 1308-1316.5 Pyrox., fine, unfractured, av. 12\% magn.;

$\begin{array}{llllll}1312 & 1314 & 2.0 & 2.0 & 100 & 12 \\ 1314 & 1322.5 & 8.5 & 8.5 & 100 & 11 \\ 1322.5 & 1323.5 & 1.0 & 1.0 & 100 & 10 \\ 1323.5 & 1332 & 8.5 & 8.5 & 100 & 10\end{array}$
1/4" felsic veinlets \& $10-25^{\circ}$ to core.

1316.5-1319 Pyrox., coarse, unfractured, ar. 11\% magn. by vol.; saturated with felsics (s) 1318'-1319'.

1319-1333 Pyrax. Iine to med., randomly fractured (3) 1321'-1322' \& 1327'-1329'; av. 10\% magnet1te; 1/4" felsic veinlets cut core (B) $25^{\circ}$; $4^{\prime \prime}$ andesite dike () 1320 (1) 800 to core.

$\begin{array}{llllll}1332 & 1339 & 7.0 & 7.0 & 100 & 10 \\ 1339 & 1342 & 3.0 & 3.0 & 100 & 12 \\ 1342 & 1344.5 & 2.5 & 2.5 & 100 & 11 \\ 1344.5 & 1354 & 9.5 & 9.5 & 100 & 10\end{array}$

1333-1335 Pyrox., coarse, unfractured w1th patches \& velnlets of felsics.

1335-1352.5 Pyrox., fine to med., minor frecturing (B) 0 $-30^{\circ}$ to core; ar. ilo magnetite by vol; $1 / 2^{\prime \prime}$ ragged veinlet of magnetite \& blotite () 1339.5

1352.5-1355 Pyrox., coarse to very coarse (crystals as large as $50 \mathrm{~mm}$ ); felsic patches; magnetite av $8 \%$ by
vol.

GMC DATA REPORT 355 
DRII HOLE H-7 Cont'a

\begin{tabular}{|c|c|c|c|c|c|c|}
\hline From & To & Distance & Core & $\begin{array}{l}\text { o Core } \\
\text { Rec. }\end{array}$ & of Magn. & Character of Material \\
\hline 1354 & 1360.5 & 6.5 & 6.5 & 100 & 8 & $\begin{array}{l}\frac{1355-1357}{1337-1358} \text { Ayrox.; fine, unfractured. } \\
\frac{1358-1361}{1351} \text { Ayrox., coarse to very coarse, Iike } 1352.5^{\prime}\end{array}$ \\
\hline 1360.5 & 1368 & $7 \cdot 5$ & $7 \cdot 5$ & 100 & 9 & 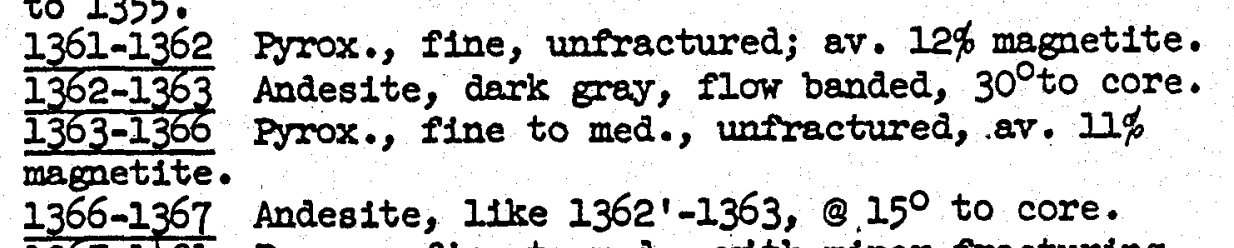 \\
\hline $\begin{array}{l}1368 \\
1378 \\
1385 \\
1386.5 \\
1390 \\
1392\end{array}$ & $\begin{array}{l}1378 \\
1385 \\
1386.5 \\
1390 \\
1392 \\
1401\end{array}$ & $\begin{array}{r}10.0 \\
7.0 \\
1.5 \\
3.5 \\
2.0 \\
9.0\end{array}$ & $\begin{array}{r}10.0 \\
7.0 \\
1.5 \\
3.5 \\
2.0 \\
8.0\end{array}$ & $\begin{array}{l}100 \\
100 \\
100 \\
100 \\
100 \\
90\end{array}$ & $\begin{array}{l}13 \\
12 \\
12 \\
12 \\
12 \\
12\end{array}$ & 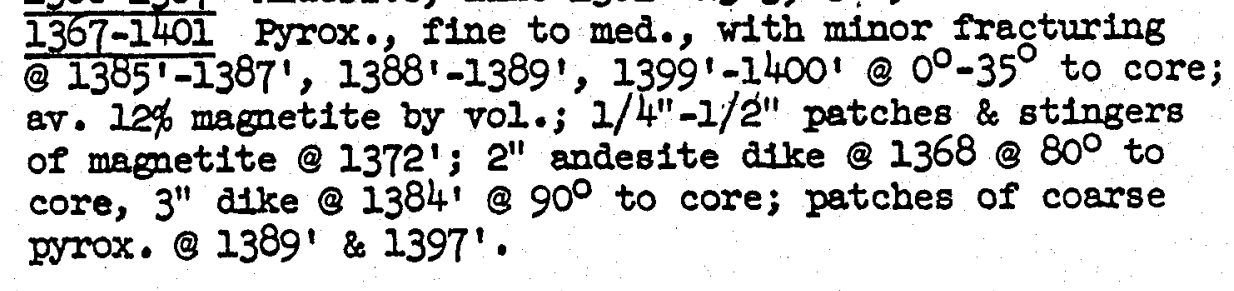 \\
\hline 1401 & 1412.5 & 10.5 & 4.0 & 40 & 6 & $\begin{array}{l}\text { 1401-1409 Andesite, cut by veins of carbonate \& pyrite; } \\
\text { coarser phase has } 5 \text { m. pseudomorphs of serpentine- } \\
\text { chlorite after ollivine (?). }\end{array}$ \\
\hline $\begin{array}{l}1412.5 \\
1415\end{array}$ & $\begin{array}{l}1415 \\
1425\end{array}$ & $\begin{array}{r}3.5 \\
10.0\end{array}$ & $\begin{array}{r}3.5 \\
10.0\end{array}$ & $\begin{array}{l}100 \\
100\end{array}$ & $\frac{21}{10}$ & $\begin{array}{l}\frac{1409-1417}{\text { magnetite. }} \text { Pyrox., I1ne, relatively unfractured; av. } 11 \% \\
1417-1419 \text { Pyrox., med. to coarse, with a few felsic }\end{array}$ \\
\hline $\begin{array}{l}1425 \\
1428 \\
1434\end{array}$ & $\begin{array}{l}1428 \\
1434 \\
1439.5\end{array}$ & $\begin{array}{l}3.0 \\
6.0 \\
5.5\end{array}$ & $\begin{array}{l}3.0 \\
6.0 \\
5.5\end{array}$ & $\begin{array}{l}100 \\
100 \\
100\end{array}$ & $\begin{array}{l}15 \\
13 \\
10\end{array}$ & $\begin{array}{l}\text { patches; av } 8 \% \text { magnetite. } \\
1419-1435.5 \text { Pyrox., fine, relatively unfractured, av. } \\
3 \% \text { magnetite; } 2^{\prime \prime} \text { felsic vein @ } 1420^{\prime} \text { @ } 15^{\circ} \text { to core; } \\
1 / 4^{\prime \prime} \text { zeolite-amphibole velnlet @ } 1425^{\prime} \text { @ } 10^{\circ} \text { to core; } \\
1 / 4^{\prime \prime}-1 / 2^{\prime \prime} \text { magnetite petches @ } 1427^{\prime} \text {. }\end{array}$ \\
\hline & & & & & & 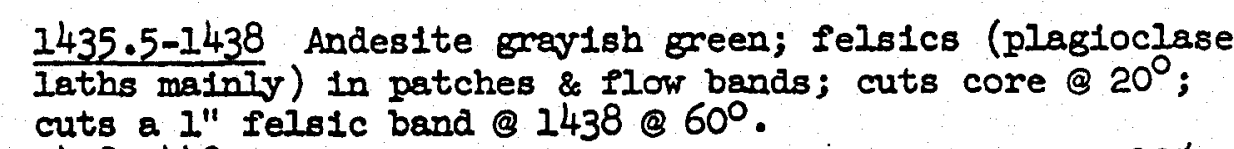 \\
\hline $\begin{array}{l}1439 \cdot 5 \\
1441 \\
1445\end{array}$ & $\begin{array}{l}1441 \\
1445 \\
1448\end{array}$ & $\begin{array}{l}1.5 \\
4.0 \\
3.0\end{array}$ & $\begin{array}{l}1.0 \\
3.5 \\
3.0\end{array}$ & $\begin{array}{r}70 \\
90 \\
100\end{array}$ & $\frac{12}{12} 12$ & 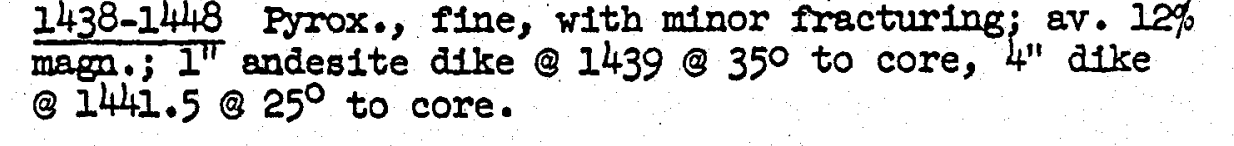 \\
\hline \multicolumn{7}{|c|}{ GMC DATA REPORT 355} \\
\hline
\end{tabular}


DRIIL HOLE H-7 Cont'd

\begin{tabular}{|c|c|c|c|c|c|c|}
\hline From & To & Distance & Core & $\begin{array}{l}\% \text { Core } \\
\text { Rec. }\end{array}$ & o Magn. & Character of Material \\
\hline 2448 & 1451.5 & 3.5 & 3.5 & 100 & 12 & $\begin{array}{l}\text { 1448-1452 Pyrox., med., av. } 12 \% \text { magnetite; Intruded } \\
\text { along lower contact with fine pyrox. (a) } 1452 \text { ' by andesite } \\
\text { dike \& } 10^{\circ} \text { to core. }\end{array}$ \\
\hline $\begin{array}{l}1451.5 \\
1457 \\
1459 \cdot 5 \\
1463.5 \\
1473\end{array}$ & $\begin{array}{l}1457 \\
1459 \cdot 5 \\
1463 \cdot 5 \\
1473 \\
1479\end{array}$ & $\begin{array}{l}5.5 \\
2.5 \\
4.0 \\
9.5 \\
6.0\end{array}$ & $\begin{array}{l}4.0 \\
2.5 \\
4.0 \\
9.5 \\
6.0\end{array}$ & $\begin{array}{l}75 \\
100 \\
100 \\
100 \\
100\end{array}$ & $\begin{array}{l}11 \\
13 \\
\frac{11}{11}\end{array}$ & $\begin{array}{l}1452-1459.5 \text { Pyrox., fine, relatively unfractured; av. } \\
13 \% \text { magmetite; } 1^{\prime \prime} \text { andesite dike @ } 1455.5^{\prime} \text { @ } 90^{\circ} \text { to core, } \\
2^{\prime \prime} \text { dike @ } 1457^{\prime} \text { @ } 75^{\circ} \text { to core. } \\
1459.5-1478 \text { Pyrox., fine, saturated by numerous } 1 / 4^{\prime \prime} \\
\text { to } 2^{\prime} \text { dikes of andesite to trachyandesite; dikes are } \\
\text { 1rregular \& random in orlentation. }\end{array}$ \\
\hline $\begin{array}{l}1479 \\
1481.5 \\
1485 \\
1488\end{array}$ & $\begin{array}{l}1481.5 \\
1485 \\
1488 \\
1493\end{array}$ & $\begin{array}{l}2.5 \\
3.5 \\
3 \cdot 0 \\
5.0\end{array}$ & $\begin{array}{l}2.5 \\
3.5 \\
3.0 \\
5.0\end{array}$ & $\begin{array}{l}100 \\
100 \\
100 \\
100\end{array}$ & $\begin{array}{l}13 \\
13 \\
13 \\
8\end{array}$ & 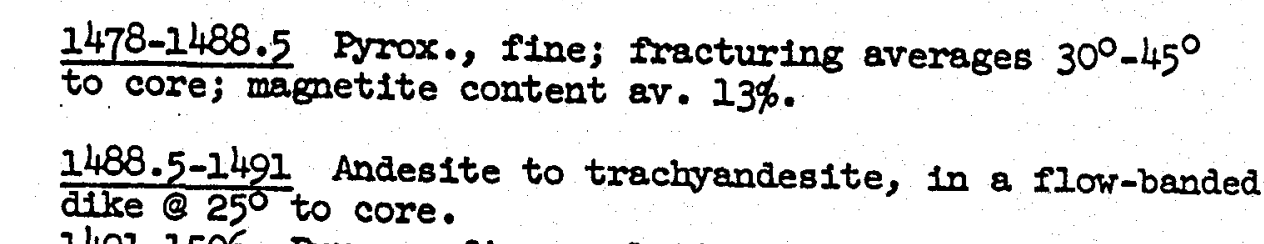 \\
\hline $\begin{array}{l}1493 \\
1502 \\
1509 \\
1511.5 \\
1515 \\
1519 \\
1520 \\
1522 \\
1525 \\
1528 \\
1530 \\
1536 \\
1538 \\
1540 \\
1542 \\
1544 \\
1546 \\
1547 \\
1551 \\
1556\end{array}$ & $\begin{array}{l}1502 \\
1509 \\
1511 \cdot 5 \\
1515 \\
1519 \\
1520 \\
1522 \\
1525 \\
1528 \\
1530 \\
1536 \\
1538 \\
1540 \\
1542 \\
1544 \\
1546 \\
1547 \\
1551 \\
1556 \\
1560\end{array}$ & $\begin{array}{l}9.0 \\
7.0 \\
2.5 \\
3.5 \\
4.0 \\
1.0 \\
2.0 \\
3.0 \\
3.0 \\
2.0 \\
6.0 \\
2.0 \\
2.0 \\
2.0 \\
2.0 \\
2.0 \\
1.0 \\
4.0 \\
5.0 \\
4.0\end{array}$ & $\begin{array}{l}9.0 \\
7.0 \\
2.5 \\
3.5 \\
3.5 \\
1.0 \\
2.0 \\
3.0 \\
3.0 \\
2.0 \\
6.0 \\
2.0 \\
2.0 \\
1.5 \\
2.0 \\
2.0 \\
1.0 \\
4.0 \\
5.0 \\
4.0\end{array}$ & $\begin{array}{l}100 \\
100 \\
100 \\
100 \\
90 \\
100 \\
100 \\
100 \\
100 \\
100 \\
100 \\
100 \\
100 \\
75 \\
100 \\
100 \\
100 \\
100 \\
100 \\
100\end{array}$ & $\begin{array}{l}11 \\
11 \\
10 \\
10 \\
11 \\
11 \\
11 \\
11 \\
10 \\
11 \\
11 \\
11 \\
11 \\
11 \\
11 \\
11 \\
11 \\
11 \\
11 \\
10\end{array}$ & 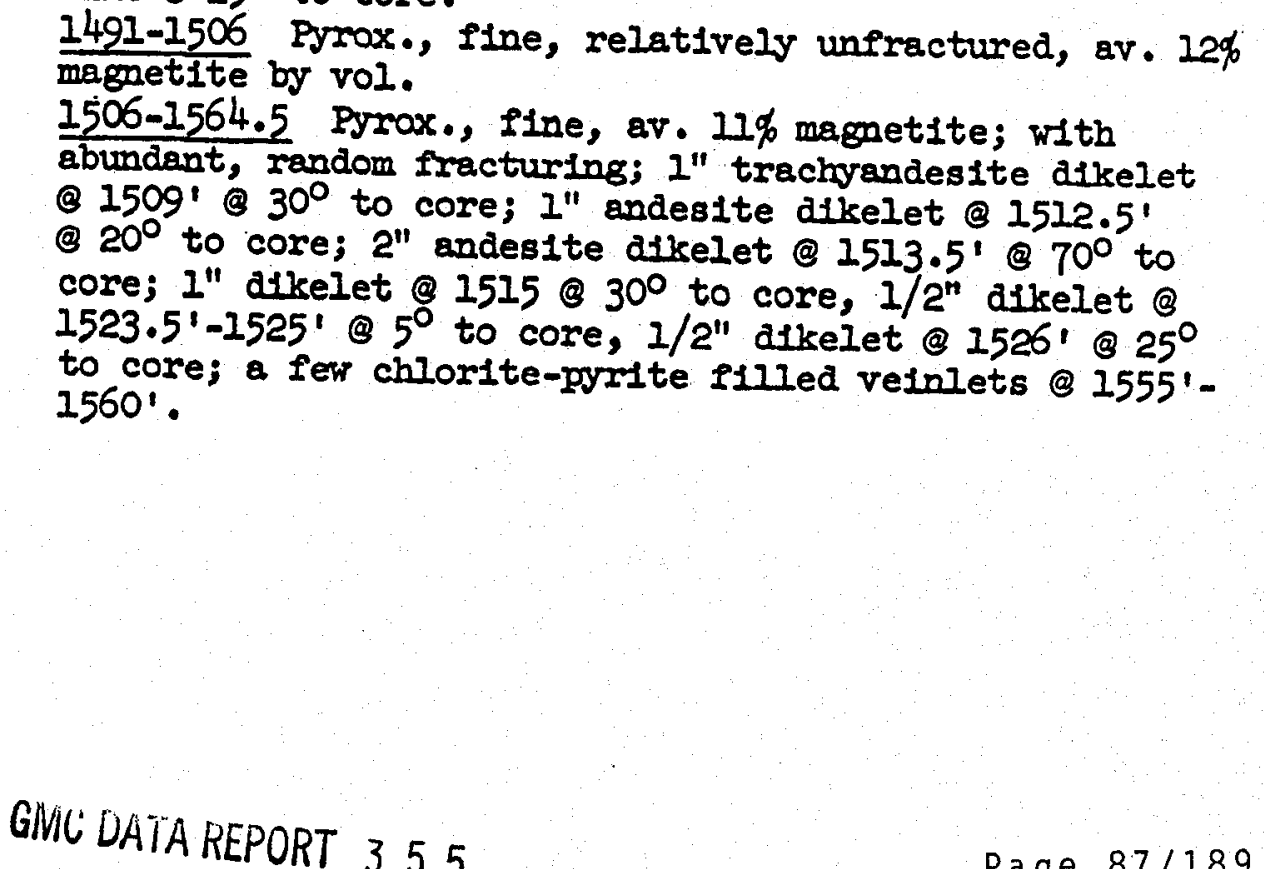 \\
\hline & & & & & & IC DATA REPORT 355 \\
\hline
\end{tabular}


DRITL HOLE E-7 Cont'd

$\begin{array}{llllll}\text { Fram } & \text { To } & \text { D1stance } & \text { Core } & \begin{array}{c}\text { \% Core } \\ \text { Rec. }\end{array} & \text { q Magn. } \\ 1560 & 1568.5 & 8.5 & 8.5 & 100 & 11 \\ & & & & & \\ 1568.5 & 1572 & 3.5 & 3.5 & 100 & 12 \\ 1572 & 1576.5 & 4.5 & 4.5 & 100 & 12 \\ 1576.5 & 1579.5 & 3.0 & 3.0 & 100 & 12 \\ 1579.5 & 1589.5 & 10.0 & 10.0 & 100 & 14 \\ 1589.5 & 1598 . & 8.5 & 8.5 & 100 & 11\end{array}$

$\begin{array}{llllll}1598 & 1602 & 4.0 & 4.0 & 100 & 11 \\ 1602 & 1608 & 6.0 & 6.0 & 100 & 11 \\ 1608 & 1610.5 & 2.5 & 2.5 & 100 & 11 \\ 1610.5 & 1612.5 & 2.0 & 2.0 & 100 & 11 \\ 1612.5 & 1617 & 4.5 & 4.5 & 100 & 11 \\ 1617 & 1624 & 7.0 & 7.0 & 100 & 6 \\ 1624 & 1625 & 1.0 & 1.0 & 100 & 12 \\ 1625 & 1629 & 4.0 & 4.0 & 100 & 12 \\ 1629 & 1635 & 6.0 & 6.0 & 100 & 12 \\ 1635 & 1639 & 4.0 & 4.0 & 100 & 12 \\ 1639 & 1646 & 7.0 & 7.0 & 100 & 10 \\ 1646 & 1652.5 & 6.5 & 6.5 & 100 & 12 \\ 1652.5 & 1655 & 3.5 & 3.0 & 85 & 12 \\ 1655 & 1658 & 3.0 & 3.0 & 100 & 12 \\ 1658 & 1660 & 2.0 & 2.0 & 100 & 12 \\ 1660 & 1664.5 & 4.5 & 4.5 & 100 & 11 \\ 1664.5 & 1666.5 & 2.0 & 2.0 & 100 & 10 \\ 1666.5 & 1669 & 2.5 & 2.5 & 100 & 12 \\ 1669 & 1672 & 3.0 & 3.0 & 100 & 12 \\ 1672 & 1676.5 & 4.5 & 4.5 & 100 & 14 \\ 1676.5 & 1678 & 1.5 & 1.0 & 70 & 13 \\ 1678 & 1680 & 2.0 & 2.0 & 100 & 12 \\ 1680 & 1684 & 4.0 & 2.0 & 50 & 12 \\ 1684 & 1687 & 3.0 & 3.0 & 100 & 12 \\ 1687 & 1688.5 & 1.5 & 1.0 & 70 & 12 \\ 1688.5 & 1692 & 3.5 & 3.5 & 100 & 13 \\ & & & & \end{array}$

GMC DATA REPORT 355

Character of Material

1564.5-1567.5 Pyrox., coarse to med., with patches of

1567.5-1587.5 Pyrax. fine, w1th: some chlorite-talc fllled fractures o $10^{8}-40^{\circ}$ to core; av. $12 \%$ magnetite; 2 Beam of magnetite (s) $1587^{\prime}$ \& $80^{\circ}$ to core.

$\frac{1587.5-1596.5}{17 \%}$ Pyrox., med. to coarse, unfractured, av. $I^{\prime \prime}$ andesite dite; felsics in patches \& scattered veinlets; carbonat dikelet \& 1593 \& $45^{\circ}$ to core; $1^{\prime \prime}$ chloriteadjecent tite.

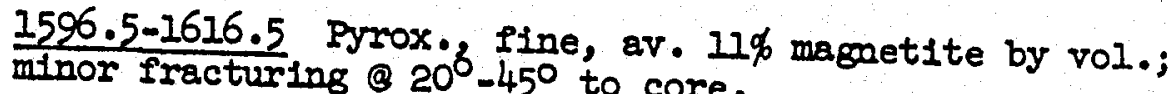

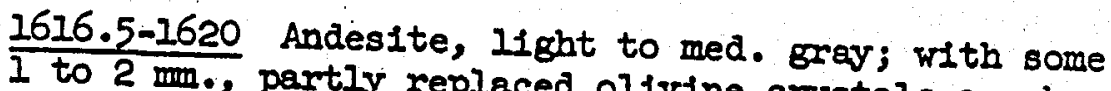
i to 2 m., partly replaced olivine crystals as pheno1620-1639 the pyroxenite in a miltitude of dikelets. to core; av. 12\% , fine w1th minor fracturing o $40^{\circ}-500$ $30^{\circ}$ to core.

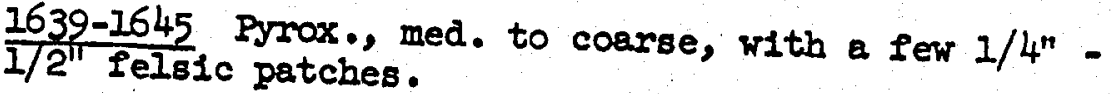

1645-1662 Pyrox., fine, w1th a few med. to coarse patches; $8 \mathrm{gv}$. $12 \%$ magnet1te.

1662-1666 Pyrox., fine, with talcose shears (a) $10^{\circ}-30^{\circ}$ to core and abundant, thin veinlets of epidote, chlorite $1666-1676$ pyrite $345^{\circ}$ to core.

1666-1676 .Pyrox.' fine, with minor fracturing; magnet1te to core. $1676-1707$

ab. 12\% magn.1 5"' Iine, with abundant, random fractures; 2" dikelet (8) 168I' \& $50^{\circ}$ to dikelet \& $1680^{\prime}$ \& $90^{\circ}$ to core, $1685^{\prime}$ (3) $40^{\circ}$ to core, $I^{\prime \prime}$ to core, $2^{\prime \prime}$ andesite dikelet (s) dikelet (3 1695' \& $70^{\circ}$ to dikelet (a) 1693' \& 80 to core, $I^{\prime \prime}$ velnlets. 
DRIIL HOLE H-7 COnt' $d$

\begin{tabular}{|c|c|c|c|c|c|}
\hline From & To & Distance & Core & $\begin{array}{c}\text { of Core } \\
\text { Rec. }\end{array}$ & \& Magn. \\
\hline $\begin{array}{l}1692.0 \\
1695 \\
1697.5 \\
1701 \\
1704 \\
1706 \\
1710.5 \\
1728 \\
1722 \\
1724.5 \\
1729 \\
1730.5 \\
1735 \\
1738.5 \\
1744 \\
1746.5 \\
1750 \\
1752 \\
1756.5\end{array}$ & $\begin{array}{l}1695.0 \\
1697 \cdot 5 \\
1701 \\
1704 \\
1706 \\
1710.5 \\
1718 \\
1722 \\
1724.5 \\
1729 \\
1730.5 \\
1735 \\
1738.5 \\
1744 \\
1746.5 \\
1750 \\
1752 \\
1756.5 \\
1759\end{array}$ & $\begin{array}{l}3.0 \\
2.5 \\
3.5 \\
3.0 \\
2.0 \\
4.5 \\
7.5 \\
4.0 \\
2.5 \\
4.5 \\
1.5 \\
4.5 \\
3.5 \\
5.5 \\
2.5 \\
3.5 \\
2.0 \\
4.5 \\
2.5\end{array}$ & $\begin{array}{l}3.0 \\
2.5 \\
3.5 \\
2.5 \\
2.0 \\
4.5 \\
7.5 \\
4.0 \\
2.5 \\
4.5 \\
1.5 \\
4.5 \\
3.5 \\
5.5 \\
2.5 \\
3.5 \\
2.0 \\
4.0 \\
2.5\end{array}$ & $\begin{array}{r}100 \\
100 \\
100 \\
80 \\
100 \\
100 \\
100 \\
100 \\
100 \\
100 \\
100 \\
100 \\
100 \\
100 \\
100 \\
100 \\
100 \\
90 \\
100\end{array}$ & $\begin{array}{r}13 \\
12 \\
13 \\
13 \\
12 \\
6 \\
12 \\
12 \\
12 \\
12 \\
12 \\
11 \\
12 \\
13 \\
10 \\
11 \\
13 \\
13 \\
12\end{array}$ \\
\hline
\end{tabular}

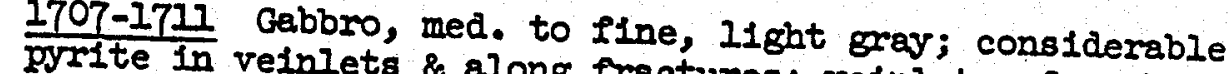
ate \& zeolite (s $45^{\circ}$ to along fractures; velnlets of carbon-

1711-1731 Pyroxentte, fine with a few med. to coarse ate epidote veinlet @ $1719^{\prime}$ @ $50^{\circ}-70^{\circ}$ to core; $3^{\prime \prime}$ carbon列

1731-1735.5 Pyrox., fine, with an altered zone (to epidote \& chlorite) (a) $5^{\circ}$ to core. $1735.5-1756.5$ Pyrax., flne, with moderate, random fracturIng; ar. 13\% magn. by vol.; Ilght to med. gray andesite to trachyandesite dikelets (a) $1744^{\prime} 5^{\prime}$ \& $45^{\circ}$ to core (a $1746.5^{\prime}$ (3) $20^{\circ}$ to core \& \& $1749^{\prime}-2750^{\prime}$ \& $40^{\circ}$ to core, contain conminute pyrite, disseminated \& along fractures, and minute traces of chalcopyrite, also some thin limonite filled veinlets (rare).

1756.5-1759 Pyrox., fine, with minute flakes of native copper disseminated and along fractures (probably less than 0.01\%); 4" andesite alkel contains both andesite dikelet (a) 1757.5 ! () $30^{\circ}$ to core contains both pyrite \& nat1re copper (trace). magnetite.

1770.5-1775 Gabbro, 11ght gray, med., cut by dikelets of andesite; both contain serpentine-chlorite pseudomorphs both contain which are surrounded by reaction coronas; 1775-1812

$\frac{1775-1812}{12 y r o x ., ~ f i n e, ~ w i t h ~ m o d e r a t e, ~ r a n d o m ~ f r a c t u r i n g ; ~}$ core is darketite; 4" andesite dikelet () 1811' \& $70^{\circ}$ to core is dark gray, flow-banded with minor pyrite; 4" andesite dikelet @ 1811. $5^{\prime}$ @ $65^{\circ}$ to core. 


\begin{tabular}{|c|c|c|c|c|c|}
\hline From & To & Distance & Core & $\begin{array}{c}\text { o Core } \\
\text { Rec. } \\
\end{array}$ & of Magn \\
\hline $\begin{array}{l}1790.5 \\
1793 \\
1796 \\
1797 \\
1799 \\
1803 \\
1806 \\
1810 \\
1811.5 \\
1812 \\
1815 \\
1820.5 \\
1825\end{array}$ & $\begin{array}{l}1793 \\
1796 \\
1797 \\
1799 \\
1803 \\
1806 \\
1810 \\
1811.5 \\
1812 \\
1815 \\
1820.5 \\
1825 \\
1828\end{array}$ & $\begin{array}{l}2.5 \\
3.0 \\
1.0 \\
2.0 \\
4.0 \\
3.0 \\
4.0 \\
1.5 \\
0.5 \\
3.0 \\
5.5 \\
4.5 \\
3.0\end{array}$ & $\begin{array}{l}2.5 \\
3.0 \\
1.0 \\
2.0 \\
3.5 \\
3.0 \\
4.0 \\
1.5 \\
0.5 \\
3.0 \\
5.5 \\
4.5 \\
3.0\end{array}$ & $\begin{array}{r}100 \\
100 \\
100 \\
100 \\
90 \\
100 \\
100 \\
100 \\
100 \\
100 \\
100 \\
100 \\
100\end{array}$ & $\begin{array}{l}\frac{11}{11} \\
\frac{11}{11} \\
12 \\
12 \\
11 \\
10 \\
11 \\
11 \\
10 \\
11 \\
11\end{array}$ \\
\hline $\begin{array}{l}1828 \\
1831 \\
1836 \\
1838 \\
1839 \\
1841 \\
1842.5 \\
1843.5 \\
1844.5 \\
1847 \\
1848 \\
1851.5 \\
1856 \\
1858 \\
1861 \\
1865 \\
1871 \\
1876\end{array}$ & $\begin{array}{l}1831 \\
1836 \\
1838 \\
1839 \\
1841 \\
1842.5 \\
1843.5 \\
1844.5 \\
1847 \\
1848 \\
1851.5 \\
1856 \\
1858 \\
1861 \\
1865 \\
1871 \\
1876 \\
1886\end{array}$ & $\begin{array}{l}3.0 \\
5.0 \\
2.0 \\
1.0 \\
2.0 \\
1.5 \\
1.0 \\
1.0 \\
2.5 \\
1.0 \\
3.5 \\
4.5 \\
2.0 \\
3.0 \\
4.0 \\
6.0 \\
5.0 \\
10.0\end{array}$ & $\begin{array}{l}3.0 \\
5.0 \\
1.5 \\
1.0 \\
1.5 \\
1.5 \\
1.0 \\
1.0 \\
2.5 \\
1.0 \\
3.5 \\
4.5 \\
2.0 \\
3.0 \\
4.0 \\
6.0 \\
5.0 \\
10.0\end{array}$ & $\begin{array}{r}100 \\
100 \\
75 \\
100 \\
75 \\
100 \\
100 \\
100 \\
100 \\
100 \\
100 \\
100 \\
100 \\
100 \\
100 \\
100 \\
100 \\
100\end{array}$ & $\begin{array}{l}12 \\
12 \\
12 \\
12 \\
12 \\
12 \\
12 \\
12 \\
12 \\
12 \\
12 \\
12 \\
12 \\
8 \\
12 \\
10 \\
12 \\
11\end{array}$ \\
\hline
\end{tabular}

1812-1827 Pyrox., fine, as above but with thin, random veinlets of chlorite, carbonate, epidote, \& pyrite; av. $11 \%$ magnetite; $I^{\prime}$ andesite to trachyandesite dikelet () $1815.5^{\prime}-1816.5^{\prime}$ \& $55^{\circ}$ to core contains pyrite disseminated \& in velniets with epldote \& carbonates; $3^{\prime \prime}$ dikelet (a) $1824.5^{i}$ contains a trace of chalcopyrite along with pyrite, epidote \& carbonate. 1827-1876 Pyrox., fine, with random fracturing; av. 12\% magnetite; andesite dikelet (a 1858'-1860' @ 5 $5^{\circ}$ to core with pyrite along frectures \& along contact with pyrox.; $2^{\prime \prime}$ dikelet (c) $1863^{\prime}$ (s) $50^{\circ}$ to core; serles of $1^{\prime \prime}$ dikes (a) 1867 1868' cut by stilbite-filled fracture.

1876-1880 Pyrox., fine, cut by mumerous velniets of chlorite, carbonate \& pyrite, increasing in number approaching the dikelet (a) $1880^{\prime}$. 
DRITL HOLE H-7 Cont'a

\begin{tabular}{|c|c|c|c|c|c|}
\hline From & To & Distance & Core & $\begin{array}{l}6 \text { Core } \\
\text { Rec. } \\
\end{array}$ & of Magn. \\
\hline $\begin{array}{l}1886 \\
1888 \\
1890 \\
1891.5 \\
1893 \\
1894.5 \\
1897 \cdot 5 \\
1900.5 \\
1902 \\
1903.5 \\
1906.5 \\
1907 \\
1910 \\
1911 \\
1912 \\
1916 \\
1919 \\
1922 \\
1923 \\
1928 \\
1933 \\
1935 \\
1939\end{array}$ & $\begin{array}{l}1888 \\
1890 \\
1891.5 \\
1893 \\
1894.5 \\
1897 \cdot 5 \\
1900.5 \\
1902 \\
1903.5 \\
1906.5 \\
1907 \\
1910 \\
1911 \\
1912 \\
1916 \\
1919 \\
1922 \\
1923 \\
1928 \\
1933 \\
1935 \\
1939 \\
1940\end{array}$ & $\begin{array}{l}2.0 \\
2.0 \\
1.5 \\
1.5 \\
1.5 \\
3.0 \\
3.0 \\
1.5 \\
1.5 \\
3.0 \\
0.5 \\
3.0 \\
1.0 \\
1.0 \\
4.0 \\
3.0 \\
3.0 \\
1.0 \\
5.0 \\
5.0 \\
2.0 \\
4.0 \\
1.0\end{array}$ & $\begin{array}{l}2.0 \\
2.0 \\
1.5 \\
1.5 \\
1.5 \\
3.0 \\
3.0 \\
1.0 \\
1.0 \\
3.0 \\
0.5 \\
3.0 \\
1.0 \\
1.0 \\
3.5 \\
3.0 \\
3.0 \\
1.0 \\
5.0 \\
5.0 \\
2.0 \\
4.0 \\
1.0\end{array}$ & $\begin{array}{r}100 \\
100 \\
100 \\
100 \\
100 \\
100 \\
100 \\
70 \\
70 \\
100 \\
100 \\
100 \\
100 \\
100 \\
90 \\
100 \\
100 \\
100 \\
100 \\
100 \\
100 \\
100 \\
100\end{array}$ & $\begin{array}{l}11 \\
11 \\
11 \\
11 \\
11 \\
11 \\
11 \\
11 \\
11 \\
11 \\
10 \\
10 \\
10 \\
11 \\
11 \\
11 \\
11 \\
11 \\
6 \\
12 \\
12 \\
14 \\
12\end{array}$ \\
\hline $\begin{array}{l}1940 \\
1942 \\
1943.5 \\
1945.5 \\
1946.5 \\
1948 \\
1950 \\
1950.5 \\
1952.5 \\
1953 \\
1955.5 \\
1956.5 \\
1957.5\end{array}$ & $\begin{array}{l}1942 \\
1943.5 \\
1945.5 \\
1946.5 \\
1948 \\
1950 \\
1950.5 \\
1952.5 \\
1953 \\
1955.5 \\
1956.5 \\
1957.5 \\
1958.5\end{array}$ & $\begin{array}{l}2.0 \\
1.5 \\
2.0 \\
1.0 \\
1.5 \\
2.0 \\
0.5 \\
2.0 \\
0.5 \\
2.5 \\
1.0 \\
1.0 \\
1.0\end{array}$ & $\begin{array}{l}2.0 \\
1.0 \\
1.5 \\
1.0 \\
1.5 \\
1.5 \\
0.5 \\
1.5 \\
0.5 \\
2.5 \\
1.0 \\
0.5 \\
1.0\end{array}$ & $\begin{array}{r}100 \\
70 \\
75 \\
100 \\
100 \\
75 \\
100 \\
75 \\
100 \\
100 \\
100 \\
50\end{array}$ & $\begin{array}{l}12 \\
12 \\
12 \\
12 \\
12 \\
12 \\
12 \\
12 \\
10 \\
12 \\
12 \\
12\end{array}$ \\
\hline 1957.5 & 1958.5 & 1.0 & 1.0 & 100 & 12 \\
\hline
\end{tabular}

Character of Material

1880-1882 Andesite to trachyandesite dikelet, light 8ray, \& $50^{\circ}$ to core, with minor pyrite.

1882-1923.5 Pyrox., IIne, fracturing av. 300-60 to core; av. Il\% magnet1te; 2" amphtbole-felsic vein Q 1908 i $35^{\circ}$ to core.

1923.5-1928 Andesite, 11ght gray, cut by veinlets of carbonate and zeolite (stilblte); bordered by dark gray andesite.

1928-2000 Pyrox., Iine, w1th moderate, random fracturing av. 12\% magnetite by vol.; I" seam of magnetite @ 1938'; $4^{\prime \prime}$ andesite to trachyandesite dikelet (s) 1954' a $40^{\circ}$ to core contains considerable pyrite; 4 " andesite dikelet (a) $1978.5^{\prime}$ \& $75^{\circ}$ to core; $3^{\prime \prime}$ andesite dlkelet (3) $1992^{\prime}$ (8) $40^{\circ}$ to core; 4" andesite dikelet @ 1993! @ 400 to core $2^{\prime \prime}$ dikelet \& 1996' @ $20^{\circ}$ to core; group of $I^{\prime \prime}$ amphibolefelsic velnlets \& 1996.5'-1998'.

GMC DATA REPORJ 355

Page $91 / 189$ 
DRILL HOLE H-7 Cont'd

\begin{tabular}{|c|c|c|c|c|c|c|}
\hline From & To & Distance & Core & $\begin{array}{l}\text { of Core } \\
\text { Rec. }\end{array}$ & of Magn. & Character of Materlal \\
\hline $\begin{array}{l}1958.5 \\
1960.5 \\
1965 \\
1966 \\
1968 \\
1970.5 \\
1972.5 \\
1974 \\
1977 \\
1979.5 \\
1982 \\
1983.5 \\
1987 \\
1990 \\
1992 \\
1996 \\
1999\end{array}$ & $\begin{array}{l}1960.5 \\
1965 \\
1966 \\
1968 \\
1970.5 \\
1972.5 \\
1974 \\
1977 \\
1979.5 \\
1982 \\
1983.5 \\
1987 \\
1990 \\
1992 \\
1996 \\
1999 \\
2000\end{array}$ & $\begin{array}{l}2.0 \\
4.5 \\
1.0 \\
2.0 \\
2.5 \\
2.0 \\
1.5 \\
3.0 \\
2.5 \\
2.5 \\
1.5 \\
3.5 \\
3.0 \\
2.0 \\
4.0 \\
3.0 \\
1.0\end{array}$ & $\begin{array}{l}2.0 \\
4.0 \\
1.0 \\
2.0 \\
1.5 \\
2.0 \\
1.5 \\
3.0 \\
2.5 \\
2.5 \\
1.5 \\
3.5 \\
3.0 \\
2.0 \\
4.0 \\
3.0 \\
1.0\end{array}$ & $\begin{array}{l}100 \\
90 \\
100 \\
100 \\
60 \\
100 \\
100 \\
100 \\
100 \\
100 \\
100 \\
100 \\
100 \\
100 \\
100 \\
100 \\
100\end{array}$ & $\begin{array}{l}12 \\
12 \\
12 \\
12 \\
12 \\
12 \\
11 \\
12 \\
10 \\
12 \\
12 \\
11 \\
11 \\
12 \\
10 \\
12 \\
12\end{array}$ & \\
\hline
\end{tabular}

(BOTTOM OF HOLE) 
Started: June 4, 1959

Completed: June 21, 1959

Elevation (collar reference H-2- 664 )

Located 825 ' south of north center line stake of XI2; thence 25' east

\begin{tabular}{|c|c|c|c|c|c|}
\hline From & To & Distance & Core & $\begin{array}{c}\text { \% Core } \\
\text { Rec. }\end{array}$ & $\begin{array}{c}\phi \\
\text { Magn. }\end{array}$ \\
\hline 0 & 8 & 8 & 0 & & \\
\hline 8 & 40 & 32 & 0 & & \\
\hline 40 & 50 & 10 & 0 & & \\
\hline 50 & 100 & 50 & 0 & & \\
\hline 100 & 120 & 20 & 0 & & \\
\hline 120 & 217 & 97 & 0 & & \\
\hline 217 & 222.5 & 5.5 & 0 & & \\
\hline $\begin{array}{l}222 \\
224 \\
228 \\
235 \\
245 \\
246 \\
251 \\
254\end{array}$ & $\begin{array}{l}224 \\
228 \\
235 \\
245 \\
246 \\
251 \\
254 \\
257\end{array}$ & $\begin{array}{r}2 \\
4 \\
7 \\
10 \\
1 \\
5 \\
3 \\
3\end{array}$ & $\begin{array}{l}2 \\
4 \\
7 \\
10 \\
.75 \\
5^{2} .5 \\
3\end{array}$ & $\begin{array}{r}100 \\
100 \\
100 \\
100 \\
75 \\
100 \\
80 \\
100\end{array}$ & $\begin{array}{r}10 \\
11 \\
11 \\
9 \\
14 \\
14 \\
14 \\
14\end{array}$ \\
\hline
\end{tabular}

Character of Material

(Rock bit 3-7/8") Tundra and peat.

Sand with gravel lenses and beds, brown.

Gravel, coarse with sand.

Sand with gravel layers - some water bearing.

Gravel, coarse and sand.

Gravel, coarse with sand, cobbles and boulders.

Sludge indicates firm rock with appreciable magnetite. Pyroxentte ledge at $217^{\prime \prime}$ (NX-casing set to 222').

222-235.5 Pyroxenite, fine grained, gray1sh green; magnetite av. $21 \%$ by vol.; native copper (possibly av. $0.02 \%$ ) is in thin sheets up to $l^{\prime \prime}$ in diam. along random fractures; minor pyrite is finely disseminated; shears at $30^{\circ}-45^{\circ}$ to core are coated by chlorite \& serpentine; $1 / 2^{\prime \prime}-1$ " bands of massive chlorite @233'-234' are spotted by pseudomorphs of limonite after pyrite; 1 " band of solid magnetite @234.5' (s) 900 to core.

235.5-237.5 Gabbro, coarse grained (av. 3mm.), with about $60 \%$ pyroxene and $30 \%$ felsic minerals (partly serfcltized plagloclase, apatite \& minor carbonate). Felsics are interstitial to the pyroxene. Magnetite av. $7 \%$ by vol.

237.5-240 Pyroxenite, eine; magnetite av. $14 \%$ by vol. 
240-241.5 Gabbro, like 235.5-237.5; appears to have intruded the pyroxenite, cutting the core (3) $25^{\circ}$. 241.5-254.5 Pyroxentte, fine; magnetite av. $15 \%$ by vol; random chlorite-pyrite-f1lied shears; anphibolerich zone (s) 252 contains microlitic cavities lined by zeolites \& pyrite; $I^{\prime \prime}$ band of magnetite @ $250^{\prime}$.

$\begin{array}{llllll}257 & 259 & 2 & 1 & 50 & 10 \\ 259 & 264 & 5 & 5 & 100 & 9 \\ 264 & 266.5 & 2.5 & 2.5 & 100 & 6 \\ 266.5 & 271 & 4.5 & 4 & 90 & 11 \\ 271 & 276 & 5 & 5 & 100 & 13 \\ 276 & 280 & 4 & 4 & 100 & 13 \\ 280 & & & & & \\ 281 & 281 & 1 & 1 & 100 & 12 \\ 285.5 & 285.5 & 4.5 & 4.5 & 100 & 10 \\ & 290.5 & 5 & 5 & 100 & 19\end{array}$

254.5-263 Pyroxentte, Ifne, velned \& altered; native copper disseminated along fractures (possibly 0.01-0.02\%); magnetite av. $10 \%$ by vol.; 1/2" chlorite velns () $300^{-}$ $50^{\circ}$ to core contain limonite pseudomorphs after pyrite. 263-266 Pyroxenite, fine, saturated by veins of felsics (altered plagloclase, apatite, etc.); av. $8 \%$ magnetite by vol. 266-286 Pyroxenite, fine, av. 12\% magnetite by vol.; cut by veinlets (3 $45^{\circ}-90^{\circ}$ to core of chlorite-calcitepyrite; Broup of $1 / 2$ " patches of magnetite (S 274' \& 277 '; patches of felsic@ 282 '-284'along w1th chlorite, calcite, and pyrite.

$\begin{array}{llllll}290.5 & 295.5 & 5 & 5 & 100 & 16 \\ 295.5 & 300 & 4.5 & 4.5 & 100 & 18 \\ 300 & 304 & 4 & 4 & 100 & 16 \\ 304 & 305 & 1 & 1 & 100 & 17 \\ 305 & 310 & 5 & 4.5 & 90 & 17 \\ 310 & 315 & 5 & 5 & 100 & 10 \\ 315 & 320 & 5 & 5 & 100 & 10 \\ 320 & 325 & 5 & 5 & 100 & 16 \\ 325 & 329 & 4 & 4 & 100 & 11\end{array}$

$329 \quad 333$

333
338

$\begin{array}{rrrr}4 & 3.5 & 90 & 11 \\ 5 & 5 & 100 & 10\end{array}$

286-310.5 Pyroxenite, fine; increase in magnetite content 1s apparent (av. 17\% by rol.); 1 " bands of magnetite @ 286.5', $290^{\prime}, 297^{\prime}, 307^{\prime} ; 1 / 2^{\prime \prime}$ felsic velnlets (C) $295^{\prime}$.

310.5-320 Pyroxenite, fine, with coarse phase (1) 310.5311.5 ; felsic bands: $2^{\prime \prime}$ () $313^{\prime}$ @ $65^{\circ}$ to core, 313.5 \$50 to core, $314^{\prime}$ (a) $40^{\circ}$ to core, $324.5^{\prime}$ \& $30^{\circ}$ to core, \& (3) $315^{\prime}-317.5^{\prime}$.

320-325 Pyroxentte, fine, wth $I^{\prime \prime}$ seams of magnetite

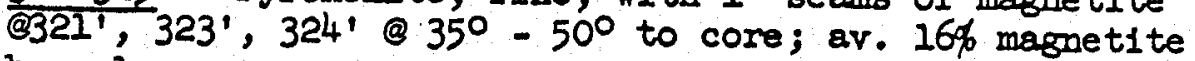
by rol.

333 
DRILL HOLE E-8

\begin{tabular}{|c|c|c|c|c|c|}
\hline From & To & Distance & Core & $\begin{array}{c}\text { \% Core } \\
\text { Rec. }\end{array}$ & ${ }_{\text {Magn }}^{\phi}$ \\
\hline $\begin{array}{l}338 \\
340 \\
350 \\
359 \\
369 \\
375 \\
381.5\end{array}$ & $\begin{array}{l}340 \\
350 \\
359 \\
369 \\
375 \\
381.5 \\
385\end{array}$ & $\begin{array}{c}2 \\
10 \\
9 \\
10 \\
6 \\
6.5 \\
3.5\end{array}$ & $\begin{array}{c}1.5 \\
10 \\
9 \\
10 \\
6 \\
6.5 \\
3\end{array}$ & $\begin{array}{r}75 \\
100 \\
100 \\
100 \\
100 \\
100 \\
85\end{array}$ & $\begin{array}{l}11 \\
10 \\
10 \\
11 \\
11 \\
10 \\
12\end{array}$ \\
\hline
\end{tabular}

$\begin{array}{rrrrrr}385 & 387 & 2 & 2 & 100 & 12 \\ 387 & 392 & 5 & 4 & 80 & 12 \\ 392 & 397 & 5 & 4 & 80 & 11 \\ 397 & 402 & 5 & 4.5 & 90 & 7 \\ 402 & 407 & 5 & 5 & 100 & 12 \\ 407 & 411 & 4 & 3.5 & 80 & 8 \\ 411 & 412 & 1 & .75 & 75 & 6 \\ 412 & 413 & 1 & 1 & 100 & 6\end{array}$

$\begin{array}{llllll}413 & 419.5 & 6.5 & 6.5 & 100 & 7 \\ 419.5 & 421.5 & 2 & 1.5 & 75 & 6 \\ 421.5 & 422 & 0.5 & 0.25 & 50 & 6 \\ 422 & 432 & 10 & 10 & 100 & 5 \\ 432 & 435.5 & 3.5 & 3.5 & 100 & 6 \\ 435.5 & 437.5 & 2 & 1.5 & 75 & 6 \\ 437.5 & 440 & 2.5 & 2.5 & 100 & 6 \\ 440 & 443 & 3 & 3 & 100 & 6 \\ 443 & 446 & 3 & 3 & 100 & 6\end{array}$

GMC DATA REPORT 355

thin veinlets; chlorite-calcite-pyrite in $1 / 4^{\prime \prime}-1 / 2^{\prime \prime}$ veln-

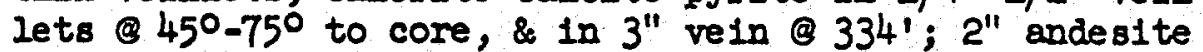
dike (2331' @ 200 to core.

349-370.5 Pyroxenite, fine, with epidote veined coarse phase ब34 $9^{\prime}-350.5^{\prime}$; abundant, random, $1 / 2^{\prime \prime}$ velns of fels1cs; chlorite-pyrite-calcite-rich zone (S 361'-362.5'; amphibolerich veins (3) $358^{\prime}$ (a) $300-50^{\circ}$ to core contain pyrite \& some chalcopyrite.

370.5-375.5 Pyroxentte, fine to coarse, sheared (random) and chloritized. Coarse phase, $373^{\prime}-375.5^{\prime}$ av. 5 m. In grain olze, av. 11\% magnetite by vol., \& 1s velned by chlorite \& epldote.

375.5-396 Pyroxenste, fine, av. 12\% magnet1te; a few veins of chlorite, epldote, calcite \& pyrite, felsicrlch band (gabbro) \& $380.5^{\prime}-381.5^{\prime}$ (c) $20^{\circ}$ to core.

396-403.5 Gabbro, med. to coarse (av. 3 to $5 \mathrm{~mm}$.); av. $50 \%$ felsic \& $7 \%$ magnetite by vol.; $8^{\prime \prime}$ felsic band 9403. The gabbro cuts the pyroxentte \& 150-200 to core. 403.5-408 Pyroxentte, flne to coarse, av. 14\% magnet1te; cut by a few felsic bands; coarse phase (1) 405' with patches of chlorite containing limonite pseudomorphs after pyrite. 408-413 Gabbro, med. to coarse, av. $50 \%$ felsics; highly sheared (random).

413-416 Gabbro, med., av. $10 \%-15 \%$ felsics.

416-419 Gabbro, coarse (av. 5m.), ar. $35 \%$ fela1cs \& 5\% magnetite; $3^{\prime \prime}$ fels1c band (c) 418 (3) $30^{\circ}$. to core; fractures av. $40^{\circ}$ to $60^{\circ}$ to core.

419-430 Gabbro to pyroxentte, med. to coarse, av. 5-15\% felsics \& 6\% magnetite; 8" felsic patch \& 423'-423.5; chloritized shears (s) $45^{\circ}$ to core.

430-446.5 Gabbro, med. to coarse (some crystals as large as $15 \mathrm{m.}$ ), av. $30 \%-60 \%$ felsics \& $6 \%$ magnetite; talcose shears @ $437.5^{\prime}-438.5^{\prime}$ @ $10^{\circ}-30^{\circ}$ to core; miaroIitic cavities (c) $444^{\prime}$ are lined by euhedral plagioclase laths.

Page $95 / 189$

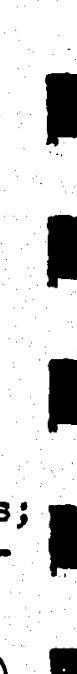


DRILU HOLE H-8

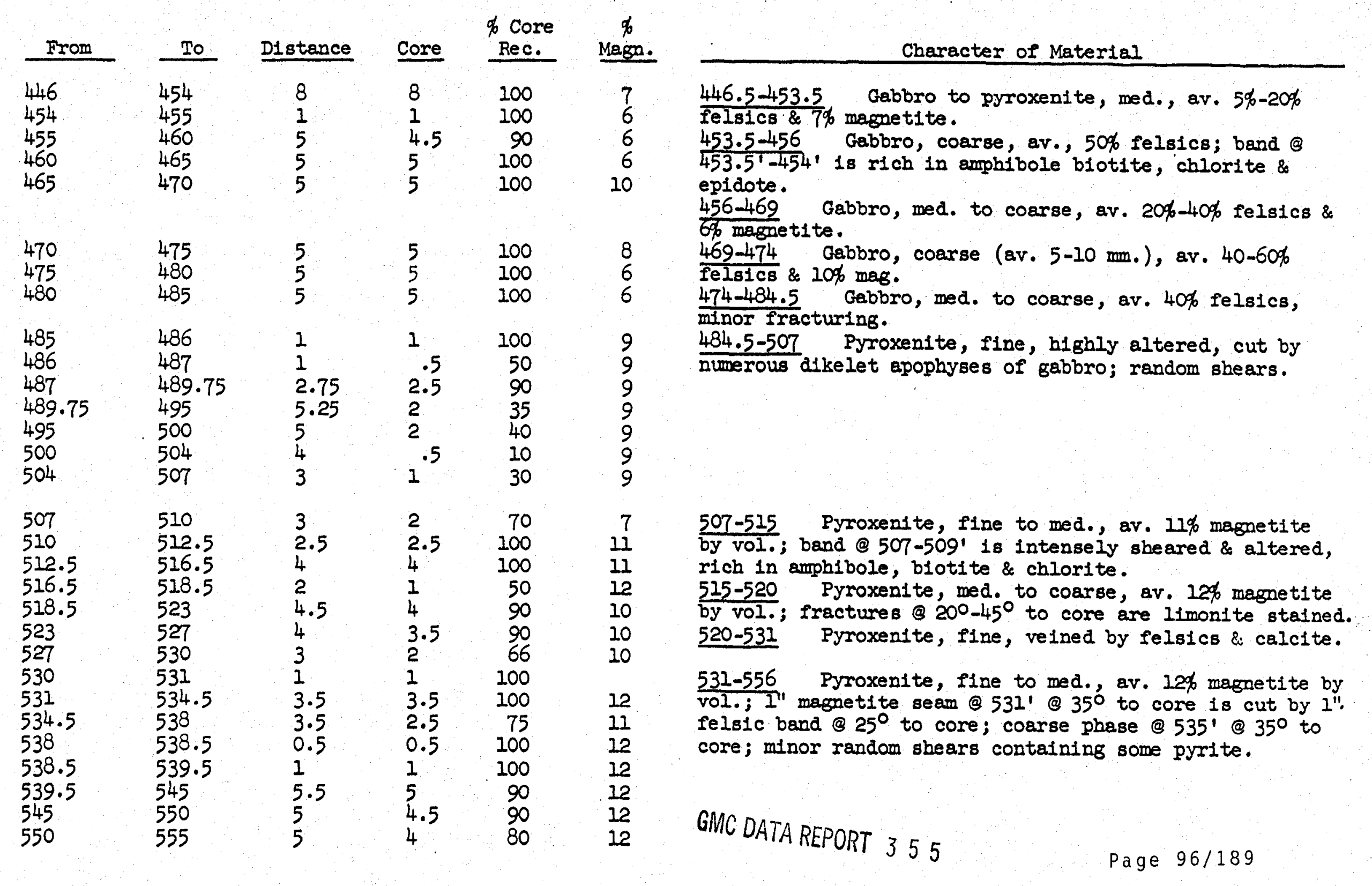


DRILI HOLE H-8

\begin{tabular}{|c|c|c|c|c|}
\hline From & To & Distance & Core & Rec. \\
\hline $\begin{array}{l}555 \\
557 \\
559\end{array}$ & $\begin{array}{l}557 \\
559 \\
566\end{array}$ & $\begin{array}{l}2 \\
2 \\
7\end{array}$ & $\begin{array}{l}2 \\
1 \\
6\end{array}$ & $\begin{array}{r}100 \\
50 \\
90\end{array}$ \\
\hline $\begin{array}{l}566 \\
569 \\
572.5\end{array}$ & $\begin{array}{l}569 \\
572.5 \\
576.5\end{array}$ & $\frac{3}{4} \cdot 5$ & $\begin{array}{l}3 \\
3.5 \\
3.5\end{array}$ & $\begin{array}{r}100 \\
100 \\
90\end{array}$ \\
\hline
\end{tabular}

Character of Material

556-557 Pyroxenite, coarse, ave. $16 \%$ magnetite. 557-559 Pyroxentte, fine, badly broken. 559-563 Pyroxentte, coarse, av. 15\% magnet1te; $2-3$ " band of magnetite (C) 561'.

563-576.5 Pyroxenite, fine, av. 13\% magnetite; shears and fractures rare, contain chlorite \& some pyrite; rare felsic velnlets \& 300 to core. 
Started: July 4, 1959

Completed: July 18, 1959

Elevation (collar reference $\mathrm{H}-2$ ) $=f 56$

Located $430^{\circ}$ due north of south-end center post of $19 \mathrm{~J}$

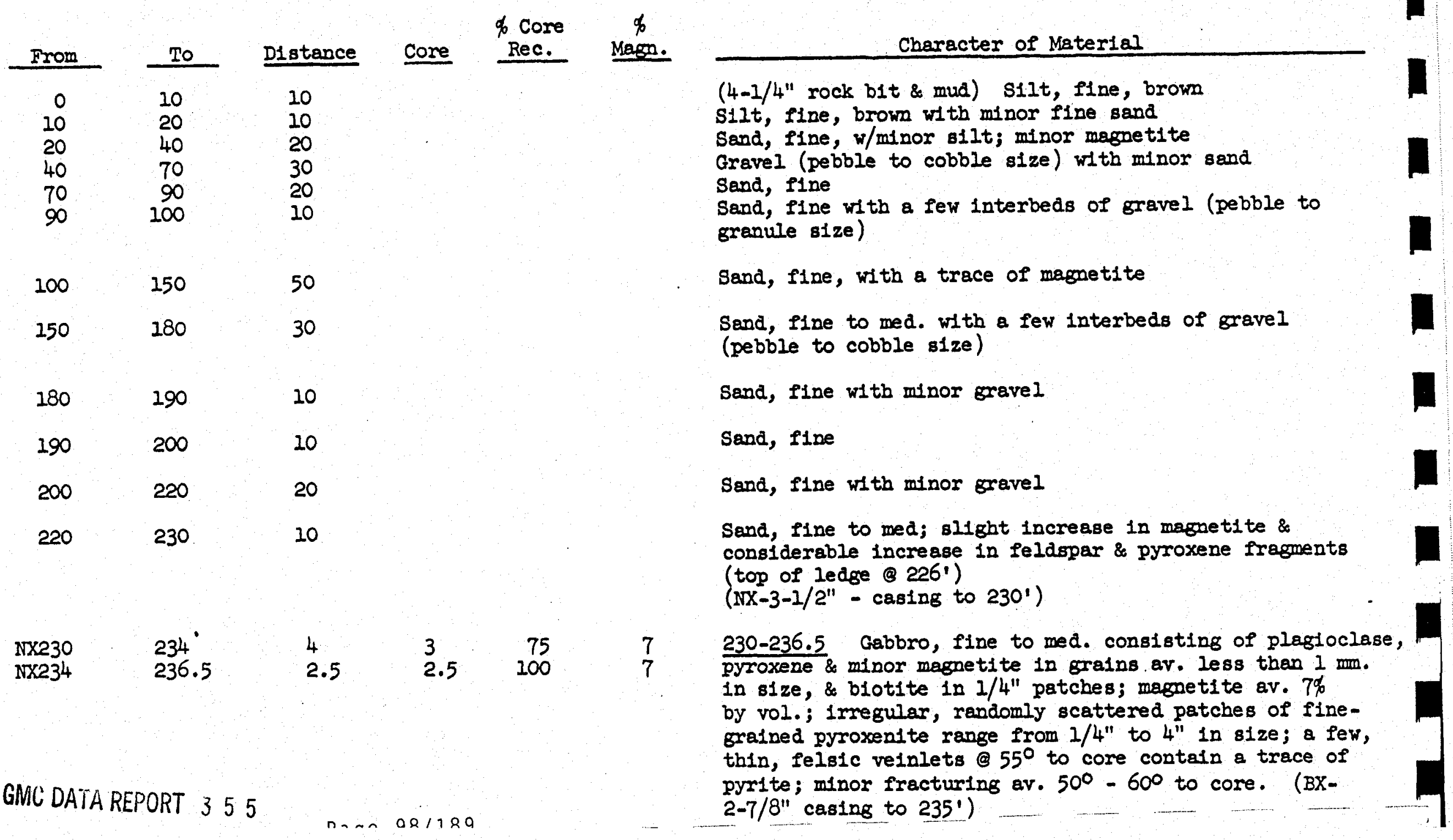


DRIIL BOLE H-9

\begin{tabular}{|c|c|c|c|c|c|}
\hline From & To & Distance & Core & $\begin{array}{c}\text { \% Core } \\
\text { Rec. }\end{array}$ & $\begin{array}{c}\phi \\
\text { Megn }\end{array}$ \\
\hline $\begin{array}{l}236.5 \\
240 \\
250 \\
260\end{array}$ & $\begin{array}{l}240 \\
250 \\
260 \\
262\end{array}$ & $\begin{array}{c}3.5 \\
10 \\
10 \\
2\end{array}$ & $\begin{array}{c}3.5 \\
10 \\
10 \\
2\end{array}$ & $\begin{array}{l}100 \\
100 \\
100 \\
100\end{array}$ & $\begin{array}{l}7 \\
7 \\
7 \\
7\end{array}$ \\
\hline 262 & 267 & 5 & 5 & 100 & 9 \\
\hline $\begin{array}{l}267 \\
268.5 \\
273\end{array}$ & $\begin{array}{l}268.5 \\
273 \\
276.5\end{array}$ & $\begin{array}{l}1.5 \\
4.5 \\
3.5\end{array}$ & $\begin{array}{l}1.5 \\
4.5 \\
2.5\end{array}$ & $\begin{array}{r}100 \\
100 \\
70\end{array}$ & $\begin{array}{l}7 \\
7 \\
8\end{array}$ \\
\hline $\begin{array}{l}276.5 \\
279\end{array}$ & $\begin{array}{l}279 \\
281\end{array}$ & $\begin{array}{l}2.5 \\
2\end{array}$ & $\begin{array}{l}2.5 \\
1.5\end{array}$ & $\begin{array}{r}100 \\
75\end{array}$ & $\begin{array}{l}8 \\
8\end{array}$ \\
\hline $\begin{array}{l}281 \\
284\end{array}$ & $\begin{array}{l}284 \\
286.5\end{array}$ & $\begin{array}{l}3 \\
2.5\end{array}$ & $\begin{array}{l}3 \\
2.5\end{array}$ & $\begin{array}{l}100 \\
100\end{array}$ & $\begin{array}{l}7 \\
7\end{array}$ \\
\hline 286.5 & 288 & 1.5 & 1.5 & 100 & 10 \\
\hline $\begin{array}{l}288 \\
292\end{array}$ & $\begin{array}{l}292 \\
299\end{array}$ & $\begin{array}{l}4 \\
7\end{array}$ & $\begin{array}{l}4 \\
6\end{array}$ & $\begin{array}{r}100 \\
90\end{array}$ & $\begin{array}{l}7 \\
7\end{array}$ \\
\hline 299 & 304 & 5 & 5 & 100 & 8 \\
\hline
\end{tabular}

\section{Character of Material}

236.5-262.5 Gabbro, IIne to med. like above, relatively unfractured; av. 7\% magnetite by vol.; pyrite along fractures; I" amphibole andesite dikelet (a) 237' \& $30^{\circ}$ to core; rare l" patches of pyrox.; a few felsic velnlets $\left(1 / 2^{\prime \prime}\right)$ \& 400 to core.

262.5-265 Pyrox., fine; very Irregular contact with the diorite, little evidence of elther contact chililing or alteration; probably xenolithic; pyrox. is cut by numerous thin carbonate-zeolite-pyrite veinlets \& ave. several l" pore; av. Ilo magnetite by vol.; includes Beveral 1" patches of magnetite.

265-271 Gabbro, med., with scattered patches of pyrox., $1 / 4^{\prime \prime}$ felsic velnlets av. $30^{\circ}-50^{\circ}$ to core.

271-274 Andesite to trachyandesite, light gray, dike cutting gabbro \& $15^{\circ}-20^{\circ}$.

$274-281.5$ Gabbro, flne to med., saturated by Irregular patches of pyrox.; intensely fractured from $278.5^{\prime}-281.5^{\prime}$ (9) $0^{\circ}-10^{\circ}$ \& $40^{\circ}-50^{\circ}$ to core; some $1 / 4^{\prime \prime}-1 / 2^{\prime \prime}$ amphibole phenocrysts in the gabbro; a few felsic veinlets (3) $30^{\circ}$ to core; rock av. $8 \%$ magnetite.

281.5-286.5 Gabbro, fine, like above, but with few patches of pyrox.

286.5-288 Andesite or very fine-grained pyroxente, med. graylsh-green; cuts gabbro \& $60^{\circ}$ to core.

288-299 Gabbro, P1ne, relative $2 y$ unfractured; av. $7 \%$ magnetite by vol.; I" felsic-amphibole veinlet (a) 289.5 (a) $40^{\circ}$ to core; pyrite along fractures.

299-300.5 Pyrox. fine; amphibole in patches \& veinlets, 
DRILL HOLE H-9

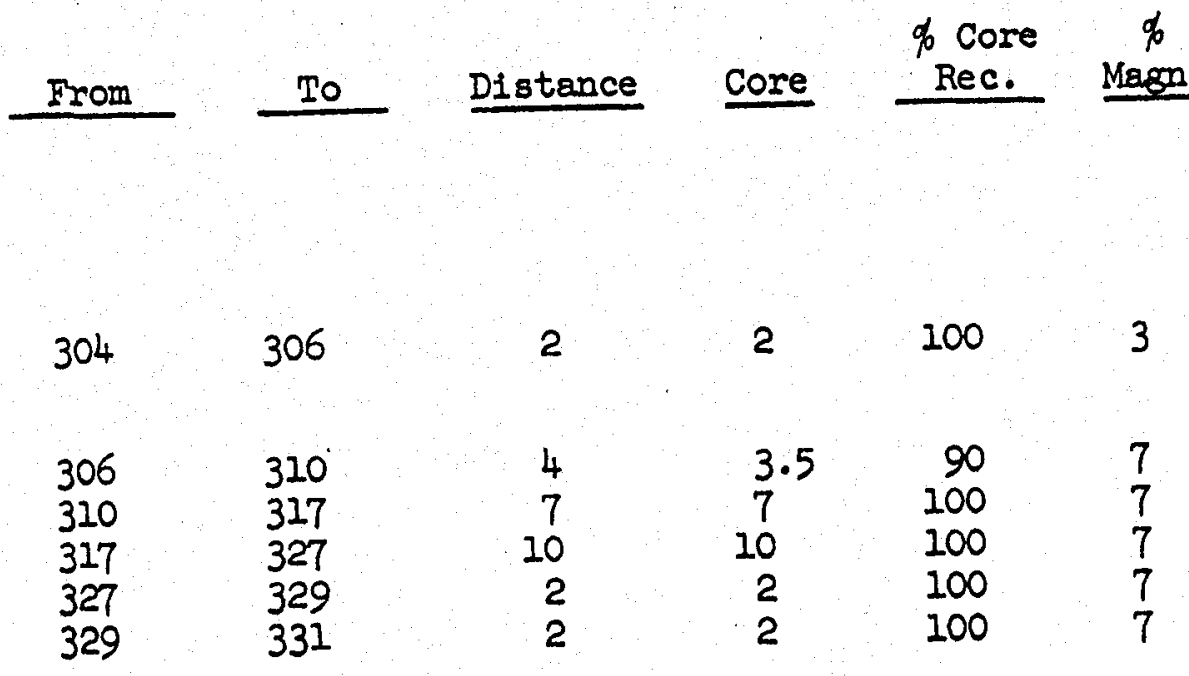

$\begin{array}{llcccc}331 & 333.5 & 2.5 & 2 & 80 & 7 \\ 333.5 & 336 & 2.5 & 0.5 & 20 & 7 \\ 336 & 340 & 4 & 3 & 75 & 7 \\ 340 & 340.5 & 0.5 & 0.5 & 100 & 7 \\ 340.5 & 350.5 & 10 & 10 & 100 & 8\end{array}$

$\begin{array}{lllll}350.5 & 356.5 & 6 & 6 & 100 \\ 356.5 & 361 & 4.5 & 4.5 & 100 \\ 361 & 364.5 & 3.5 & 3.5 & 100 \\ 364.5 & 369 & 4.5 & 4.5 & 100\end{array}$

7
7
7
8

300.5-301.5 Fels1c d1kelet; nearly solid feldspar in large crystals ( $1 "$ - 2"); cuts core @ $30^{\circ}-40^{\circ}$. 301.5-303 Gabbro, f1ne to med., like above; with disseminated pyrite.

303-305 Felsic dikelet highly fractured \& altered with considerable carbonate contalning $1 / 4$ " pseudomorph after

pyrite. $305-331.5$ Gabbro, fine to med., with a few minor zones of fracturing; pyrite along fractures \& disseminated;

av. $7 \%$ magnetite by vol; scattered $1 / 4 "-1 "$ felsic vinlets cut core \& $0^{\circ}-200^{\circ}$; felsic zones \& $309^{\prime} \& 327^{\prime}$ are bighly fractured \& mineralized by carbonate, chlorite \& limonite (pseudos, after pyrite); miarolitic cavity ( $323.5^{\prime}$ contalns euhedral crystals of pyrite, epldote, calcite \& barite (?); deuteric to hydrothermal alteration of the main gabbro (sericitization \& saussuritization (?) of the plaffoclase) along thin, scattered stringers which av. $50^{\circ}-70^{\circ}$ to core.

331.5-338 Gabbro, fine, w1th intense fracturing \& minor shearing (c) av, of $60^{\circ}-80^{\circ}$ to core; veinlets of carbonate \& considerable pyrite.

338-347.5 Gabbro, fine to med. relatively unfractired; av. 7\% magnetite; considerable pyrite.

347.5-349.5 Pyrox., fine to med., with patches of amphibole \& felsics, cut by $2^{\prime \prime}$ dikelet of andesite of very fine pyrox. () 200 to core; irregular contact with gabbro.

349.5-368.5 Grbbro, fine to med., relatively unfractured; av. $7 \%$ magnetite; pyrite along fractures; with a few irregular patches of pyrox.; sheared \& altered zone (3) $56.5^{\prime} ; 1 / 4^{\prime \prime}$ to $1^{\prime \prime}$ felsic veinlets av. 200400 to core; $3^{\prime \prime}$ trachyandesite dikelet (3) 365.5 (s) $60^{\circ}$ to core.

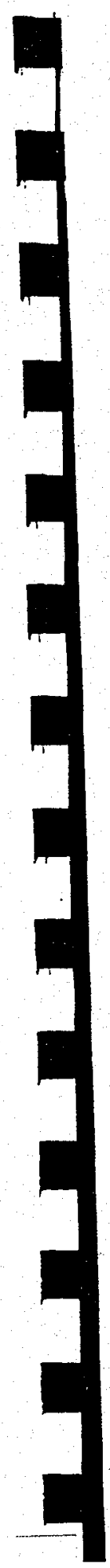


DRTLC HOLE $E-9$

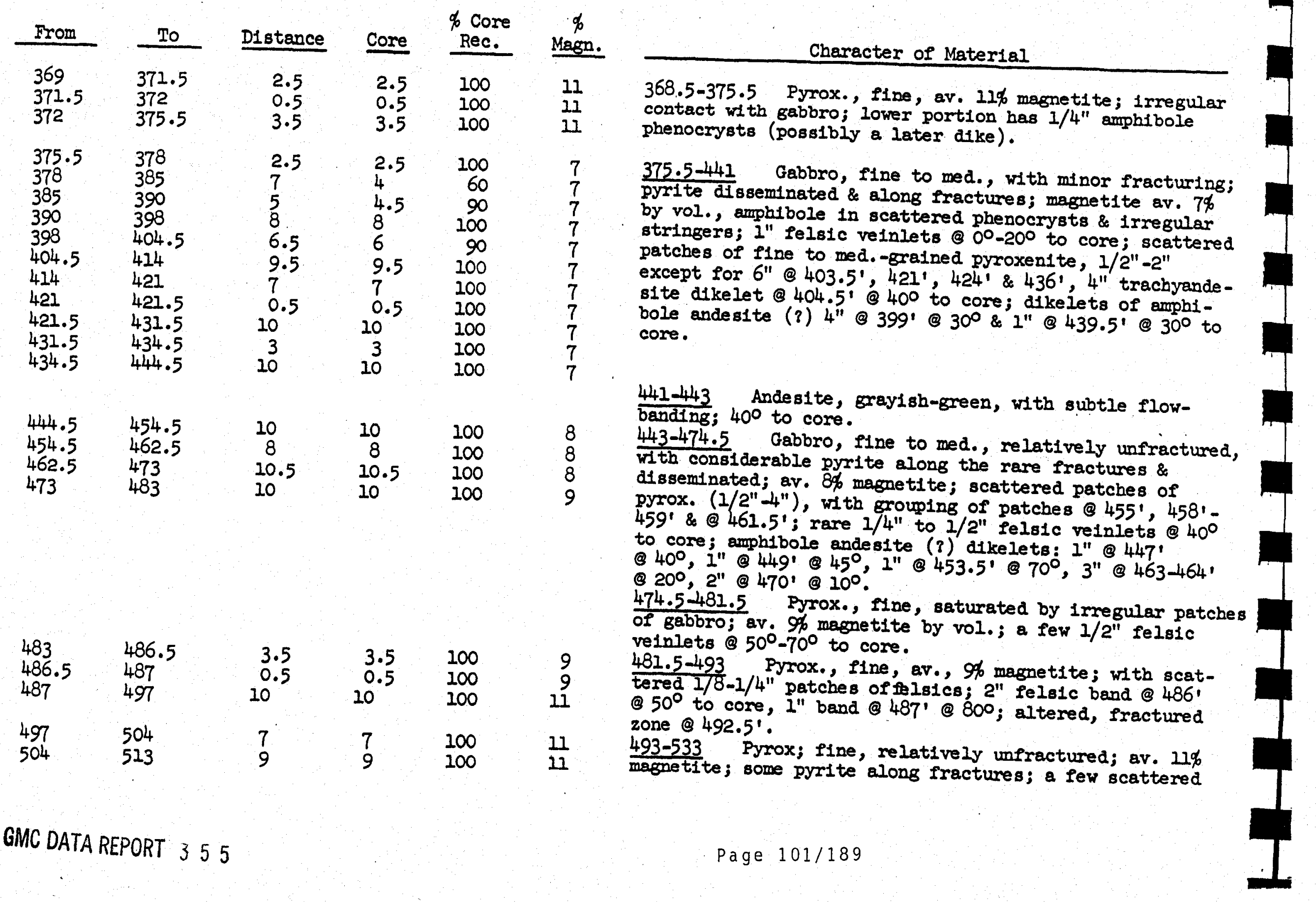


DRILU BOLE H-9

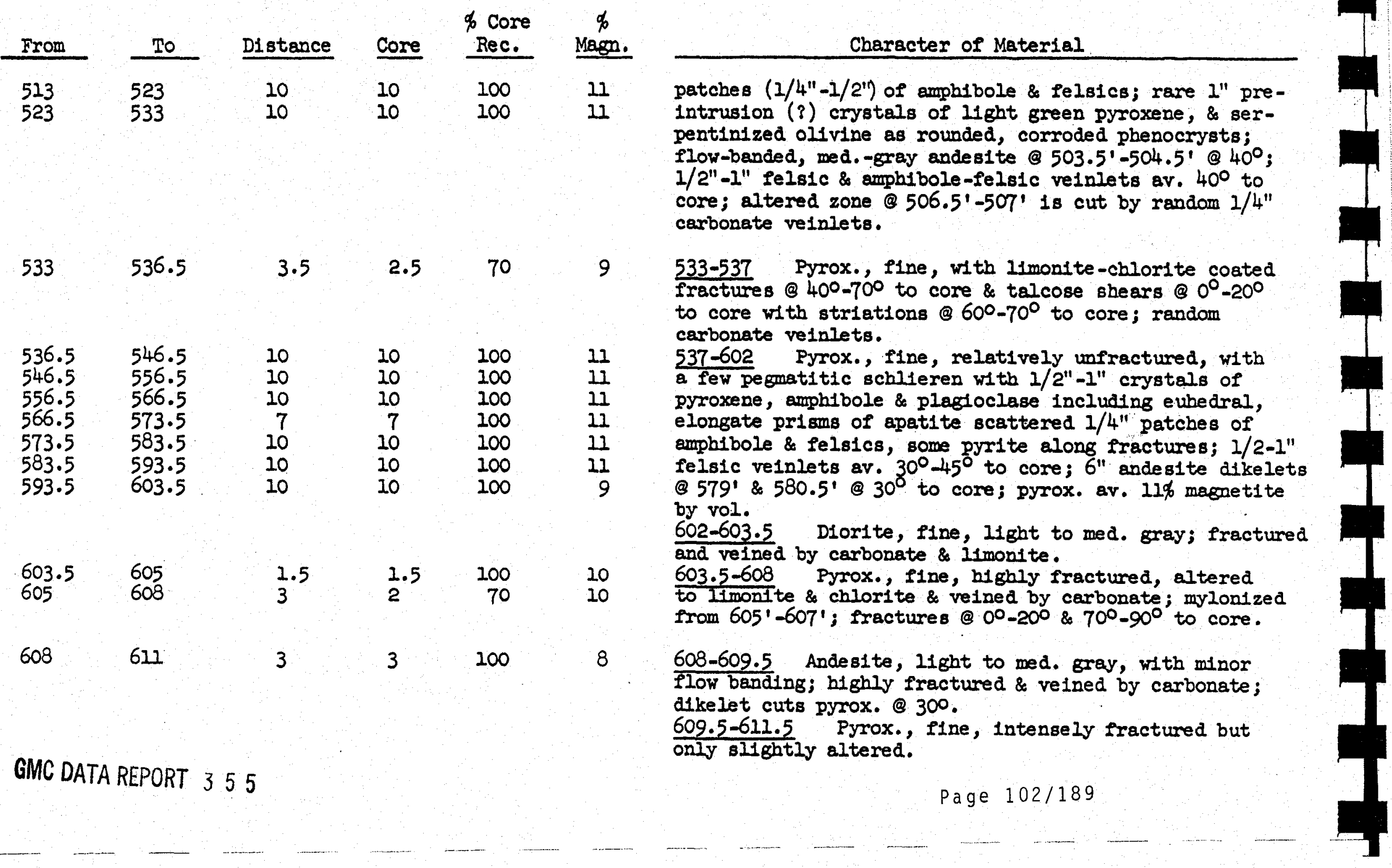


DRILL HOLE H-9

$\begin{array}{llcccc}\text { From } & \text { To } & \text { Distance } & \text { Core } & \text { \% Core } & \text { Rec } \\ 611 & 621 & 10 & 10 & 100 & 11 \\ 621 & 630 & 9 & 9 & 100 & 10\end{array}$

Character of Material

611.5-628 Pyrox., fine, av. 11\% magnetite by vol. a few minor zones of alteration \& shearing (@ 600-80 to core); 6" I1ght-gray andesite dikelet (a) 614.5' () $80^{\circ}$ to core; trace of pyxite along fractures.

628-630 Pyrox., fine, fractured sheared \& altered, cut by several $1^{\prime \prime}$ andesite dikelets (\&) $30^{\circ}-40^{\circ}$ to core \& several, thin carbonate veinlets; shears (a) $20^{\circ}-40^{\circ}$ to core.

$\begin{array}{llllll}630 & 631 & 1 & 1 & 100 & 7 \\ 631 & 636 & 5 & 5 & 100 & 10 \\ & & & & & \\ 636 & 640 & 4 & 4 & 100 & 8 \\ 640 & 650 & 10 & 10 & 100 & 9 \\ & & & & & \\ 650 & 660 & 10 & 10 & 100 & 10 \\ 660 & 670 & 10 & 10 & 100 & 10\end{array}$

670

680

10

10

100

10

630-631.5 Andesite, Ifght gray, w1t h flow banding, somewhat fractured \& altered; cuts core (a) $30^{\circ}$.

631.5-636.5 Pyrox., fine, cut by $1 / 2^{\prime \prime}$ to $I^{\prime \prime}$ velnlets of felsics (s) av. of $30^{\circ}$ to core \& by several veinlets of carbonate; one $1 / 2^{\prime \prime}$ blotite-felsic veinlet (c) $30^{\circ}$.

636.5-638 Andesite, I1ke 630'-631.5', sheared @ $30^{\circ}$ to core w1 th striations (1) $90^{\circ}$

638-650 Pyrox., fine with moderate fracturing @ 40 $60^{\circ}$ to core; zone of shearing \& alteration @ 641.5';
av. $9 \%$ magnetite.

650-670 Pyrox., fine, relatively unfractured, with Irregular patches of coarse-grained pyrox. (a) 660' \& (? $663.5 '-664.5^{\prime}$; scattered patches of amphibole but felsics rare; $1^{\prime \prime}$ dikelet of amphibole andesite (a) $666.5^{\prime}-667^{\prime}$ (a) 100 to core cut by I" dikelet of Ilght gray andesite to trachyandesite (\& $667-668$ ' \& $60^{\circ}$ to core; av. $10 \%$
magnetite.

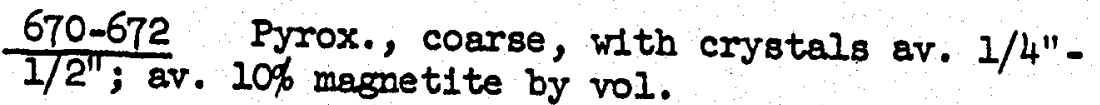


DRILL HOLE H-9

\begin{tabular}{|c|c|c|c|c|c|c|}
\hline From & To & D1stance & Core & $\begin{array}{l}\text { \% Core } \\
\text { Rec. }\end{array}$ & $\begin{array}{c}\% \\
\text { Magn. }\end{array}$ & Character of Material \\
\hline $\begin{array}{l}680 \\
687 \\
697\end{array}$ & $\begin{array}{l}687 \\
697 \\
707\end{array}$ & $\begin{array}{r}7 \\
10 \\
10\end{array}$ & $\begin{array}{r}7 \\
10 \\
10\end{array}$ & $\begin{array}{l}100 \\
100 \\
100\end{array}$ & $\begin{array}{l}9 \\
9 \\
9\end{array}$ & 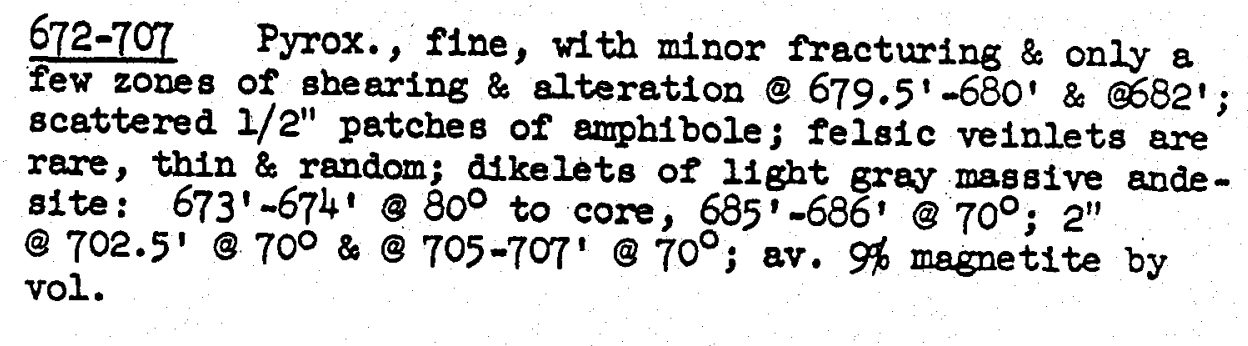 \\
\hline 707 & 715 & 8 & 7 & 90 & 9 & $\frac{707-713}{\text { fractures \& a few carbonate veinlets. }}$ \\
\hline 727.5 & 715.5 & 2.5 & 2.5 & 100 & 8 & 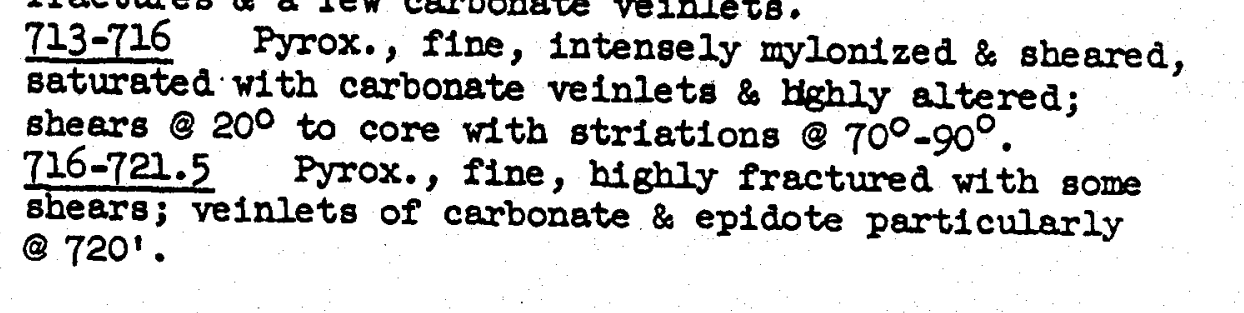 \\
\hline 721.5 & 728 & 6.5 & 6.5 & 100 & 8 & 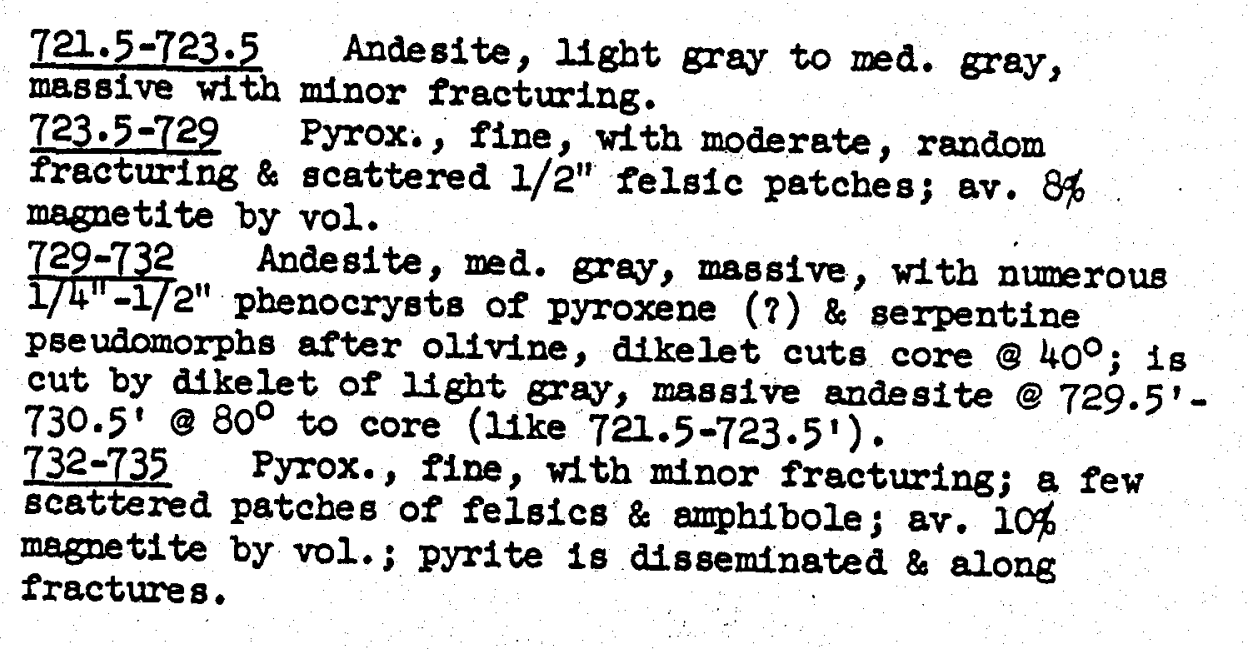 \\
\hline ZMC DAT & ORT 3 & & & & & \\
\hline & & & & & & Page $104 / 189$ \\
\hline
\end{tabular}


DRILC HOLE H-9

\begin{tabular}{|c|c|c|c|c|c|c|}
\hline From & To & Distance & Core & $\begin{array}{c}\text { \% Core } \\
\text { Rec. }\end{array}$ & $\begin{array}{c}\% \\
\text { Magn. }\end{array}$ & Character of Material \\
\hline $\begin{array}{l}738 \\
748 \\
755 \\
760.5\end{array}$ & $\begin{array}{l}748 \\
755 \\
760.5 \\
770.5\end{array}$ & $\begin{array}{l}10 \\
7 \\
10\end{array}$ & $\begin{array}{l}10 \\
7 \\
5 \cdot 5 \\
10\end{array}$ & $\begin{array}{l}100 \\
100 \\
100 \\
100\end{array}$ & $\frac{11}{11}$ & 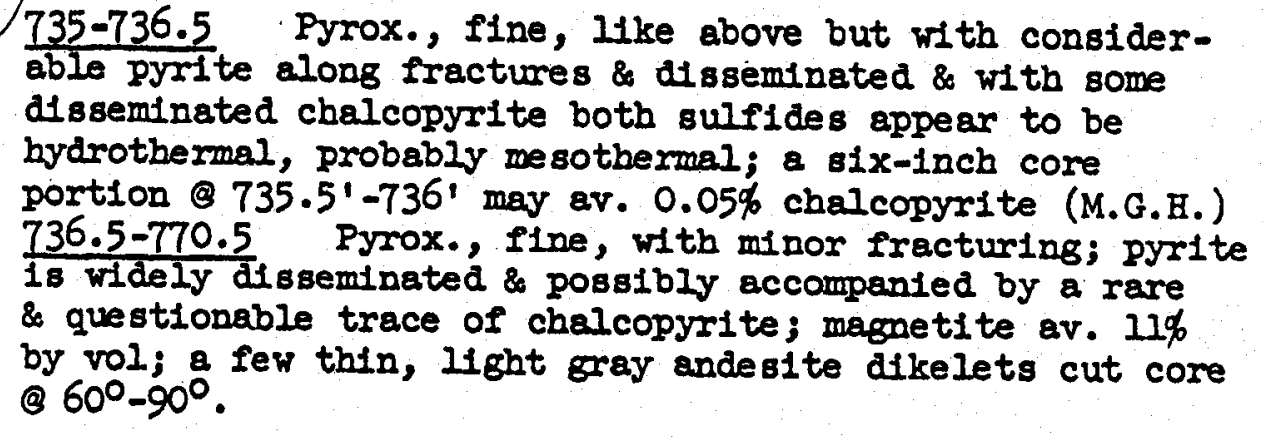 \\
\hline 770.5 & 773.5 & 3 & 3 & 100 & 7 & 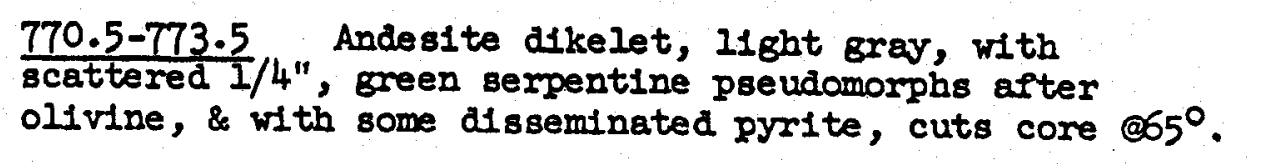 \\
\hline $\begin{array}{l}773.5 \\
778.5 \\
780.5 \\
786.5 \\
794 \\
802\end{array}$ & $\begin{array}{l}778.5 \\
780.5 \\
786.5 \\
794 \\
802 \\
812\end{array}$ & $\begin{array}{l}5 \\
2 \\
6 \\
7.6 \\
8 \\
10\end{array}$ & $\begin{array}{l}5 \\
2 \\
6 \\
7.5 \\
8 \\
10\end{array}$ & $\begin{array}{l}100 \\
100 \\
100 \\
100 \\
100 \\
100\end{array}$ & $\begin{array}{r}10 \\
10 \\
10 \\
10 \\
10 \\
9\end{array}$ & 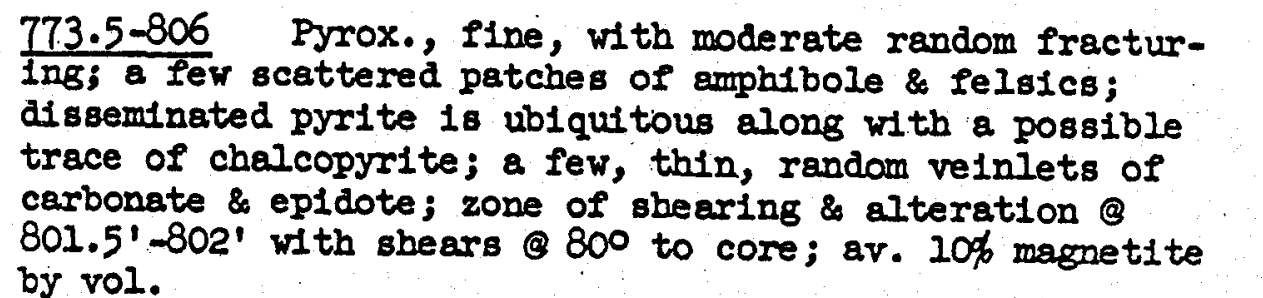 \\
\hline 812 & 822 & 10 & 10 & 100 & 9 & $\begin{array}{l}\text { 806-817 Pyrox, fine, with considerable felsics in } \\
\text { 1 m. patches; slightly sheared \& altered; numerous } \\
\text { thin veinlets of carbonate \& epldote } @ 00-10^{\circ} \text { \& } 600-90^{\circ} \\
\text { to core; disseminated pyrite; a few altered dikelets of } \\
\text { andesite. } \\
817-822 \\
\text { by random velniets of chlorite, with fewer velnlets of } \\
\text { carbonate \& epldote; flnely disseminated pyrite. }\end{array}$ \\
\hline $\begin{array}{l}822 \\
832\end{array}$ & $\begin{array}{l}832 \\
841\end{array}$ & $\begin{array}{r}10 \\
9\end{array}$ & $\begin{array}{r}10 \\
8\end{array}$ & $\begin{array}{r}100 \\
90\end{array}$ & $\begin{array}{l}9 \\
8\end{array}$ & $\begin{array}{l}\frac{822-837.5}{\text { Pyrox., med. to coarse like above but less }} \\
\text { magnetite. }\end{array}$ \\
\hline GMC & IEPOR & 55 & & & & page \\
\hline
\end{tabular}




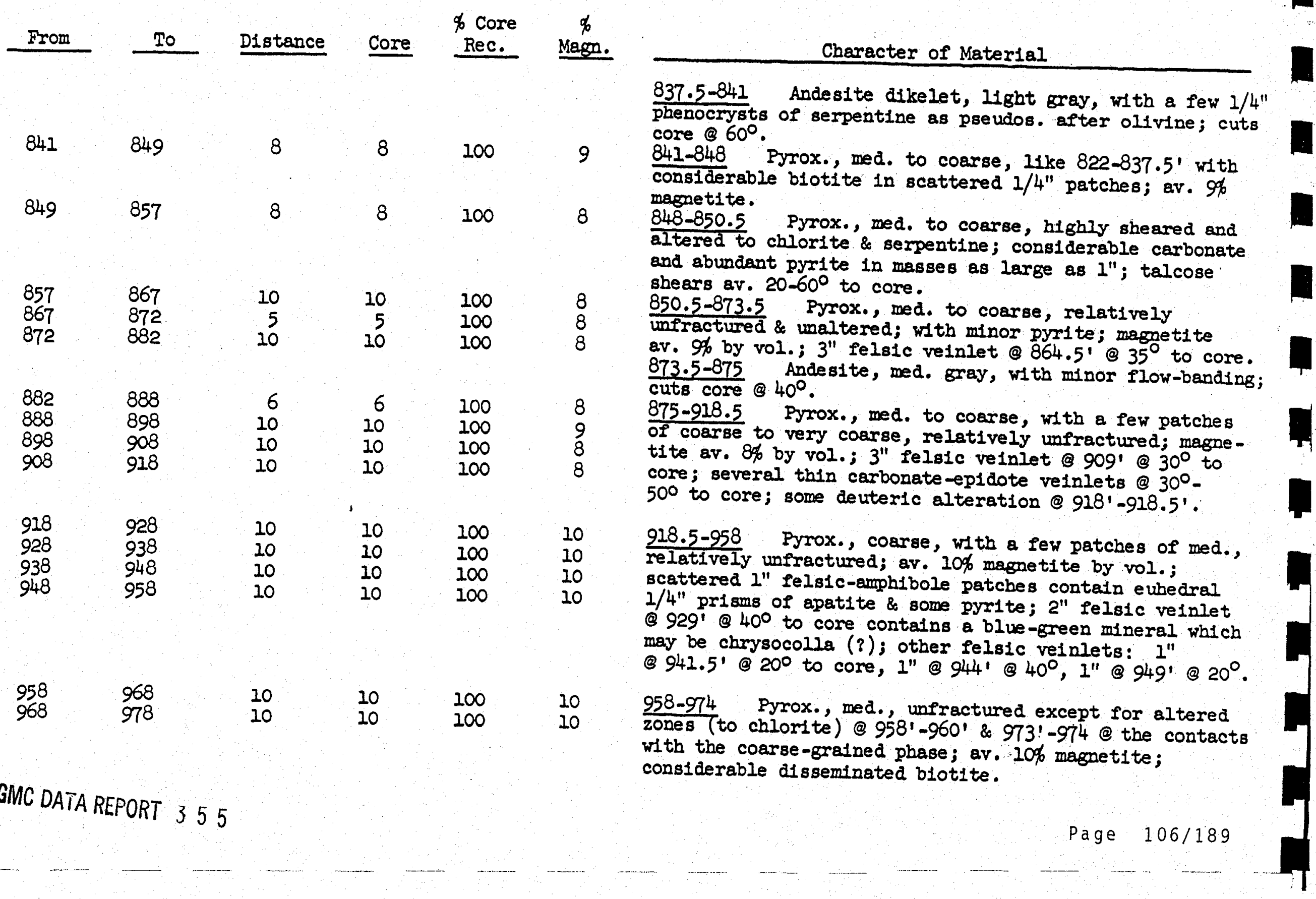


DRILL HOLE H-9

\begin{tabular}{ccccccc} 
From & To & Distance & Core & $\begin{array}{c}\text { \% Core } \\
\text { Rec. }\end{array}$ & $\begin{array}{c}\% \\
\text { Mrgn. }\end{array}$ \\
\cline { 3 - 5 } & 988 & 10 & 10 & 100 & 9 \\
988 & 994 & 6 & 6 & 100 & 9 \\
994 & 1004 & 10 & 10 & 100 & 9 \\
1004 & 1014 & 10 & 10 & 100 & 9 \\
1014 & 1024 & 10 & 10 & 100 & 9 \\
1024 & 1034 & 10 & 9 & 90 & 7
\end{tabular}

$\begin{array}{llccc}1034 & 1044 & 10 & 10 & 100 \\ & & & & \\ 1044 & 1049 & 5 & 4 & 80 \\ 1049 & 1059 & 10 & 10 & 100 \\ 1059 & 1066.5 & 7.5 & 7.5 & 100 \\ 1066.5 & 1076.5 & 10 & 10 & 100 \\ 1076.5 & 1083.5 & 7 & 7 & 100 \\ 1083.5 & 1093.5 & 10 & 10 & 100\end{array}$

$\begin{array}{ll}1093.5 & 1103.5 \\ 1103.5 & 1113.5 \\ 1113.5 & 1123.5 \\ 1123.5 & 1133.5 \\ 1133.5 & 1142.5 \\ 1142.5 & 1146.5 \\ 1146.5 & 1152.5\end{array}$

$\begin{array}{rrrr}10 & 10 & 100 & 10 \\ 10 & 10 & 100 & 10 \\ 10 & 10 & 100 & 10 \\ 10 & 10 & 100 & 11 \\ 9 & 9 & 100 & 11 \\ 4 & 4 & 100 & 11 \\ 6 & 6 & 100 & 11\end{array}$

\section{9}

9

9

9

GMC DATA REPORT 355

\section{Character of Material}

974-989 Pyrox., coarse, relative 1 y unfractured; av. 9\% magnetite by vol.; Iike 918.5'-958'.

989-1029 Pyrox., med to coarse, relatively unfractured dikelets: med. 992.5' @ 400 to core, 4l" -banded andesite @ 991.5'Q1014' @ 10 -200, $2 "$ " amphtbole andesite dikelet (3) $20^{\circ}$.

1029-1031.5 Andesite, med. grav, moderately 1031.5-1034.5 Adesite, med. gray, moderately fractured. mylonized \& altered, cut by nume, Intensely sheared, veinlets.

$\frac{1034.5-1040}{\text { av. of } 30^{0}-60^{\circ}}$ to cyrox., coarse, unmylonized but sheared av. of $30^{\circ}-60^{\circ}$ to core; zone from 1038-1039.5' is saturated 1040-1079.5 Pyrox \& a few epidote-carbonate veinlets. relatively unfractured except, with a few med. patches; 1058.5', \& 1066'-1067' except for zones (3) 1045.5', $1 / 2^{\prime \prime}-1 "$ felsic rein $1079.5-1093$ velnlets av. 400 to core.

to core 1093 Pyrox., med., moderately sheared @ $0^{\circ}-200$ saturated by veinlets of $20^{\circ}-30^{\circ}$ to core; several zones no visible pyrite.

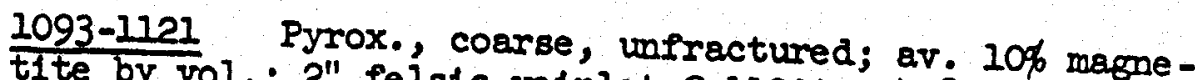
tite by vol.; 2" felsic velnlet @ 1120' @ $40^{\circ}$ to core. $\frac{1121-1153.5}{\text { pyrox. Pyrox., med., w1th a few zones of coarse }}$ pyrox. \& a few ragged groupings of magnetite granules; site dikelet @ $1148-1148.5$ ' @ $40^{\circ}$ to core. 
DRITC HOLE H-9

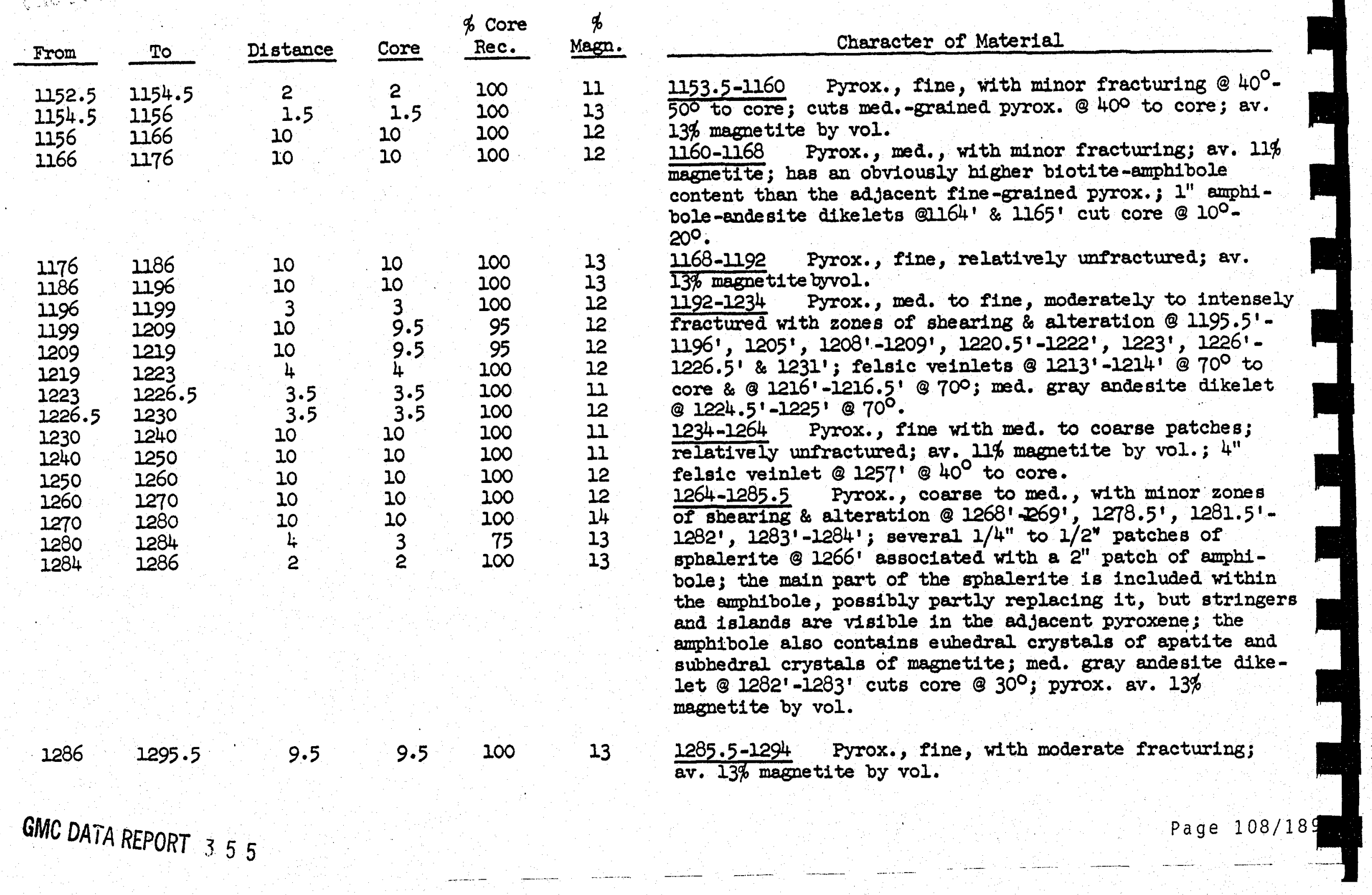


RILL HOLE H-9

\begin{tabular}{|c|c|c|c|c|c|}
\hline From & To & Distance & Core & $\begin{array}{c}\text { \% Core } \\
\text { Rec. }\end{array}$ & $\begin{array}{c}\% \\
\text { Magn }\end{array}$ \\
\hline $\begin{array}{l}1295.5 \\
1296.5 \\
1299 \\
1301.5 \\
1305\end{array}$ & $\begin{array}{l}1296.5 \\
1299 \\
1301.5 \\
1305 \\
1315\end{array}$ & $\begin{array}{c}1 \\
2.5 \\
2.5 \\
3.5 \\
10\end{array}$ & $\begin{array}{l}1 \\
1 \\
1 \\
2.5 \\
7.5\end{array}$ & $\begin{array}{r}100 \\
40 \\
40 \\
75 \\
75\end{array}$ & $\begin{array}{l}11 \\
10 \\
11 \\
11 \\
11\end{array}$ \\
\hline $\begin{array}{l}1315 \\
1317.5\end{array}$ & $\begin{array}{l}1317 \cdot 5 \\
1327 \cdot 5\end{array}$ & $10^{2.5}$ & $\begin{array}{l}2.5 \\
10^{-5}\end{array}$ & $\begin{array}{l}100 \\
100\end{array}$ & $\begin{array}{l}10 \\
12\end{array}$ \\
\hline $\begin{array}{l}1327.5 \\
1334.5 \\
1343 \\
1353 \\
1363 \\
1373 \\
1380 \\
1383\end{array}$ & $\begin{array}{l}1334.5 \\
1343 \\
1353 \\
1363 \\
1373 \\
1380 \\
1383 \\
1393\end{array}$ & $\begin{array}{c}7 \\
8.5 \\
10 \\
10 \\
10 \\
7 \\
3 \\
10\end{array}$ & $\begin{array}{c}7 \\
8.5 \\
10 \\
10 \\
10 \\
6 \\
3 \\
10\end{array}$ & $\begin{array}{r}100 \\
100 \\
100 \\
100 \\
100 \\
90 \\
100 \\
100\end{array}$ & $\begin{array}{l}12 \\
12 \\
12 \\
12 \\
14 \\
25 \\
15 \\
14\end{array}$ \\
\hline
\end{tabular}

$\begin{array}{ll}1403 & 10 \\ 1414 & 11 \\ 1424 & 10 \\ 1430 & 6 \\ 1435 & 5 \\ 1436.5 & 1.5 \\ 1445.5 & 9\end{array}$

$\begin{array}{ccc}3.5 & 35 & 11 \\ 11 & 100 & 12 \\ 10 & 100 & 12 \\ 6 & 100 & 12 \\ 5 & 100 & 12 \\ 1.5 & 100 & 12 \\ 9 & 100 & 12\end{array}$

Character of Materfal

1294-1308 Pyrox., fine, highly sheared \& altered; cut by several dikelets of altered, flow-banded andesite; shears (c) 100-30 to core; numerous thin veinlets of carbonate along with some epidote \& chlorite.

1308-1314 Pyrox., fine, relatively unfractured; av. 11\% magnetite by vol.; a few felsic veinlets (3) $25^{6}$ to core.

1314-1318 Pyrox., fine, moderately sheared \& altered; velned by epldote \& carbonate; shears \& $0^{\circ}-30^{\circ}$ with striations (a) $60^{\circ}-70^{\circ}$ to core.

1318-1370.5 Pyrox.; fine, with a few zones of minor shearing \& alteration; av. 12\% magnetite by vol.; rare $1 / 2^{\prime \prime}$ felalc velnlets av. $70^{\circ}$ to core; 4" dikelet of distinctly flow-banded andesite @ 1332'.

1370.5-1389.5 Pyrox., fine, with numerous masnetiteenriched zones; the magetite occurs in patchy to lensshaped grouplags of 1-2 mm., equant crystals which may be in part earlier than the associated pyroxene; magnetite -nalched zones \& 1370.5', 1372.5-1377.5', $1378.5^{\prime}, 1383^{\prime}, 1385.5^{\prime}, 1388$ '; med. gray, massive andesite in dikelet (8 $1380.5^{\prime}-1381.5^{\prime}$ \& $40^{\circ}$ to core; magnetite-enriched zones av. $32 \%$ magnetite by vol. \& $45 \%$ by wt.; normal pyrox. between enriched lens av. I1\% magnetite by vol.

1389.5-1407.5 Pyrox., med., relatively unfractured; av $12 \%$ magnetite by vol.; magnetite-enriched zone (3) 1407'. 1407.5-1493 Pyrox., fine, relatively unfractured except for zones of shearing \& slight alteration (i) $1417.5^{\prime}-1418^{\prime}, 1428.5-1432^{\prime}, 1435.5^{\prime}-1437,1445.5^{\prime}$, $1448.5^{\prime}-1450^{\prime}, 1453^{\prime}-1454^{\prime}, 1456^{\prime}, 1460.5^{\prime}, 1473.5^{\prime}$, $1480^{\prime}, 1483^{\prime}$, \& @ $1486^{\prime}$, shears av. $20^{\circ}-30^{\circ}$ to core; 
DRILL HOLE H-9

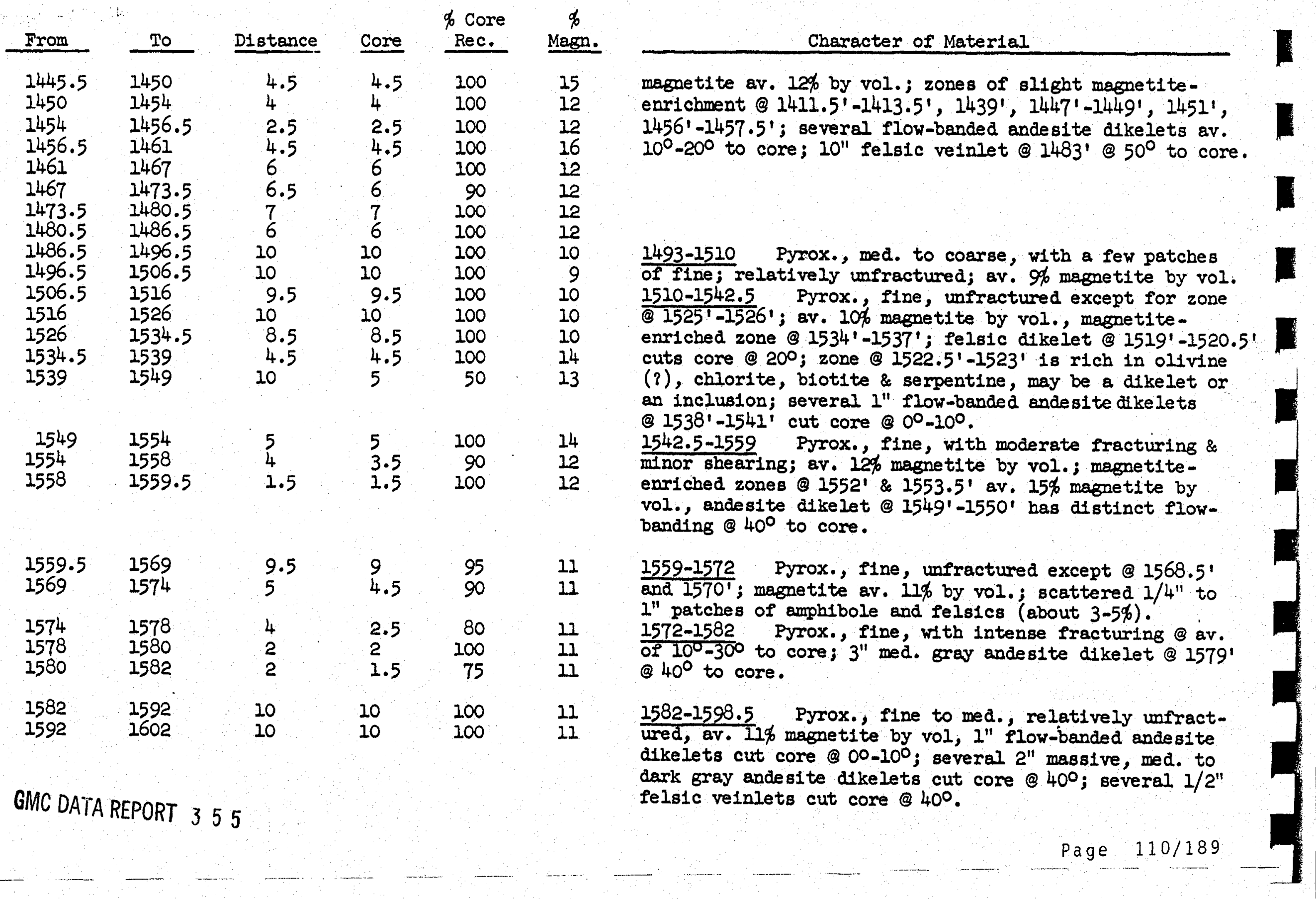




\begin{tabular}{|c|c|c|c|c|c|}
\hline From & To & Distance & Core & $\begin{array}{c}\text { of Core } \\
\text { Rec. }\end{array}$ & $\begin{array}{c}\% \\
\text { Magn }\end{array}$ \\
\hline $\begin{array}{l}1602 \\
1612 \\
1622\end{array}$ & $\begin{array}{l}1612 \\
1622 \\
1632\end{array}$ & $\begin{array}{l}10 \\
10 \\
10\end{array}$ & $\begin{array}{l}10 \\
10 \\
10\end{array}$ & $\begin{array}{l}100 \\
100 \\
100\end{array}$ & $\begin{array}{l}11 \\
11 \\
11\end{array}$ \\
\hline $\begin{array}{l}1632 \\
1636 \\
1638.5 \\
1642 \\
1645 \\
1653 \\
1661\end{array}$ & $\begin{array}{l}1636 \\
1638.5 \\
1642 \\
1645 \\
1653 \\
1661 \\
1671\end{array}$ & $\begin{array}{c}4 \\
2.5 \\
3.5 \\
3 \\
8 \\
8 \\
10\end{array}$ & $\begin{array}{l}4 \\
2.5 \\
3 \\
3 \\
8 \\
8 \\
10\end{array}$ & $\begin{array}{r}100 \\
100 \\
85 \\
100 \\
100 \\
100 \\
100\end{array}$ & $\begin{array}{l}12 \\
13 \\
13 \\
13 \\
13 \\
13 \\
11\end{array}$ \\
\hline
\end{tabular}

$\begin{array}{llllll}1671 & 1681 & 10 & 10 & 100 & 12 \\ 1681 & 1685 & 4 & 4 & 100 & 12 \\ 1685 & 1695 & 10 & 10 & 100 & 12 \\ 1695 & 1706 & 11 & 11 & 100 & 12 \\ 1706 & 1709 & 3 & 3 & 100 & 12 \\ & & & 3 & 100 & 12 \\ 1709 & 1712 & 3 & 3 & 100 & 12 \\ 1712 & 1715.5 & 3.5 & 3.5 & 100 & 11 \\ 1715.5 & 1719.5 & 4 & 4 & & \end{array}$

\section{Character of Material} $\frac{1598.5-1601.5}{\text { fractured. }}$ Pyrox., med.; Intensely randomly

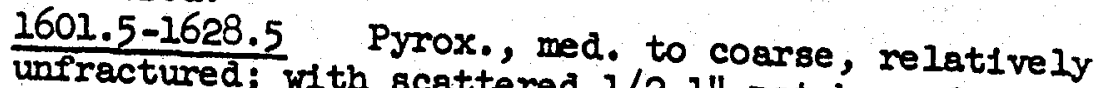
unf fectured; with scattered 1/2-1" patches of amphibole and felsics; a few $1 / 2^{\prime \prime}$ felsic velniets (8) $40^{\circ}$ to core; cut core (3) 30' cut core (3) $30^{\circ}$; pyrox., av. $11 \%$ magnetite by vol. w1th zone of enrichment (3) 1624.5'-1625.5'.

for zones of intense fracture, moderately fractured except $1636^{\prime}, 168^{\prime}-1638.5$, Iracturing and shearing (C) 1635'300 to core contain' $1642,1645^{\prime}, 1653.5^{\prime}$; shears (3) $10^{\circ}$. saturated contain some pyrite; zone @ $1658^{\prime}-1659.5^{\prime}$ is amphibole andesterinlets of carbonate; dikelets: (3) $1635.5^{\prime}$ ( ) $300^{\circ}$ t" (3) $1633.5^{\prime}-1634.5^{\prime}$ (a) $45^{\circ}$ to core; 4 " av. $13 \%^{\circ}$ magnet1te by $1638^{\prime}$ \& $10^{\circ}$, (c) 1646'-1647.5' \& $30^{\circ}$; magnetite enrichment. phenocrysts Pyrox., fine, to andesite with $1 / 4 "$ phenocrysts are rouetite-pyroxene intergrowth; the \& the magnetite is lar \& embayed by magmatic reaction der phase of the dite borthe dikelet cuts the pyrox. @ $30^{\circ}$ to amphibole andesite; 1666.5-1707 Pyrox pyrox. @ $30^{\circ}$ to core.

scattered I/4"-1" patches of with minor fracturing; pyrite along fractures; severol inole \& apatite; minor flow-bended andesite to sineral $1^{\prime \prime}$ dikelets of sinuously 12\% magnetite.

$\frac{1707-1734}{17}$ Pyrox., fine, with numerous zones of shearing but slight assoclated alteration; shears @ av. of $20^{\circ}$ to core; 6" med. gray, massive andesite dikelet 


\begin{tabular}{|c|c|c|c|c|c|}
\hline From & To & Distance & Core & $\begin{array}{c}\% \text { Core } \\
\text { Rec. }\end{array}$ & \\
\hline $\begin{array}{l}1719.5 \\
1721 \\
1726 \\
1729 \\
1731 \\
1741\end{array}$ & $\begin{array}{l}1721 \\
1726 \\
1729 \\
1731 \\
1741 \\
1751\end{array}$ & $\begin{array}{l}1.5 \\
5 \\
3 \\
2 \\
10 \\
10\end{array}$ & $\begin{array}{l}1.5 \\
2 \\
2 \\
1.5 \\
10 \\
10\end{array}$ & $\begin{array}{r}100 \\
40 \\
70 \\
75 \\
100 \\
100\end{array}$ & 1 \\
\hline 1751 & 1761 & 10 & 10 & 100 & 1 \\
\hline $\begin{array}{l}1761 \\
1766 \\
1769 \\
1772 \\
1773\end{array}$ & $\begin{array}{l}1766 \\
1769 \\
1772 \\
1773 \\
1783\end{array}$ & $\begin{array}{r}5 \\
3 \\
3 \\
1 \\
10\end{array}$ & $\begin{array}{l}5 \\
3 \\
2.5 \\
1 \\
10\end{array}$ & $\begin{array}{r}100 \\
100 \\
80 \\
100 \\
100\end{array}$ & $\begin{array}{l}12 \\
12 \\
12 \\
12\end{array}$ \\
\hline $\begin{array}{l}1783 \\
1785.5\end{array}$ & $\begin{array}{l}1785.5 \\
1788.5\end{array}$ & $\begin{array}{l}2.5 \\
3\end{array}$ & $\begin{array}{l}2 \\
3\end{array}$ & $\begin{array}{r}80 \\
100\end{array}$ & \\
\hline 1788.5 & 1799 & 10.5 & 10.5 & 100 & $\varepsilon$ \\
\hline 1799 & 1809 & 10 & 10 & 100 & 8 \\
\hline $\begin{array}{l}1809 \\
1819 \\
1827.5 \\
1833 \\
1843 \\
1853 \\
1863\end{array}$ & $\begin{array}{l}1819 \\
1827 \cdot 5 \\
1833 \\
1843 \\
1853 \\
1863 \\
1870\end{array}$ & $\begin{array}{l}10 \\
8.5 \\
5.5 \\
10 \\
10 \\
10 \\
7\end{array}$ & $\begin{array}{c}10 \\
8.5 \\
5.5 \\
10 \\
10 \\
10 \\
7\end{array}$ & $\begin{array}{l}100 \\
100 \\
100 \\
100 \\
100 \\
100 \\
100\end{array}$ & $\begin{array}{l}10 \\
10 \\
10 \\
10 \\
10 \\
10 \\
9\end{array}$ \\
\hline
\end{tabular}

Character of Material

(3) $1717.5^{\prime}$ @ $60^{\circ}$ to core is spotted by $1 / 8^{\prime \prime}$ glomeroporphritic, felsic clots.

1734-1749.5 Pyrox., fine, relatively unfractured; with scattered 1/8" amphibole phenocrysts; av. 12\% magnetite by vol. 1749.5-1753 Amphibole andesite dikelet, cutting core (3) $200 ; 1 / 8^{\prime \prime}$ amphibole phenocrysts constituteabout $20 \%$ of the rock.

1753-1774 Pyrox., fine, whth 1/8"-1/4" patches of felsics \& amphibole (less than 5\%); av. $12 \%$ magnetite by vol.; several $1 / 4^{\prime \prime}-1$ " felsic velnlets (a) $40^{\circ}$ to core.

1774-1780.5 Gabbro, fine to med., with 1rregular patches of pyroxentte; felsic velnlet @ $1779.5 !-1780.5$ ' (3) $60^{\circ}$ to core has several 1/2" random offshoot velnlets. 1780.5-1788 Amphibole andesite in a series of $1^{\prime \prime}$ dikelets cutting both the pyrox. \& the gabbro @ av. of 100 . $40^{\circ}$ to core; moderate fracturing.

$1788-1799.5$ Gabbro, fine to med., av. abt. $30 \%$ felsics, with a few Irregular patches of pyrox.; scattered 1/8" ampibole crystals; some disseminated pyrite; av. $8 \%$
magnetite by vol.

1799.5-1806 Amphibole andesite; 1/8" amphibole phenocrysts av. abt. $30 \%$; dikelet cuts gabbro @ $20^{\circ}$. 1806-1864 Gabbro, fine to med., along with nearly an equal amount of pyrox., flne-gratned, as 1 rregular patches \& lenses; some of the pyrox. Intercepts are over $2^{\prime}$ in length; both are relatively unfractured except for zones \& 1843' \& 1853-1854.5' where fractures and shears av. $100-20^{\circ}$ to core and contain some zeolltes, bematite, pyrite \& chlorite; $1 / 4$ " amphibole phenocrysts are ublquitous throughout both the prox. \& the gabbro, even cutting across contacts; the pyrox. av. 12\% magnetite by vol. \& the gabbro $8 \%$; some disseminated

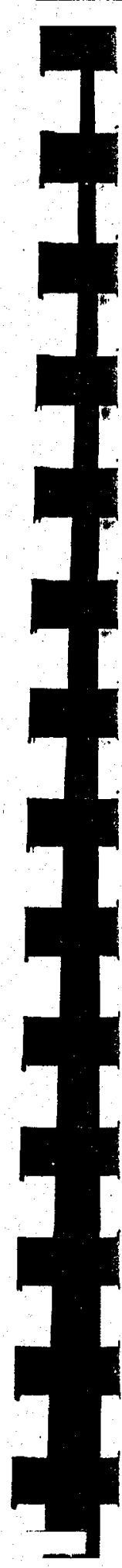


DRILC HOLE H-9

\begin{tabular}{lllllll} 
From & To & Distance & Core & $\begin{array}{c}\text { \% Core } \\
\text { Rec. }\end{array}$ & Magn \\
\cline { 1 - 1 } & 1870 & 1876 & 6 & 6 & 100 & 9 \\
1876 & 1882.5 & 6.5 & 6.5 & 100 & 9 \\
1882.5 & 1893 & 10.5 & 10.5 & 100 & 8
\end{tabular}

$\begin{array}{llllll}1893 & 1901 & 8 & 8 & 100 & 8 \\ 1901 & 1905 & 4 & 4 & 100 & 8 \\ 1905 & 1911 & 6 & 6 & 100 & 8 \\ 1911 & 1916.5 & 5.5 & 5.5 & 100 & 8 \\ 1916.5 & 1926.5 & 10 & 10 & 100 & 10 \\ 1926.5 & 1936 & 9.5 & 9.5 & 100 & 10 \\ 1936 & 1939 & 3 & 3 & 100 & 10 \\ 1939 & 1949 & 10 & 10 & 100 & 10 \\ 1949 & 1959 & 10 & 10 & 100 & 11 \\ & & & & & \\ & & & & & \\ 1959 & 1963 & 4 & 4 & 100 & 11 \\ 1963 & 1968 & 5 & 5 & 100 & 11 \\ 1968 & 1971 & 3 & & & \\ 1971 & 1975 & 4 & 3 & 100 & 13 \\ 1975 & 1985 & 10 & 4 & 100 & 13 \\ 1985 & 1987.5 & 2.5 & 10 & 100 & 13 \\ 1987.5 & 1992 & 4.5 & 4.5 & 100 & 13 \\ 1992 & 1996 & 4 & 4.5 & 100 & 13 \\ 1996 & 2000 & 4 & 4 & 100 & 13 \\ & & 4 & & 100 & 13\end{array}$
filling; considerable bematite is present; shears av Character of Material

1864-1883 Gabbro \& pyrox. as above, but highly sheared,

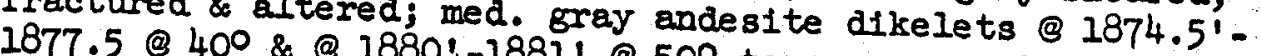
sheared \& oltered carbonate altered; zone is saturated by velnlets of carbonate \& zeolites; euhedral crystals of mesolite stilbite, calcite \& analcite indicate

1883-1920 Gabbro, fine to med., relatively unfractured; ' $1^{\prime}$ dikelets of amphibole andesite cut core (a) $20^{\circ}-40^{\circ}$; dikelet of med. Bray, massive andesite @ 1918'-1919' cuts core (a) 40\%; gabbro av. 8\% magnetite by vol.; trace of disseminated pyrite.

1920-1951 Gabbro \& pyrox., alternating in about equal proportions, the pyrox. occuoding as irregular lslands in the gabbro; minor fracturing, but a few zones are velned by carbonate \& altered; several $2 "$ amphibole andesite dikelets cut core @ 100-300; far fewer amphibole phenocrysts in this interval than above;

1951-1966 Pyrox., fine, with several I'-2' gabbro dikelets cutting core @ 40 ; minor fractiring; med. gray,

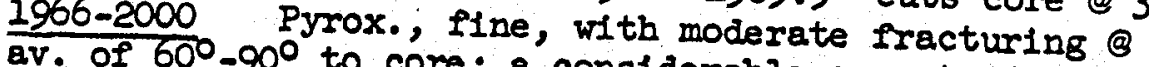
is finely disseminate; a considerable amount of pyrite fractures along with \& somewhat concentrated along magnetite av if a minute trace of chalcopyrite; veinlets av. $500^{\circ}$ by vol.; rare $1 / 2$ " felsic-emphibole patches are apperent, core; a few scattered blotite contrast to the above pyrox.) 
Started: June 24, 1959

Completed: July 1, 1959

Elevation (collar reference $\mathrm{H}-2$ ) $=/ 35$

Iocated $75^{\prime}$ due north of southeast corner of Claim 191

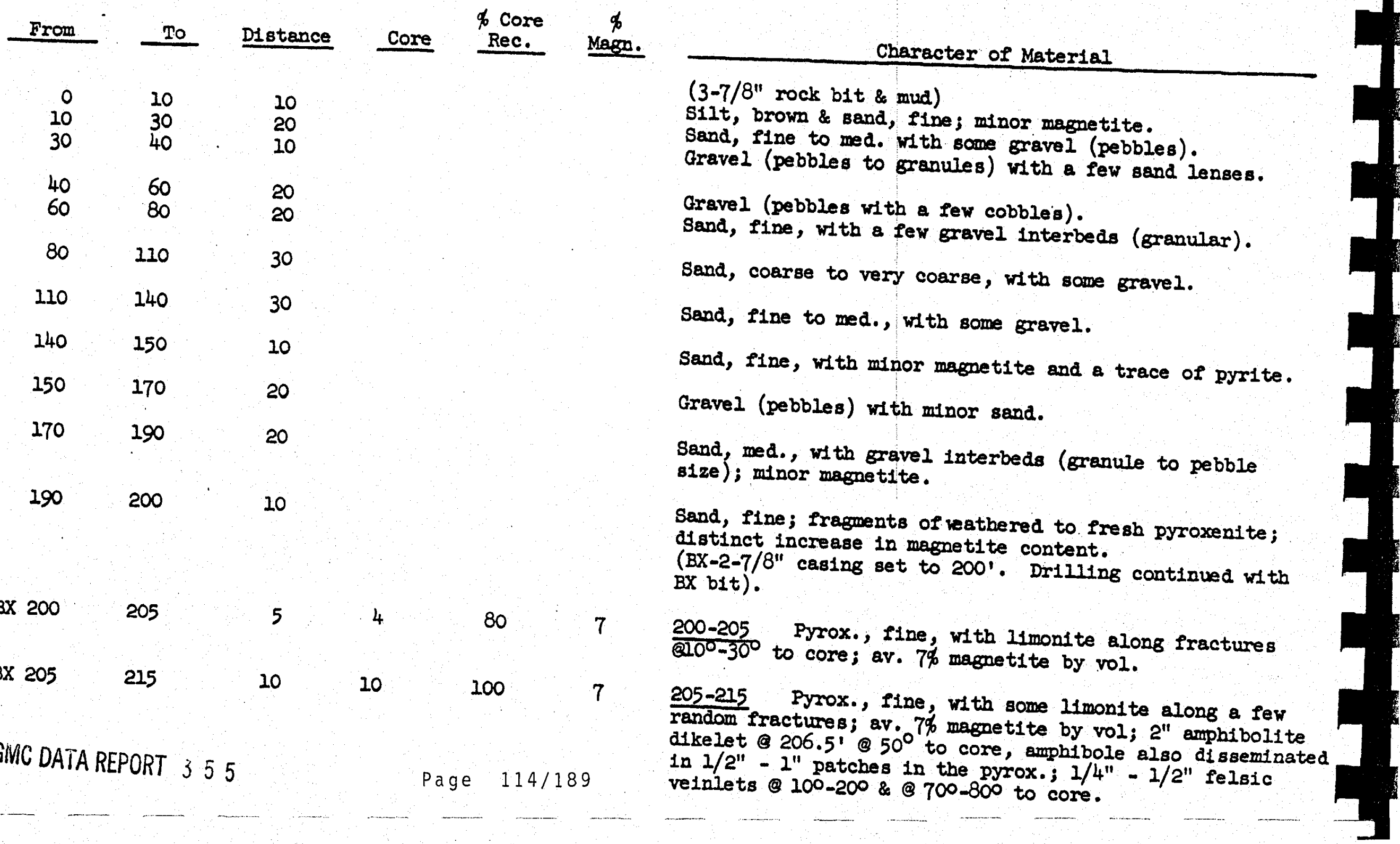




\begin{tabular}{|c|c|c|c|c|c|}
\hline Fram & To & Distance & Core & $\begin{array}{l}\text { of Core } \\
\text { Rec. }\end{array}$ & Magn \\
\hline $\begin{array}{l}215 \\
216 \\
218 \\
221 \\
228 \\
230.5 \\
235 \\
237 \\
240 \\
242 \\
245 \\
246 \\
247 \\
248 \\
250\end{array}$ & $\begin{array}{l}216 \\
218 \\
221 \\
228 \\
230.5 \\
235 \\
237 \\
240 \\
242 \\
245 \\
246 \\
247 \\
248 \\
250 \\
251\end{array}$ & $\begin{array}{l}1 \\
2 \\
3 \\
7 \\
2.5 \\
4.5 \\
2 \\
3 \\
2 \\
3 \\
1 \\
1 \\
1 \\
2 \\
1\end{array}$ & $\begin{array}{l}1 \\
0.5 \\
0.5 \\
6.5 \\
1.5 \\
4 \\
1.5 \\
1 \\
1.5 \\
2.5 \\
1 \\
0.5 \\
0.5 \\
1.5 \\
0.5\end{array}$ & $\begin{array}{r}100 \\
25 \\
15 \\
90 \\
60 \\
90 \\
75 \\
30 \\
75 \\
80 \\
100 \\
50 \\
50 \\
75 \\
50\end{array}$ & $\begin{array}{l}7 \\
7 \\
7 \\
8 \\
7 \\
7 \\
7 \\
7 . \\
7 \\
7 \\
7 \\
7 \\
7 \\
7 \\
7\end{array}$ \\
\hline $\begin{array}{l}251 \\
261 \\
262.5 \\
272\end{array}$ & $\begin{array}{l}261 \\
262.5 \\
272 \\
273\end{array}$ & $\begin{array}{l}10 \\
1.5 \\
9.5 \\
1\end{array}$ & $\begin{array}{l}10 \\
1.5 \\
9.5 \\
1\end{array}$ & $\begin{array}{l}100 \\
100 \\
100 \\
100\end{array}$ & $\begin{array}{r}8 \\
11 \\
9 \\
6\end{array}$ \\
\hline
\end{tabular}

Character of Material

(AX casing set to 215'. Drilling continued with AX bit). Il5-251 Pyrox, , flne to med., with intense, random scattered patches; 4 " 241.5' (3) 700 to core; grous of dike lets (3 226', 228' \& (1) $231^{\prime}-233^{\prime}$ \& felsic velnlets \& patches $(3) 242.5^{\prime}-245^{\prime}$.

$\begin{array}{ll}273 & 278 \\ 278 & 286 \\ 286 & 296 \\ 296 & 303.5 \\ 303.5 & 311.5 \\ 311.5 & 314\end{array}$

$\begin{array}{ccc}5 & 5 & 100 \\ 8 & 8 & 100 \\ 10 & 10 & 100 \\ 7.5 & 7.5 & 100 \\ 8 & 8 & 100 \\ 2.5 & 1.5 & 60\end{array}$

$\frac{251-274}{87.85}$ Pyrox., flne to med., with minor fracturing; 1" amphibole velnlet (3) 266' (3) patches of amphibole, andesite dikelets: I" (300 to core, 4" (3) 264' \& $400^{\circ} 30^{\circ}$ to core, 2" (9 257.5' dikelets 9260 ' \& a 272 (c) $50^{\circ}$ to core, (8) 256.5 ' (9) $40^{\circ}$ to felslc velniets @ 254' core \& (3) 273.5' \& $45^{\circ}$ to core to core, 268.5' (3) $30^{\circ}$ to 274-283

phenocrysts of epidote (3) dorite, whth $1 / 4 "-1 / 2^{\prime \prime}$ after olfvine. 283-314.5

patches, relatively ' fine with a few med. to coarse and in veinlets: I" 289.51 ; amphibole in patches (3) 100 to core; 2" amphtbole @ $20^{\circ}$ to core, $1^{\prime \prime}$ (c) 290.5' (c) $40^{\circ}$ to core \& (3) 305' (9) $80^{\circ}$ to 81 te dikelets (9) 303.5' andesite dikelets: $I^{\prime \prime}$ 2981

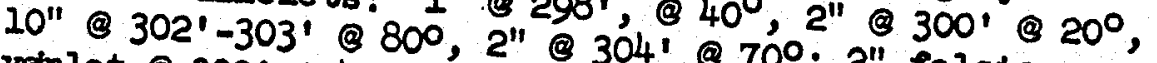
vemlet @303'@400; av. $7 \%$ magnetite. 


\begin{tabular}{|c|c|c|c|c|c|}
\hline From & To & Distance & Core & $\begin{array}{c}\text { \% Core } \\
\text { Rec. }\end{array}$ & $\begin{array}{c}\phi \\
\text { Magn }\end{array}$ \\
\hline $\begin{array}{l}314 \\
320.5 \\
325 \\
331 \\
337\end{array}$ & $\begin{array}{l}320.5 \\
325 \\
331 \\
337 \\
342\end{array}$ & $\begin{array}{l}6.5 \\
4.5 \\
6 \\
6 \\
5\end{array}$ & $\begin{array}{l}6.5 \\
1.5 \\
6 \\
6 \\
5\end{array}$ & $\begin{array}{r}100 \\
30 \\
100 \\
100 \\
100\end{array}$ & $\begin{array}{l}6 \\
6 \\
7 \\
6 \\
7\end{array}$ \\
\hline $\begin{array}{l}342 \\
346 \\
350 \\
353 \\
355\end{array}$ & $\begin{array}{l}346 \\
350 \\
353 \\
355 \\
362\end{array}$ & $\begin{array}{l}4 \\
4 \\
3 \\
2 \\
7\end{array}$ & $\begin{array}{l}3.5 \\
3.5 \\
3 \\
2 \\
7\end{array}$ & $\begin{array}{l}90 \\
90 \\
100 \\
100 \\
100\end{array}$ & $\begin{array}{r}10 \\
8 \\
8 \\
10 \\
8\end{array}$ \\
\hline $\begin{array}{l}362 \\
365 \\
366\end{array}$ & $\begin{array}{l}365 \\
366 \\
376\end{array}$ & $\begin{array}{r}3 \\
1 \\
10\end{array}$ & $\begin{array}{r}3 \\
1 \\
10\end{array}$ & $\begin{array}{l}100 \\
100 \\
100\end{array}$ & $\begin{array}{l}8 \\
9 \\
8\end{array}$ \\
\hline $\begin{array}{l}376 \\
386\end{array}$ & $\begin{array}{l}386 \\
396\end{array}$ & $\begin{array}{l}10 \\
10\end{array}$ & $\begin{array}{l}10 \\
10\end{array}$ & $\begin{array}{l}100 \\
100\end{array}$ & $\begin{array}{l}7 \\
8\end{array}$ \\
\hline
\end{tabular}

$\begin{array}{rrrrrr}396 & 406 & 10 & 10 & 100 & 7 \\ 406 & 416 & 10 & 10 & 100 & 7 \\ 416 & 424 & 8 & 8 & 100 & 17\end{array}$

$\frac{314.5-317}{317-333.5}$ Andes1te, w1th flow-banding, (3 $35^{\circ}$ to core. diorite dikelets Pyrox. med., with minor fracturing, with a 333.5-335 lets \& a few felsic velnlets. 335-342 Pyrox. fine to 314.5-317, (3) 400 to core. minor ampibole, av, $8 \%$ med., with minor fracturing; (a) 336' (9 800 \& 6" dike magnetite; 2 " andesite dikelet (3) 336.5' $80^{\circ}$.

fracturing; Pyrox. fine to med., with intense random patches of av. $9 \%$ magnetite; only a few scattered (3) 348' @ 500; 3" random stringer of vicinlet (3) $352^{\prime}$ (a) $30^{\circ}$; a few 360-361 Andesite, dark to \& zeolite.

361-374 Pyrox te, dark to med. Bray, (3) 300 to core. amphibole; ar. $8 \%$ ine with a few med. patches; minor amphibole andesite dikelet relatively unfractured; dikelet @ $367.5^{\prime}$ @ $40^{\circ}$.

374-390 Pyrox. med. to coarse, relatively unfractured; av. $7 \%$ magnet1te; amphibole in $1 / 2^{\prime \prime}-1 "$ patches \& in $1^{\prime \prime}$ $500,386^{\prime} @ 15^{\circ}, 1 / 2^{\prime \prime}$ (383.5'@400,384'@200,385.5 @ $390-393$ Pyrox. 1/2" felsic velnlet \& $385^{\prime}$ @ 200 . rare ambibole; in shain unfractured; av. $8 \%$ magnetite; coarse pyrox; $3^{\prime \prime}$ amphibole andesite with the overlying patches @ $390^{\prime}$ @ 400 . 393-396 Andesite,

6 Intercept of coarse pyrox. (3 $60^{\circ}$ to core. pyrox. (c) $394^{\prime}$, dike Intrudes

396-423.5 Pyrox. Ine to med., relatively unfractured av. 7\% magnetite; amphibole in patches \& veinlets. 6 " site dikelets () $396.5^{\prime}$ (9) 400 , $6^{\prime \prime}$ dikes \& veinlets; $6 "$ andefelsic veinlets; $I^{\prime \prime}$ (3) $400.5^{\prime}$ ' (3 $20^{\circ}$, $1 / 2^{\prime \prime}$ (9) 397.5 @ $30^{\circ}$;

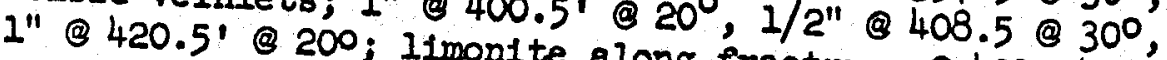
several $1 / 2^{\prime \prime}$ seams of magnetite \& $417.5^{\prime}-418.5^{\prime}$ ' $-423^{\prime}$; 


\begin{tabular}{|c|c|c|c|c|c|}
\hline From & To & Distance & Core & $\begin{array}{l}\text { \% Core } \\
\text { Rec. }\end{array}$ & $\begin{array}{c}\% \\
\text { Maga. }\end{array}$ \\
\hline $\begin{array}{l}424 \\
425 \\
425.5 \\
434.5\end{array}$ & $\begin{array}{l}425 \\
425.5 \\
434.5 \\
439\end{array}$ & $\begin{array}{l}1 \\
0.5 \\
9 \\
4.5\end{array}$ & $\begin{array}{l}1 \\
0.5 \\
3 \\
4\end{array}$ & $\begin{array}{r}100 \\
100 \\
30 \\
90\end{array}$ & $\begin{array}{l}6 \\
6 \\
7 \\
7\end{array}$ \\
\hline
\end{tabular}

$\begin{array}{ll}439 & 439.5 \\ 439.5 & 442 \\ 442 & 443 \\ 443 & 446 \\ 446 & 448 \\ 448 & 449 \\ 449 & 450 \\ 450 & 452 \\ 452 & 455 \\ 455 & 457 \\ 457 & 458 \\ 458 & 460 \\ 460 & 462\end{array}$

\section{$462 \quad 464.5$ \\ $\begin{array}{ll}464.5 & 467 \\ 467 & 468\end{array}$ \\ $468 \quad 471.5$}

$471.5 \quad 475$

0.5
2.5
1
3
2
1
1
2
3
2
1
2

\section{5}

$$
2
$$

0.5
460.5-462 Magnitiferous gabbro, flne, with some early, subhedral, elongate prisms of ilmenite (?); pseudomorphs of Ilmonite after pyrite (?) \& numerous rolds possibly caused by limonite removal; av. 15\% magnetite by vol.

462-471.5 Diorite, like $444.5^{\prime}-460.5^{\prime}$.

471.5-474 Andesite, med. to dark greenish-gray; cut by

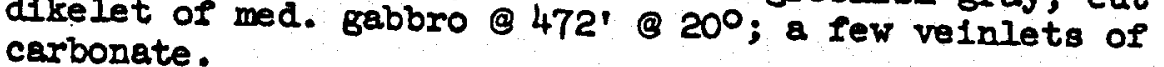




\begin{tabular}{|c|c|c|c|c|c|}
\hline From & To & Distance & Core & $\begin{array}{l}\% \text { Core } \\
\text { Rec. } \\
\end{array}$ & $\begin{array}{c}\not \\
\text { Magn. }\end{array}$ \\
\hline $\begin{array}{l}475 \\
479 \\
481 \\
482\end{array}$ & $\begin{array}{l}479 \\
481 \\
482 \\
485\end{array}$ & $\begin{array}{l}4 \\
2 \\
1 \\
3\end{array}$ & $\begin{array}{l}2 \\
1 \\
1 \\
2.5\end{array}$ & $\begin{array}{r}50 \\
50 \\
100 \\
80\end{array}$ & $\begin{array}{l}7 \\
7 \\
7 \\
7\end{array}$ \\
\hline $\begin{array}{l}485 \\
490 \\
495\end{array}$ & $\begin{array}{l}490 \\
495 \\
505\end{array}$ & $\begin{array}{r}5 \\
5 \\
10\end{array}$ & $\begin{array}{c}5 \\
4.5 \\
10\end{array}$ & $\begin{array}{r}100 \\
90 \\
100\end{array}$ & $\begin{array}{l}8 \\
8 \\
6\end{array}$ \\
\hline
\end{tabular}

6

\section{Character of Material}

474-485.5 Pyrox. Inne to med., Intensely sheared \& altered with talc. serpentine \& limonite along the shears \& veinlets av. $10^{\circ}-20^{\circ}$ to core.

485.5-499 Pyrox. Fine to med., with minor fracturing; of felsics; l" ; a few patches of amphibole \& a few of felsics; $l^{\prime \prime}$ andesite dikelet \& $486.5^{\prime}$ ' Q $70^{\circ}$ to core; 499-503.5 A $490^{\prime}$ \& $70^{\circ}$; a lew velnlets of carbonate. amphibole phenopibole andesite, dark greenish-gray with core; cut by 14" dikelet 1-3 ; cuts pyrox. B $10^{\circ}$ to $501.5^{\prime}$ \& $60^{\circ}$ to core.

503.5-512 Pyrox., f1ne to med., with minor fracturing; $70^{\circ}$ to core; $2^{\prime \prime}$ by vol.; a few $1 / 2^{\prime \prime}$ felsic velnlets av. $70^{\circ}$ to core; $2^{\prime \prime}$ med. grained gabbro dikelet \& $510^{\prime}$ ( $70^{\circ}$.

512-518.5 Andesite dikelet cutting pyrox \& 300 to core; Intercepts of med. pyrox. \& 514'-515' \& 516'-
516.5 '.

518.5-523 Pyrox. fine to med. With patches of felsics; $523-528$

pyrox. (3) $30^{\circ}$ to core \& cuts the grained gabbro $\& 10^{\circ}$. 528-532

some limonite along fractures.

Page $118 / 189$ 
Started: July 3, 1959

DRICI HOLE H-

Completed: Jury 8, 1959

Elevation (collar reference $\mathrm{E}-2$ ) $=120$

Iocated 12 feet east of south end center post of claim $13 \mathrm{E}$

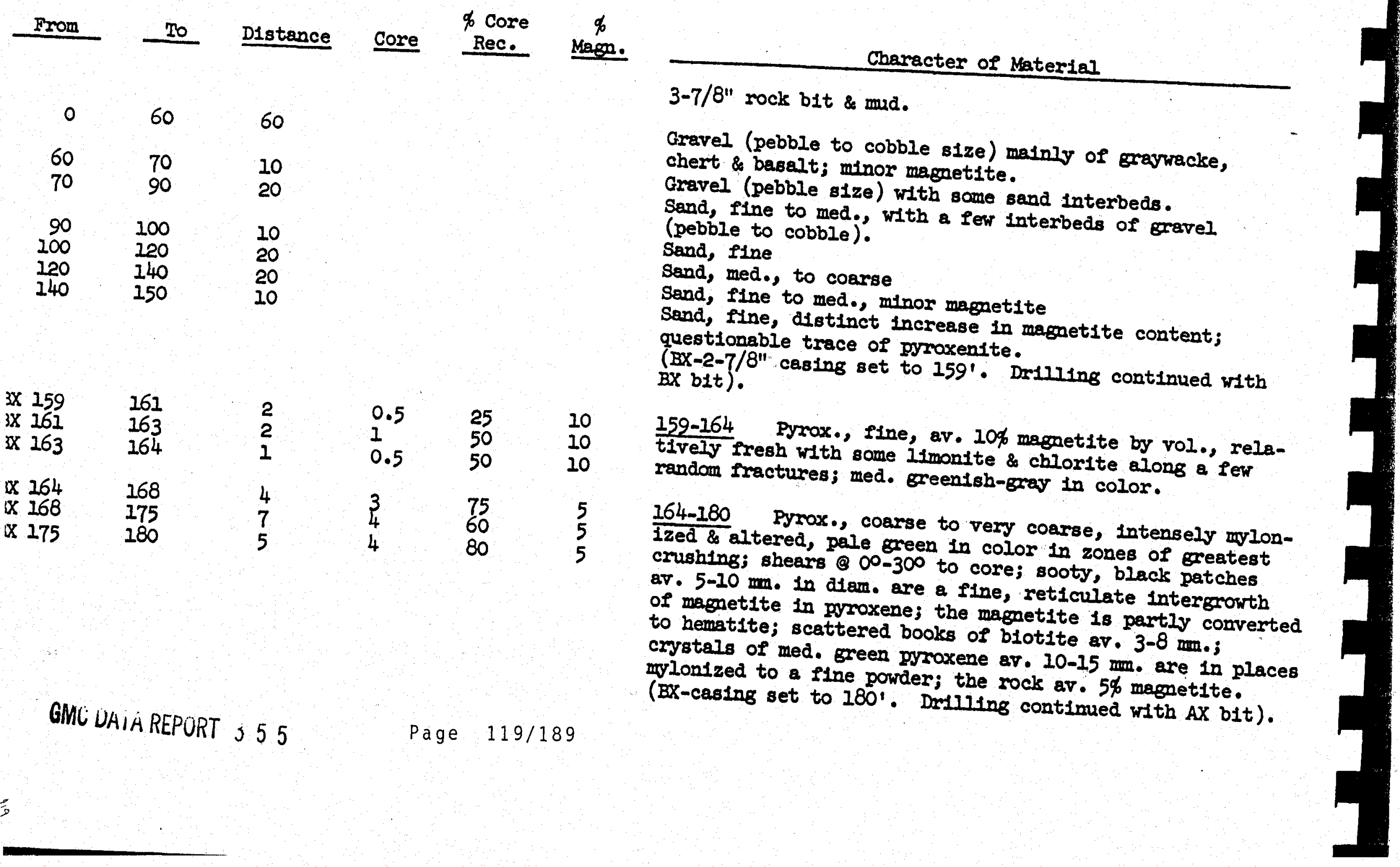


DRILC HOLE H-II

\begin{tabular}{lllllll} 
From & To & Distance & Core & $\begin{array}{c}\text { \% Core } \\
\text { Rec. }\end{array}$ & Magn. \\
\cline { 6 - 7 } & & & & & & \\
180 & 182 & 2 & 1.5 & 75 & 6 \\
182 & 184.5 & 2.5 & 2 & 80 & 6 \\
184.5 & 188 & 3.5 & 3 & 85 & 6 \\
188 & 191 & 3 & 3 & 100 & 6 \\
191 & 199.5 & 8.5 & 8 & 90 & 6 \\
199.5 & 206 & 6.5 & 6 & 90 & 6
\end{tabular}

206

211

5

3

60

5

206-209 Pyrox., coarse, Intensely sheared \& molonized, shears av. $10^{\circ}-30^{\circ}$ to core.

209-211 Pyrax., coarse, as above, but only moderately sheared; av. $6 \%$ magnetite by rol.

$\begin{array}{llllll}211 & 214 & 3 & 2 & 70 & 6 \\ 214 & 216 & 2 & 1.5 & 75 & 5 \\ & & & & & \\ 216 & 218 & 2 & 2 & 100 & 5 \\ 218 & 220 & 2 & 1.5 & 75 & 5 \\ 220 & 222.5 & 2.5 & 2 & 80 & 5 \\ 222.5 & 226.5 & 4 & 3 & 75 & 5 \\ 226.5 & 233 & 6.5 & 4 & 60 & 5 \\ 233 & 237 & 4 & 4 & 100 & 5 \\ 237 & 240 & 3 & 2.5 & 80 & 7 \\ 240 & 245 & 5 & 4.5 & 90 & 6\end{array}$

2Il-213 Pyrox., coarse, I1ke 206-209', Intensely. mylonized.

213-215 Pyrox., coarse, only moderately mylonized \& sheared; av. 5\% magnet1te; considerable conversion of magenetite to hematite.

215-235.5 Pyrax., coarse, intensely mylontzed \& sheared in several zones such as $3225.5^{\prime}$ the pyraxene is crushed to a fine light green powder, streaked by black and red from magnetite and hematite; shears av. $25^{\circ}$ to core.

235.5-243 Pyrox., coarse, moderate to slight mylonization \& shearing; magnetite-pyroxene in patches up to $I^{\prime \prime}$ in diem., magnetite rich zone a 239.5; magnetite av. $6 \%$ by vol.

$\begin{array}{llllll}245 & 247.5 & 2.5 & 2 & 80 & 6\end{array}$

243-246 Pyrox., coarse, as above but with Increased ujlonization \& shearing. 


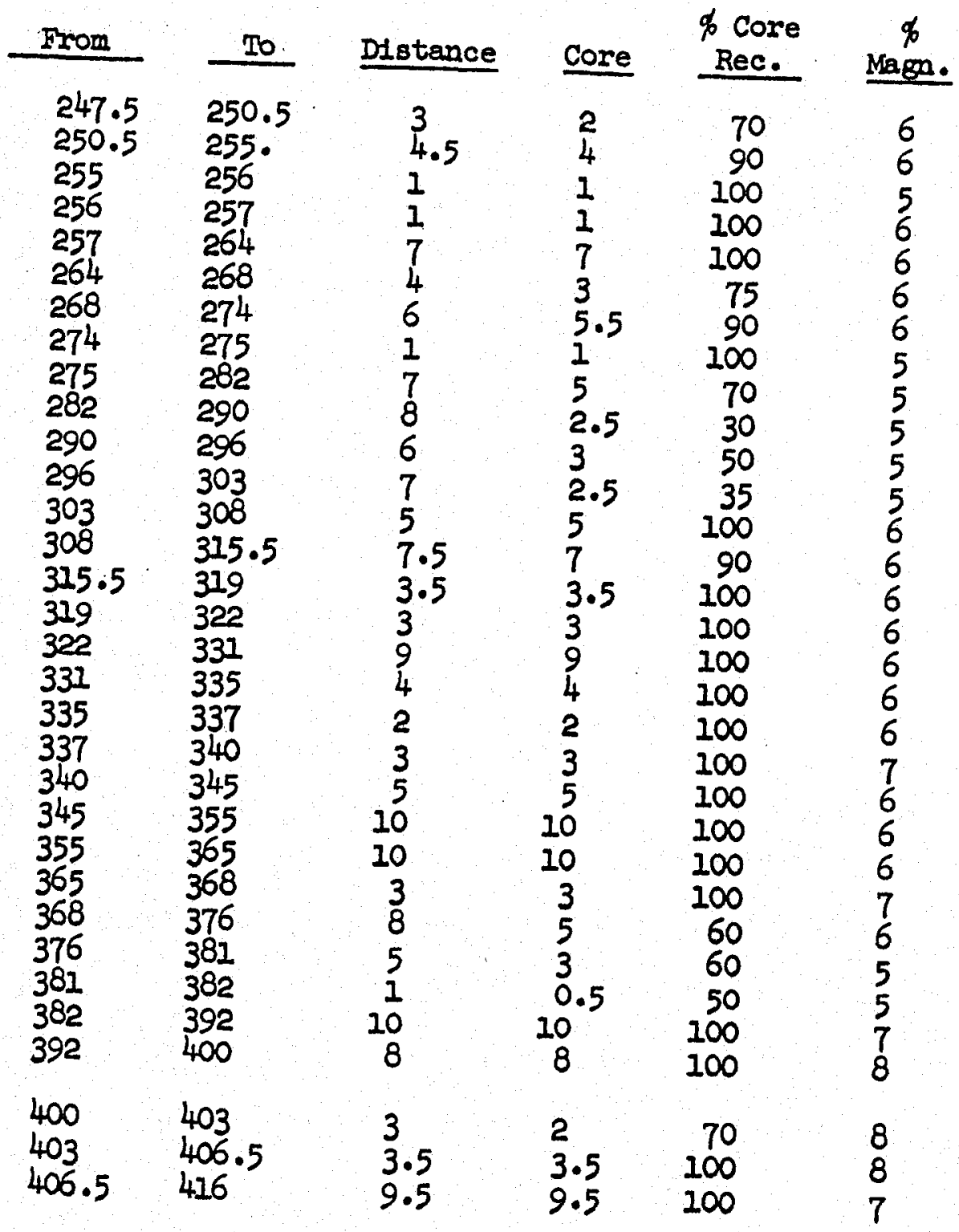

Character of Matertal

246-280 Pyrox., coarse, relatively unmylonized except for zones @ 255-256', 267.5-268.5'\& @ 274.5-275'; 1/4' carbonate-blotite veinlet (1) $255.5 !$ ! $10^{\circ}$ to core; magnetite in intergrowth with pyroxene av. $6 \%$ by rol.

280-304 Pyrox., coarse, intensely wrlonized \& sheared; talcose shears av. $\infty^{\circ}-20^{\circ}$ to core; magnetite av. $5 \%$ by

304-372.5 Pyrox., coarse to very coarse; relatively unmylonized; rare shears are (3) 100-30 to core, striations $3^{\prime \prime}$ patch of blotite near horlzontal (@ $75^{\circ}-90^{\circ}$ to core); dikelet 370.51 diorite (fine-grained)

(8) 400 to core; av. 1/2"-I" in lin patches the petches) 3271 ' magnetite-rich zones (Broupings of $351.5^{\prime}, 353.5-354.5^{\prime}, 337^{\prime}, 340.5^{\prime}-341^{\prime}, 346 '-346.5^{\prime}, 347.5$ (9) $365^{\prime}-366^{\prime}$ \& \& $370-371$ ', 368', 370'; very coarse pyrox. av. $6 \%$ magnetite.

372.5-382 Pyrox., coarse, Intensely mylonized \& sheared with a few thin carbonate velnlets; minor magnetite

382-396 Pyrox., coarse, relatively unfractured; almost less biotite the menetite-pyroxene intergrowth with above; ar. $7 \%$ magenetite by rol.

except (898) magnetite-pyroxe fracturing av. $50^{\circ}-80^{\circ}$ to core; patches 397 ' 
DRIIC HOLE H-II

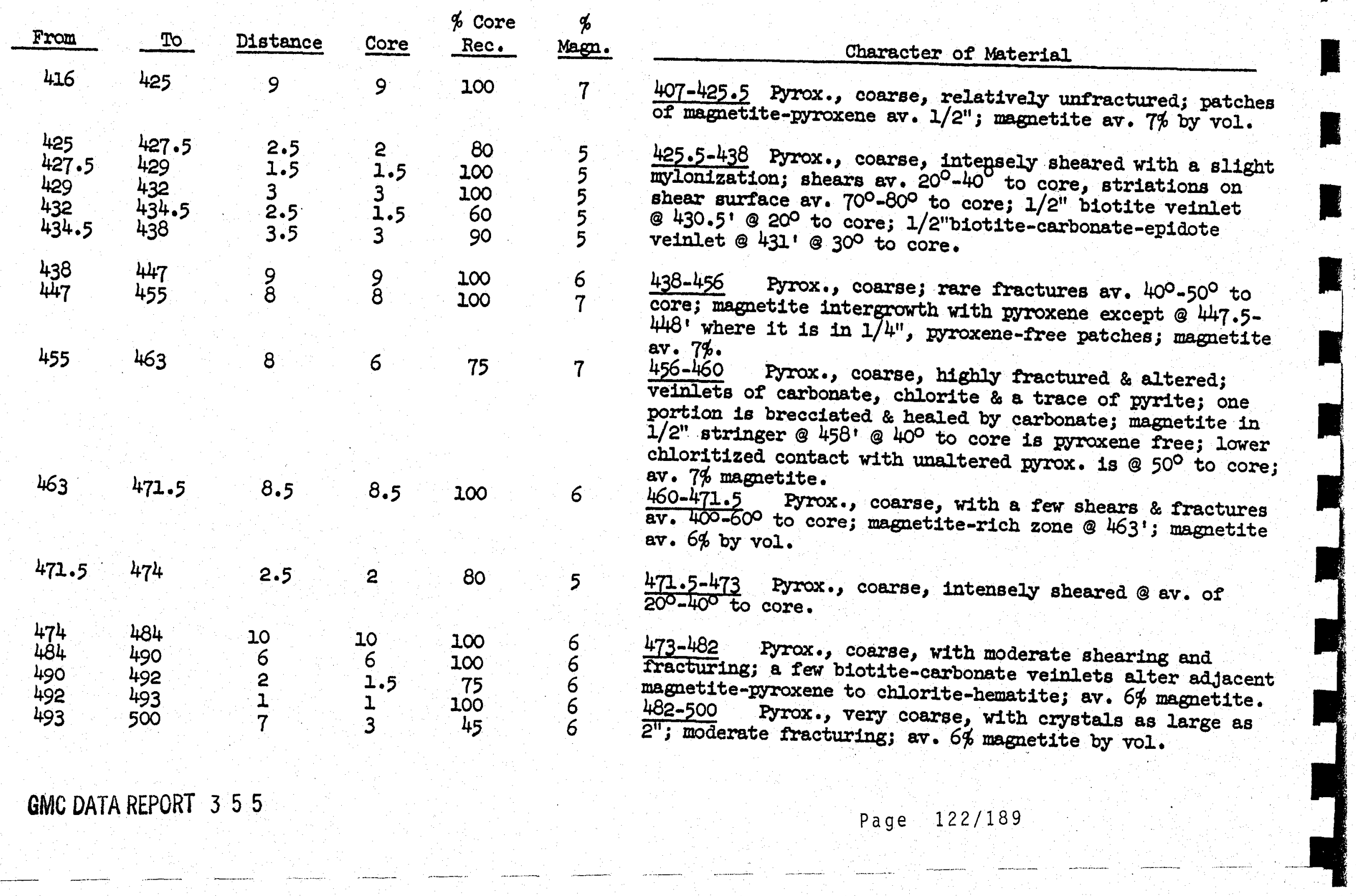


Started: July 10, 1959

Completed: July 18, 1959

Elevation (collar reference H-2) $\neq \$ 80$

Located $20 \mathrm{I}$ Claim, 400 feet due north from southwest comer

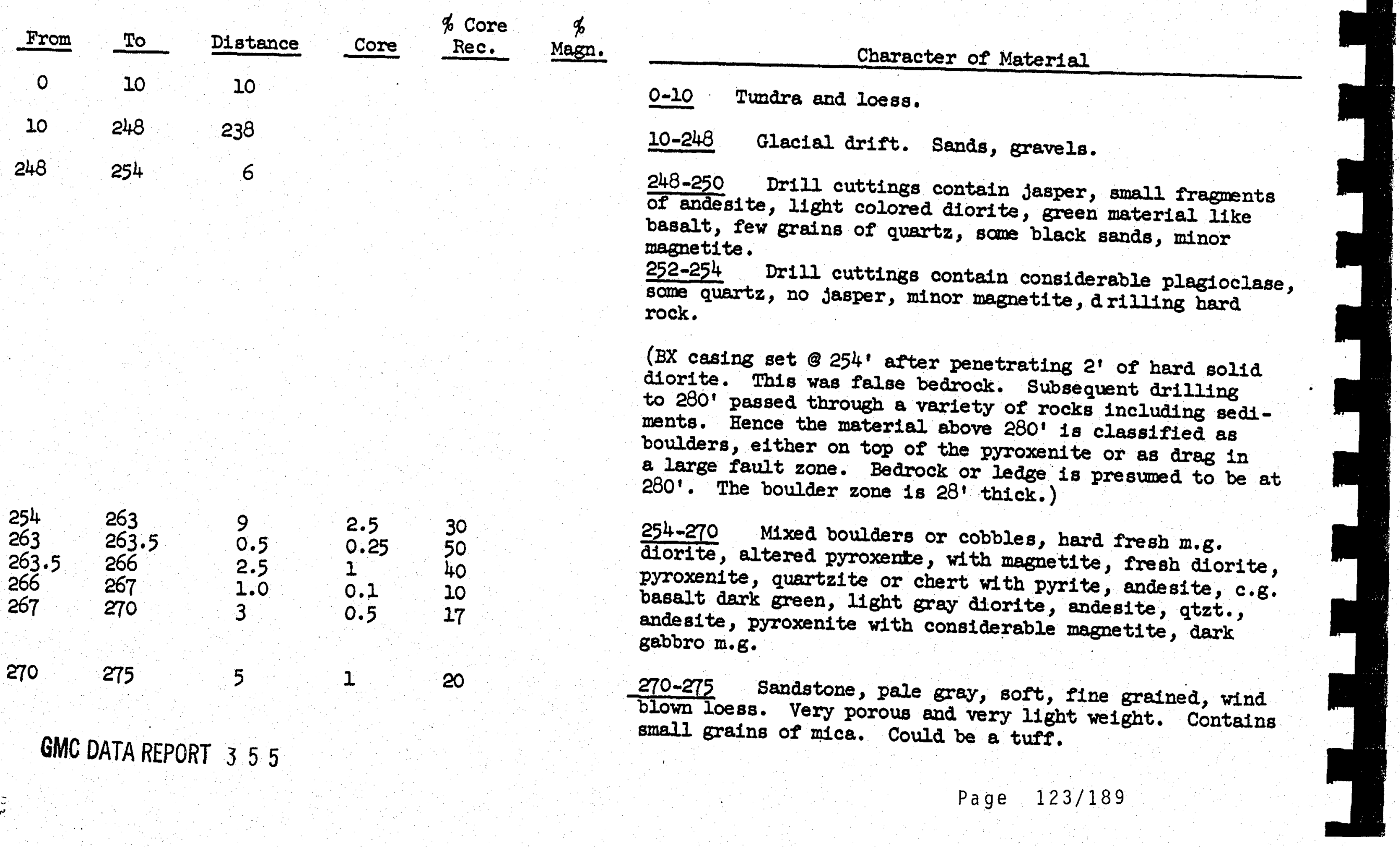


DRILC HOLE H-12 Cont'd

\begin{tabular}{|c|c|c|c|c|c|c|}
\hline From & To & Distance & Core & $\begin{array}{l}\text { of Core } \\
\text { Rec. }\end{array}$ & $\begin{array}{c}\% \\
\text { Magn. }\end{array}$ & Character of Material \\
\hline 275 & 280 & 5 & 1 & 20 & & $\frac{275-280}{\text { magnetite, bedded qtzt. or chert, all boulders. }}$ \\
\hline $\begin{array}{l}280 \\
284 \\
286 \\
288 \\
292 \\
296 \\
301 \\
304 \\
307 \\
308 \\
310 \\
313 \\
317 \\
317\end{array}$ & $\begin{array}{l}284 \\
286 \\
288 \\
292 \\
296 \\
301 \\
304 \\
307 \\
308 \\
310 \\
313 \\
317 \\
318.5 \\
318.5\end{array}$ & $\begin{array}{l}4 \\
2 \\
2 \\
4 \\
4 \\
5 \\
3 \\
3 \\
1 \\
2 \\
3 \\
4 \\
1.5 \\
1.5\end{array}$ & $\begin{array}{l}3.5 \\
2 \\
2 \\
4 \\
4 \\
5 \\
3 \\
3 \\
0.5 \\
2 \\
3 \\
4 \\
1.5 \\
1.5\end{array}$ & $\begin{array}{r}87 \\
100 \\
100 \\
100 \\
100 \\
100 \\
100 \\
100 \\
50 \\
100 \\
100 \\
100 \\
100 \\
100\end{array}$ & $\begin{array}{l}6 \\
6 \\
6 \\
6 \\
7 \\
7 \\
6 \\
6 \\
6 \\
6 \\
6 \\
6 \\
7 \\
7\end{array}$ & 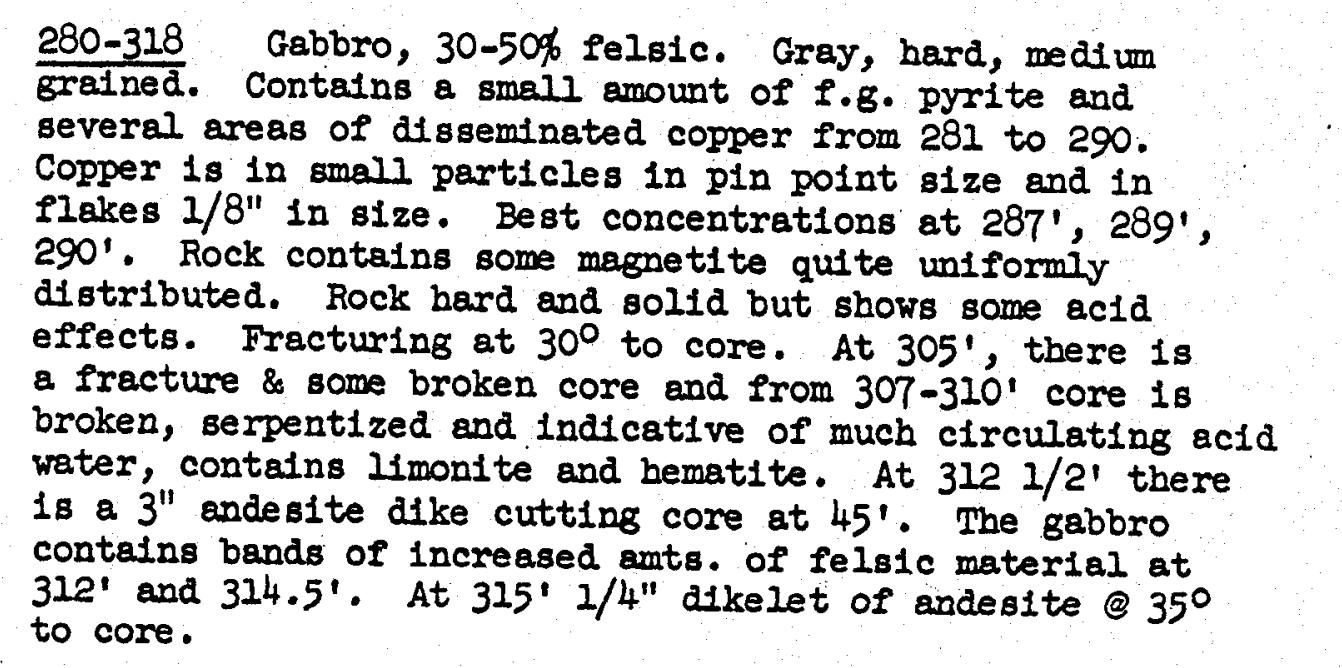 \\
\hline 318.5 & 321.5 & 3 & 3 & 100 & 5 & 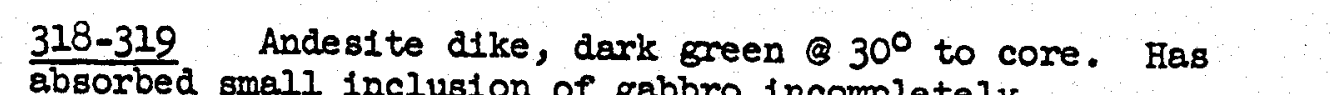 \\
\hline 321.5 & 324 & 2.5 & 2.5 & 100 & 6 & $\begin{array}{l}\frac{319-323}{323-323} 1 / 2 \text { Gabro, same as last. } \\
\text { May be along a dikelet. Kaolinized. }\end{array}$ \\
\hline $\begin{array}{l}324 \\
327 \\
330 \\
332\end{array}$ & $\begin{array}{l}327 \\
330 \\
332 \\
337\end{array}$ & $\begin{array}{l}3 \\
3 \\
2 \\
5\end{array}$ & $\begin{array}{l}3 \\
3 \\
2 \\
5\end{array}$ & $\begin{array}{l}100 \\
100 \\
100 \\
100\end{array}$ & $\begin{array}{l}6 \\
7 \\
6 \\
6\end{array}$ & $\begin{array}{l}323 \mathrm{l} / 2-336 \text { Gabbro same as last with perhaps a more } \\
\text { unfform distribution of felsic minerals (f - } 40 \% \text { ). Fracturing } \\
\text { (3) } 30^{\circ} \text { to core. Although fractured rock has not been altered } \\
\text { much, there is an Increase in quantity of pyrite to } 327 \text {. } \\
\frac{336-337}{\text { gularly. Contact, gabbro and pyroxenite, follows core irre- }}\end{array}$ \\
\hline $\begin{array}{l}337 \\
339\end{array}$ & $\begin{array}{l}339 \\
346.5\end{array}$ & $\begin{array}{l}2 \\
7 \cdot 5\end{array}$ & $\begin{array}{l}2 \\
7.5\end{array}$ & $\begin{array}{l}100 \\
100\end{array}$ & $\begin{array}{l}8 \\
6\end{array}$ & $\begin{array}{l}337-341 \\
\text { native copper near zone of increased amt. of felsic minerals. }\end{array}$ \\
\hline GMG D & REPORT & 355 & & & & Page $124 / 189$ \\
\hline
\end{tabular}


DRILI HOLE H-12

\begin{tabular}{lllllll} 
From & To & Distance & Core & $\begin{array}{c}\text { \% Core } \\
\text { Rec. }\end{array}$ & $\begin{array}{c}\text { \% } \\
\text { Magn. }\end{array}$ \\
\cline { 3 - 5 } 438 & 442.5 & 4.5 & 4.5 & 100 & 7 \\
442.5 & 449 & 6.5 & 6.5 & 100 & 6 \\
449 & 451 & 2 & 2 & 100 & 6 \\
451 & 456 & 5 & 4 & 80 & 6 \\
456 & 465 & 9 & 9 & 100 & 6 \\
465 & 475 & 10 & 10 & 100 & 7 \\
475 & 482 & 7 & 7 & 100 & 8
\end{tabular}

Character of Material

of pyrite, some limonite residual from pyrite @ 444'. Core continues uniform to 468 . Fracture (a $450 \mathrm{with}$ epidote. Several 1 to 3-1nch dikelets of andesite \& 453', 457', 459' and 460 , cut core at $30^{\circ}$. Very minor pyrite. Contains a few small xenoliths of pyroxentte.

468-481 Same as last. Contains amall Inclusions or xenoliths of pyroxenite. Considerable f.g. magnetite locally more than $10 \%$.

$481-482$ Andesite dike cutting $30^{\circ}$ across core; shows banding, f.g., gray green.

$\begin{array}{llllll}482 & 491 & 9 & 9 & 100 & 8 \\ 491 & 499 & 8 & 8 & 100 & 7 \\ 499 & 500 & 1 & 1 & 100 & 8 \\ 500 & 506 & 1 & 6 & 100 & 6 \\ 506 & 507.5 & 1.5 & 1.5 & 100 & 5 \\ 507.5 & 517 & 9.5 & 9.5 & 100 & 5\end{array}$

482-504 Gabbro - same as 401-481. Contains more inclusions, amall, of pyroxentte. Several thin 1/16" velnlets of calcite, accompanying inclusion. Contains scattered minor amounts of pyrite. Appears more dioritic.

504-513 2/2 Contact, andesite dike and gabbro - follows core for 10 feet, practically vertical $\left(f-80^{\circ}\right)$. Dike portion contains little magnetite. Dike contains more calcite, slightly russy, shows flow banding. $5131 / 2-5151 / 2$ Gabbro, m.g., greenlsh gray contains magnetite $-7 \%$ by vol.

$5151 / 2-517$ Andesite dike- fresh, hard, no magnetite calcite velniet (B) contact.

$\begin{array}{llllll}517 & 525 & 8 & 8 & 100 & 6 \\ 525 & 535 & 10 & 10 & 100 & 7 \\ 535 & 545 & 10 & 10 & 100 & 8\end{array}$

517-549 Gabbro, same as last. At $5201 / 2$ to $5211 / 2$ dike of andesite contains velnlets of calcite, but no magnetite. Rock is softer, chloritized and fractured along the core. One fracture contains a coating of bematite for a length of 3 feet. Core shows an increase of pyroxentte zenoliths.

GMC DATA REPORT 3 \& 5 
There are fractures showing slickensldes most of whtch have coarser grained from 530', horlzontal movement. Becomes of magnetite. Core is and perhaps an increased amount filled with carbonate veinlured at $40^{\circ}$ to core. Some are dike of andesite (containsets. At $546 \mathrm{l} / 2$ there is a $1 / 2^{\prime \prime}$ f.g., dark green. At 547 magnetite) cutting core (e) 250 $1 / 2^{\prime \prime}$ wide of earlier crystall there is a long (2') $\mathrm{rib}$

552

7

7

100

562

10

10

100

570

8

8
100 magnetite than younger gabbro. Minor fracturing (3) $30^{\circ}$.

$549-552$

Mixed zone of gabbro and pyroxenite with pyrox. containing much more magnetite. The zenoliths of pyrox. show a maximum length of $f-6^{\prime \prime}$, with irregular contacts.

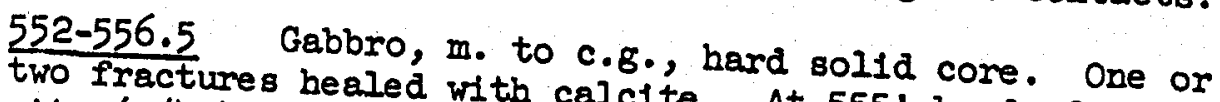
nite (3/4") (8) $30^{\circ}$ to with calc1te. At 555' band of pyroxe amphibole.

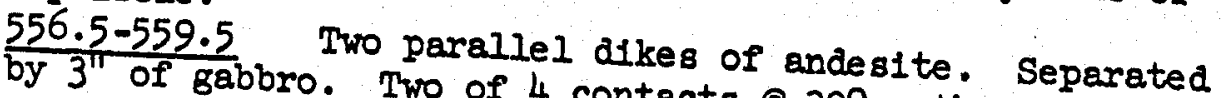
present. Dike pale Two of 4 contacts (a) 300- other 2 not 559.5-561 Gabbro, same as last, f.g. shows slight banding. minor fractures @ 259 as last, m. to c.g., w1th few bro \& dikes.

561-565 Large inclusion of pyroxentte, magnetite intruded by gabbro pyroxenite, m.g. to f.g., $12 \%$ cut across contact @ $30^{\circ}$ \& $45^{\circ}$ At contact zone 2 velnlets At $563^{\prime}$ a dike of gabbro andealte contact $845^{\circ}$, andesates the pyroxenite. Gabbro to core. Simliar $45^{\circ}$, andesite -pyroxenite contact @ $35^{\circ}$ to core. Following andesite $1965^{\prime}$ with both dips @ $45^{\circ}$ 565-567 Andesite andesite is $2^{\text {n }}$ of gabbro: magnetite. 
DRILI HOLE H-12 Cont'd

\begin{tabular}{|c|c|c|c|c|c|c|}
\hline From & To & Distance & Core & $\begin{array}{l}\% \text { Core } \\
\text { Rec. }\end{array}$ & $\begin{array}{c}\text { \% } \\
\text { Magn. }\end{array}$ & Character of Material \\
\hline & & & & & & $\begin{array}{l}567-570 \text { Gabbro; contact with above is } f-15^{\circ} \text { to core, } \\
\text { wavy Gabbro is coarser grained, contains less magnetite. } \\
\text { At } 568 \text {, to } 569^{\prime} \text { pyroxentte containing considerable } 12 \% \\
\text { magnetite. }\end{array}$ \\
\hline $\begin{array}{l}570 \\
580\end{array}$ & $\begin{array}{l}580 \\
590\end{array}$ & $\begin{array}{l}10 \\
10\end{array}$ & $\begin{array}{l}10 \\
10\end{array}$ & $\begin{array}{l}100 \\
100\end{array}$ & $\begin{array}{l}7 \\
7\end{array}$ & $\begin{array}{l}\text { 570-573 Pyroxenite, dark green, hard, 1.8., contains } \\
\text { considerable } f .8 . \text { magnetite. Contact @ } 570 @ 100 \text { to core } \\
\text { and } @ 573 \text { is } 200 \text { to core. }\end{array}$ \\
\hline 590 & 600 & 10 & 10 & 100 & 8 & $\begin{array}{l}573-600 \text { Gabbro, same as last, coarse grained to medium. } \\
\text { Contains xenoliths of pyroxenite, small, } 1^{\prime \prime} \text { to } 2^{\prime \prime} \text { size. } \\
\text { At } 575^{\prime} \text { to } 576 \text { is andesite dike showing flow banding, cuts } \\
\text { core (a) } 45^{\circ} \text {. At } 583 \text { to } 584 \text { xenollth of pyroxenite containing } \\
12 \% \text { magnetite. Very slight amount of fracturing } 945^{\circ} \text { and } \\
\text { at } 15^{\circ} \text { to core. The last } 10 \text { feet contains an increased } \\
\text { amount of pyroxenite xenoliths perhaps } 20-25 \% \text {. }\end{array}$ \\
\hline
\end{tabular}

Page $128 / 189$ 


\section{DRILL HOLE H-13}

Started:

July 23, 1959

Completed: July 29, 1959

Elevation (collar reference $\mathrm{H}-2$ ) $=455^{\prime}$

Located $12^{\prime}$ east and $15^{\prime}$ north of the south-end center post of claim $12 \mathrm{~J}$.

From To Distance Core \% Rece Magn.

\section{Charecter of Material}

$\begin{array}{rrr}0 & 20 & 20 \\ 20 & 40 & 20 \\ 40 & 100 & 60 \\ 100 & 140 & 40 \\ 140 & 150 & 10 \\ 150 & 190 & 40 \\ 190 & 210 & 20 \\ 210 & 220 & 10 \\ 220 & 250 & 30 \\ 250 & 260 & 10 \\ 260 & 330 & 70\end{array}$

( $41 / 2^{\prime \prime}$ rock b1t \& mud)

Silt, brown, libaltic.

Sand, fine to med.; minor magnetite.

Gravel, granule to pebble, with minor interbeds of sand.

Sand, fine, with minor gravel, pebble size.

Gravel, Branule size, with fine sand.

Sand, fine to med.

Sand, fine to med., with minor gravel, granule.

Sand, fine to med.; slight Increase in magnetite content.

Sand, fine to med., with a few interbeds of gravel, granule to pebble size.

Sand, fine to med.; distinct increase in magnetite \& in pyroxene content.

Sludge is almost entirely of sub-angular to sub-rounded grains of pyroxene \& magnetite (at least 30\%). Pyroxenlte ledge may be as high as $250^{\prime}-260^{\prime}$. If 80 ; the drilling ease indicates extreme weathering and/or fracturing. The interval 250'-330' may be of pre-glacial, fluvial sediments derived primarily from the pyroxenite mass. Some concentration of magnetite would thus be expected (suggested by Mayer Hansen).

(NX-casing set to $330^{\circ}$ ) 
RIIL HOLE H-13 Cont'd

\begin{tabular}{|c|c|c|c|c|c|c|}
\hline From & To & Distance & Core & $\begin{array}{l}\text { \% Core } \\
\text { Rec. }\end{array}$ & $\begin{array}{c}\% \\
\text { Maga. }\end{array}$ & Character of Material \\
\hline$\times 330$ & 335 & 5 & 2 & 40 & 3 & $\begin{array}{l}\text { 330-335 Diorite to monzonite, equigranular to porphyri- } \\
\text { tic; 1-2 subhedral to euhedral phenocrysts of plasio- } \\
\text { clase in a fine to very fine-grained groundmass of alkall } \\
\text { feldspar, plag1oclase and minor amphibole, b1otite, } \\
\text { chlorite and magnetite; fracturing is moderate. } \\
\text { (BX-casing set to } 335 \text { !) }\end{array}$ \\
\hline $\begin{array}{l}335 \\
336\end{array}$ & $\begin{array}{l}336 \\
339\end{array}$ & $\begin{array}{l}1 \\
3\end{array}$ & $\begin{array}{l}1 \\
1.5\end{array}$ & $\begin{array}{r}100 \\
50\end{array}$ & $\begin{array}{l}3 \\
3\end{array}$ & 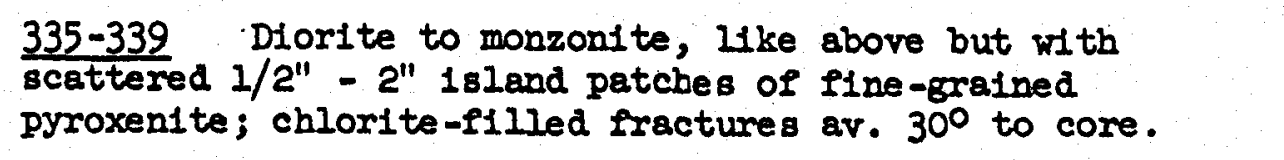 \\
\hline $\begin{array}{l}339 \\
343 \\
346 \\
348 \\
350 \\
355 \\
358 \\
360 \\
362 \\
365\end{array}$ & $\begin{array}{l}343 \\
346 \\
348 \\
350 \\
355 \\
358 \\
360 \\
362 \\
365 \\
369\end{array}$ & $\begin{array}{l}4 \\
3 \\
2 \\
2 \\
5 \\
3 \\
2 \\
2 \\
3 \\
4\end{array}$ & $\begin{array}{l}0.5 \\
2.5 \\
1 \\
1 \\
2 \\
0.5 \\
1 \\
1.5 \\
2 \\
2.5\end{array}$ & $\begin{array}{l}10 \\
80 \\
50 \\
50 \\
40 \\
20 \\
50 \\
75 \\
70 \\
60\end{array}$ & $\begin{array}{l}5 \\
5 \\
5 \\
5 \\
5 \\
5 \\
5 \\
5 \\
5 \\
5\end{array}$ & 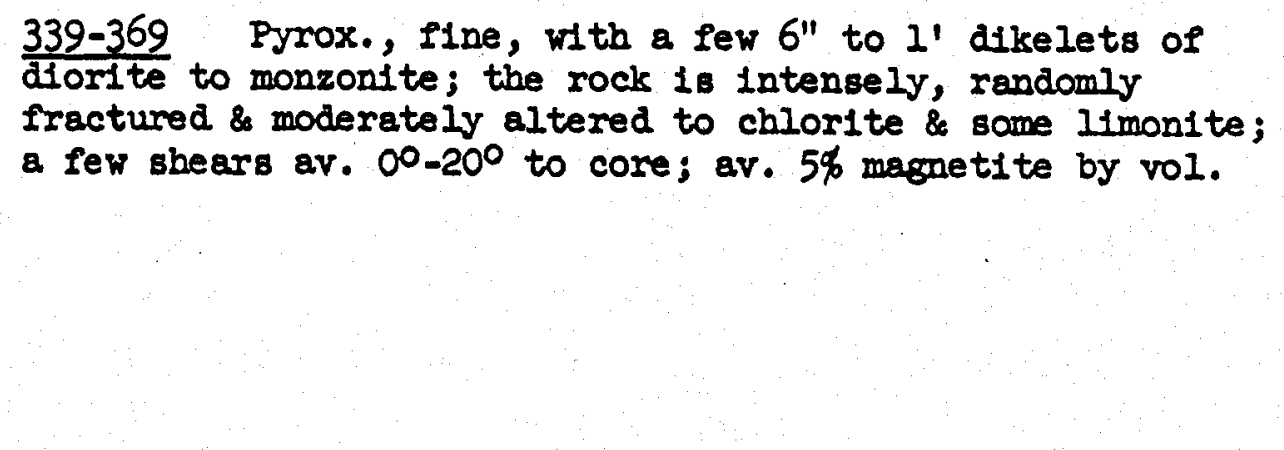 \\
\hline 369 & 371 & 2 & 1.5 & 75 & 4 & $\frac{369-372.5}{d i s 8 e m i n a t e d}$ felsics; moderate fracturing $10-20 \%$ finely \\
\hline $\begin{array}{l}371 \\
378 \\
380 \\
384\end{array}$ & $\begin{array}{l}378 \\
380 \\
384 \\
391\end{array}$ & $\begin{array}{l}7 \\
2 \\
4 \\
7\end{array}$ & $\begin{array}{l}6.5 \\
1.5 \\
4 \\
7\end{array}$ & $\begin{array}{r}90 \\
75 \\
100 \\
100\end{array}$ & $\begin{array}{l}5 \\
5 \\
5 \\
5\end{array}$ & 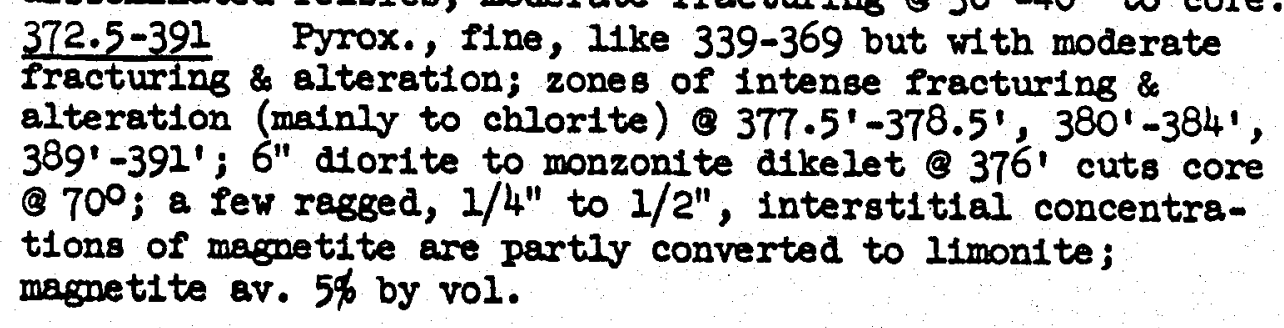 \\
\hline \multicolumn{7}{|c|}{ GMC DATA REPORT 355} \\
\hline
\end{tabular}




\begin{tabular}{|c|c|c|c|c|}
\hline From & To & Distance & Core & $\begin{array}{c}\text { \% Core } \\
\text { Rec. }\end{array}$ \\
\hline $\begin{array}{l}391 \\
395 \\
400 \\
407 \\
409 \\
415 \\
421 \\
426 \\
432 \\
440 \\
444\end{array}$ & $\begin{array}{l}395 \\
400 \\
407 \\
409 \\
415 \\
421 \\
426 \\
432 \\
440 \\
444 \\
449\end{array}$ & $\begin{array}{r}4 \\
5 \\
7 \\
2 \\
6 \\
6 \\
5 \\
6 \\
8 \\
4 \\
5\end{array}$ & $\begin{array}{l}4 \\
5 \\
7 \\
1.5 \\
6 \\
6 \\
5 \\
6 \\
8 \\
4 \\
5\end{array}$ & $\begin{array}{r}100 \\
100 \\
100 \\
75 \\
100 \\
100 \\
100 \\
100 \\
100 \\
100 \\
100\end{array}$ \\
\hline
\end{tabular}

Character of Matertal

391-419 Pyrox., f1ne, w1 th m1nor fracturing, except for zone of intense mylonization \& alteration (9 406.5'-409.5' and (1) 410.5'-412.5'; magnet1te av. 118 by vol.; a few ragged, 1/2" patches of magnetite (9 413' \& 417'; diorite to monzonite dikelet (3 $409.5^{\prime}-410.5^{\prime}$ cuts core (3) $30^{\circ}$. 419-447.5 Pyrox, coarse to med., with a few zones of fine grained pyrox.; the majority of the magnetite is in intergrowth patches with pyroxene, but in the flner-grained phases the magnet1te $1 \mathrm{~s}$ in pyroxene-Iree, ragged, interstitial granules; magnetite averages $4 \%$ by volume where $1 t$ occurs in intergrowth, and $7-8 \%$ by vol. where it 1s free; intercept of very coarse-grained pyrox. (crystals as large as $3^{\prime \prime}$ ) @ 427'-433'; zones of alteration \& moderate Practuring \& 421-422', 426', 438.5', \& 444'; minute trace of disseminated pyrite.

447.5-449.5 Pyrox., fire, porphyritic, dikelet; contains rounded, mogmatic corroded, 1/4" phenocrysts of pyroxene, serpentine pseudomorphs after olivine, \& epldote; cuts
core $\& 30^{\circ}$.

$\begin{array}{lllll}449 & 455 & 6 & 6 & 100 \\ 455 & 461 & 6 & 6 & 100 \\ 461 & 467 & 6 & 6 & 100 \\ 467 & 470 & 3 & 3 & 100 \\ 470 & 475.5 & 5.5 & 5.5 & 100 \\ & & & & \\ 475.5 & 485 & 9.5 & 9.5 & 100 \\ 485 & 488 & 3 & 3 & 100 \\ 488 & 494 & 6 & 5.5 & 90 \\ 494 & 497.5 & 3.5 & 3.5 & 100 \\ 497.5 & 505 & 7.5 & 7.5 & 100 \\ 505 & 515 & 10 & 10 & 100 \\ 515 & 519 & 4 & 4 & 100 \\ 519 & 524.5 & 5.5 & 5.5 & 100 \\ 524.5 & 535 & 10.5 & 10.5 & 100 \\ 535 & 540 & 5 & 5 & 100\end{array}$

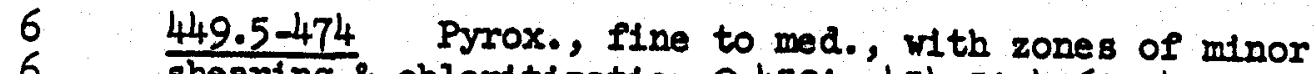
shearing \& chloritization (3 452', 454.5'-456', 459'; free magnetite av. $6 \%$ by vol.; intergrowth patches are rare.

474-540 Pyrox., coarse, with minor fracturing except for zones of shearing \& alteration ( ) 474'-475.5', 485', $487.5^{\prime}, 493.5^{\prime}, 497^{\prime}, 522^{\prime}, 526.5^{\prime}, 529^{\prime}, 538^{\prime}, 539.5^{\prime}$; shears av. $30^{\circ}$ to core; magnet1te in $1 / 4^{\prime \prime}-1$ " intergrowth patches av. $4 \%$ by vol.; gabbro dikelet (s) $497-498^{\prime}$ cuts core @ $20^{\circ}$. 
DRIIJ HOLE H-13 COnt'd

$\frac{\text { From }}{540} \frac{\text { To }}{550} \frac{\text { D1stance }}{10} \frac{\text { Core }}{10} \frac{\phi_{\text {Rec }}}{100} \frac{\text { Megn }}{6}$

540-546 Pyrox., fine to med., relatively unfractured; with free magnetite in $1 / 8^{\prime \prime}$ to $1 / 2^{\prime \prime}$ patches; av. $7 \%$ magnetite by vol.

546-550 Pyrox., very coarse, unfractured; magnetite in rare $1 / 2^{\prime \prime}$ to $l^{\prime \prime}$ intergrowth patches av. only $3 \%$ by vol.

\begin{tabular}{|c|c|c|c|c|}
\hline $\begin{array}{l}550 \\
554 \\
564 \\
566 \\
566.5 \\
574\end{array}$ & $\begin{array}{l}554 \\
564 \\
566 \\
566.5 \\
574 \\
581\end{array}$ & $\begin{array}{c}4 \\
10 \\
2 \\
0.5 \\
7.5 \\
7\end{array}$ & $\begin{array}{c}2 \\
10 \\
2 \\
0.5 \\
7.5 \\
7\end{array}$ & $\begin{array}{l}50 \\
100 \\
100 \\
100 \\
100 \\
100\end{array}$ \\
\hline $\begin{array}{l}581 \\
591 \\
594 \\
604 \\
607.5 \\
614 \\
617\end{array}$ & $\begin{array}{l}591 \\
594 \\
604 \\
607.5 \\
614 \\
617 \\
622\end{array}$ & $\begin{array}{c}10 \\
3 \\
10 \\
3.5 \\
6.5 \\
3 \\
5\end{array}$ & $\begin{array}{c}10 \\
2.5 \\
10 \\
3.5 \\
6.5 \\
3 \\
5\end{array}$ & $\begin{array}{l}100 \\
80 \\
100 \\
100 \\
100 \\
100 \\
100\end{array}$ \\
\hline $\begin{array}{l}622 \\
624 \\
626 \\
627 \cdot 5 \\
635\end{array}$ & $\begin{array}{l}624 \\
626 \\
627 \cdot 5 \\
635 \\
641\end{array}$ & $\begin{array}{l}2 \\
2 \\
1.5 \\
7.5 \\
6\end{array}$ & $\begin{array}{l}1.5 \\
1.5 \\
1.5 \\
7.5 \\
6\end{array}$ & $\begin{array}{r}75 \\
75 \\
100 \\
100 \\
100\end{array}$ \\
\hline $\begin{array}{l}641 \\
644 \\
644.5 \\
648.5 \\
650\end{array}$ & $\begin{array}{l}644 \\
644.5 \\
648.5 \\
650 \\
652.5\end{array}$ & $\begin{array}{l}3 \\
0.5 \\
4 \\
1.5 \\
2.5\end{array}$ & $\begin{array}{l}3 \\
0.5 \\
4 \\
1.5 \\
2.5\end{array}$ & $\begin{array}{l}100 \\
100 \\
100 \\
100 \\
100\end{array}$ \\
\hline
\end{tabular}

550-570 Pyrox., coarse, with magnetite in $1 / 2^{\prime \prime}$ intergrowth patches av. $4 \%$ by vol.; zones of moderate shearing \& alteration (350'-554', 559', 565'-567'; shearing av. $20^{\circ}$ to core with striations av. $70^{\circ}$; dark gray andesite dikelet ( ) 566'-566.5' cuts core \& $60^{\circ}$.

570-577 Pyrox., med., w1th rare 1/8" patches of free magnetite, av. $5 \%$ of the rock by vol.; fractured \& altered zone (c) 573.5'-574'.

577-621 Pyrox., coarse, with magnet1te in Intergrowth patches as large as 2 "; magnetite av. $4 \%$ by rol.; zones of shearing \& alteration o 580.5'-581', 593.5', 598'-600', $601^{\prime}, 607^{\prime}, 617^{\prime}-617.5^{\prime}, 619^{\prime}$; shears av. $20^{\circ}$ to core \& Btrlations av. $80^{\circ}$; dark gray andesite dikelet (s) 592'$593^{\prime}$ cuts core (3) $50^{\circ}$.

621-629 Pyrox., coarse, as above but moderately to intensely sheared, mylonized \& altered; talcose shears av. $0^{\circ}-250$ to core \& atriations av. $80^{\circ}-90^{\circ}$.

629-642 Pyrox.; coarse, relat1vely unfractured;

magnetite, mainly in intergrowth with pyroxene av. $4 \%$ by vol.; rare trace of disseminated pyrite. 642-653 Pyrox., coarse, as above but moderately sheared \& highly altered; shears av. 300 to core; numerous thin, random carbonate veinlets @ 648.5'-652.5'; dikelet of gabbro @ 644'-645'. 
DRILL HOLE H-13 Cont'd

\begin{tabular}{|c|c|c|c|c|c|c|}
\hline From & To & Distance & Core & $\begin{array}{c}\text { \% Core } \\
\text { Rec. }\end{array}$ & $\begin{array}{r}\% \\
\text { Magn. }\end{array}$ & Character of Material \\
\hline $\begin{array}{l}652.5 \\
658\end{array}$ & $\begin{array}{l}658 \\
661\end{array}$ & $\begin{array}{l}5.5 \\
3\end{array}$ & $\begin{array}{l}5.5 \\
2.5\end{array}$ & $\begin{array}{r}100 \\
80\end{array}$ & $\begin{array}{l}4 \\
4\end{array}$ & 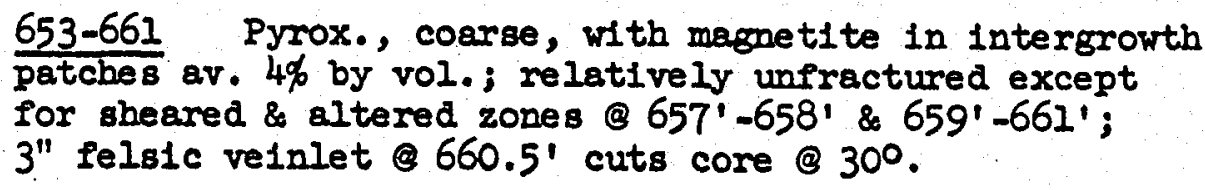 \\
\hline 661 & 664 & 3 & 2.5 & 80 & 3 & $\begin{array}{l}\text { 661-665 Diorite to monzonite dikelet, fine-grained, } \\
\text { Ifght to med. gray; chloritized along fractures \& av. } \\
\text { of } 70^{\circ} \text { to core; dikelet cuts pyrox. \& } 30^{\circ} \text {. }\end{array}$ \\
\hline 664 & 668 & 4 & 4 & 100 & 4 & $\begin{array}{l}\text { 665-668 Pyrox., med., relatively unfractured; } \\
\text { Bome Iree magnetite, but the majority } 18 \text { in } 1 / 4^{\prime \prime}-1 / 2 " \\
\text { patches of 1ntergrowth; magnetite av. } 4 \% \text { by vol. }\end{array}$ \\
\hline
\end{tabular}


Started: July 23, 1959

Completed: August 4, 1959

Elevation (collar reference $\mathrm{H}-2$ ) $=-58$ '

Located $600^{\prime}$ south and $200^{\prime}$ we st of northeast corner of $18 \mathrm{C}$

From to Distance Core $\%$ Core Rec. Magn.

$\begin{array}{rrr}0 & 10 & 10 \\ 10 & 20 & 10\end{array}$

10

$\begin{array}{lll}10 & 20 & 10\end{array}$

$\begin{array}{lll}74 & 80 & 6 \\ 80 & 90 & 10\end{array}$

$\begin{array}{lllll}\text { BX } 91 & 92.5 & 1.5 & 1.0 & 70 \\ \text { BX } 92.5 & 94 & 1.5 & 0.5 & 30 \\ \text { BX } 94 & 95 & 1.0 & 0.5 & 50 \\ \text { BX } 95 & 96.5 & 1.5 & 1.0 & 70 \\ \text { BX } 96.5 & 98.5 & 2.0 & 1.0 & 50 \\ \text { BX } 98.5 & 100 & 1.5 & 1.0 & 70 \\ \text { BX100 } & 101 & 1.0 & 0.5 & 50\end{array}$

Character of Materlal

(3-7/8" rock b1t and mud)

Gravel, pebble to sranule size.

Gravel, pebble to granule with a few cobbles.

(Strong artesian water Ilow encountered (8) 34!. Rotary drilling abandoned and hole proceeded by washing and $20-74^{\prime}$.

Gravel, pebble to cobble size

Gravel, Granule size, with a few Interbeds of sand, fine to medium; slight increase in magnetite.

(Pyroxenite ledge @ 91'). (BX-casing set to $90^{\prime}$ ).

91-101 Pyrox., med., w1th minor fracturing; magnetite is in $1 / 8^{\prime \prime}-1 / 4^{\prime \prime}$ sooty-black patches of intergrowth $1 / 8^{\prime \prime}$ disseminated $4 \%$ by vol.; considerable blotite in Q 95.5-96'. euhedral pyroxene crystals.

(AX-casing set to $100^{\prime}$ ). 
DRILL HOLE H-14 Cont'd

\begin{tabular}{|c|c|c|c|c|c|c|}
\hline From & To & Distance & Core & $\begin{array}{l}\% \text { Core } \\
\text { Rec. }\end{array}$ & Magn. & Character of Material \\
\hline $\begin{array}{l}101 \\
102\end{array}$ & $\begin{array}{l}102 \\
103\end{array}$ & $\frac{1}{1}$ & $\begin{array}{l}0.5 \\
1\end{array}$ & $\begin{array}{r}50 \\
100\end{array}$ & $\begin{array}{l}6 \\
5\end{array}$ & $\begin{array}{l}\frac{101-102.5}{8 \text { biotite as phonocrysts; av. } 6 \% \text { magnetite by vol.; is a }} \\
\text { dikelet cutting }\end{array}$ \\
\hline $\begin{array}{l}103 \\
107.5 \\
111 \\
114 \\
116.5\end{array}$ & $\begin{array}{l}107.5 \\
111 \\
214 \\
116.5 \\
120\end{array}$ & $\begin{array}{l}4.5 \\
3.5 \\
3 \\
2.5 \\
3.5\end{array}$ & $\begin{array}{l}4.5 \\
3.5 \\
2.5 \\
2 \\
3\end{array}$ & $\begin{array}{r}100 \\
100 \\
80 \\
80 \\
90\end{array}$ & $\begin{array}{l}4 \\
4 \\
4 \\
4 \\
4\end{array}$ & 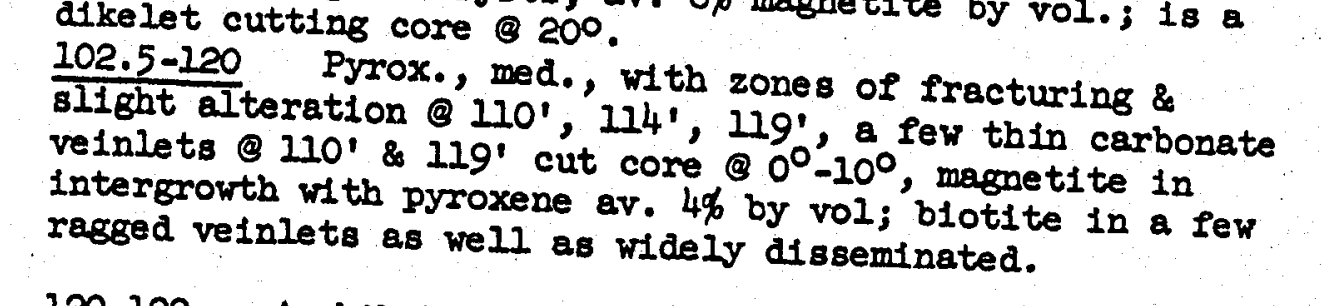 \\
\hline 120 & 122 & 2 & 2 & 100 & 6 & $\begin{array}{l}\frac{120-122}{\text { the core }} \text { Amphibole andesite, porphyritic; dikelet cuts } \\
\text { of rock; mognetite av. } 6 \% \text { by vol. }\end{array}$ \\
\hline $\begin{array}{l}122 \\
123\end{array}$ & $\begin{array}{l}123 \\
131\end{array}$ & $\frac{1}{9}$ & $\begin{array}{l}0.5 \\
2.5\end{array}$ & $\begin{array}{l}50 \\
30\end{array}$ & $\begin{array}{l}4 \\
4\end{array}$ & $\frac{122-131}{\text { fracturing } Q}$ Pyrox. $0^{\circ}-40^{\circ}$ to cod, I1ke $102.5^{\prime}-120$ '; moderate \\
\hline $\begin{array}{l}131 \\
134\end{array}$ & $\begin{array}{l}134 \\
136\end{array}$ & $\begin{array}{l}3 \\
2\end{array}$ & $\frac{1}{1.5}$ & $\begin{array}{l}30 \\
75\end{array}$ & $\begin{array}{l}6 \\
6\end{array}$ & 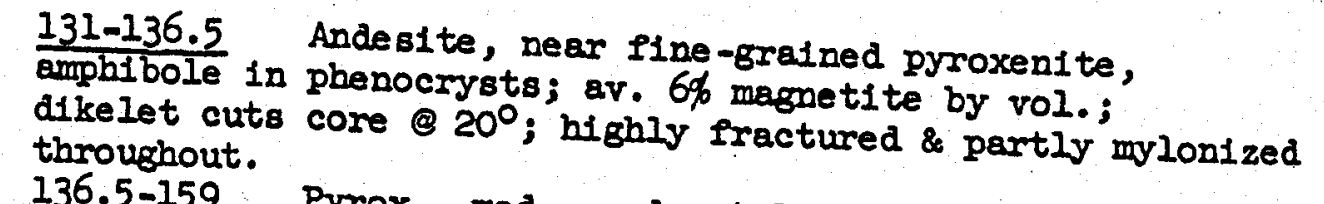 \\
\hline $\begin{array}{l}136 \\
137 \\
140 \\
141 \\
142 \\
144.5 \\
148 \\
151 \\
154.5 \\
157\end{array}$ & $\begin{array}{l}137 \\
140 \\
141 \\
142 \\
144.5 \\
148 \\
151 \\
154.5 \\
157 \\
158.5\end{array}$ & $\begin{array}{l}1 \\
3 \\
1 \\
1 \\
2.5 \\
3.5 \\
3 \\
3.5 \\
2.5 \\
1.5\end{array}$ & $\begin{array}{l}1 \\
2.5 \\
0.5 \\
1 \\
2 \\
3 \\
3 \\
3.5 \\
2.5 \\
1.5\end{array}$ & $\begin{array}{r}100 \\
80 \\
50 \\
100 \\
80 \\
85 \\
100 \\
100 \\
100 \\
100\end{array}$ & $\begin{array}{l}4 \\
4 \\
4 \\
4 \\
4 \\
4 \\
4 \\
4 \\
4 \\
4\end{array}$ & $\begin{array}{l}136.5-159 \text { Pyrox., med., moderately to intensely } \\
\text { fractured with minor shearing av. } 10^{\circ}-30^{\circ} \text { to core; } \\
\text { moderate chloritization \& a few associated velnlets of } \\
\text { carbonate \& epidote; magnetite in intergrowth with pyroxene } \\
\text { av. } 4 \% \text { by vol.; a few patches ofamplbole-blotite-felsics. }\end{array}$ \\
\hline $\begin{array}{l}158.5 \\
162.5\end{array}$ & $\frac{162.5}{168}$ & $\begin{array}{l}4 \\
5.5\end{array}$ & $\begin{array}{l}4 \\
5 \cdot 5\end{array}$ & $\begin{array}{l}100 \\
100\end{array}$ & $\begin{array}{l}4 \\
4\end{array}$ & 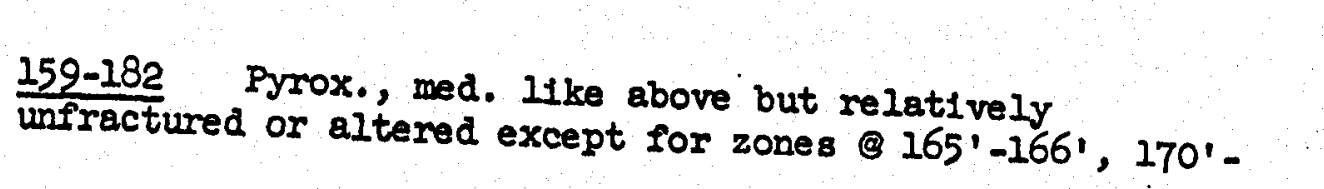 \\
\hline
\end{tabular}




\begin{tabular}{|c|c|c|c|c|c|c|}
\hline From & To & Distance & Core & $\begin{array}{c}\text { \% Core } \\
\text { Rec. }\end{array}$ & $\begin{array}{c}\% \\
\text { Magn. }\end{array}$ & Character of Materlal \\
\hline $\begin{array}{l}168 \\
170.5 \\
175.5 \\
178.5 \\
182.5 \\
183.5 \\
184.5 \\
188.5 \\
190.5 \\
195 \\
205 \\
214 \\
216 \\
221\end{array}$ & $\begin{array}{l}170.5 \\
175.5 \\
178.5 \\
182.5 \\
183.5 \\
184.5 \\
188.5 \\
190.5 \\
195 \\
205 \\
214 \\
216 \\
221 \\
224\end{array}$ & $\begin{array}{l}2.5 \\
5 \\
3 \\
4 \\
1 \\
1 \\
4 \\
2 \\
4.5 \\
10 \\
9 \\
2 \\
5 \\
3\end{array}$ & $\begin{array}{l}2.5 \\
5 \\
3 \\
4 \\
0.5 \\
0.5 \\
2 \\
2 \\
2.5 \\
9.5 \\
9 \\
1.5 \\
3.5 \\
1.5\end{array}$ & $\begin{array}{r}100 \\
100 \\
100 \\
100 \\
50 \\
50 \\
50 \\
100 \\
55 \\
95 \\
100 \\
75 \\
70 \\
50\end{array}$ & $\begin{array}{l}4 \\
4 \\
4 \\
4 \\
4 \\
4 \\
4 \\
4 \\
4 \\
4 \\
4 \\
4 \\
4 \\
4\end{array}$ & 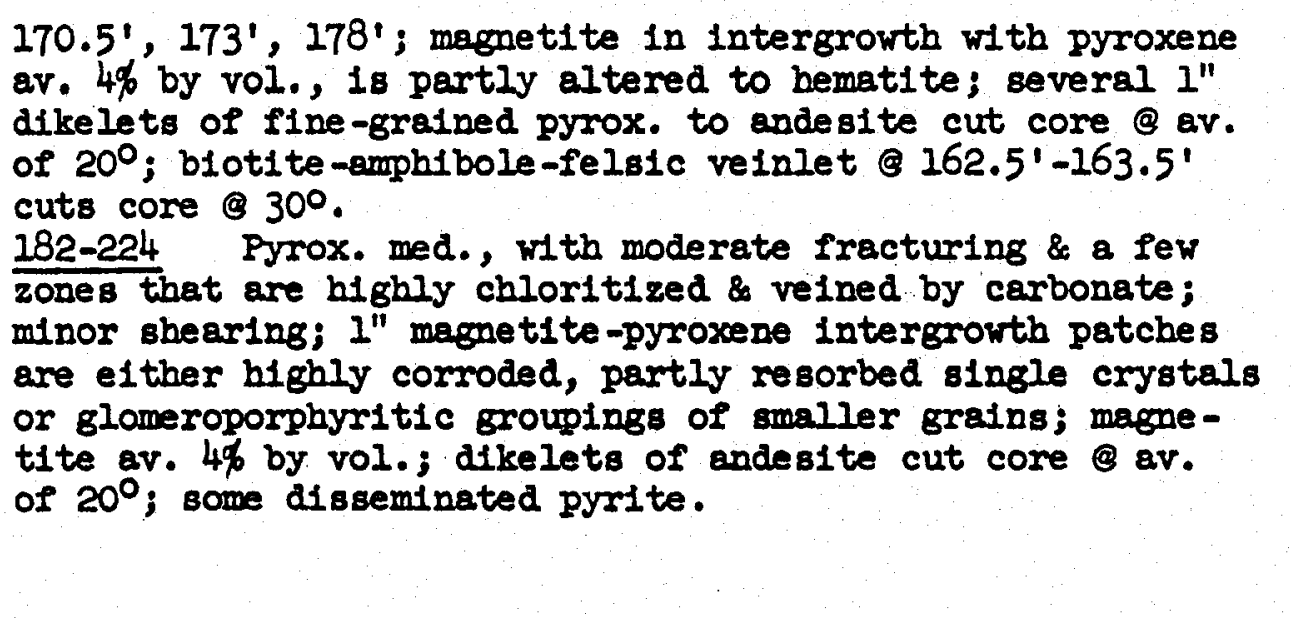 \\
\hline $\begin{array}{l}224 \\
233.5 \\
237.5\end{array}$ & $\begin{array}{l}233 \cdot 5 \\
237 \cdot 5 \\
240\end{array}$ & $\begin{array}{l}9.5 \\
4 \\
2.5\end{array}$ & $\begin{array}{l}9 \cdot 5 \\
4 \\
2\end{array}$ & $\begin{array}{r}100 \\
100 \\
80\end{array}$ & $\begin{array}{l}5 \\
5 \\
5\end{array}$ & 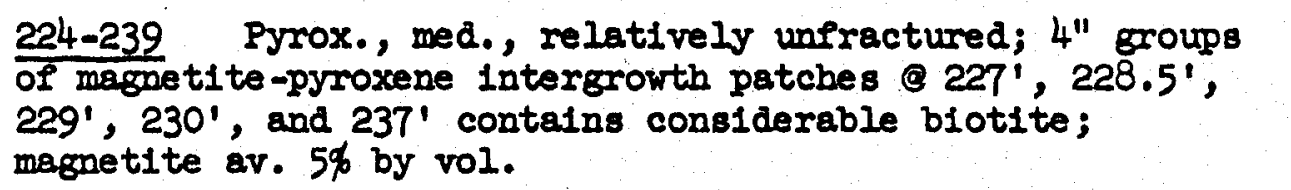 \\
\hline $\begin{array}{l}240 \\
243 \\
244 \\
247 \\
249 \\
251 \\
253 \\
255 \\
256.5 \\
257.5 \\
261.5 \\
264 \\
273.5 \\
278\end{array}$ & $\begin{array}{l}243 \\
244 \\
247 \\
249 \\
251 \\
253 \\
255 \\
256.5 \\
257.5 \\
261.5 \\
264 \\
273.5 \\
278 \\
280.5\end{array}$ & $\begin{array}{l}3 \\
1 \\
3 \\
2 \\
2 \\
2 \\
2 \\
1.5 \\
1 \\
4 \\
2.5 \\
9.5 \\
4.5 \\
2.5\end{array}$ & $\begin{array}{l}3 \\
1 \\
1 \\
1.5 \\
2 \\
1.5 \\
2 \\
1 \\
1 \\
1 \\
2 \\
7.5 \\
4 \\
2.5\end{array}$ & $\begin{array}{r}100 \\
100 \\
30 \\
75 \\
100 \\
75 \\
100 \\
70 \\
100 \\
25 \\
80 \\
80 \\
90 \\
100\end{array}$ & $\begin{array}{l}4 \\
3 \\
4 \\
4 \\
4 \\
4 \\
3 \\
4 \\
3 \\
4 \\
4 \\
4 \\
4 \\
4\end{array}$ & $\begin{array}{l}\text { 239-259.5 Pyrox., med., like above but bighly fractured } \\
\text { altered with several zones of intense shearlng \& } \\
\text { mylonization; shears av. } 20^{\circ}-30^{\circ} \text { to core with striations } \\
\text { av. } 700 \text {; minor pyrite is disseminated \& along fractures. }\end{array}$ \\
\hline GMC & A REPO & 355 & & & & Page $136 / 189$ \\
\hline
\end{tabular}


DRILI. HOLE H-14 COnt'd

\begin{tabular}{|c|c|c|c|c|c|}
\hline From & To & Distance & Core & $\begin{array}{l}\text { \% Core } \\
\text { Rec. }\end{array}$ & $\begin{array}{c}\% \\
\text { Magn }\end{array}$ \\
\hline $\begin{array}{l}280.5 \\
285 \\
286 \\
290 \\
293 \\
295 \\
297\end{array}$ & $\begin{array}{l}285 \\
286 \\
290 \\
293 \\
295 \\
297 \\
300\end{array}$ & $\begin{array}{l}4.5 \\
1 \\
4 \\
3 \\
2 \\
2 \\
3\end{array}$ & $\begin{array}{l}3 \\
0.5 \\
1 \\
0.5 \\
1 \\
1 \\
0.5\end{array}$ & $\begin{array}{l}70 \\
50 \\
25 \\
20 \\
50 \\
50 \\
20\end{array}$ & $\begin{array}{l}4 \\
4 \\
4 \\
4 \\
3 \\
4 \\
3\end{array}$ \\
\hline $\begin{array}{l}300 \\
301\end{array}$ & $\begin{array}{l}301 \\
306\end{array}$ & $\begin{array}{l}1 \\
5\end{array}$ & $\frac{1}{4.5}$ & $\begin{array}{r}100 \\
90\end{array}$ & $\begin{array}{l}6 \\
5\end{array}$ \\
\hline $\begin{array}{l}306 \\
306.5\end{array}$ & $\begin{array}{l}306.5 \\
312\end{array}$ & $\begin{array}{l}0.5 \\
5.5\end{array}$ & $\begin{array}{l}0.5 \\
1\end{array}$ & $\begin{array}{r}100 \\
20\end{array}$ & $\begin{array}{l}6 \\
4\end{array}$ \\
\hline $\begin{array}{l}312 \\
314 \\
317.5 \\
319.5 \\
326 \\
336 \\
338 \\
339.5 \\
341\end{array}$ & $\begin{array}{l}314 \\
317.5 \\
319.5 \\
326 \\
336 \\
338 \\
339.5 \\
341 \\
343\end{array}$ & $\begin{array}{l}2 \\
3.5 \\
2 \\
6.5 \\
10 \\
2 \\
1.5 \\
1.5 \\
2\end{array}$ & $\begin{array}{l}1.5 \\
3 \\
0.5 \\
5 \\
3 \\
1.5 \\
1.5 \\
1.5 \\
1.5\end{array}$ & $\begin{array}{r}75 \\
85 \\
25 \\
75 \\
30 \\
75 \\
100 \\
100 \\
75\end{array}$ & $\begin{array}{l}4 \\
3 \\
4 \\
4 \\
4 \\
4 \\
4 \\
4 \\
4\end{array}$ \\
\hline $\begin{array}{l}343 \\
345.5 \\
348 \\
350\end{array}$ & $\begin{array}{l}345.5 \\
348 \\
350 \\
353.5\end{array}$ & $\begin{array}{l}2.5 \\
2.5 \\
2 \\
3.5\end{array}$ & $\begin{array}{l}2.5 \\
2.5 \\
2 \\
3\end{array}$ & $\begin{array}{r}100 \\
100 \\
100 \\
85\end{array}$ & $\begin{array}{l}4 \\
5 \\
5 \\
4\end{array}$ \\
\hline $\begin{array}{l}353.5 \\
359 \\
362 \\
367\end{array}$ & $\begin{array}{l}359 \\
362 \\
367 \\
373\end{array}$ & $\begin{array}{l}5.5 \\
3 \\
5 \\
6\end{array}$ & $\begin{array}{l}2.5 \\
1 \\
5 \\
6\end{array}$ & $\begin{array}{r}50 \\
30 \\
100 \\
100\end{array}$ & $\begin{array}{l}4 \\
4 \\
4 \\
4\end{array}$ \\
\hline
\end{tabular}

Charactex of Material

282-300 Pyrox., med., intensely sheared, mylonized \& altered, several zones are crushed to a light green powder.

300-304 Amphibole andesite,porphyrit1c; dikelet cuts core (3 $10^{0}$; a few $1 / 8^{\prime \prime}-1 / 4^{\prime \prime}$ patches of amphibole; av. $6 \%$ masnetite by vol.

304-312 Pyrox., med., highly fractured but only Blightly altered, dikelet of amphibole andesite (s 306'-307'.

312-343 Pyrox; med., like abgre but intensely sheared \& altered; talcose shears (3) $0^{\circ}-40^{\circ}$ to core (av. 150) w1th striations (3) $75^{\circ}$ to $90^{\circ}$ (av. $85^{\circ}$ ); $1 / 4^{\prime \prime}-1 / 2^{\prime \prime}$. grains of magnetite-pyroxene intergrowth (e 338' display the subhedral crystal form of the host pyroxene \& are definitely earller than surrounding magnetite-free pyroxene; magnetite is largely converted to hematite (3) 314'-317!; mylonized zone (3) $325.5^{\prime}-326^{\prime}$ contalns porphyroblastic groups of zeolite crystals; several dikelets of andesite av. $10^{\circ}$ to core.

343-355 Pyrox., med., like above but with minor eracturing \& no shearing; av. 4\% magnetite by vol.; andesite dikelets @ $347^{\prime}-347.5^{\prime}$ \& $349^{\prime}-349.5^{\prime}$ cut core (3 200, have a reaction border of amphtbole.

355-405 Pyrox., med., moderately to highly fractured \& altered; magnetite in $I^{\prime \prime}$ groups of patches of pyroxenemognetite intergrowth av. $4 \%$ of the pyrox., by vol.; the intergrowth patches invariably contain $10 \%-30 \%$ blotite;

GMC DATA REPORT 355 
DRILL HOLE H-14 Cont'd

\begin{tabular}{|c|c|c|c|c|c|c|}
\hline From & To & Distance & Core & $\begin{array}{l}\text { \% Core } \\
\text { Rec. }\end{array}$ & $\begin{array}{c}\% \\
\text { Mogn. }\end{array}$ & Character of Material \\
\hline $\begin{array}{l}373 \\
382 \\
387 \\
392 \\
398 \\
400.5\end{array}$ & $\begin{array}{l}382 \\
387 \\
392 \\
398 \\
400.5 \\
406\end{array}$ & $\begin{array}{l}9 \\
5 \\
5 \\
6 \\
2.5 \\
5.5\end{array}$ & $\begin{array}{l}4.5 \\
2.5 \\
2.5 \\
4.5 \\
1.5 \\
2 .\end{array}$ & $\begin{array}{l}50 \\
50 \\
50 \\
75 \\
60 \\
40\end{array}$ & $\begin{array}{l}4 \\
4 \\
4 \\
4 \\
4 \\
4\end{array}$ & $\begin{array}{l}\text { fractures av, } 400-500 \text { to core; dikelets of andesite } 8 \\
361.5^{\prime}-363.5^{\prime} \& 366.5^{\prime}-367.5^{\prime} \text { cut core } 20^{\circ} \text {; zones of } \\
\text { more intense chloritization } 372^{\prime}-388^{\prime} \text { and } 395^{\prime}-398^{\prime} \text {. }\end{array}$ \\
\hline $\begin{array}{l}406 \\
411 \\
415 \\
417\end{array}$ & $\begin{array}{l}417 \\
415 \\
417 \\
422\end{array}$ & $\begin{array}{l}5 \\
4 \\
2 \\
5\end{array}$ & $\begin{array}{l}4.5 \\
2.5 \\
2 \\
3.5\end{array}$ & $\begin{array}{r}90 \\
60 \\
100 \\
70\end{array}$ & $\begin{array}{l}6 \\
6 \\
6 \\
5\end{array}$ & 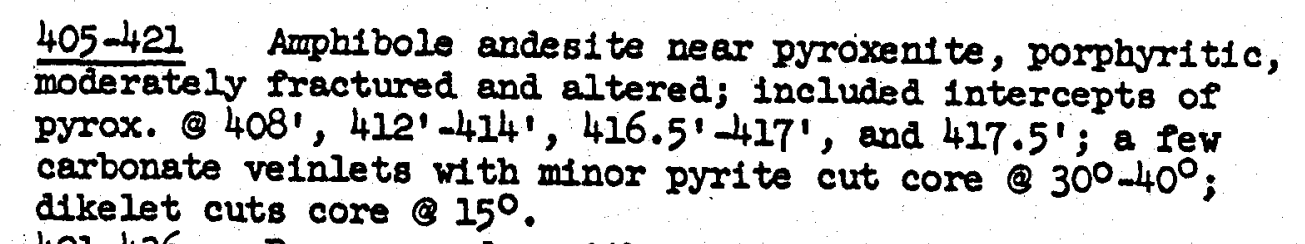 \\
\hline $\begin{array}{l}422 \\
423.5 \\
431.5\end{array}$ & $\begin{array}{l}423 \cdot 5 \\
431 \cdot 5 \\
436\end{array}$ & $\begin{array}{l}1.5 \\
8 \\
4.5\end{array}$ & $\begin{array}{l}1.5 \\
8 \\
3\end{array}$ & $\begin{array}{r}100 \\
100 \\
70\end{array}$ & $\begin{array}{l}4 \\
5 \\
4\end{array}$ & $\begin{array}{l}421-436 \text { Pyrox., med., wh minor fracturing and } \\
\text { alteration; magnetite in 1ntergrowth ar. } 4 \% \text { by vol. } \\
\text { amphibole andesite dikelets (9) } 429^{\prime}-430^{\prime} \text { and } 430.5^{\prime}-431.5^{\prime} \\
\text { cut core } 810^{\circ}-200^{\circ}\end{array}$ \\
\hline 436 & 439 & 3 & 2.5 & 80 & 6 & $\frac{436-439}{\text { cuts core }}$ Amphibole andesite dikelet, I1ke $405^{\prime}-421^{\prime}$; \\
\hline $\begin{array}{l}439 \\
445 \\
446 \\
449 \\
455 \\
458 \\
463 \\
467 \\
474 \\
479\end{array}$ & $\begin{array}{l}445 \\
446 \\
449 \\
455 \\
458 \\
463 \\
467 \\
474 \\
479 \\
484\end{array}$ & $\begin{array}{l}6 \\
1 \\
3 \\
6 \\
3 \\
5 \\
4 \\
7 \\
5 \\
5\end{array}$ & $\begin{array}{l}4 \\
0.5 \\
1.5 \\
4 \\
3 \\
2 \\
3 \\
4.5 \\
4 \\
4\end{array}$ & $\begin{array}{r}70 \\
50 \\
50 \\
70 \\
100 \\
40 \\
75 \\
65 \\
80 \\
80\end{array}$ & $\begin{array}{l}4 \\
4 \\
4 \\
5 \\
4 \\
4 \\
4 \\
4 \\
4 \\
4\end{array}$ & 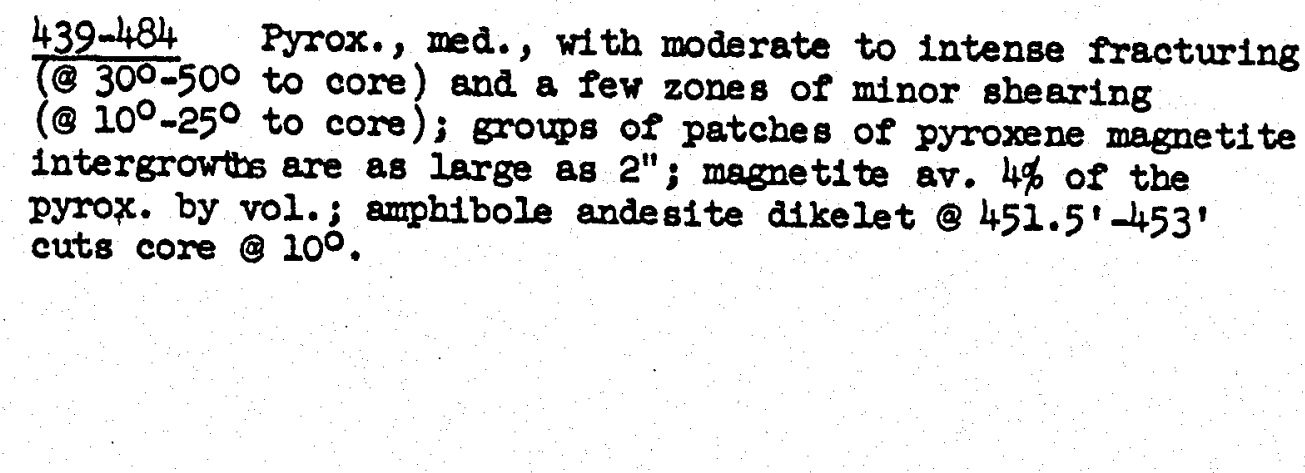 \\
\hline 484 & 486 & 2 & 2 & 100 & 6 & $\begin{array}{l}\frac{484-486.5}{\text { core @ } 200} \text { \& isphibole andesite dikelet } @ 484^{\prime}-485^{\prime} \text { cuts } \\
\text { massive andesite which cut by dikelet of med. gray, }\end{array}$ \\
\hline$D A^{\circ}$ & ORT & & & & & $\mathrm{Page} 138 / 189$ \\
\hline
\end{tabular}


DRIIC HOLE H-14 Cont'd

$\begin{array}{llllll}\text { From } & \text { To } & \text { Distance } & \text { Core } & \frac{\% \text { Core }}{\text { Rec }} & \frac{\text { Mogn. }}{486} \\ 495 & \frac{495}{500} & 5 & 5.5 & \frac{80}{4} & \frac{4}{4}\end{array}$

Character of Material

486.5-500 Pyrox., med., relat1vely unfractiured but moderately chloritized with a few velnlets of carbonate; dikelets of porphyritic amphibole andesite (s) 491'-493.5' and $499^{\prime}-500^{\prime}$ cut core @ 100; av, 4\% magnetite by vol. 
Started: July 31, 1959

Completed: August 4, 1959

Elevation (collar reference $\mathrm{H}-2$ ) $=$ \& 114

Iocated 660' south of northeast corner of claim 30

From To Distance Core Rec. \& Magn.

(4-1/4" rock bit and mad.)

No sludges taken.

Sand, fine to very Iine, light brown, minor magnetite. Sand, fine, with minor interbeds of coarse sand.

Sand, fine to med., with a few interbeds of grevel, granule-to-pebble size.

Gravel, gramule-to-pebble size, with minor sand. S1It, brown, with minor sand; slightly lignitic.

Silt and fine sand

Sand, fine

Sand, medium.

Sand, fine to medium, with minor gravel, gramule.

Silt, light gray, with laterbeds of grevel, granule. Sand, fine to med., with minor gravel, slight Increase in magnetite content.

Sand, med., with interbeds of gravel, granule to cobble Silt to fine sand, Iight to medium brown

Sand, fine; considerable increase in pyroxene and magnetite content. (Pyroxenite ledge @ 458')

(BX-casing set to $470^{\prime}$ )

470-517.5 Pyroxenite, coarse to very coarse; Intensely fractured and altered with thin, random velniets of carbonate and chlorite; magnetite is in reticulate interigrowth with pyraxene; zones (s) 471.5-472.5 and 485.5-486.5' are nearly solid pyroxene-magnetite intergrowth (?); the pyrox. av. 4\% magnet1te by vol.; kaointzed felsic velnlet (s) 489.5-490'; fracturing is random. 
DRITL HOLE H-15 Cont'd

\begin{tabular}{|c|c|c|c|c|c|}
\hline From & Io & DLstance & Core & $\begin{array}{l}\text { of Core } \\
\text { Rec. }\end{array}$ & \& Magn. \\
\hline $\begin{array}{l}510 \\
515 \\
518 \\
523 \\
528 \\
533 \\
538 \\
541 \\
545 \\
549 \\
552 \\
556.5 \\
560 \\
565 \\
568 \\
570 \\
572.5 \\
575 \\
578.5 \\
581\end{array}$ & $\begin{array}{l}515 \\
518 \\
523 \\
528 \\
533 \\
538 \\
541 \\
545 \\
549 \\
552 \\
556.5 \\
560 \\
565 \\
568 \\
570 \\
572.5 \\
575 \\
578.5 \\
581 \\
583\end{array}$ & $\begin{array}{l}5 \\
3 \\
5 \\
5 \\
5 \\
5 \\
3 \\
4 \\
4 \\
3 \\
4.5 \\
3.5 \\
5 \\
3.0 \\
2 \\
2.5 \\
2.5 \\
3.5 \\
2.5 \\
2\end{array}$ & $\begin{array}{l}0.5 \\
1.5 \\
2.5 \\
1.0 \\
0.5 \\
2.0 \\
1.0 \\
3.5 \\
1.5 \\
2.5 \\
2.5 \\
1.5 \\
3.0 \\
3.0 \\
1.0 \\
2.0 \\
1.5 \\
1.5 \\
1.5 \\
2.0\end{array}$ & $\begin{array}{r}10 \\
50 \\
50 \\
20 \\
10 \\
40 \\
30 \\
90 \\
40 \\
85 \\
55 \\
45 \\
60 \\
100 \\
50 \\
80 \\
60 \\
40 \\
60 \\
100\end{array}$ & $\begin{array}{l}4 \\
4 \\
6 \\
4 \\
4 \\
4 \\
4 \\
4 \\
4 \\
4 \\
4 \\
4 \\
4 \\
4 \\
4 \\
6 \\
6 \\
4 \\
4 \\
5\end{array}$ \\
\hline
\end{tabular}

517.5-522 Andesite dikelet, dark to med. gray, massive; altered w1th zeollte along fractures. 522-570.5 Pyroxenlte, coarse to very coarse, Intensely frectured and altered, like 470-517.5'--no apparent shearing; fewer carbonate velnlets but zones (3) $549^{\prime}$. $551.5^{\prime}$ and $561^{\prime}-567$ are intensely chloritized; @ 570!571.5' carbonate veinlets saturate the pyroxenite, following the pyroxene cleavage; magnetite in intergrowth w1th pyroxene are $4 \%$ by vol.; zone of intergrowth @ $522-523^{\prime}$.

570.5-574.5 Pyroxene-magnetite Intergrowth with: a few Included patches of magnetiterfree pyroxene; much of the sllicate in intergrowth may be amphibole and biotite rather than pyroxene.

574.5-585.5 Pyroxene, coarse, Intensely fractured but only moderately altered (chloritized; av. $4 \%$ magnetite by volume (in intergrowth $)$ ); andesite dikelet, med. gray, massive (9) 581-582.5' cuts core (3) $30^{\circ}$; felsic veinlet (B) 578.5-579' cuts core (3) 50\%; rare trace of pyrite along

$\begin{array}{llllrl}583 & 587 & 4 & 3.5 & 85 & 4 \\ 587 & 592.5 & 5.5 & 5.5 & 100 & 4 \\ 592.5 & 597.5 & 5 & 4.5 & 90 & 4\end{array}$
fractures.

585.5-598 Pyrox., med. to coarse, relatively unfractured; magnetite in intergrowth av. $4 \%$ by vol.; intergrowth occurs in irregular patches and in veinlets)?) cutting
core (Q) $40^{\circ}-70^{\circ}$.

$\begin{array}{lllll}597.5 & 602.5 & 5 & 5.0 & 100 \\ 602.5 & 604 & 1.5 & 1.5 & 100 \\ 604 & 613 & 9 & 9.0 & 100 \\ 613 & 614 & 1 & 1.0 & 100 \\ 614 & 618 & 4 & 4.0 & 100 \\ 618 & 622 & 4 & 4.0 & 100 \\ 622 & 632 & 10 & 10.0 & 100\end{array}$

598-606 Pyrox., very coarse-grained (crystals up to $2^{\prime \prime}$ ), relatively unfractured; abundant pyroxene-magnetite intergrowth (several I'core lntercepts; pyrox. av. 5\% magnetite by rol. 606-623 Pyrox., very coarse, relatively unfractured; less pyroxene-magnetite intergrowth than above; magnetite
$4 \%$ by vol. 
DRITL HOLE H-15 Cont'a

632

637
5
Character of Material

623-632 pyroxene-magnetite intergrowth with scattered patches of magnetite-free pyroxene; probably ar. about $6 \%$.magnetite by vol.; relatively unfractured.

632-634 Andesite, med. gray massive, dikelet cuts core $90^{\circ}$

634-637 Pyroxene, coarse, with moderate fracturing but only slight alteration; pyroxene-magnetite intergrowth zone () $634^{\prime}-635^{\prime}$; pyroxene av. $5 \%$ by vol. 
Started:

DRILL HOLE H-16

August 6, 1959

Elevation August 15, 1959

Located 120 (

west and $50^{\prime}$ north of south end center post of claim 37E

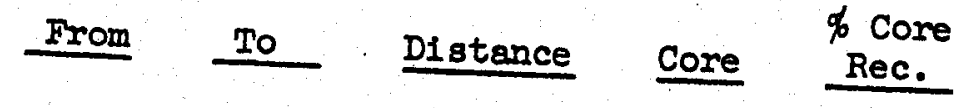

Character of Material

$\begin{array}{rrr}0 & 20 & 20 \\ 20 & 30 & 10 \\ 30 & 70 & 40 \\ 70 & 130 & 60 \\ 130 & 150 & 20 \\ 150 & 180 & 30 \\ 180 & 210 & 30\end{array}$

$\begin{array}{lll}210 & 248 & 38 \\ 248 & 260 & 12\end{array}$

$\begin{array}{lllll}256 & 261 & 5 & 0.5 & 10 \\ 261 & 266 & 5 & 0.5 & 10 \\ 266 & 271 & 5 & 1.5 & 30 \\ 271 & 276 & 5 & 0.5 & 10 \\ 276 & 281 & 5 & 0.5 & 10 \\ 281 & 286 & 5 & 0.5 & 10 \\ 286 & 291 & 5 & 0.5 & 10 \\ 291 & 296 & 5 & 0.5 & 10 \\ 296 & 297 & 1 & 0.5 & 50\end{array}$

( $37 / 8^{\prime \prime}$ rock b1t \& mud)

Silt, brown to gray.

Silt \& Pine oand

Gravel, granule to minor gravel, pebble size.

Sand, fine to

Sand, fine \& gravel, pebble

Sand, fine; minor menetite

Sand, Iine with minoretite

magnetite content (at least

(a) vol.).

Like above but with decrease in magnetite content.

Silt, light yellowlsh-brown with only a trace of magnetite.

(The argililte, first encountered \& 250!, is too weathered to and reaming.)

$256-208.5$

ilght green to tan to white in fractured \& altered (weatbered); to core $1 \mathrm{~s}$ largely mashed by alteration. beding lamination av. $10^{\circ}$ fractures are ifmonite coated. 
DRILL HOLE H-16

\begin{tabular}{llllll} 
From & To & Distance & Core & $\begin{array}{c}\text { \% Core } \\
\text { Rec. }\end{array}$ \\
\cline { 5 - 6 } & & & & & \\
297 & 300 & 3 & 2 & 70 \\
300 & 301 & 1 & 0.5 & 50 \\
301 & 303 & 2 & 0.5 & 25 \\
303 & 305.5 & 2.5 & 2 & 80
\end{tabular}

$\begin{array}{lllll}305.5 & 307.5 & 2 & 1.5 & 75 \\ 307.5 & 309 & 1.5 & 0.5 & 30 \\ 309 & 311 & 2 & 2 & 100 \\ 311 & 312 & 1 & 0.5 & 50 \\ & & & & \\ 312 & 314 & 2 & 0.5 & 25 \\ 314 & 316 & 2 & 0.5 & 25 \\ 316 & 318 & 2 & 0.5 & 25 \\ 318 & 323 & 5 & 1 & 20 \\ 323 & 325 & 2 & 0.5 & 25 \\ 325 & 329 & 4 & 0.5 & 12 \\ 329 & 332 & 3 & 0.5 & 16 \\ 332 & 335 & 3 & 1 & 30 \\ 335 & 340 & 5 & 1 & 20 \\ 340 & 345 & 5 & 0.5 & 10 \\ 345 & 350 & 5 & 0.5 & 10 \\ 350 & 355 & 5 & 0.5 & 10 \\ 355 & 360 & 5 & 0.5 & 10 \\ 360 & 364 & 4 & 0.5 & 12 \\ 364 & 370 & 6 & 0.5 & 8 \\ 370 & 372 & 2 & 0.5 & 25 \\ 372 & 376 & 4 & 0.5 & 12 \\ 376 & 382 & 6 & 1 & 16\end{array}$

Character of Material

298.5-305.5 Argillite, siliceous; moderate fracturing but only slight alteration; two main sets of fractures (e) $0^{\circ}-15^{\circ} \& 60^{\circ}-70^{\circ}$ to core; alternate reddish-brown and light gray laminations av. $10^{\circ}$ to core; redalsh-brown laminations are probably predominantly argillaceous material, possibly with some hematite; light gray laminations are probably quartzose; the argillite is also cut by numerous random, quartzose vinlets \& stringers of several generations, some of which appear chalcedonic; fractures are chlorite-coated.

305.5-308.5 Arglilite; s1liceous, highly fractured \& altered to a 11ght tan color.

308.5-312 Predominantly quartzose velnlets; 11ght sray, unfractured \& unaltered; a few lalands of redalsh-brown argililte.

312-382 Arg1lifte, s1l1ceous, intensely fractured but only slightly altered; laminated reddlsh-brown to ollve-green \& light gray; laminations av. $10 \%$ to core; quartzose veinlets are abundant (although with the poor core recovery the hard, quartzose intercepts may be selectively recovered in preference to the argillaceous intercepts); Iimonite \& chlorite along fractures; rare trace of pyrite; a few thin veinlets of carbonate \& a few of stilbite.

GMC DATA REPORT 355

Page $144 / 189$ 
DRIII HOLE H-16

\begin{tabular}{|c|c|c|c|c|}
\hline From & To & Distance & Core & $\begin{array}{l}\% \text { Core } \\
\text { Rec. }\end{array}$ \\
\hline $\begin{array}{l}382 \\
384 \\
389 \\
392 \\
396 \\
401 \\
406 \\
411 \\
416 \\
417.5 \\
424 \\
426 \\
431 \\
436 \\
441 \\
446 \\
451 \\
453 \\
460\end{array}$ & $\begin{array}{l}384 \\
389 \\
392 \\
396 \\
401 \\
406 \\
411 \\
416 \\
417.5 \\
424 \\
426 \\
431 \\
436 \\
441 \\
446 \\
451 \\
453 \\
460 \\
467\end{array}$ & $\begin{array}{l}2 \\
5 \\
3 \\
4 \\
5 \\
5 \\
5 \\
5 \\
1.5 \\
6.5 \\
2 \\
5 \\
5 \\
5 \\
5 \\
5 \\
2 \\
7 \\
7\end{array}$ & $\begin{array}{l}0.5 \\
1 \\
1 \\
1 \\
1.5 \\
0.5 \\
0.5 \\
1 \\
1 \\
1 \\
0.5 \\
0.5 \\
0.5 \\
0.5 \\
1 \\
0.5 \\
0.5 \\
0.5 \\
0.5\end{array}$ & $\begin{array}{l}25 \\
20 \\
30 \\
25 \\
30 \\
10 \\
10 \\
20 \\
70 \\
15 \\
25 \\
10 \\
10 \\
10 \\
20 \\
10 \\
25 \\
7 \\
7\end{array}$ \\
\hline $\begin{array}{l}467 \\
467.5 \\
472 \\
476 \\
483.5 \\
485 \\
489 \\
495\end{array}$ & $\begin{array}{l}467.5 \\
472 \\
476 \\
483.5 \\
485 \\
489 \\
495 \\
503\end{array}$ & $\begin{array}{l}0.5 \\
4.5 \\
4 \\
7.5 \\
1.5 \\
4 \\
6 \\
8\end{array}$ & $\begin{array}{l}0.5 \\
4.5 \\
4 \\
3 \\
1.5 \\
4 \\
6 \\
7.5\end{array}$ & $\begin{array}{r}100 \\
100 \\
100 \\
40 \\
100 \\
100 \\
100 \\
95\end{array}$ \\
\hline $\begin{array}{l}503 \\
513 \\
515 \\
521 \\
527 \\
530.5 \\
539.5\end{array}$ & $\begin{array}{l}513 \\
515 \\
521 \\
527 \\
530.5 \\
539.5 \\
543.5\end{array}$ & $\begin{array}{c}10 \\
2 \\
6 \\
6 \\
3.5 \\
9 \\
4\end{array}$ & $\begin{array}{l}6 \\
1 \\
5.5 \\
2 \\
3.5 \\
1 \\
4\end{array}$ & $\begin{array}{r}60 \\
50 \\
90 \\
30 \\
100 \\
10 \\
100\end{array}$ \\
\hline
\end{tabular}

Character of Material

382-389 Basalt or fine-gralned pyroxenite (?) dikelet; highly Practured \& chloritized; contacts with sediments not visible. 389-467 Argillite, alliceous, intensely fractured; dark brown to 8ray, laminated; laminations av. $10^{\circ}-30^{\circ}$ to core; fewer quartzose veinlets than above; numerous velnlets \& stringers of stilbite (a -40 to core \& a few velnlets of carbonate; andesite dikelet (3) 406'-406.5'; considerable chlorite along fractures; relatively cbloritized zone (s) 451'-461'.

(AX-casing set \& 467')

467-504 Argillite, 81liceous, redalsh-brown to med. gray \& quartzited (?) I1ght gray; bedding (3) 150-200 to core; quartzite (?) zones predominate; the argillaceous zones are cut by quartzose stringers usually emanating from the quartzite bands but occasionally of a later generation, cutting both; rock is relatively unfractured except for zone (8 $479^{\prime}-483.5$; rare trace of alsseminated pyrite.

504-546.5 Argillite, slilceous \& quartzite (?); relatively unfractured \& unaltered except for zones @ 504'-505', 508'-515', 519'-527', \& 530'-539'; alteration 18 primarlly to chlorite \& limonite; some zones are slightly calcareous \& zones (c) 518' \& (3) 543'-544' show partial bedding $@ 200-25^{\circ}$. 
DRILI HOLE H-16

\begin{tabular}{lllll} 
& & & & \% Core \\
From & To & Distance & Core & Rec. \\
\cline { 2 - 5 } & & & & 100 \\
543.5 & 547.5 & 4 & 4 & 40 \\
547.5 & 555.5 & 8 & 3 & 30 \\
555.5 & 558.5 & 3 & 1 & 85 \\
558.5 & 562 & 3.5 & 3 & 100 \\
562 & 568 & 6 & 6 & 90 \\
568 & 577 & 9 & 8 & 75 \\
577 & 587 & 10 & 7.5 & 12 \\
587 & 591 & 4 & 0.5 & 90 \\
591 & 595 & 4 & 3.5 & 100 \\
595 & 601 & 6 & 6 &
\end{tabular}

Character of Material

546.5-560.5 Iimestone, dense, siliceous, light gray to greenishgray with several minor included zones of siliceous argillite;

considerable recrystallization to light brown dolomite or siderite in $1 / 8^{\prime \prime}$ to $1 / 4^{\prime \prime}$ gralns.

560.5-601 Arg1llite, dark redalsh-brown, \& quartzite, l1ght gray in alternating beds cutting core (3) $15^{\circ}-20^{\circ}$; interval is predominantly quartzite; a few random velnlets of carbonate \& of zeollte; rare trace of pyrite; minor to moderate, unmineralized fracturing; $1 "$ andesite dikelet (3) 560.5' is (9) $35^{\circ}$ to core \& \& $50^{\circ}$ to the beddins of the sediments. 
DRILL HOLE H-27

Started: August 9, 1959

Completed: August 18, 1959

Elevation (collar reference $\left.\mathrm{H}_{-2}\right)=\mid 37^{\prime}$

Located at the southwest corner of claim 23K

From To D1stance Core $\begin{gathered}\text { \% Core Rec. Magn. } \\ \text { Rece }\end{gathered}$

Character of Material

(4 1/2" rock bit \& mud)

No sample.

S1lt, brown \& sand, flne; slightly lignitic.

Sand, Ilne with minor magnetite.

Band, IIne with a few interbeds of gravel (granule).

Silt, light to med. brown with minor sand, fine.

Sand, fine; conalderable increase in pyroxene, feldspar \& magnetite content.

(NX-casing set to $240^{\prime}$, but lowered with progressive drilling as intial set proved to be false ledge).

240-255 Boulders \& cobbles of pyroxentte, diorlte, monzonite, andesite \& basalt.

255-260 Cobbles \& pebbles of andesite \& pyroxente.

260-270 Boolders of pyroxenite, fine gratned.

270-280 Boulder of pyroxentte \& pebbles of all the above rock types. 
DRIIC HOLE H-17 Cont'a

\begin{tabular}{|c|c|c|c|c|c|c|}
\hline From & To & Distance & Core & $\begin{array}{l}\% \text { Core } \\
\text { Rec. } \\
\end{array}$ & \%o & Character of Material \\
\hline $\begin{array}{l}280 \\
282\end{array}$ & $\begin{array}{l}282 \\
286\end{array}$ & 2 & $\begin{array}{l}0.25 \\
0.25\end{array}$ & $\frac{12}{6}$ & & 280-286 Pebbles of chert \& basalt. \\
\hline $\begin{array}{l}286 \\
287 \\
289 \\
295\end{array}$ & $\begin{array}{l}287 \\
289 \\
295 \\
298\end{array}$ & $\begin{array}{l}1 \\
2 \\
6 \\
3\end{array}$ & $\begin{array}{l}0.25 \\
0.25 \\
0.25\end{array}$ & $\begin{array}{l}25 \\
\frac{12}{4}\end{array}$ & & $\begin{array}{l}\text { 286-298 Pebbles \& cobbles of basalt, porphyritic \& all } \\
\text { of the above rock types. }\end{array}$ \\
\hline $\begin{array}{l}298 \\
298.5 \\
303\end{array}$ & $\begin{array}{l}298.5 \\
303 \\
308\end{array}$ & $\begin{array}{l}0.5 \\
4.5 \\
5\end{array}$ & $\begin{array}{l}0.1 \\
0.1\end{array}$ & $\begin{array}{r}20 \\
2\end{array}$ & & $\begin{array}{l}\text { S1lt to flne sand, light brown to I1ght gray } \\
\text { (represented only in the sludges) with a few Included } \\
\text { cobbles \& pebbles of andesite, pyroxentte \& diorite } \\
\text { (recovered as core) }\end{array}$ \\
\hline $\begin{array}{l}308 \\
313 \\
315 \\
320\end{array}$ & $\begin{array}{l}313 \\
315 \\
320 \\
325\end{array}$ & $\begin{array}{l}5 \\
2 \\
5 \\
5\end{array}$ & 1 & 20 & & 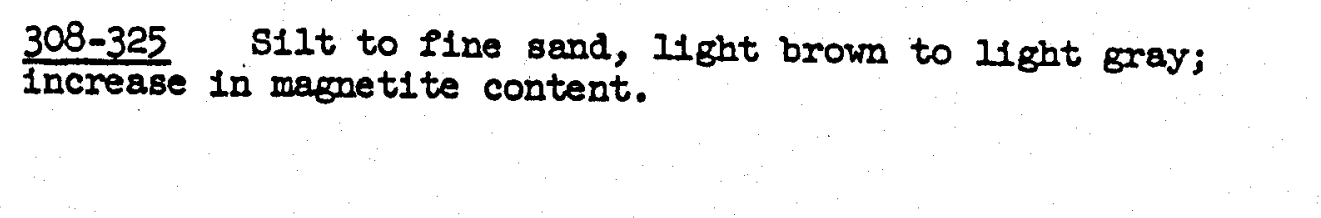 \\
\hline $\begin{array}{l}325 \\
330 \\
335 \\
340 \\
345\end{array}$ & $\begin{array}{l}330 \\
335 \\
340 \\
345 \\
350\end{array}$ & $\begin{array}{l}5 \\
5 \\
5 \\
5 \\
5\end{array}$ & $\begin{array}{l}0.25 \\
0.1 \\
0.1\end{array}$ & $\begin{array}{l}5 \\
2 \\
2\end{array}$ & & $\frac{325-350}{\text { pebbles (core) }}$ silt to fine sand (sludges) with misc. cobbles \& \\
\hline $\begin{array}{l}350 \\
355 \\
360 \\
365 \\
370\end{array}$ & $\begin{array}{l}355 \\
360 \\
365 \\
370 \\
375\end{array}$ & $\begin{array}{l}5 \\
5 \\
5 \\
5 \\
5\end{array}$ & $\begin{array}{l}1.5 \\
0.5 \\
1.5\end{array}$ & $\begin{array}{l}30 \\
10 \\
30\end{array}$ & & $\begin{array}{l}350-375 \text { S1lt to fine sand with scattered pebbles \& } \\
\text { granutes mainly of int ensely weathered pyroxenite. Several } \\
\text { zones are h1ghly carbonaceous, near peat. Sub-angular grains } \\
\text { of magnetite prob. av, about } 15 \% \text { by vol. Sludges show } \\
\text { extreme concentration of magnetite to } 50-70 \% \text {, or about } 4 \\
\text { times its true percentage. }\end{array}$ \\
\hline DATA & 380 & 10 & 6 & 60 & & $\begin{array}{l}\text { S11t, carbonaceous, near peat, dark redalsh-brown } \\
\text { to black in color; compaction laminations \& few red bands } \\
\text { of more ferruglnous silt cut core } 90^{\circ} \text {; some plant fragments } \\
\text { vistble. } \\
\text { Page } 148 / 189\end{array}$ \\
\hline
\end{tabular}


DRIIC HOLE H-17

\begin{tabular}{|c|c|c|c|c|c|c|}
\hline From & To & Distance & Core & $\begin{array}{l}\text { of Core } \\
\text { Rec. }\end{array}$ & Mogn. & Character of Material \\
\hline $\begin{array}{l}380 \\
385\end{array}$ & $\begin{array}{l}385 \\
390\end{array}$ & $\begin{array}{l}5 \\
5\end{array}$ & $\begin{array}{l}4.5 \\
2.5\end{array}$ & $\begin{array}{l}80 \\
50\end{array}$ & & $\begin{array}{l}\frac{382-389}{\text { pyroxenite \& rare pebbles of diorite \& pyroxen1te; greenlsh- }} \\
\text { gray but 1ncreasingly reddish (more ferruginous?) with } \\
\text { depth. }\end{array}$ \\
\hline $\begin{array}{l}390 \\
395 \\
400 \\
405\end{array}$ & $\begin{array}{l}395 \\
400 \\
405 \\
410\end{array}$ & $\begin{array}{l}5 \\
5 \\
5 \\
5\end{array}$ & $\begin{array}{l}1 \\
2.5 \\
3 \\
1\end{array}$ & $\begin{array}{l}20 \\
50 \\
60 \\
20\end{array}$ & & $\begin{array}{l}\text { S89-410 S1lt, sand \& pebbles, poorly sorted \& poorly } \\
\text { consolidated, reddish-brown, hlghly ferruginous \& somewhat } \\
\text { carbonaceous; identiflable sand grains \& pebbles are } \\
\text { predominantly pyroxentte. }\end{array}$ \\
\hline $\begin{array}{l}410 \\
415 \\
420\end{array}$ & $\begin{array}{l}415 \\
420 \\
425\end{array}$ & $\begin{array}{l}5 \\
5 \\
5\end{array}$ & $\begin{array}{l}0.25 \\
0.25 \\
0.1\end{array}$ & $\begin{array}{l}5 \\
5 \\
2\end{array}$ & & $\begin{array}{l}410-425 \text { Cobbles of pyroxentte \& a flne-grained sandstone } \\
\text { consisting of grains of pyroxene in a calcareous-arg12la- } \\
\text { ceous matrix. }\end{array}$ \\
\hline $\begin{array}{l}425 \\
430 \\
435 \\
440 \\
445 \\
450 \\
455\end{array}$ & $\begin{array}{l}430 \\
435 \\
440 \\
445 \\
450 \\
455 \\
460\end{array}$ & $\begin{array}{l}5 \\
5 \\
5 \\
5 \\
5 \\
5 \\
5\end{array}$ & & & & $\begin{array}{l}\frac{425-460}{\text { magnetite. Pludges are mainly of pyroxene with about } 10 \%} \\
\text { derlved from the pyroxenlte, with pyroxentte ledge (c) } 460^{\prime} \text {. }\end{array}$ \\
\hline $\begin{array}{l}460 \\
470\end{array}$ & $\begin{array}{l}470 \\
480\end{array}$ & $\begin{array}{l}10 \\
10\end{array}$ & $\begin{array}{l}0.5 \\
0.1\end{array}$ & $\begin{array}{l}5 \\
1\end{array}$ & $\begin{array}{l}7 \\
7\end{array}$ & $\begin{array}{l}460-480 \\
\text { scattered euhedral to subhedral crystals of plagloclase \& } \\
\text { amphibole. } \\
\text { (BX-casing set to } 480^{\prime} \text { ) }\end{array}$ \\
\hline $\begin{array}{l}480 \\
485 \\
490\end{array}$ & $\begin{array}{l}485 \\
490 \\
495\end{array}$ & $\begin{array}{l}5 \\
5 \\
5\end{array}$ & 0.1 & 2 & 7 & $\begin{array}{l}\text { 480-495 Pyroxentte, 11ne, 11montte-coated fractures av. } \\
300 \text { to core; magnetite av. } 7 \% \text { by vol. }\end{array}$ \\
\hline $\begin{array}{l}495 \\
500 \\
510 \\
515\end{array}$ & $\begin{array}{l}500 \\
505 \\
515 \\
520\end{array}$ & $\begin{array}{l}5 \\
5 \\
5 \\
5\end{array}$ & 0.1 & 2 & 7 & $\begin{array}{l}\frac{495-520}{\text { amphibole \& blotite; magnetite ar. } 7 \% \text { by vol. }} \\
\left.\text { (AX-casing Bet to } 520^{\prime}\right)\end{array}$ \\
\hline CDA & $v$ & & & & & Page $149 / 189$ \\
\hline
\end{tabular}


DRILL HOLE H-17

\begin{tabular}{|c|c|c|c|c|c|c|}
\hline From & To & Distance & Core & $\begin{array}{c}\text { \% Core } \\
\text { Rec. } \\
\end{array}$ & $\begin{array}{c}\% \\
\text { Magn. }\end{array}$ & Character of Materlal \\
\hline $\begin{array}{l}380 \\
385\end{array}$ & $\begin{array}{l}385 \\
390\end{array}$ & $\begin{array}{l}5 \\
5\end{array}$ & $\begin{array}{l}4 \\
2.5\end{array}$ & $\begin{array}{l}80 \\
50\end{array}$ & & $\begin{array}{l}\frac{382-389}{\text { pyroxentte \& rare pebbles of diorite \& pyroxentte; greenish- }} \\
\text { gray but increasingly reddish (more ferruginous?) with } \\
\text { depth. }\end{array}$ \\
\hline $\begin{array}{l}390 \\
395 \\
400 \\
405\end{array}$ & $\begin{array}{l}395 \\
400 \\
405 \\
410\end{array}$ & $\begin{array}{l}5 \\
5 \\
5 \\
5\end{array}$ & $\begin{array}{l}1 \\
2.5 \\
3 \\
1\end{array}$ & $\begin{array}{l}20 \\
50 \\
60 \\
20\end{array}$ & & 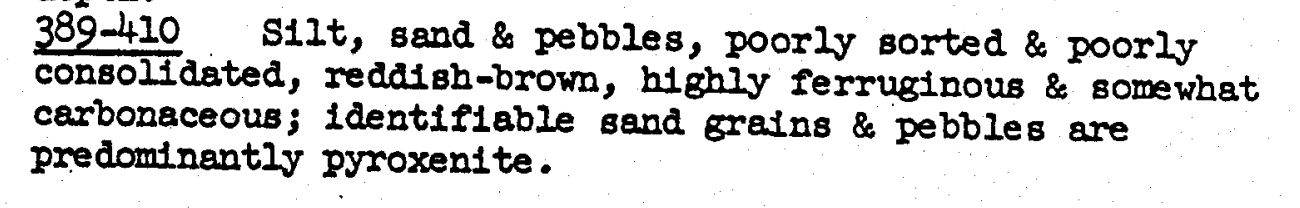 \\
\hline $\begin{array}{l}410 \\
415 \\
420\end{array}$ & $\begin{array}{l}415 \\
420 \\
425\end{array}$ & $\begin{array}{l}5 \\
5 \\
5\end{array}$ & $\begin{array}{l}0.25 \\
0.25 \\
0.1\end{array}$ & $\begin{array}{l}5 \\
5 \\
2\end{array}$ & & $\begin{array}{l}\frac{410-425}{\text { Consisting of grains of pyroxene in a calcareous-argilla- }} \\
\text { ceous matrix. }\end{array}$ \\
\hline $\begin{array}{l}425 \\
430 \\
435 \\
440 \\
445 \\
450 \\
455\end{array}$ & $\begin{array}{l}430 \\
435 \\
440 \\
445 \\
450 \\
455 \\
460\end{array}$ & $\begin{array}{l}5 \\
5 \\
5 \\
5 \\
5 \\
5 \\
5\end{array}$ & & & & $\begin{array}{l}\frac{425-460}{\text { magnetite. Pludges are mainly of pyroxene with about } 10 \%} \\
\text { derived from the pyroxenite, with pyroxenite ledge @ } 460^{\prime} \text {. }\end{array}$ \\
\hline $\begin{array}{l}460 \\
470\end{array}$ & $\begin{array}{l}470 \\
480\end{array}$ & $\begin{array}{l}10 \\
10\end{array}$ & $\begin{array}{l}0.5 \\
0.1\end{array}$ & $\begin{array}{l}5 \\
2\end{array}$ & $\begin{array}{l}7 \\
7\end{array}$ & $\begin{array}{l}460-480 \\
\text { scattered euhedral to subhedral crystals of plagloclase } 8 \\
\text { amphibole. } \\
\text { (BX-casing set to } 480^{\prime} \text { ) }\end{array}$ \\
\hline $\begin{array}{l}480 \\
485 \\
490\end{array}$ & $\begin{array}{l}485 \\
490 \\
495\end{array}$ & $\begin{array}{l}5 \\
5 \\
5\end{array}$ & 0.1 & 2 & 7 & $\frac{480-495}{300 \text { to core; magnetite av. } 7 \% \text { by vol. }}$. \\
\hline $\begin{array}{l}495 \\
500 \\
510 \\
515\end{array}$ & $\begin{array}{l}500 \\
505 \\
515 \\
520\end{array}$ & $\begin{array}{l}5 \\
5 \\
5 \\
5\end{array}$ & 0.1 & 2 & 7 & $\begin{array}{l}\frac{495-520}{\text { amphibole \& blotite; magnetite ar. } 7 \% \text { by vol. }} \\
\text { (AX-casing set to 520') }\end{array}$ \\
\hline
\end{tabular}


DRILI HOTE H-17

From $\frac{\text { To }}{530} \frac{\text { Distance }}{10} \frac{\text { Core }}{2} \frac{\begin{array}{c}\text { \% Core } \\ \text { Rec. }\end{array} \frac{\text { Mogn. }}{20}}{7}$

GMC DATA REPORT 355
Character of Mater1al

520-530 Pyrox., fine, moderate to Intense fracturing with a few talcose shears 9 av. of $30^{\circ}$ to core; considerable ampibole \& biotite; magnetite av. $7 \%$ by rol. 


\author{
A P P E N I X B \\ ASSAY AND CONCENTRATION TEST RESULTS FROM
}

H. T. CADDY LABORATORY

GMC DATA REPORT 355 


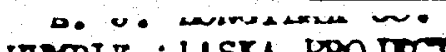

HURCIL i LASKA PPOJSCT

DRIUL HOLS NO. 7

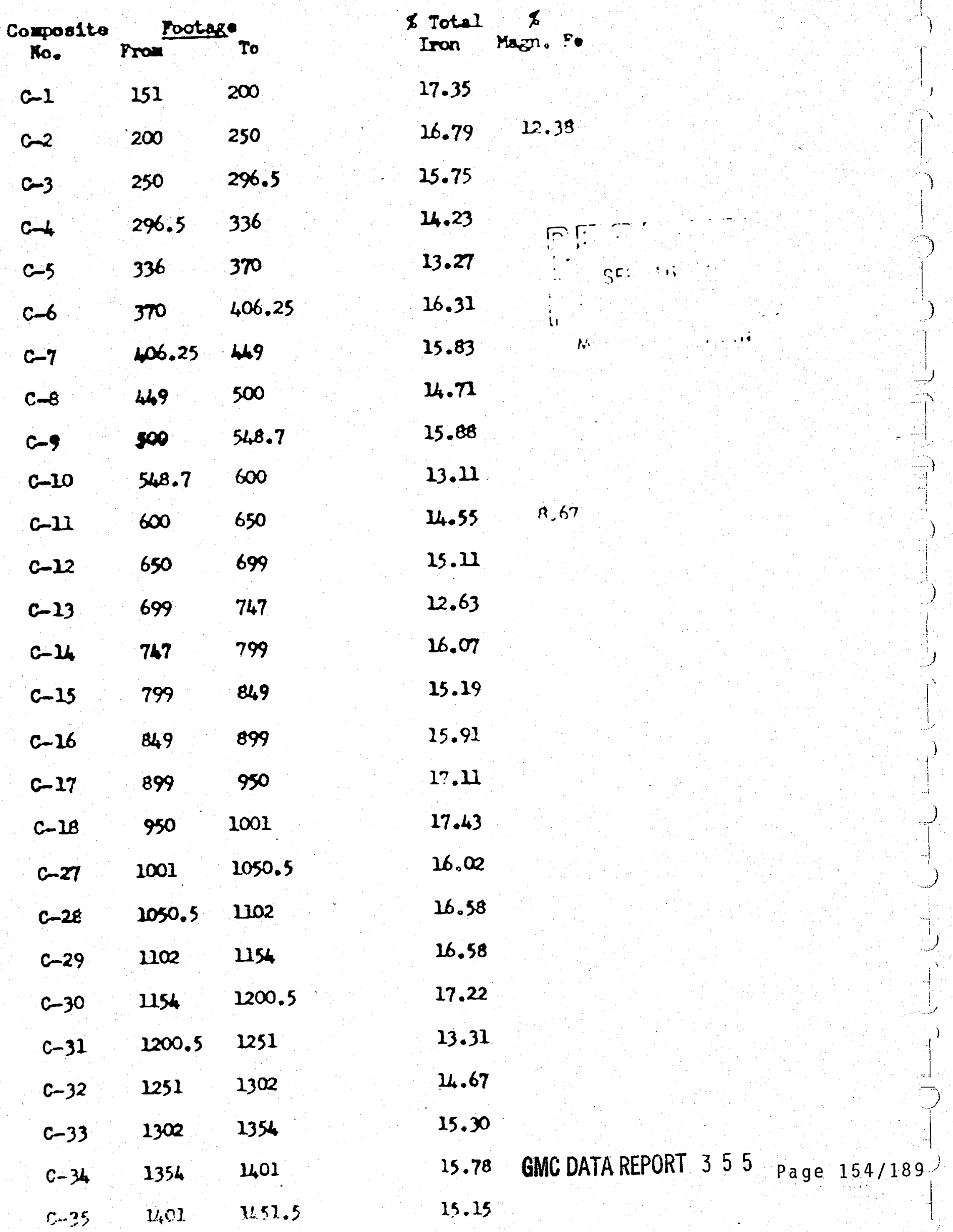


J. J. Loviten $\infty$.

Sheat 2 of 2

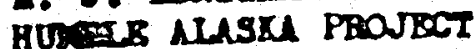

DAIL HOLE W. 7

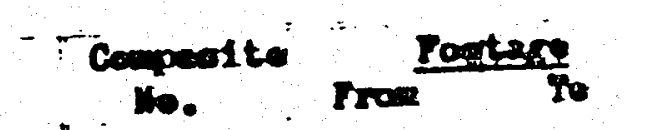

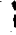

$\therefore \quad-36 \quad 451.51502$

$0-57 \quad 2500 \quad 1551$

c-36 $1551 \quad 1602$

c-39 $1602 \quad 1652.5$

c-40 $\quad 1652.5 \quad 1701$

CHI $1702 \cdot 1750$

c-42 1750: 1799.

$\begin{array}{lll}0-43 \quad 179 & 1851.5\end{array}$

cuth $2851.5 \quad 1900.5$

C-45 $1900.5 \quad 1950$

$0-1950 \quad 2000$

DRD OR BOL

Seppe

Noe

9

28
$281.5 \quad 284$

$235.5 \quad 238.5$
$\frac{X}{T}$ Total Inan Megn. Fo

15.30

15.78

15.22

14.67

15.78

15.46

16.42

16.26

16.18

16.02

$16.42 \quad 11.10$
$18.54 \quad 13.93$

$18.06 \quad 24.04$ 
A. A: langroser Co.

Huble Nlaxio Projoot

Dril1 Hol. Ho. 7 - Copper asano

samplo

- No.

505

sor

508

509

600

623

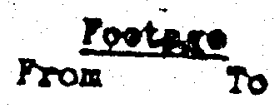

$1744 \quad 1746.5$

$1746.5 \quad 2750$

$1750 \quad 1752$

$2752 \quad 1756.5$

$1756.5 \quad 1759$

$1820.5 \quad 1825$

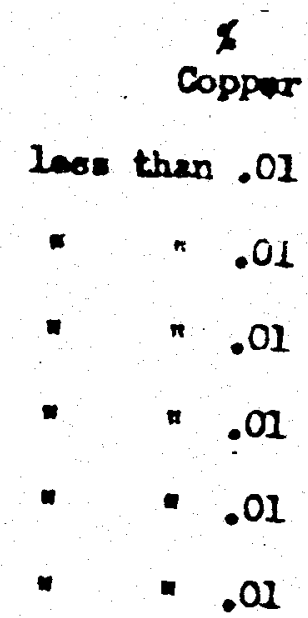




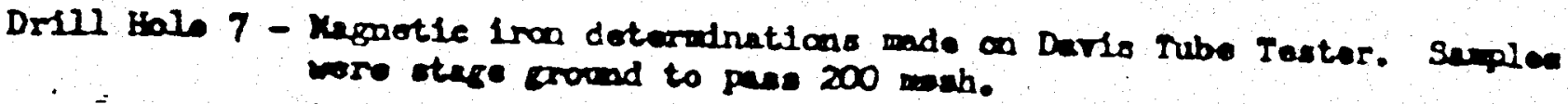

$\div$

Ins Hor

Boodingt

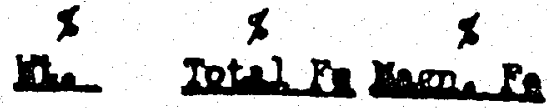

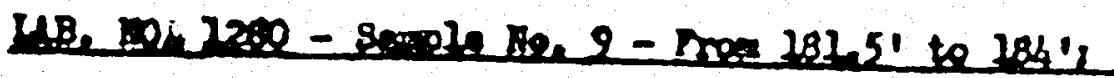

2000h-1 -200: crode

2 Magetis exounternto

$100.00 \quad 18.54$

3 troomas. tolls

$21.05 \quad 66.18$

13.93

$78.95 \quad 5.84$

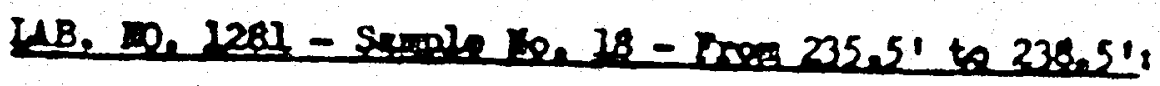

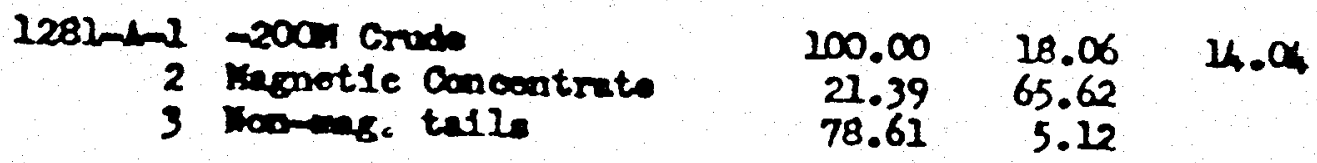

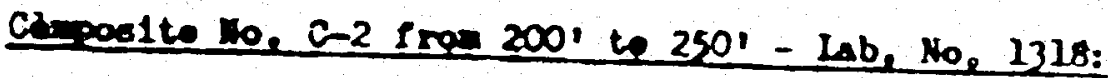

\begin{tabular}{|c|c|c|c|}
\hline $\begin{array}{l}2 \\
3\end{array}$ & $\begin{array}{l}-200 \text { Crado } \\
\text { Magnotie concentrate } \\
\text { Non-menotic lallo }\end{array}$ & $\begin{array}{c}100.00 \\
18.94 \\
81.06\end{array}$ & $\begin{array}{r}16.79 \\
65.38 \\
5.44\end{array}$ \\
\hline
\end{tabular}

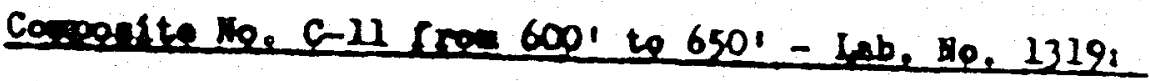

1329-1-1 -2000 crede

2 Menetic concentrate

$100.00 \quad 14.55$

$13.32 \quad 65.06$

3 Mon-m 8 . teilo

$86.68 \quad 6.79$

8.67

Coposite Ho, Cd6 rron 1950' to 20001 - Lab, No, 13201

\begin{tabular}{|c|c|c|c|}
\hline & & & \\
\hline $\begin{array}{r}2320-1 \\
2 \\
3\end{array}$ & $\begin{array}{l}-200 x \text { Crode } \\
\text { Magotic oancentrato } \\
\text { Man-m. tall }\end{array}$ & $\begin{array}{r}100.00 \\
16.73 \\
83.27\end{array}$ & $\begin{array}{r}16.42 \\
66.34 \\
6.39\end{array}$ \\
\hline
\end{tabular}


E. J. Lasesear bo.
Humblo Nlaska Project

DRIII HOIB 3P. 6

Composite Troo $\frac{\text { Pootage }}{\text { No }}$
No. Tow

$\begin{array}{lll}C-19 & 222\end{array}$

$\begin{array}{lll}C-20 & 251 & 300\end{array}$

$\begin{array}{lll}C-21 & 300 \quad 350\end{array}$

$\begin{array}{lll}C-22 & 350 \quad 402\end{array}$

$\begin{array}{lll}C-23 & 402 \quad 454\end{array}$

$\begin{array}{lll}6-24 & 454 \quad 500\end{array}$

$\begin{array}{lll}6-25 & 500 & 550\end{array}$

$\begin{array}{lll}c 26 & 550 \quad 57 t . S\end{array}$

Erid of Hole
\% Total Kaga. Fo
Irar Kag

26.79

16. Eu 12.14

15.99

15.83

23.29

11.95

$15.12 \quad 10.88$

19.37

Sample to.

$\begin{array}{lllll}229 & 222 & 224 & 20.51 & 15.69 \\ 243 & 300 & 324 & 10.28 & 14.50 \\ 253 & 339.5 & 340 & 17.08 & 12.08 \\ 257-8 & 351.5 & 385 & 12.52 & 14.27 \\ 272 & 435.5 & 437.5 & 15.50 & 3.06 \\ 300 & 535 & 538 & 12.49 & 14.24\end{array}$


8. J. Lanģear Co.

Kumble Nlaske Project

Dr1ll hole 8 - Copper assaro

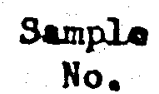

224

225

226

227

228

229

230

231

232

233

234

235

Fros $\frac{\text { Footsge }}{\text { To }}$

$222 \quad 224$

$224 \quad 228$

$228 \quad 235$

$235 \quad 245$

$245 \quad 246$

$246 \quad 251$

$251 \quad 254$

$254 \quad 257$

$257 \quad 259$

$259 \quad 264$

$264 \quad 266.5$

$266.5 \quad 271$ $\not{6}$
Copror

.02

.01

.04

Loss than .01

Less then .01

Loss than .01

Loss than .Cl

Los than .01

Lees than .01

.02

.01

.03 
Humbio Nlank Projact

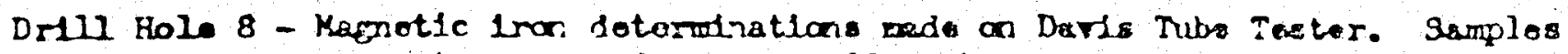
vero stage Eroumd to pasa 200 ench.

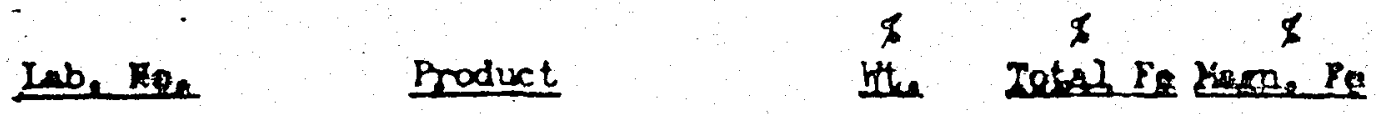

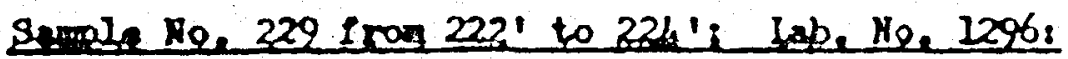

$\begin{array}{rrrrr}1296-1-1 & -200 \text { Crude } & 100.00 & 20.51 & 15.69 \\ 2 & 23.66 & 66.33 & \\ 3 & \text { Non-atic conemt reto } & 75.34 & 6.31 & \end{array}$

Sesple No, 243 froo 300 ' te 304'; Lab, Ho, 1297 :

$\begin{array}{rrrrr}1297-1-1 & -2004 \text { Crude } & 100.00 & 18.28 & 14.50 \\ 2 & \text { Magnotic concentrat. } & 22.34 & 64.90 & \\ 3 & \text { Nan- talle } & 77.66 & 4.87 & \end{array}$

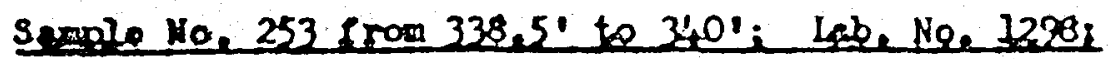

\begin{tabular}{|c|c|c|c|}
\hline $\begin{array}{r}1298-1-1 \\
2 \\
3\end{array}$ & $\begin{array}{l}2000 \text { crude } \\
\text { Monotic concentreto } \\
\text { Man-mag. tells }\end{array}$ & $\begin{array}{r}100.00 \\
17.68 \\
82.32\end{array}$ & $\begin{array}{r}17.08 \\
68.33 \\
6.07\end{array}$ \\
\hline
\end{tabular}

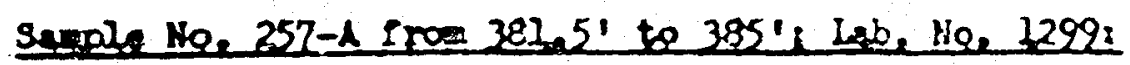

\begin{tabular}{|c|c|c|c|}
\hline $\begin{array}{r}1299+-1 \\
2 \\
3\end{array}$ & $\begin{array}{l}\text {-200x Crode } \\
\text { Magnetic ooncentrate } \\
\text { Nan-mag. talls }\end{array}$ & $\begin{array}{r}100.00 \\
21.64 \\
78.36\end{array}$ & $\begin{array}{r}18.52 \\
65.93 \\
5.43\end{array}$ \\
\hline
\end{tabular}

Sanple No, 272 r $\operatorname{ran} 435.51$ to 437.5 's Leb, No, 1300 :

\begin{tabular}{|c|c|c|c|}
\hline $\begin{array}{r}1300-1 \\
2 \\
3\end{array}$ & $\begin{array}{l}\text {-200a crode } \\
\text { Hagnetic concentrate } \\
\text { lan-ag. teills }\end{array}$ & $\begin{array}{r}100.00 \\
11.85 \\
88.15\end{array}$ & $\begin{array}{r}15.80 \\
68.01 \\
8.78\end{array}$ \\
\hline
\end{tabular}

Sample tor 300 fron 535 ' to $538^{\prime}$; Labe io, $1301 \%$

$\begin{array}{rlrrr}1301-1-1 & 200 \text { Crude } & 100.00 & 18.49 & 14.24 \\ 2 & 21.63 & 65.84 & \\ 3 & 78.37 & 5.42 & \end{array}$

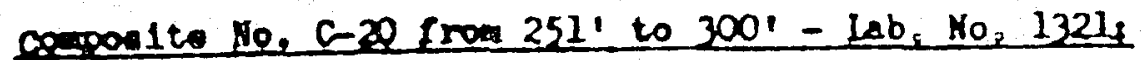

$\begin{array}{rlccc}1321-1-1 & \text {-2001 Crude } & 100.00 & 16.84 & 12.14 \\ 2 & \text { Monetic ooncontrat. } & 18.34 & 66.18 & \\ 3 & \text { Non-mas. talls } & 81.66 & 5.76\end{array}$

Compaste No, C-25 Irom 500 ' to 5501 - Lab, No, 1322:

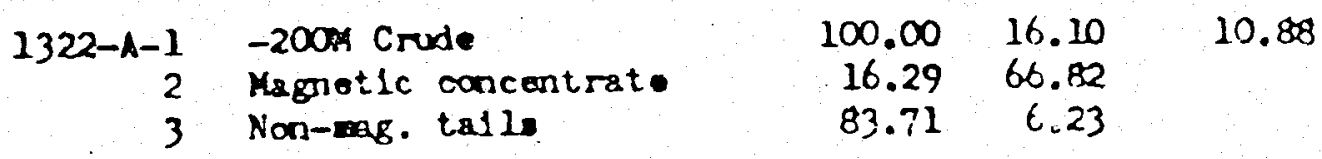


uingi

YUNGLE ALASRA PRL.JSCT

Shrot 1 of 2

DRILL HOLS NO. 9-Total Iron Assars

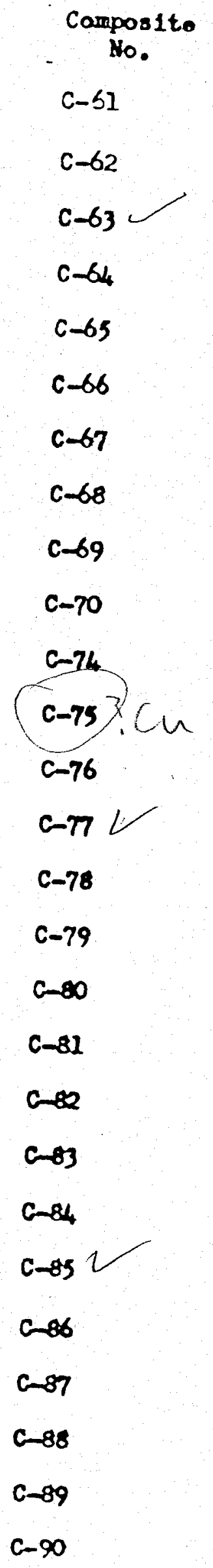

Fron Tootage

$230 \quad 250$

$250 \quad 299$

$299 \quad 350.5$

$350.5 \quad 398$

$398 \quad 454.5$

$454.5 \quad 497$

$497 \quad 546.5$

$546.5 \quad 603.5$

$603.5 \quad 650$

$650 \quad 697$

$697 \quad 748$

$748 \quad 802$

$802 \quad 849$

849898

$898 \quad 948$

$948 \quad 1004$

$1004 \quad 1049$

1049. 1103.5

$1103.5 \quad 1152.5$

$1152.5 \quad 1199$

$1199 \quad 1250$

$1250 \quad 1301.5$

$1302.5 \quad 1353$

$1353 \quad 1403$

$1403 \quad 450$

$1450 \quad 1496.5$

1496.51549 $\frac{\$}{\text { Total So Masn. Po }}$

11.96

11.70

6.09

10.10

21.54

22.98

13.79

14.43

14.27

13.63

14.27

8.02

4.19

14.75

13.79

14.19

13.06

12.74

12.82

11.83

15.83

15.51

15.67

15.51

14.55

18.30

15.35

15.83 GMCDATAREPORT \& 55

4.55 Page $161 / 189$ 
B. J. LOAGTER $\propto$.

HUNBLE ALASKA FROJECT

DRILL HOLS NO. 9 - Iron ABsays

\section{Comparite}

No.

c-91

$c-92$

C-93

C-9h

C-95

$c-96$

$c-97$

C-98

c-99

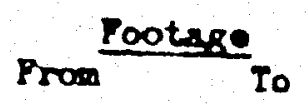

$1549 \quad 1602$

$1602 \quad 1653$

$1653 \quad 1706$

$1706 \quad 1751$

$1751 \quad 1799$

$2799 \quad 2553$

$1853 \quad 1901$

$1901 \quad 1949$

19492000

Hole bottaned 2000'.

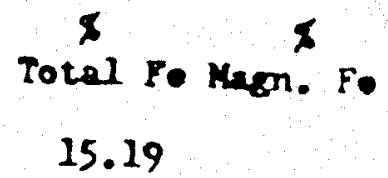

15.35

16.31

16.28

14.63

14.23

12.78

12.15

$16.15 \quad 10.19$

\section{saplo}

974

975

$\begin{array}{ll}1363 & 1373 \\ 1373 & 1380\end{array}$

$18.62 \quad 13.09$

$29.65 \quad 25.43$

GMC DATA REPORT 355

Pge $162 / 189$ 
E. Jo Lengyear Corpary

Humble Nlaska Eroject

DRILL TOLS NO. 98 Kagnetic 1ron deteralations made on Deris Tube Tester. Samples wero stage ground to pass 200 mon.

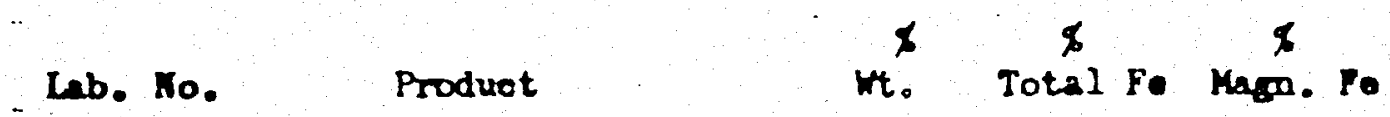

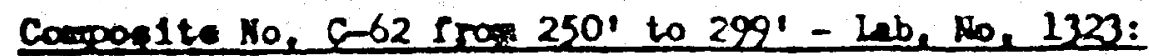

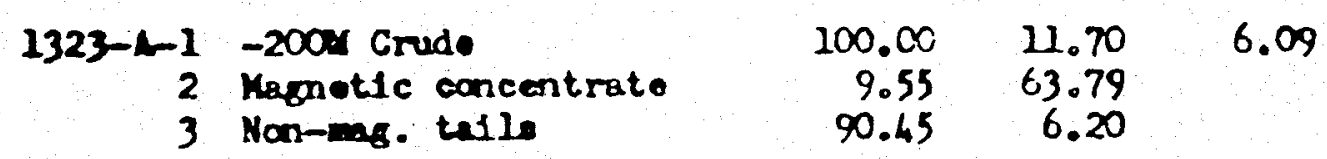

Cosposte to, C-70 Iran 650' to 697' - Lab, No, 13248

\begin{tabular}{|c|c|c|c|}
\hline $\begin{array}{r}132 x-1-1 \\
2 \\
3\end{array}$ & $\begin{array}{l}-200 \mathrm{~d} \text { Crade } \\
\text { Krametic concentrate } \\
\text { Mon-ms. talls }\end{array}$ & $\begin{array}{r}100.00 \\
12.00 \\
88.00\end{array}$ & $\begin{array}{r}14.27 \\
66.80 \\
7.11\end{array}$ \\
\hline
\end{tabular}

Cosposite Ho, C-99 Iron 1949' to 2000' - Lab, No, 13258

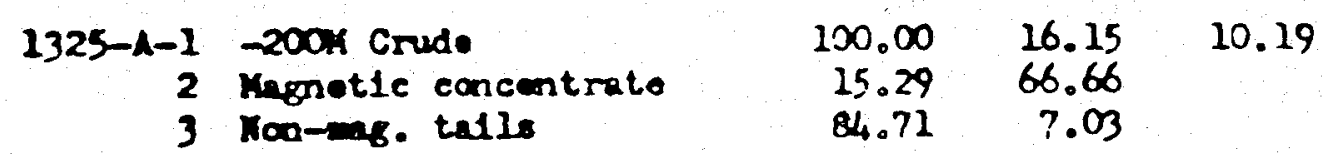

Saralo No, 274 fros 13631 to $1373^{\prime}$ - Lab, No, 13301

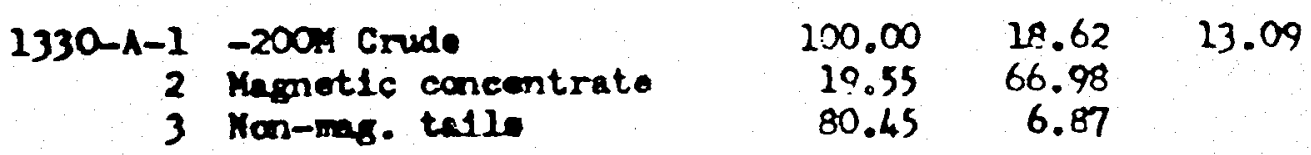

Sample No, $975^{\circ} \operatorname{ran} 13731$ to 13801 - Lab. No. 1331:

$\begin{array}{rlrrr}1331-A-1 & -200 \text { Crude } & 100.00 & 29.65 & 25.43 \\ 2 & \text { Kagmetic concentrate } & 38.43 & 66.18 & \\ 3 & \text { Mon } \rightarrow \text { 8. tailo } & 61.57 & 6.85 & \end{array}$

GMC DATA REPORT 355

Page $163 / 189$ 
DRILL HOLE NC. 9 - Coppor assay

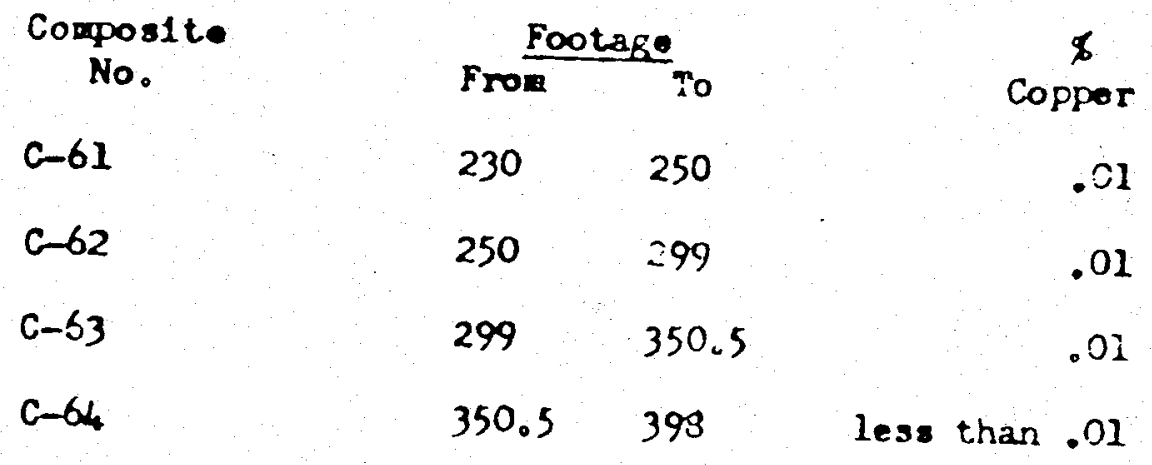

0
$\infty$
-1
0
0
-1

Semple

No.

831

832

833

834

835

892

893

89

895

896

897

898

899

900

901

902

903

\section{$593.5 \quad 603.5 \quad$ lese than .01}

$603.5 \quad 605$

608

611

621

738

748

738

748

755

760.5

755

70.5

773.5

770.5

$773.5-773.5$

$778.5 \quad 730.5$

$780.5 \quad 786.5$

$786.5 \quad 794$

$794 \quad 902$

802

812

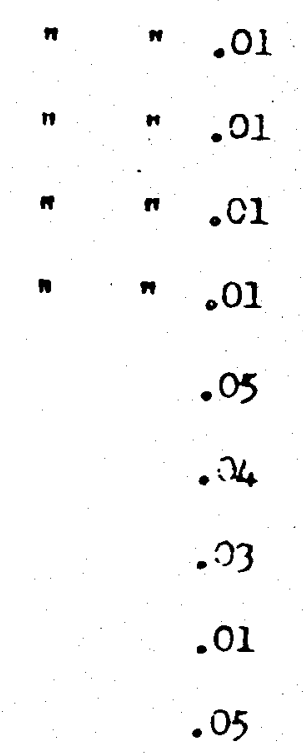

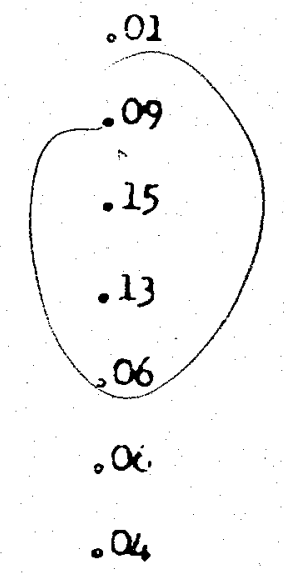

Continuod on Jhoot 2 


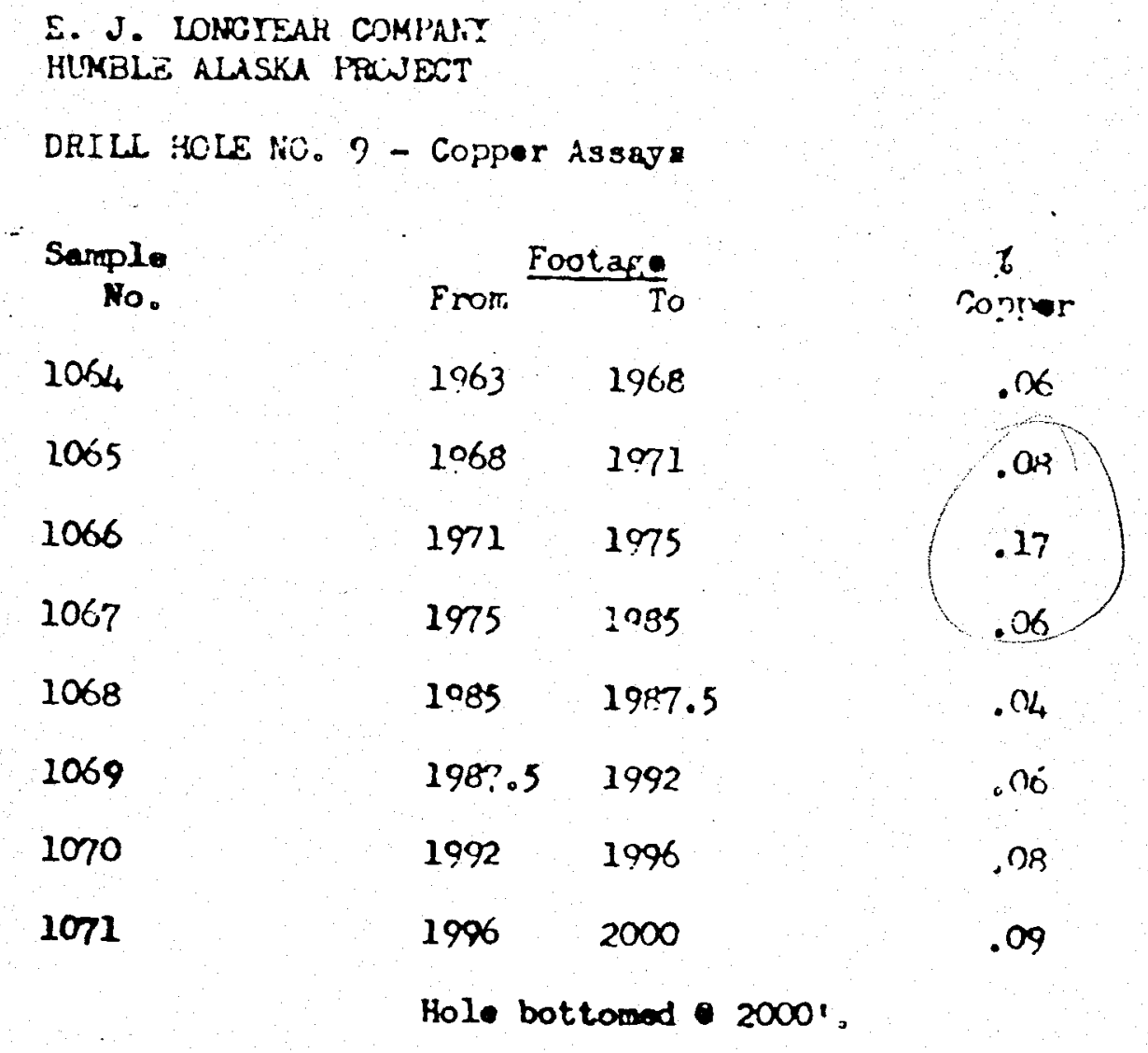

E. J. LONGTEAH COMPAP

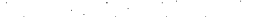

GMC DATA REPORT 355

Page $165 / 189$ 
E. J. LONGYEAR COMPANI

HUMBLE ALASKA PROJECT

DRILL HOLE NO. 9 - ZAInC As8458

$\begin{array}{ccccc}\begin{array}{c}\text { Samplo } \\ \text { No. }\end{array} & \begin{array}{c}\text { Footage } \\ \text { From }\end{array} & \text { To } & \begin{array}{c}\% \text { Zinc } \\ \text { (by Textor) }\end{array} & \begin{array}{c}\text { \% Zinc } \\ \text { (by Lerch) }\end{array} \\ 957 & 1260 & 1270 & .010 & .01 \\ 958 & 1270 & 1280 & .010 & .01 \\ 959 & 1280 & 1284 & .010 & .01 \\ 960 & 1284 & 1286 & .025 & .01\end{array}$


8. J. LUGTKUR DMFARY

HUCBLE ALASKa PLOJELT

DRILL HOLS 10.20 - havar

\section{Compostte}

$\cos \sqrt{ }$

$1+8$

$c+9$

c-50

$c-51$

c-52

C-53

Sarplo

536

549

556

500

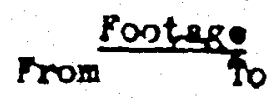

$201 \quad 250$

$250 \quad 303.5$

$303.5 \quad 350$

$350 \quad 396$

$396 \quad 450$

450

495

495

532

Hols bottond 532 '
$\frac{x}{T o t a l}$ Te Maga. $\mathrm{Fa}$

$15.29 \quad 8.73$

14.07

4.71

14.87

13.27

$13.67 \quad 6.29$

13.91

$\begin{array}{llll}30385 & 311.5 & 44.79 & 7.71 \\ 362 & 365 & 15.59 & 10.25 \\ 406 & 416 & 4.55 & 8.55 \\ 475 & 479 & 15.91 & 7.60\end{array}$

GMC DATA REPORT $\div 55$

Page $167 / 189$ 


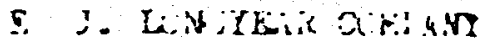

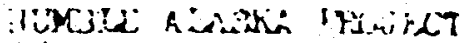

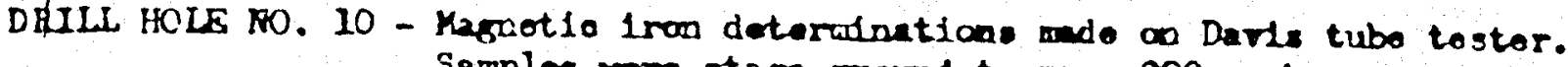
Samplos were stage ground to pase 200 mas.

Lab. No.

Product

Ht. Total Fe Magn. Fo

SAMPLB NO, 536 - ITOM 303.51 to 311.51 - Lab, No, 13238

\begin{tabular}{|c|c|}
\hline $\begin{array}{r}313-1-1 \\
2 \\
3\end{array}$ & 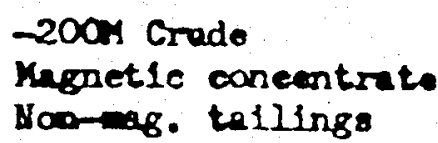 \\
\hline
\end{tabular}

SAKPLE NO, 549 - from $362^{\prime}$ to $365^{\prime}-$ Lab, no, $23 u_{4}$

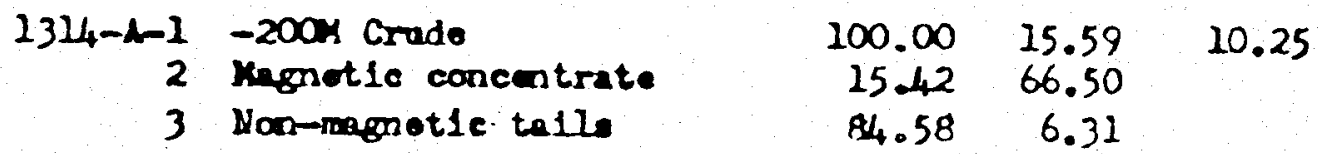

SAMPLS N0. 556 - Irom $406 \cdot$ to 4161 - Labe No, $1715:$

$\begin{array}{rlrrr}1315-1-1 & -2001 \text { Crude } & 100.00 & 14.55 & 8.55 \\ 2 & \text { Nonotic ooneantrato } & 12.74 & 67.14 & \\ 3 & \text { Non-eognet10 taile } & 87.26 & 6.87 & \end{array}$

SAKPLE N0, $580-\operatorname{Iram} 4751$ to $479^{1}-1$ be, No, 13161

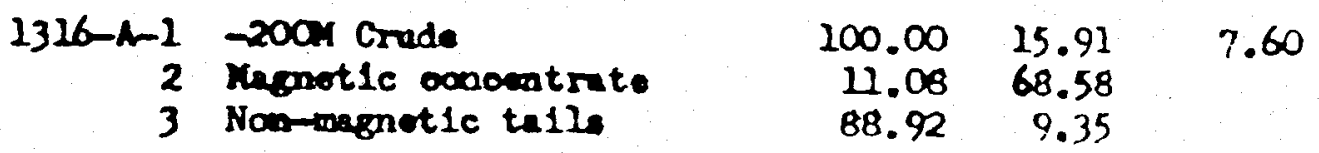

COMPOSITE NO. C-47 Pron $201^{\prime}$ to $250^{\circ}$ - Lab, No, 1326 ,

$\begin{array}{rlrrr}1326-1-1 & -200 \times \text { Crude } & 100.00 & 15.19 & 3.73 \\ 2 & \text { Nometic concentrate } & 13.00 & 67.14 & \\ 3 & \text { Noomag. talls } & 87.00 & 7.43 & \end{array}$

COMPOSITS NO. C-52 Prom 450' to 495' - Lab, No, 13271

$\begin{array}{rlrrr}1327-1-1 & -200 \times \text { crude } & 100.00 & 13.67 & 6.29 \\ 2 & \text { Nopnetic concentrate } & 9.41 & 66.80 & \\ 3 & \text { Nosmae, tailo } & 90.59 & 8.15 & \end{array}$

GMC DATA REPORT 355

Page $168 / 189$ 


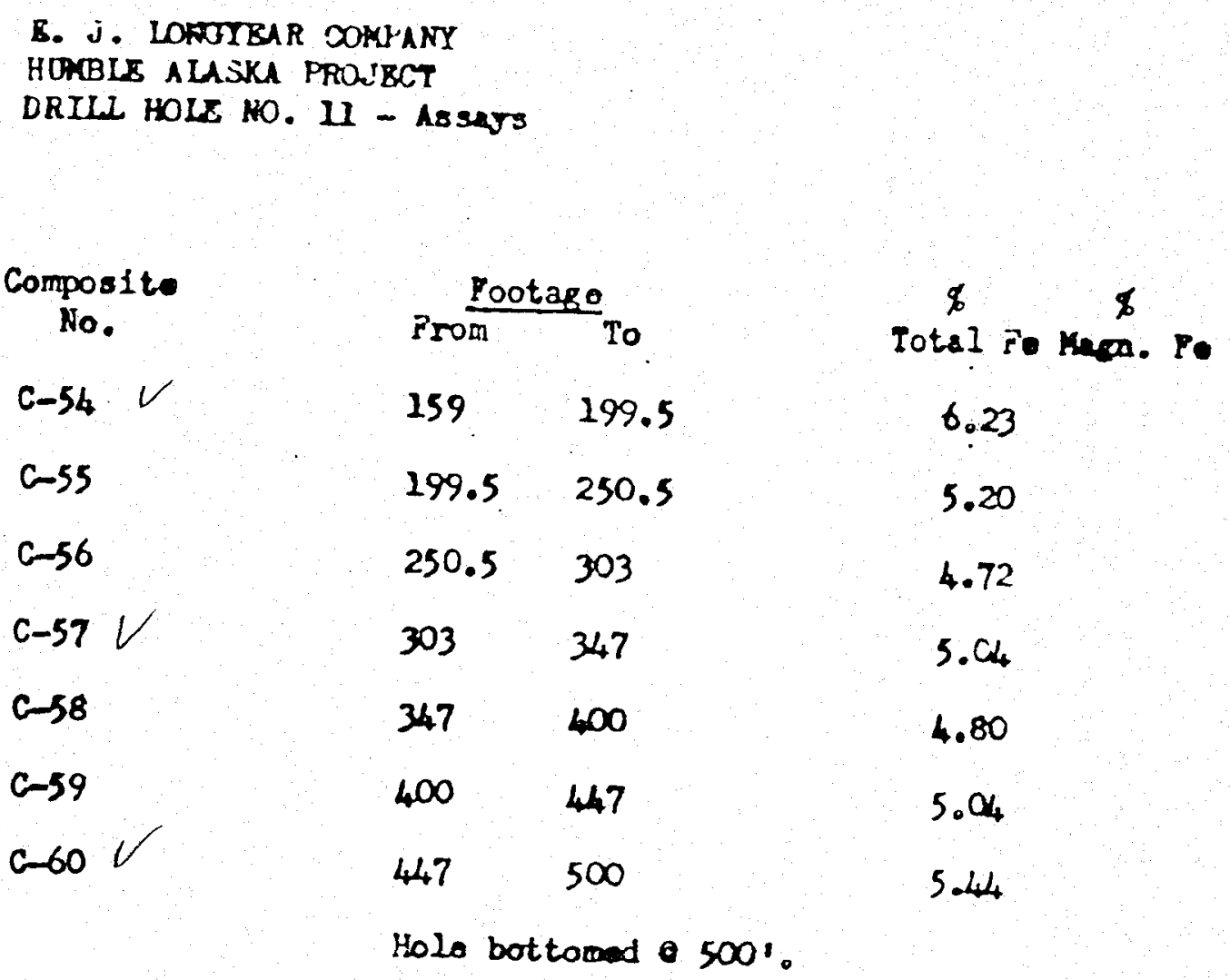


Copposite

No.

C-71

$c-72$

$\mathrm{c}-73 \mathrm{~V}$

$c-100$

$c-101$

$c-102$

C-103

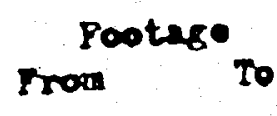

254

301

349

401

451

500

552
301

12.85

$$
349
$$

12.33

$$
401
$$

12.97

$451 \quad 11.91$

$500 \quad 12.63$

$552 \quad 11.90$

600

11.83

5.41

Hole bottaned $600^{\prime}$.

\begin{tabular}{lll}
$\frac{3 \text { pla }}{\text { No }}$ & \\
\hline 855 & 280 & 284 \\
856 & 284 & 286 \\
857 & 286 & 288 \\
858 & 288 & 292 \\
874 & 337 & 339 \\
875 & 339 & 346.5 \\
883 & 363 & 373
\end{tabular}

$<.01$

$<.01$

$<.01$

$<.01$

$<.01$

1.77 Nม1

$<.01$

1.80

N11

$<.01$

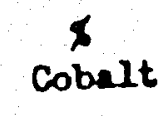


8. J. LOMGTEAR COMPANT

HURBLE ALASKA PPOJECT DRILl HOLE \%. 122 Mapnotic Iron determinationo made on Daris tubo toster.
Semples wore stage ground to pass 200 mesh.
La. No.
Product
Wt. Total Po Magn. Fo

COMPOSITE NO. C.1 from 254' to $301^{\prime}$ - Lab, Yo. 1328:
1328-A-1 -200A Crude
2 Magnotic concentrate
3 Nos-m. tallo
$100.00 \quad 11.85$
$10.58 \quad 64.66$
6.84
$89.42 \quad 5.60$

COMPOSITB N0. C-103 rrom 5521 to $6001-$ Lab, No, 1329 :

$\begin{array}{rlrrr}1329-1-1 & -200 \text { C Crade } & 100.00 & 11.83 & 5.41 \\ 2 & \text { Magnet1e concentrate } & 8.70 & 62.19 & \\ 3 & \text { Non-ma8. ta1le } & 91.30 & 7.03 & \end{array}$

GMC DATA REPORT 355 
E. I. LONGTBAR COMFAMT

HUMBIE A LASKA TTOJJET

DRILL HOLE NO. 131 Iran assay
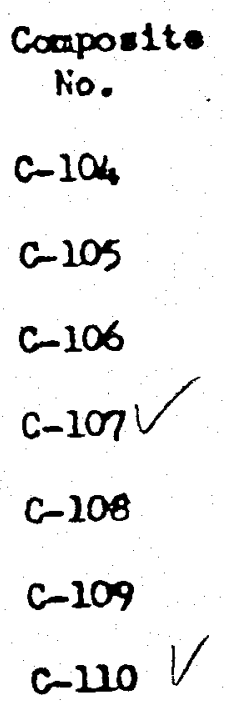

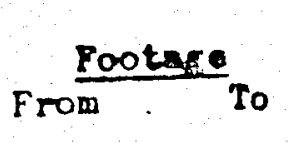

$332 \quad 350$

$350 \quad 400$

$400 \quad 449$

$449 \quad 497.5$

$497.5 \quad 550$

550

604

604

668

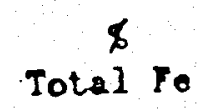

4.76

8.72

9.67

7.97

6.64

6.60

5.96

Plolo bottonad 6681 .

GMC DATA REPORT 355

Page $172 / 189$ 
B. J. LOKGYEAR COMPANY

HUNDELS ALASKA PROJBCT

DRTLC HOLE NO. 14 - ITON aseays.

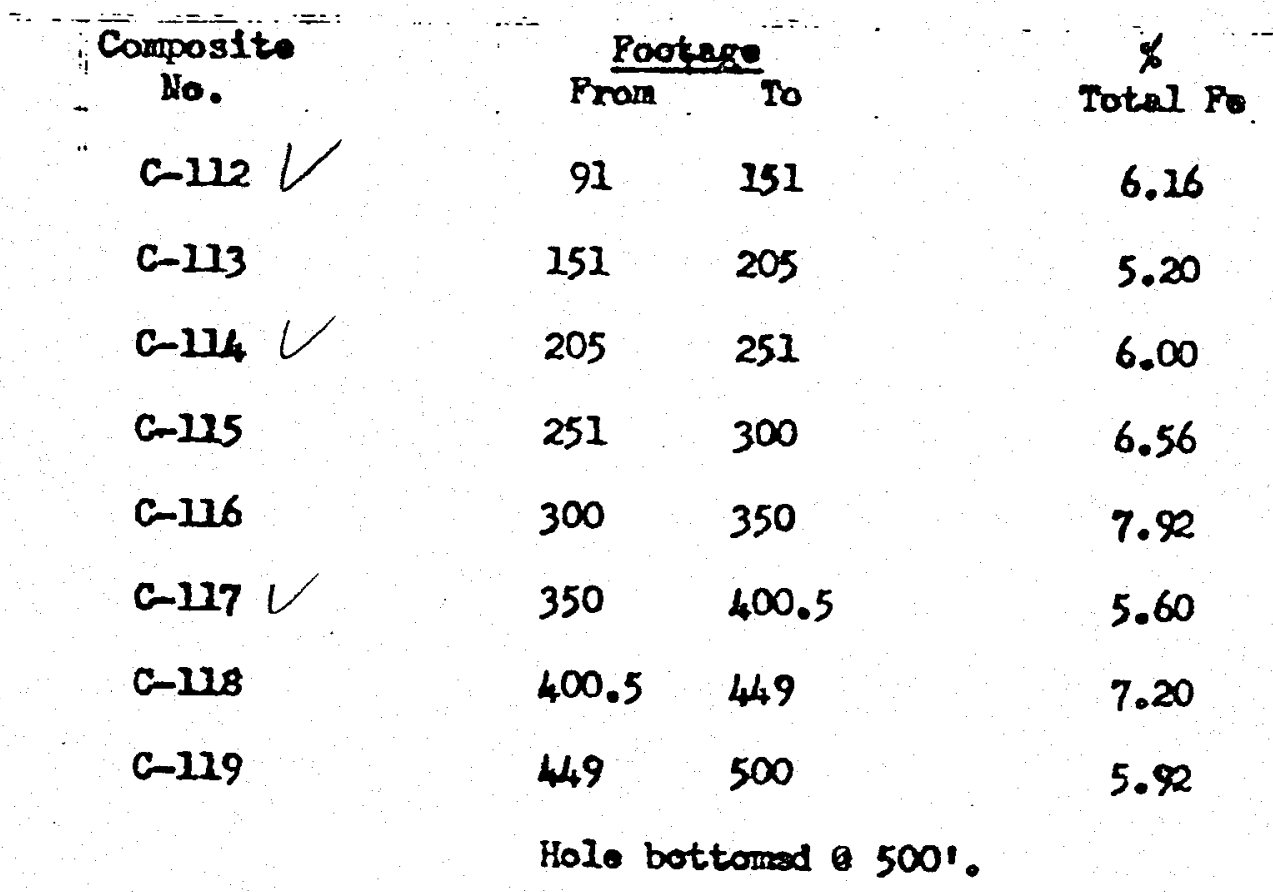


B. J. LONGYEAR COMPANY

HUMBLE ALASKA PROJBCT

DRILC HOIE NO. 15 - Iron assays.

$\begin{array}{cccc}\begin{array}{c}\text { Composito } \\ \text { No. }\end{array} \text { Frootage } & \begin{array}{c}\not \\ \text { To }\end{array} & \text { Total Pa } \\ \text { C-120 } & 470 & 500 & 5.44 \\ \text { C-121 } & 500 & 549 & 4.96 \\ \text { C-122 } & 549 & 637 & 5.62\end{array}$

Hole bottomed $637 !$

\section{DAVIS TUBE TESTS @ -200 Mesh}
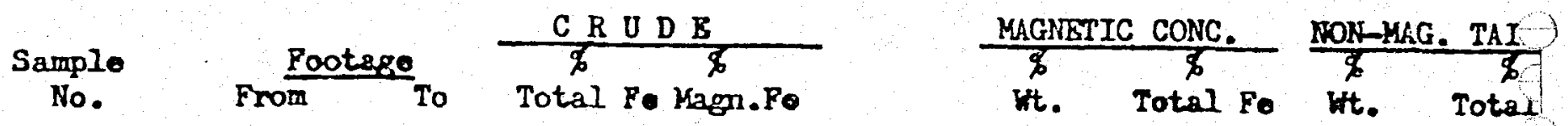

1324

614

618

5.96

1.17

1.8

63.7198 .16

1326

622

632

$8.00 \quad 1.03$

3.22

$32.02(1) 96.78$

7.)

(1) Chamlst's nota: $\mathrm{MIO}_{2}$ present in large ampunt".)

GMC DATA REPORT 355 


\begin{tabular}{|c|c|c|}
\hline DRILL HOLX NO. $17 \mathrm{t}$ & Iron assaro & \\
\hline $\begin{array}{l}\text { Composito } \\
\text { No. }\end{array}$ & Prom $\frac{\text { Footsose }}{\text { To }}$ & Total Fe Kagn. Po \\
\hline$C-111$ & $460 \quad 530$ & 11.99 \\
\hline
\end{tabular}

\section{Saple \\ No.}

$\begin{array}{llll}H-1 & 460 & 485 & 10.00 \\ 1-4 & 495 & 500 & 0.43 \\ 7-9 & 520 & 530 & 12.83\end{array}$

Mecnotic iron determination by Derle tube teater e-200M orinds

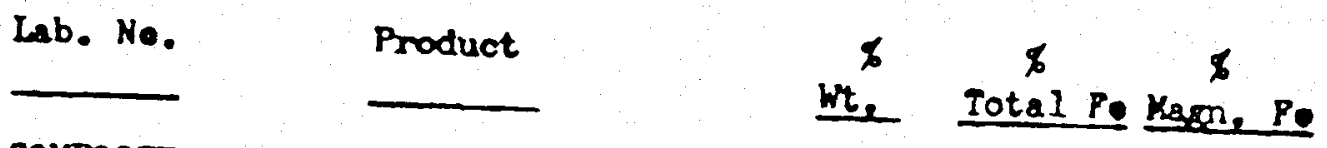

CORPOSTTE NO. C-112 PrOm 4601 to 5301 - Lab, No, 1335 :

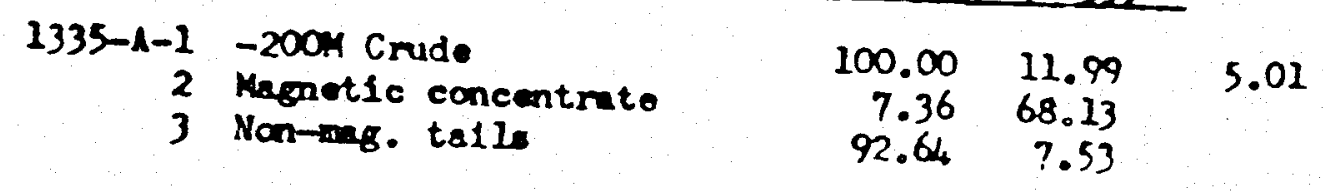

GMC DATA REPORT 355 


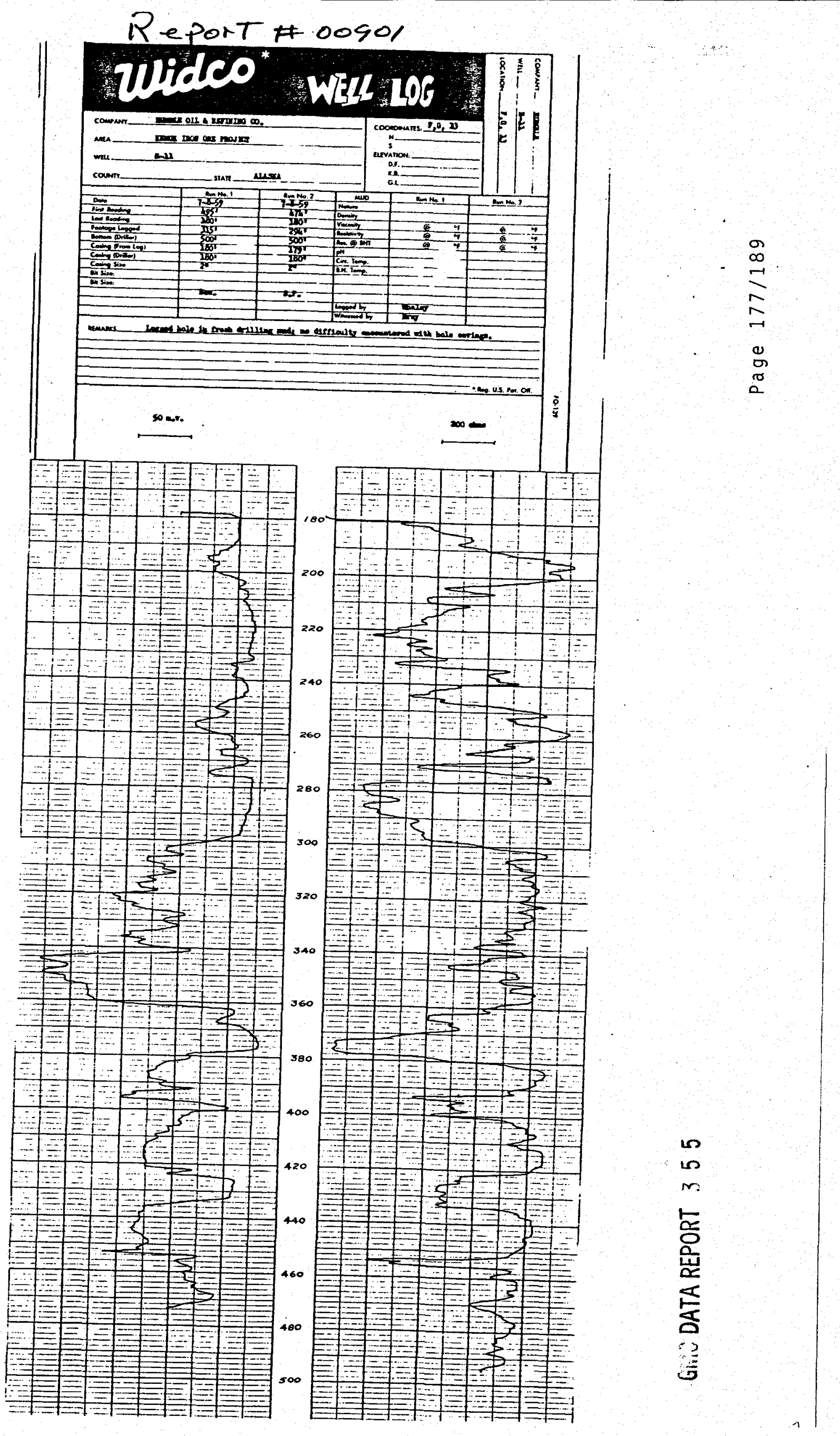




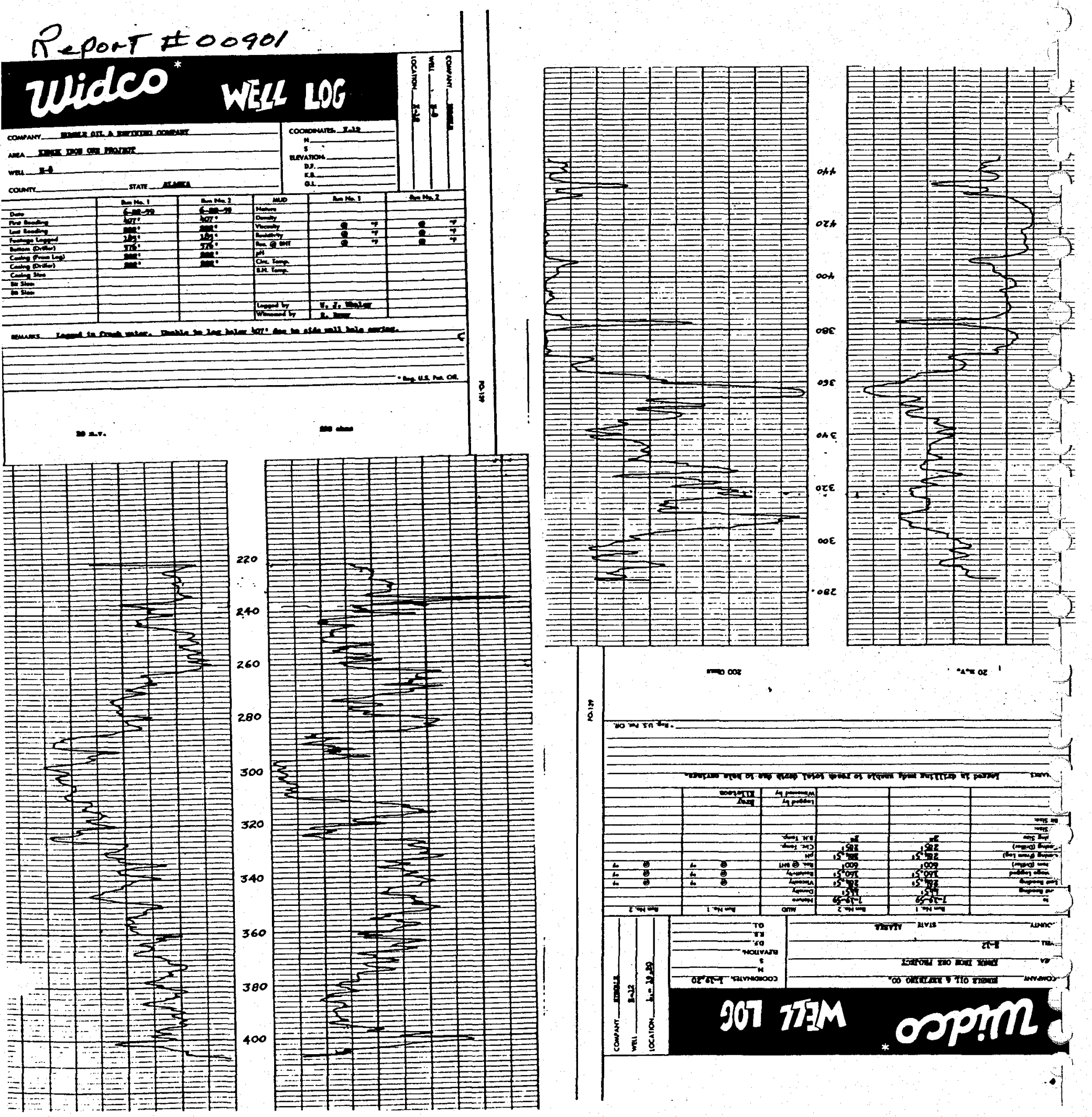



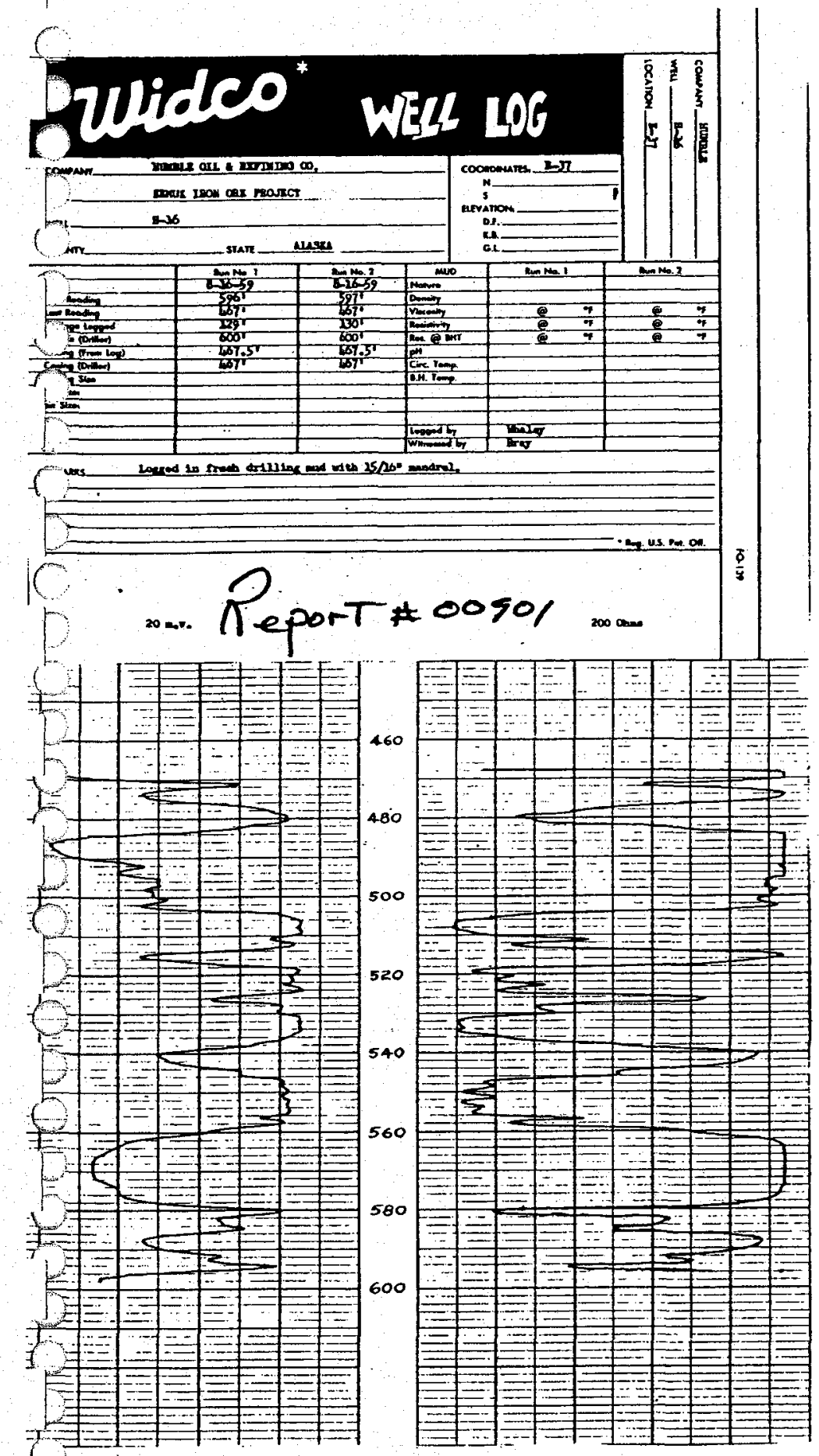

$68 \mathrm{~L} / 08 \mathrm{~L} 26 \mathrm{ed}$

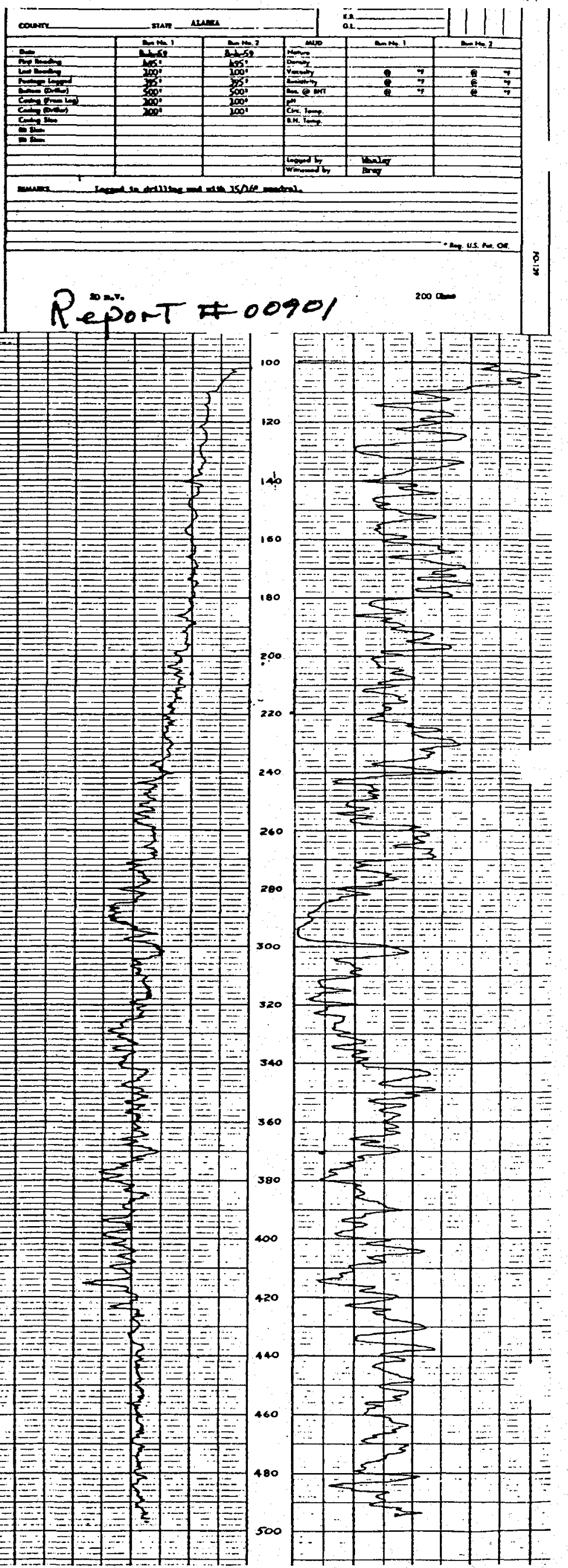




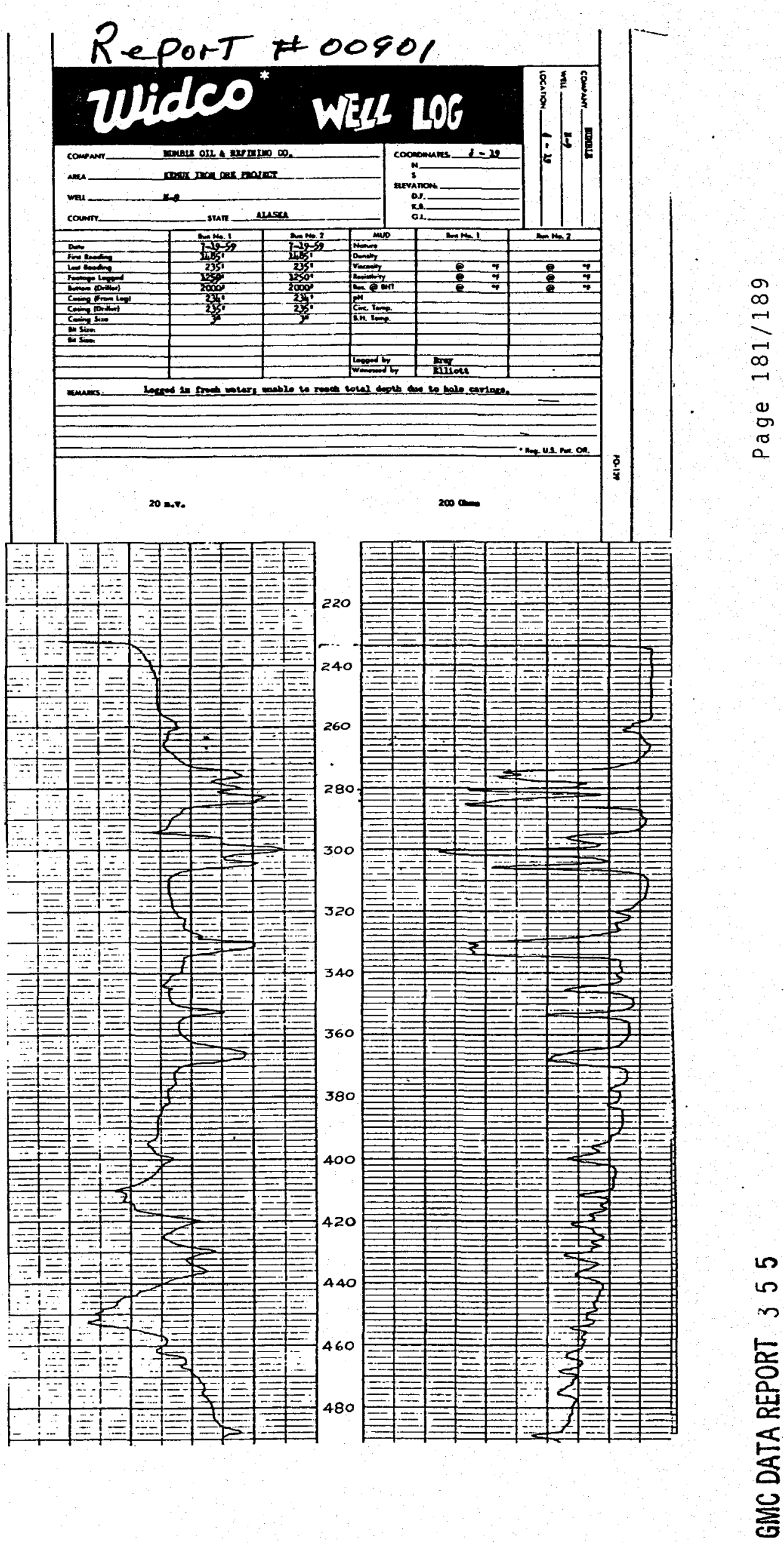




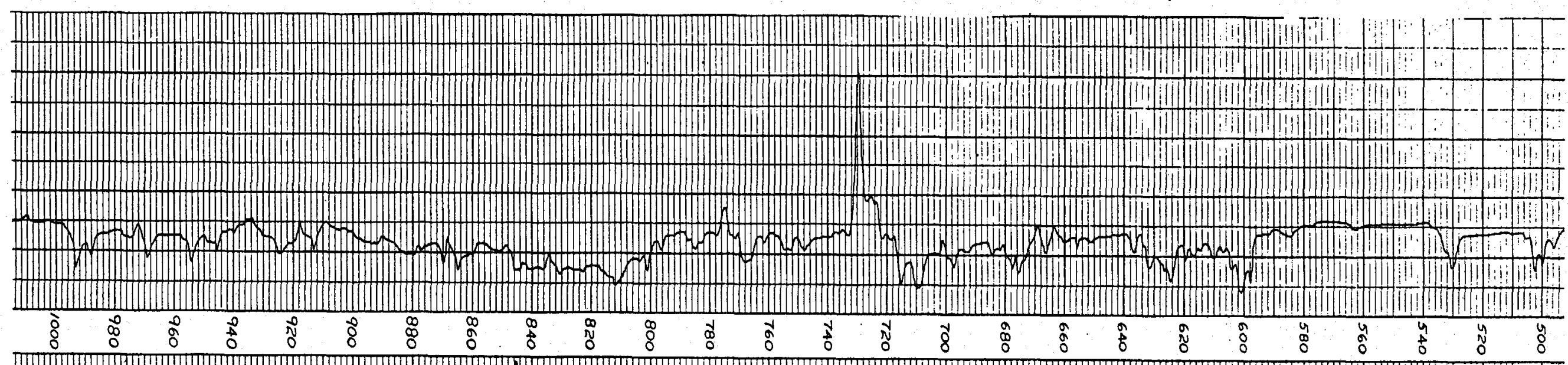
T.m. ¿ (1) |m, ¿ 1. ¿

\section{GMC DATA REPORT 355}

Page $182 / 189$

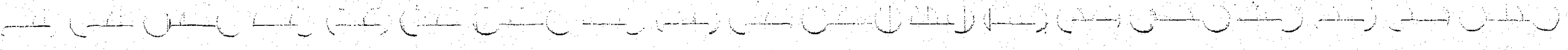




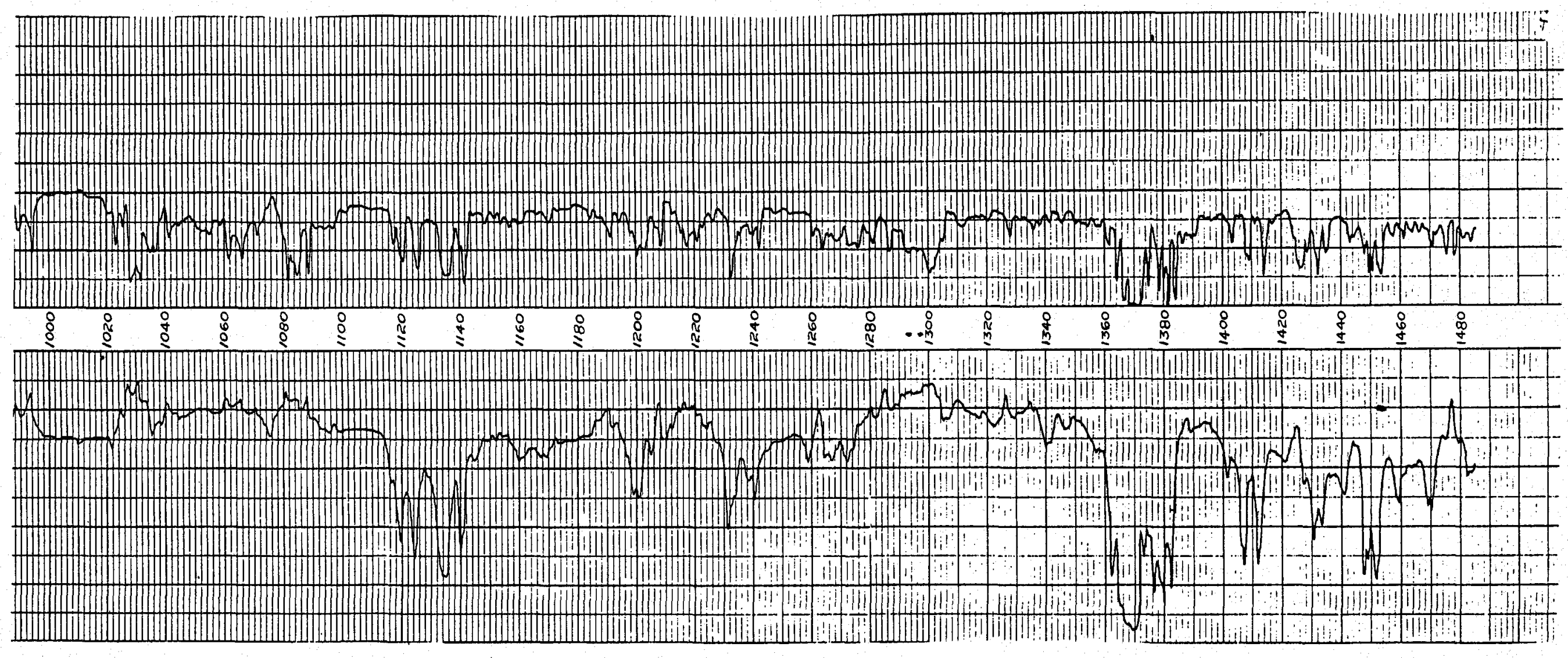

\section{GMC UAIA REPORT I 55}




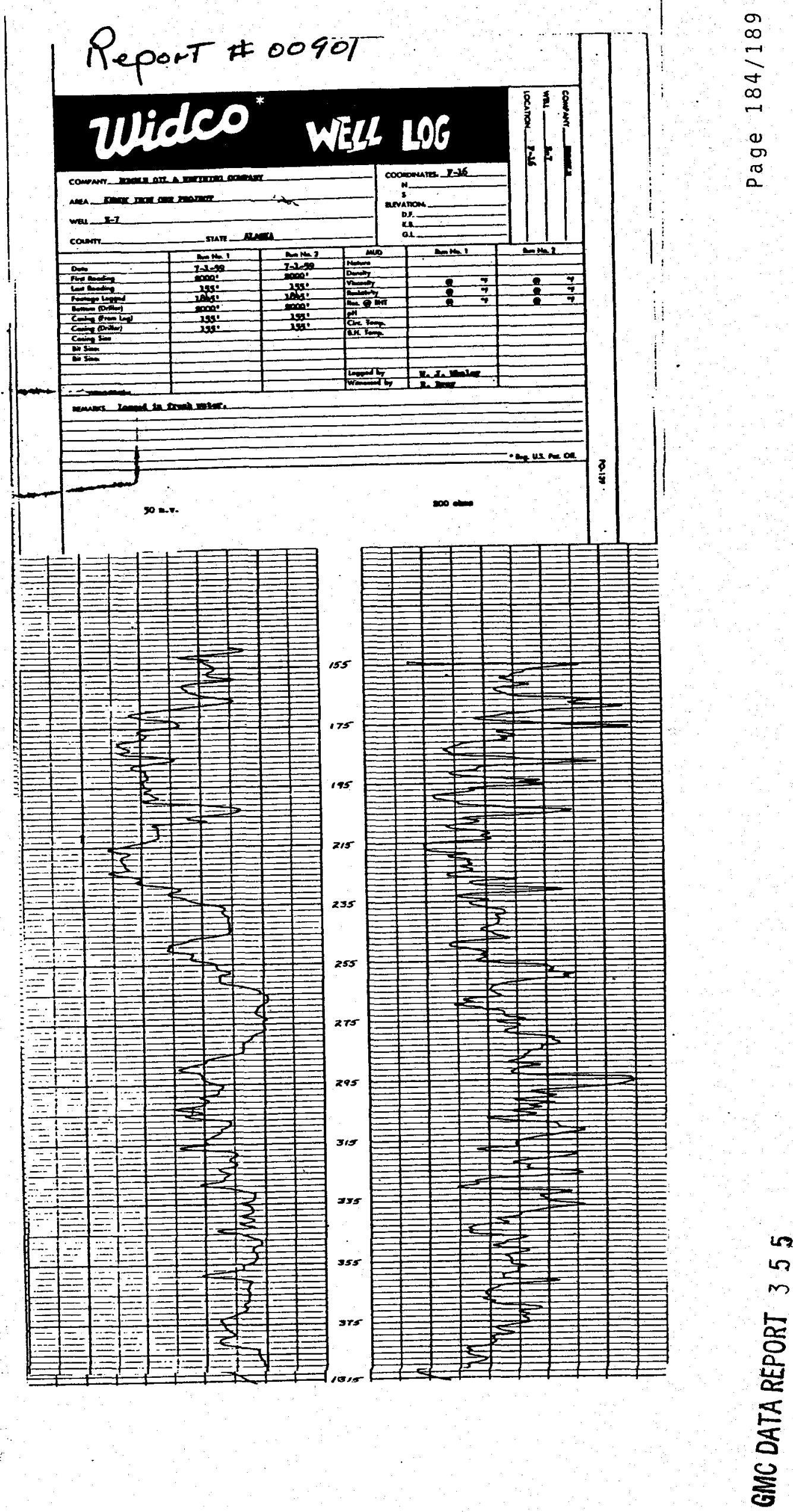




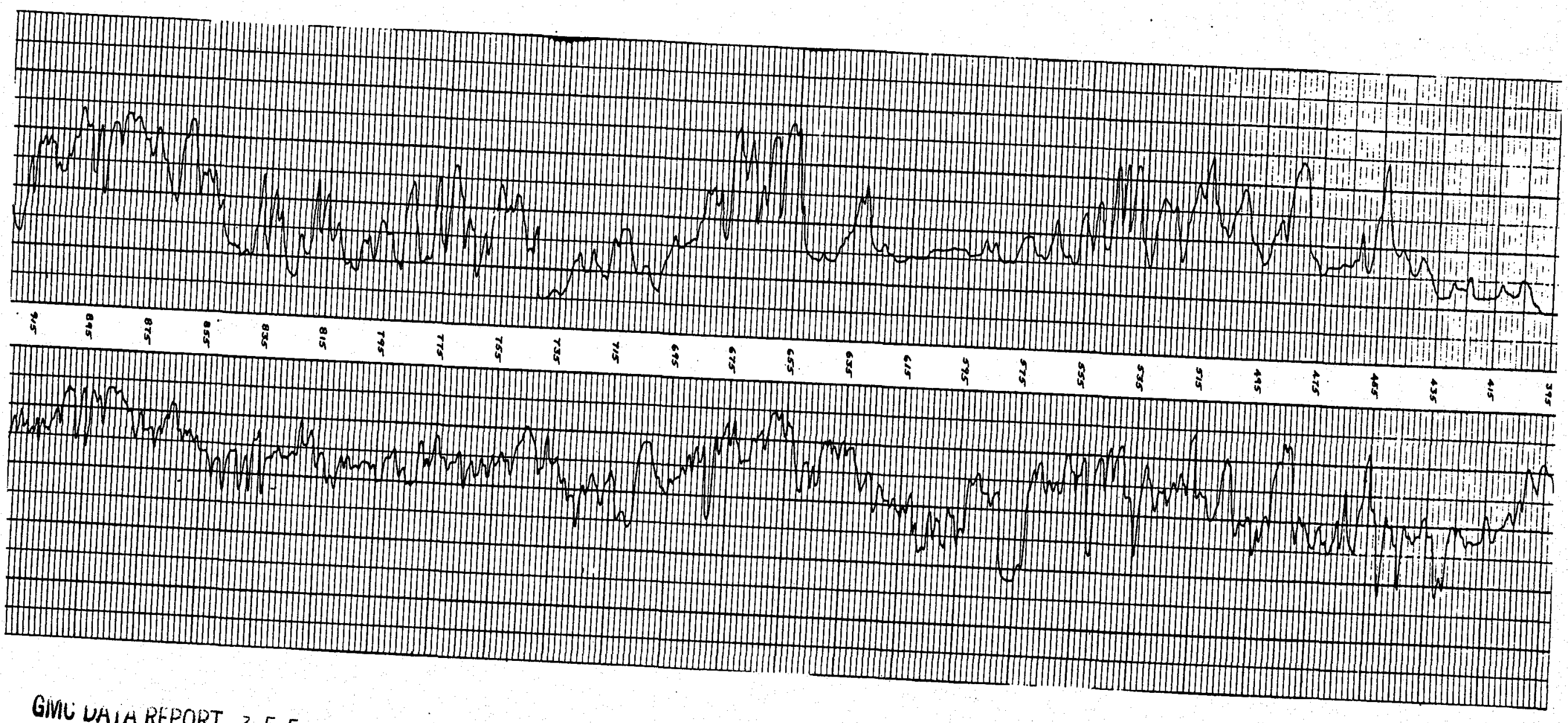

Page $185 / 189$ 


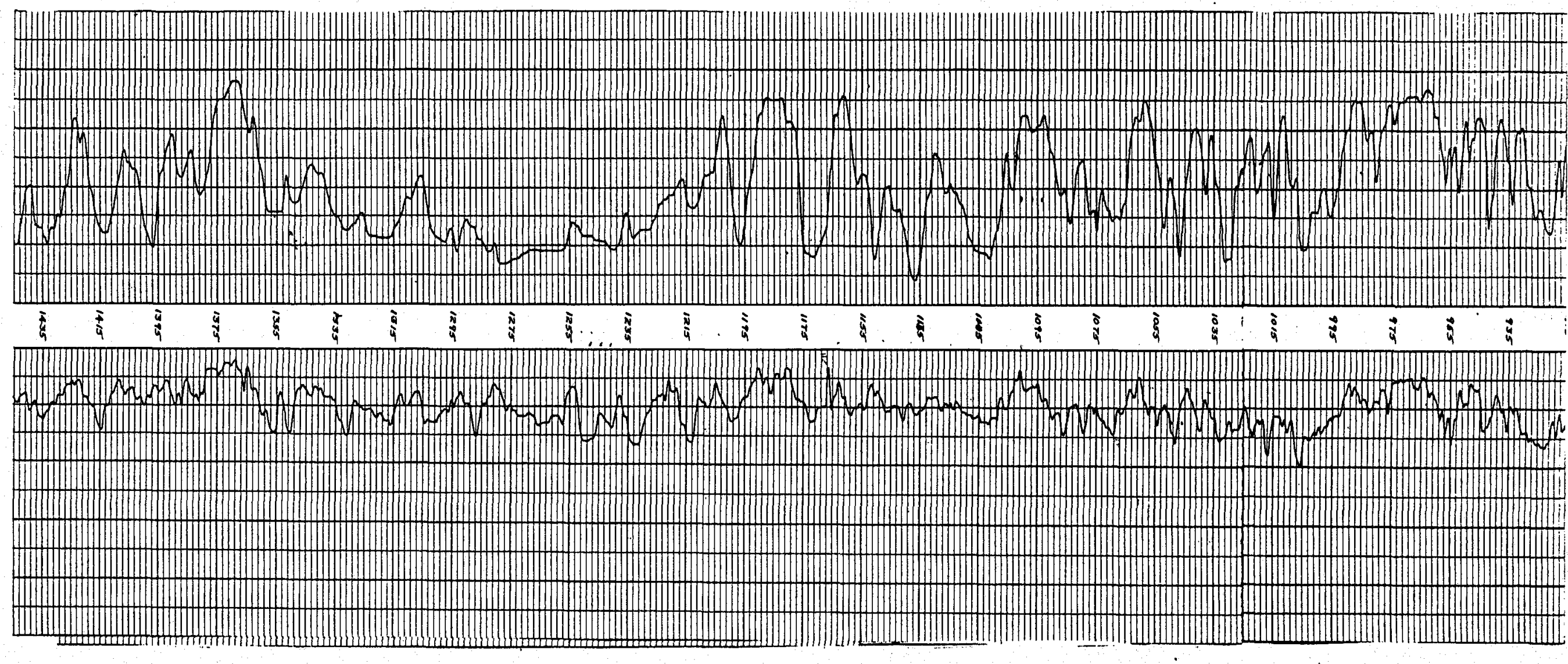

GMC DATA REPORT I 55

Page $186 / 189$ 


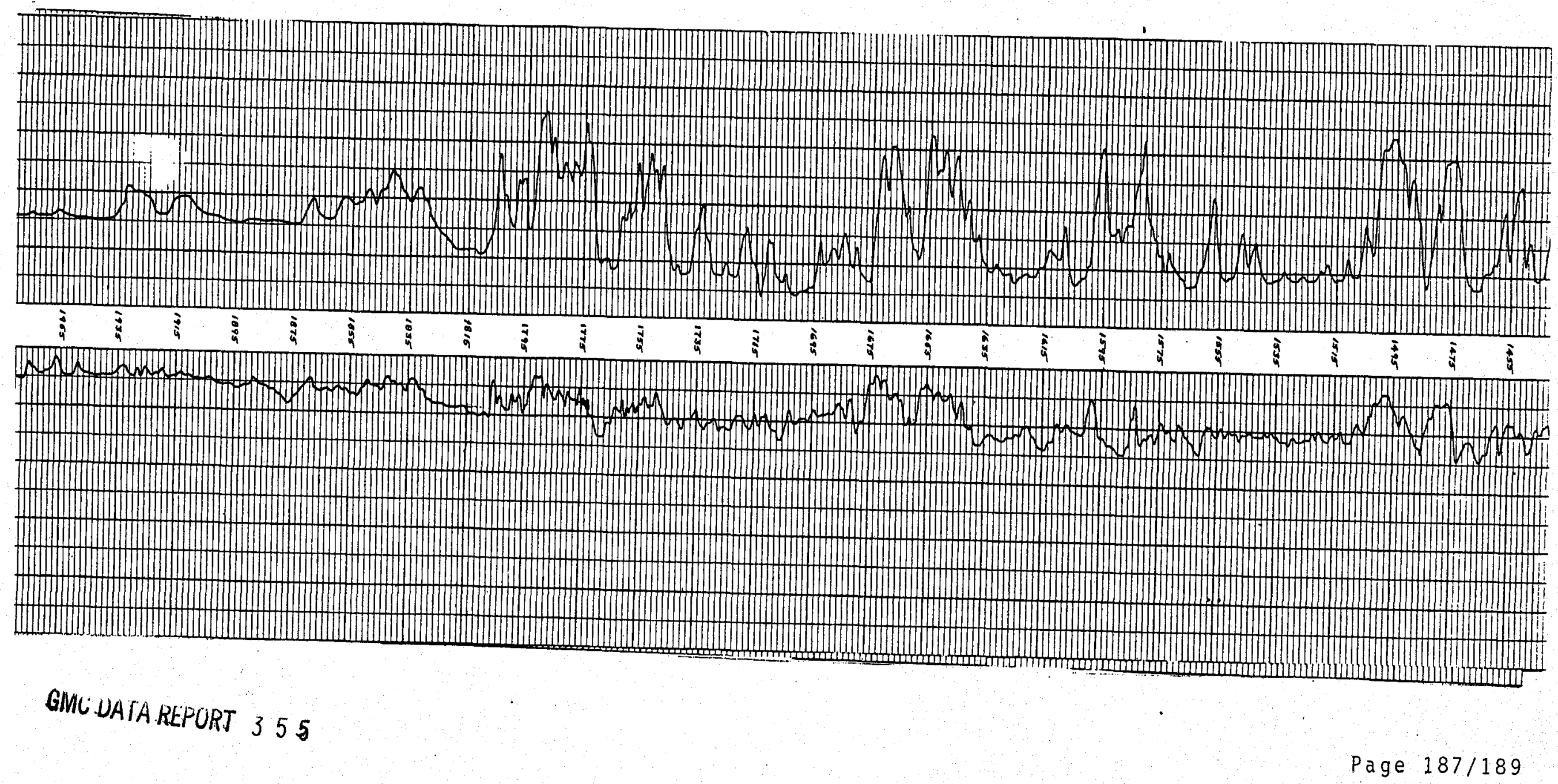




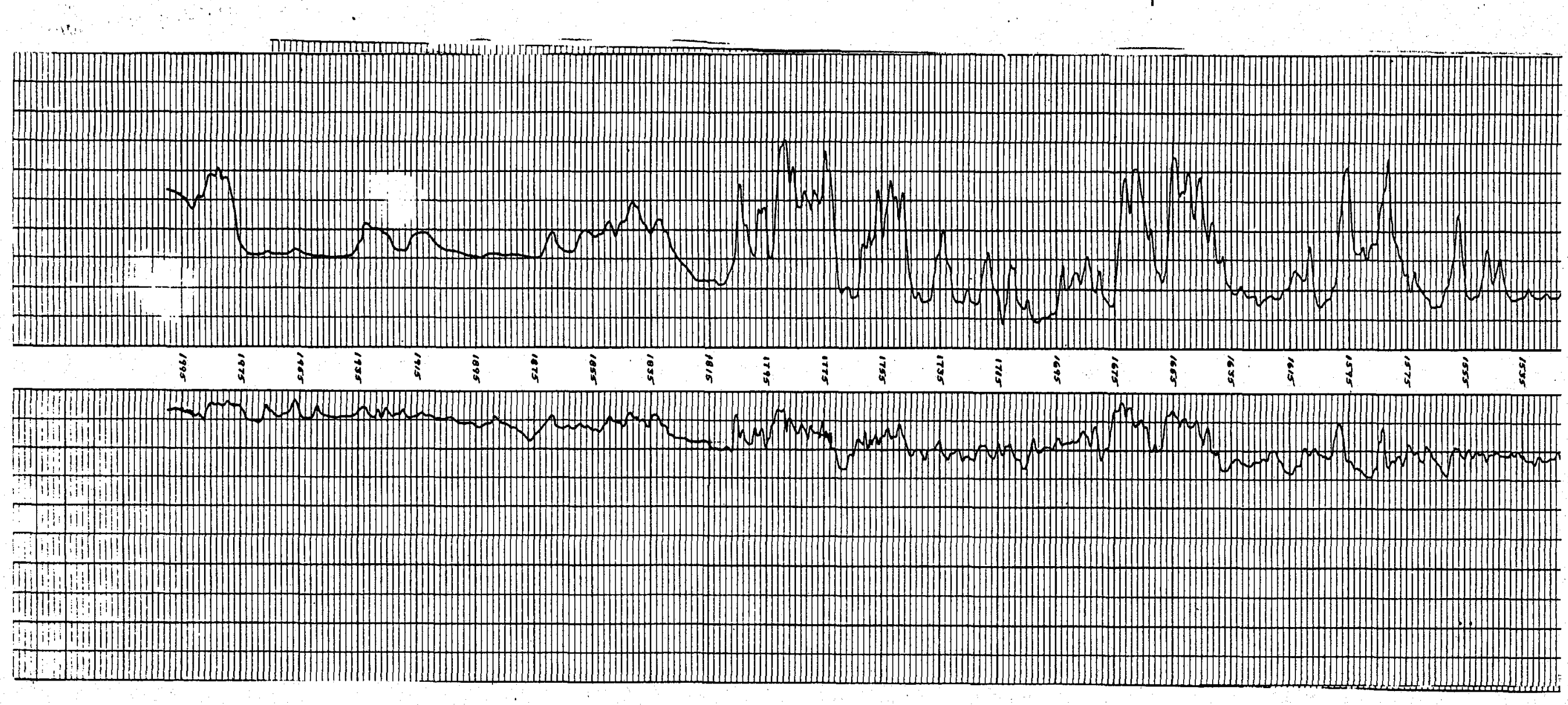

\section{GMC DATA REPORT 355}




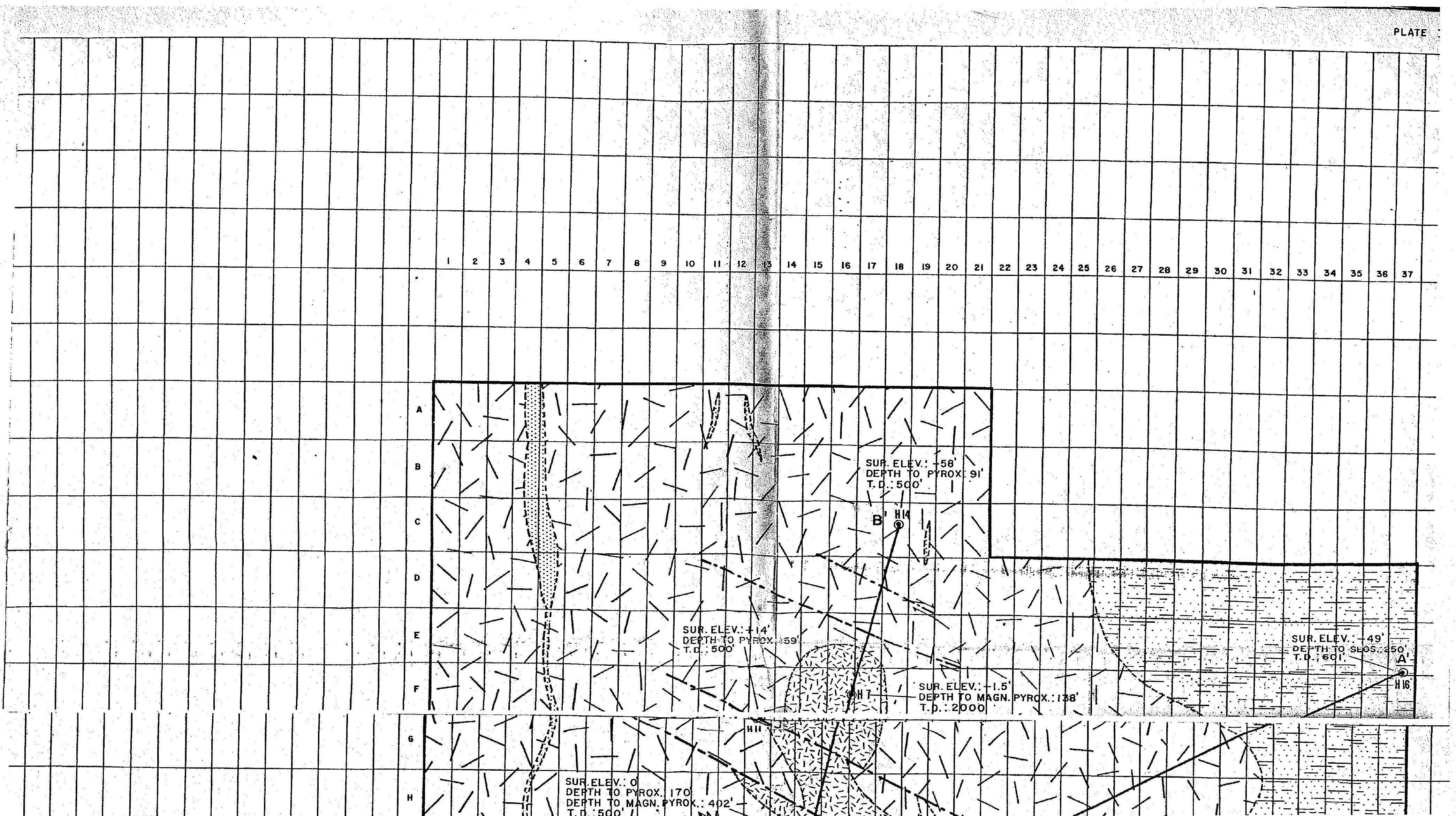



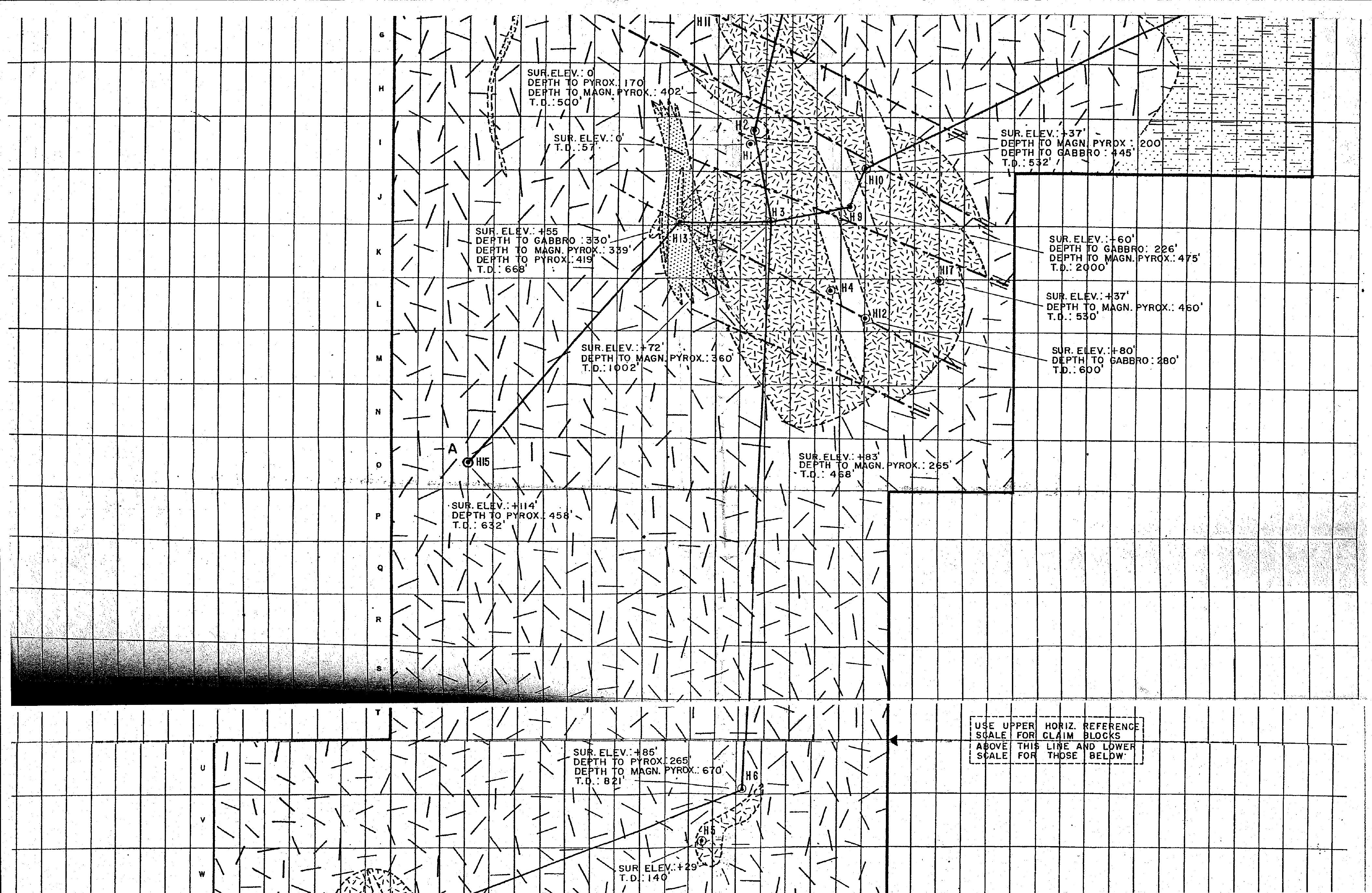

Tu

的 
